Nilce Vieira Campos Ferreira

Neil Franco

Oresta López Pérez

(Organizadores)

\title{
História da Educação, \\ Ensino e Itinerários Formativos nas Regiões Centro-Oeste e Norte Brasileiras
}

Sustentável
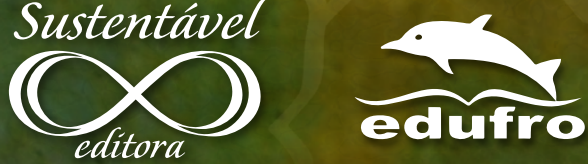


\section{História da Educação, \\ Ensino e Itinerários Formativos nas Regiões Centro-Oeste e Norte Brasileiras}




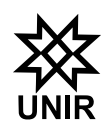

Fundação Universidade Federal de Rondônia

Reitor

Ari Miguel Teixeira Ott

Vice-Reitor

José Juliano Cedaro

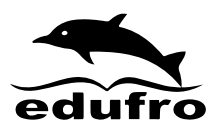

Editora da Universidade Federal de Rondônia

\section{Conselho Editorial}

\section{Membros}

Lou-Ann Kleppa (Letras UNIR)

Ariana Boaventura Pereira (Libras UNIR)

Ricardo Gilson da Costa Silva (Georafia UNIR)

Marli Lúcia Tonatto Zibetti (Psicologia UNIR)

Márcio Secco (Filosofia UNIR)

Pedro Ivo Silveira Andretta (Biblioteconomia UNIR)

Carlos Alexandre Barros Trubiliano (Intercultural UNIR)

Gean Carla Silva Sganderla (Biologia UNIR)

Eliane Gemaque Gomes Barros (Biblioteca UNIR)

Xênia de Castro Barbosa (História/ IFRO)

Leandro Soares Moreira Dill (FAPERO) 
Nilce Vieira Campos Ferreira

Neil Franco

Oresta López Pérez

(Organizadores)

\section{História da Educação, \\ Ensino e Itinerários Formativos nas Regiões Centro-Oeste e Norte Brasileiras}

1a Edição
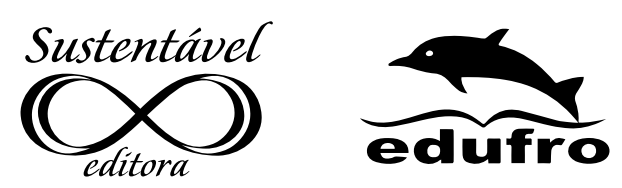

Porto Velho-RO

2020 
Dados Internacionais de Catalogação na Fonte

H673 História da educação, ensino e itinerários formativos nas regiões Centro - Oeste e Norte brasileiras [recurso eletrônico] / Nilce Vieira Campos Ferreira, Neil Franco, Oresta López Pérez, organizadores. - 1. ed. - Cuiabá: Editora Sustentável; Porto Velho: EDUFRO, 2020.

312 p. : il. color.

Vários autores.

ISBN: 978-65-87539-03-4 (Edufro).

ISBN: 978-65-87418-02-5 (Editora Sustentável)

1. Educação - História. 2. História da educação. 3. Prática pedagógica. 4. Ensino - Centro-Oeste brasileiro. 5. Ensino - . I. Ferreira, Nilce Vieira Campos. II. Franco, Neil. III. López Pérez, Oresta.

CDU 37(811+817)(091)

Ficha Catalográfica elaborada pelo Bibliotecário Jordan Antonio de Souza - CRB1/2099

\author{
Produção editorial I Editora Sustentável \\ Edição e design gráfico | Téo de Miranda \\ Revisão e normalização । Josemir Almeida Barros \\ Jorge Lago Fonseca \\ Nilce Vieira Campos Ferreira
}

Diagramação | Editora Sustentável

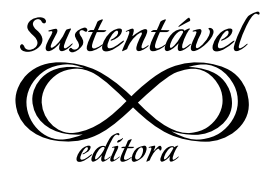

Editora Sustentável www.editorasustentavel.com.br

Fone: + 55 (65) 98159-9395

editorasustentavel@gmail.com

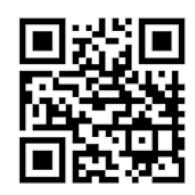

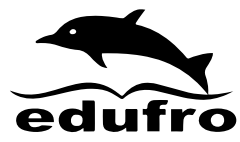

Edufro - Editora da Universidade

Federal de Rondônia

BR 364, Km 9,5, Campus Unir 76801-059 - Porto Velho - RO

Tel.: (69) 2182-2175

www.edufro.unir.br

edufro@unir.br

Editora filiada

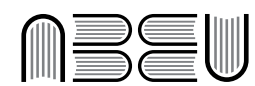

Associação Brasileira

das Editoras Universitárias 


\section{AGRADECIMENTOS}

Às pesquisadoras e pesquisadores das Regióes Centro-Oeste e Norte, cujos textos provenientes de suas atividades de ensino, de pesquisa, de extensão, compóem um vasto cabedal de conhecimentos que precisa ser difundido.

Ao Conselho Nacional de Desenvolvimento Científico e Tecnológico CNPq e à Coordenação de Aperfeiçoamento de Pessoal de Nível Superior - CAPES, pelo financiamento para o desenvolvimento de nossas pesquisas, seja em forma de fomento aos bolsistas de iniciação científica, nos cursos de Mestrado, Doutorado ou Pós-doutorado, seja no fomento a projetos de investigação, eventos educacionais e outros, pois acreditamos que sem investimento não se faz pesquisa que transforma, que muda, que propicia desenvolvimento ao Brasil.

A todas e todos que acreditam, como nós, em uma educação mais justa e equânime, afinal é preciso seguir rumo ao conhecimento do Centro-Oeste e do Norte brasileiros, e muito embora não queiramos significar, como nos lembrou o poeta, pois também temos a convicção de que significar pode limitar a imaginação, ainda assim nos questionamos se "[...] tudo que nos livros eu aprendesse, nas fontes eu aprendera. O saber não vem das fontes?". (BARROS, 2010, p. $483^{1}$ ).

1 BARROS, Manoel de. Poesia completa. São Paulo, Leya, 2010. 


\title{
PREFÁCIO
}

\section{Por una memoria viva de la historia de la educación}

\author{
Si bien todo proceso de construcción de memorias \\ se inscribe en una representación del tiempo y del espacio, \\ estas representaciones $-\mathrm{y}$, en consecuencia, \\ la propia noción de qué es pasado y qué es presente- \\ son culturalmente variables e históricamente construidas. \\ $\mathrm{Y}$ esto incluye, por supuesto, las propias categorías de \\ análisis utilizadas \\ por investigadores y analistas del tema. \\ Elizabeth Jelin, 2002 ${ }^{1}$.
}

Quiero iniciar agradeciendo la oportunidad de ofrecer unas reflexiones para acompañar la lectura de este libro colectivo, del que me honra en ser parte. Esto no sería posible si no hubiera tenido interlocución en calidad de par académico de proyecto internacional, con el valioso equipo de investigación de la Dra. Nilce Vieira Campos. En las reuniones científicas organizadas por ella, tuve acceso a espacios privilegiados de intercambio dialógico de miradas y de proyectos entre México y Brasil.

La solidaridad entre pares académicos internacionales enriquece en múltiples formas nuestros horizontes reflexivos. Aprecio por igual la oportunidad que generan estos intercambios para vivir la experiencia del contacto con la vida cotidiana, en el "estar ahí".

Cuando conocí Cuiabá, Mato Grosso, en 2018, tuve la percepción de ser una extranjera, frente a sus climas y sus paisajes. Más cuando -en los primeros días- vi en la televisión un programa donde enseñaban a preparar recetas con lagarto y un concurso talkshow donde una joven indígena concursaba para cumplir su sueńo de ser dentista y ayudar a su comunidad, -cocinando comida indígena y cantando hermosas canciones en guaraní-, ante los comentarios frívolos de un jurado de famosos del espectáculo.

Como habitante de una región de los muchos Méxicos, en aridoamérica, tengo mucho que aprender de selvas y pantanales y comprendo que lo que para mí es una comida exótica, puede ser un platillo más o menos común en Mato Grosso. Asimismo que las mujeres indígenas mexicanas como las brasileñas, tienen grandes retos para cumplir su sueño de tener educación superior. Nuestras televisoras también tienen mucho por aprender para el abordaje intercultural y la prevención de actos de discriminación cultural y

1 ELIZABETH, Jelin. Los trabajos de la memoria. Madrid, Siblo XXI Editores, 2002, p. 23. 
racismo en los medios. Es inevitable que esos encuentros de realidades, nos generen mil preguntas.

Lo mismo sucede en el intercambio de conocimiento, siempre estamos ejercitando nuestras miradas comparativas y analizando nuestras experiencias históricas y culturales, por ello me permito expresar mis percepciones en torno a la producción de saberes que se encuentra en este libro. Subyace el deseo común no solo de sorprendernos con las diferencias y afinidades para la producción de conocimiento crítico, sino la tarea de construir horizontes intelectuales de memorias vivas de los procesos educativos, de rutas esperanzadoras para el cambio, para mejorar la educación y la vida.

El mapa de actores de la educación que cobran vida en varios de los capítulos de esta obra, emergen de la historia viva matogrossense, desde la oralidad y los documentos históricos. Los investigadores ofrecen hallazgos y configuraciones de las historias de las mujeres, como alumnas adolescentes, como profesoras normalistas y misioneras que fundan escuelas en sitios lejanos; como estudiantes intrusas en espacios masculinos, pioneras que se insertan a los actuales sistemas de trabajo. Entran al final, de mi pluma, las maestras rurales como las constructoras del sistema educativo del México campesino y agreste de principios del siglo XX. Tantos actores y tantas historias en diversos tiempos, y sin embargo, se entretejen en un diálogo que une los temas de la construcción escolar para los sectores populares y los retos de llevar la formación profesional a los más distantes lugares de nuestros países. Tejemos memorias de un conjunto de actos creativos de invención de los mundos educativos.

Las líneas de investigación, las fuentes y las metodologías que podemos encontrar en la obra, destacan en primer lugar los esfuerzos por crear y preservar las fuentes, al producir fuentes orales y fundar acervos documentales universitarios. Primera y valiosa tarea para preservar la memoria viva y colectiva de la experiencia educativa en la región.

Recuperar del olvido a nuevos actores, es también entrar a nuevos debates y lecturas que si bien no desplazan los viejos paradigmas si se atreven a tocar lo emergente en la historia y las ciencias sociales, con temas como la diversidad sexual, las desigualdades (de género, económicas, territoriales, laborales, sociales, etc.). Así, las prácticas emergentes en la enseńanza también están presentes en esta obra. Acaso como búsqueda de sentido, o como experimentación cognitiva, se recuperan los esfuerzos alternativos para enseñar a los estudiantes jóvenes y adultos, tanto como para transformar a los enseñantes, es así, que se exploran y se analizan nuevas formas de enseñanza en temas de matemáticas, de medio ambiente y las habilidades lectoras. 
Preguntas profundas sobre la diversidad sexual en el escenario educativo o sobre los retos de construir la ciudadanía plena para todos y todas, enfrentando los prejuicios, la discriminación y el racismo en las escuelas, forman parte de este tejido de voces emergentes.

Las teorías y nuevos debates están presentes en los escritos de los investigadores, dando agencia a los actores de sus historias, revisando sus conceptos de las ciencias de la educación, tanto como de las teorías de género y del Estado. En congruencia con ello, advierto que las metodologías empleadas en sus investigaciones, favorecen las formas colaborativas, la investigación-acción en la docencia, y la construcción de legados académicos transgeneracionales a partir de la formación de nuevos investigadores, comprometidos también con la preservación colectiva y profesional de las fuentes históricas y de la memoria educativa.

Celebro este intercambio y este libro, que son el testimonio del trabajo de investigación en equipo, del intercambio de memorias vivas y de la construcción activa de conocimiento sobre la educación matogrosense en el siglo XX.

San Luis Potosí, SLP, México, 2 de julio de 2020.

Oresta López Pérez Laboratorio de Investigación:

Género, Interculturalidad y Derechos Humanos Profa. do El Colegio de San Luis, Centro Público de Investigación CONACYT 


\section{SUMÁRIO}

PREFÁCIO vi

Oresta López Pérez

APRESENTAÇÃO.

Nilce Vieira Campos Ferreira

Neil Franco

Oresta López Pérez

PARTE I - HISTÓRIA E MEMÓRIAS DA EDUCAÇÃO. 8

1 LAS MAESTRAS RURALES EN EL MÉXICO POSTREVOLUCIONARIO: IDENTIDAD PROFESIONAL E EMPODERAMIENTO FEMENINO 9 Oresta López Pérez

2 HISTÓRIA DA EDUCAÇÃO NO CENTRO MEMÓRIA VIVA DO INSTITUTO DE EDUCAÇÃO DA UNIVERSIDADE FEDERAL DE MATO GROSSO - UFMT/CAMPUS CUIABÁ 23 Nilce Vieira Campos Ferreira Cleicinéia Oliveira de Souza Nathalia Martins Luna

3 MEMÓRIAS SOBRE O RECRUTAMENTO DE PROFESSORAS RURAIS PIONEIRAS DO SUL DE RONDÔNIA NO SEGUNDO QUARTEL DO SÉCULO XX 38 Marcia Jovani de Oliveira Nunes Josemir Almeida Barros

4 O ASSOALHO DA ESCOLA AINDA “ECOA”: HISTÓRIAS E MEMÓRIAS DE UMA ESCOLA 57

Helen Arantes Martins Alceu Zoia

5 FORMAÇÃO DO MAGISTÉRIO RURAL EM RONDÔNIA NAS DÉCADAS DE 1970 E 1980 : ALGUNS ACHADOS..... 79

Roger dos Santos Lima Josemir Almeida Barros

6 EDUCAÇÃO DAS MULHERES MATO-GROSSENSES: “TRABALHOS DE AGULHAS E DE PRENDAS DOMÉSTICAS NAS ESCOLAS DO SEXO FEMININO...”

Sandra Jung de Mattos

PARTE II - ENSINO, EDUCAÇÃO E SUAS PRÁTICAS 112

7 POLÍTICA DE ASSISTÊNCIA ESTUDANTIL E SEUS REFLEXOS NA PERMANÊNCIA/ NÃO PERMANÊNCIA DE ESTUDANTES NO IFMT CAMPUS VÁRZEA GRANDE ....113 Carminha Aparecida Visquetti Maria Emilia de Castro Rodrigues 
8 IDENTIDADES DOS SUJEITOS LEITORES DA EJA: CLARICE LISPECTOR E A VOZ DOS NEOLEITORES.

Antônia Lúcia de Queiroz Tenório

Rosemar Eurico Coenga

9 FORMAÇÃO DE ESTUDANTES DA EJA:

EDUCAÇÃO E CONSCIÊNCIA AMBIENTAL NA ESCOLA DUQUE DE CAXIAS EM HUMAITÁ/AM

Valmir Flores Pinto

Romilson Brito de Azevedo

10 MODELAGEM MATEMÁTICA NO ENSINO DE FUNÇÃO AFIM EM UMA TURMA DE EDUCAÇÃO DE JOVENS E ADULTOS NO MUNIĆ́PIO DE JUÍNA-MT .......171 Jefferson Bento de Moura

PARTE III - ITINERÁRIOS FORMATIVOS E ESPAÇOS ESCOLARES 184

11 HOMOFOBIA NA RELAÇÃO DISCENTE/DOCENTE: UM ESTUDO NA REGIÃO CENTRO-OESTE BRASILEIRA

Neil Franco

12 MULHERES, LUTAS E REPRESENTAÇÕES:

CAOS, CRONOS E INVENÇÃO DA (DES) IGUALDADE. 208

Qelli Viviane Dias Rocha

13 EM BUSCA DE NOVAS PRÁTICAS DIDÁTICAS NO ENSINO DE HISTÓRIA:

O REGIME DE EXCEÇÃO NA DITADURA CIVIL-MILITAR.

André Luís Monteiro Ferreira Lopes

Maria do Socorro de Souza Araújo

14 FORMAÇÃO LITERÁRIA EM ESPAÇO SOCIOEDUCATIVO:

ENTRE LIVROS LITERATURA E HISTÓRIAS

Rosangela Queiroz Garcia Leite Nogueira

Rosemar Eurico Coenga

15 JOGO "HOSPITAL MIRIM": ANALOGIAS ENTRE SAÚDE E EDUCAÇÃO NO ENFRENTAMENTO À PROCEDIMENTO INVASIVO COM CRIANÇA 251

Kamilla Furtado Regatieri

Tatiane Lebre Dias

16 EDUCAÇÃO E TRABALHO:

MULHERES NO INSTITUTO FEDERAL DE MATO GROSSO (2008 a 2018) ......267

Silvia Maria dos Santos Stering

Nilce Vieira Campos Ferreira

SOBRE AUTORAS E AUTOR (ORGANIZADORAS E ORGANIZADOR) .294 


\section{APRESENTAÇÃO}

O objetivo deste livro é reunir trabalhos de pesquisadoras e pesquisadores das regiôes Centro-Oeste e Norte brasileiras, com o intuito de explorar multiplicidades de investigaçóes que são realizadas no âmbito de diversos grupos de pesquisa e na Rede de Pesquisa, Ensino e Extensão em Educação das Regióes Centro-Oeste e Norte do Brasil e América Latina - RECONALEdu, uma Rede de Ensino, Pesquisa e Extensão que congrega pesquisadoras, pesquisadores e extensionistas com objetivo de ampliar o campo de estudos entre as regióes Centro Oeste e Norte articuladas às ações da América Latina ${ }^{12}$.

Pesquisadoras e pesquisadores dessas regióes têm procurado, em meio à diversidade de suas atividades de ensino, pesquisa e extensão, unirem-se para a socialização de trabalhos realizados nessas regióes. Desse modo, o foco dessa obra volta-se para as pesquisas que debatem temáticas relacionadas à História da Educação e suas práticas, ao ensino, às diversidades regionais e culturais do CentroOeste e Norte brasileiros, acompanhando o movimento de outros trabalhos já produzidos por outras e outros que pesquisam a educação na América Latina.

Acompanhando esse movimento, organizamos a obra em três eixos temáticos distintos, esclarecendo, contudo, que essa organização tem apenas como intuito facilitar a compreensão das temáticas abordadas, a saber: I) História e Memórias da Educação; II) Ensino, Educação e suas Práticas; III) Itinerários Formativos e Espaços Escolares.

Iniciando a obra, em sua primeira parte, História eMemórias da Educação, Oresta López Pérez, expóe no texto Las Maestras Rurales en El México Postrevolucionario: Identidad Profesional e Empoderamiento Femenino, memórias de professoras rurais, mostrando a vulnerabilidade e as fragilidades educativas a que as mulheres que exercem o magistério nas comunidades rurais mexicanas estão sujeitas frente a hostilidade permanente de autoridades educativas que pretendem discipliná-las de acordo com a condição social, sexo, classe e religião. A autora relata que, no México pós-revolucionário, deuse prioridade à educação rural com o objetivo de transformar a situação do campo, o que impulsionou o processo de feminização do magistério com a inserção massiva de jovens mulheres que passaram a atuar na educação rural.

1 http://www1.ufmt.br/ufmt/un/reconaledu

2 Algumas pesquisas contam com o apoio, cujos auxílios financeiros, permitem nossas pesquisas e sua divulgação, como o Conselho Nacional de Desenvolvimento Científico e Tecnológico - CNPq. Na obra há também textos de bolsistas apoiados pela Coordenação de Aperfeiçoamento de Pessoal de Nível Superior - Capes. Outras agências de fomento estão descritas nos textos que compóem à obra. 
A seguir, em História da Educaçáo no Centro Memória Viva do Instituto de Educação da Universidade Federal de Mato Grosso - UFMT/Campus Cuiabá, Cleicinéia Oliveira de Souza, Nathalia Martins Luna e Nilce Vieira Campos Ferreira propóem uma discussão a respeito de a História da Educaçáo no Centro Memória Viva do Instituto de Educação da Universidade Federal de Mato Grosso - CMVIE, UFMT - Campus Cuiabá. As autoras analisam o CMVIE como um espaço de memória institucional e destacam que as fontes documentais existentes em seu acervo são relevantes para a compreensão da história institucional. Nessa compreensão, o CMVIE garante que a memória produzida no âmbito institucional possa ser acessada pela comunidade acadêmica e seu entorno, bem como possibilita que a compreensão de que locais de memória consitutem espaços de pesquisas, ensino e extensão.

Em Memórias sobre o recrutamento de professoras rurais pioneiras do Sul de Rondônia no segundo quartel do século $\mathrm{XX}$, Marcia Jovani de Oliveira Nunes e Josemir Almeida Barros analisam o processo de recrutamento, seleção e contratação de professores pioneiros da educaçáo no município de Colorado do Oeste - RO, no final dos anos de 1970 e início dos anos de 1980 do século XX. Um dos objetivos do texto é apresentar uma interpretação crítica do contexto histórico social do terceiro fluxo migratório para Rondônia que teve origem a partir de a abertura da BR 364. A investigação contou com análise de dados provenientes de narrativas de professoras rondonienses e de fontes documentais. Autora e autor descrevem que a imigração ocorrida no terceiro fluxo migratório para Rondônia foi propositalmente direcionada e colocada na regiáo Sul do Estado pelos militares por meio da ação de projetos de assentamento e colonização do Instituto Nacional de Colonização e Reforma Agrária - INCRA, uma vez que os militares detinham conhecimentos e documentos que apontavam o potencial de fertilidade das terras rondonienses. Professoras e professores leigos foram contratados segundo poucos ou nenhum critério de seleção, não apenas para remediarem a situação da educação no estado, mas principalmente, porque eram necessários diante do projeto político social de organizaçáo do estado, com o intuito de manter os migrantes na regiáo.

Helen Arantes Martins e Alceu Zoia investigam a formação educacional escolar de Vilhena/RO, entre o período de 1960-1980, notadamente no que se refere à implementação da Escola Wilson Camargo, primeiro estabelecimento de ensino da regiáo, no texto intitulado $O$ assoalho da escola ainda "ecoa": histórias e memórias de uma escola. 
Pelos caminhos de a história oral, memória e abordagem qualitativa a partir de estudos históricos, analíticos e documentais de acervos escolares e acervos particulares, autora e autor descrevem entrevistas realizadas com ex-professores e ex-alunos que viveram a dinâmica do período delineado e que, hoje, narram as experiências individuais e coletivas daqueles que regeram os fatos. O estudo corrobora a concepção de que a escola parece ser a principal referência de formaçáo para a sociedade.

Acompanhando essa temática Formaçáo do Magistério Rural em Rondônia nas Décadas de 1970 e 1980: alguns achados, Roger dos Santos Lima e Josemir Almeida Barros debatem as principais políticas de formação do magistério rural ocorridas nas décadas de 1970 e 1980 em Rondônia. Os autores analisam documentos históricos, tais como leis, decretos, pareceres, instrução normativa, resolução e matéria de jornal, além de dados estatísticos escolares. Para os autores, a análise dos documentos deixou de representar fontes que por si só reproduzem verdades ou que definem o passado como um acontecimento rígido, que não poder ser alterado e ressalvam que a verdadeira história não está expressa apenas nos modelos de urbanização das localidades, mas também no meio rural e nas regióes mais distantes. Dessa forma, voltam seu olhar para não só a educação no meio rural, mas também para meio o urbano, tentando compreender as duas facetas ali engendradas, contudo, concluem que que as escolas rurais historicamente vêm sendo expropriadas de seus saberes, tradiçóes e culturas.

Em Mato Grosso, nos primeiros anos republicanos, poucas eram as escolas existentes para a escolarização das mulheres. Com essa temática, Sandra Jung de Mattos explora a Educação das Mulheres Mato-Grossenses: "trabalhos de agulhas e de prendas domésticas, nas escolas do sexo feminino...”. No período histórico demarcado pela pesquisa, a autora utiliza fontes tais como: regulamentos emitidos pelos Presidentes no período e relatórios emitidos pela Diretoria de Instruçáo de Mato Grosso para analisar o ensino que era ofertado às mulheres, às quais eram atribuídas determinadas atitudes e açóes que perpassavam os espaços educativos de formação feminina.

$\mathrm{Na}$ segunda parte da obra, iniciando o eixo temático Ensino, Educaçáo e suas Práticas, no texto Política de Assistência Estudantil e Seus Reflexos na Permanência/Náo Permanência de Estudantes no IFMT, Campus Várzea Grande, Carminha Aparecida Visquetti e Maria Emília de Castro Rodrigues evidenciam como a política de assistência estudantil contribui ou não para viabilizar o acesso, a permanência e êxito de estudantes na Educação de Jovens e Adultos - EJA. As autoras optaram pelo estudo de caso e analisaram documentos, bem como resultados de entrevistas semiestruturadas e grupo focal. 
Visquetti e Rodrigues destacam que as trajetórias de vida dos sujeitos trabalhadores são assinaladas, em sua maioria, por percursos de vidas, cujos históricos são marcados pelas rupturas em seus trajetos educacionais, o que confere importância à Política de Assistência Estudantil como elemento favorecedor do acesso, permanência e conclusão de estudos por estudantes da EJA.

Antônia Lúcia de Queiroz Tenório e Rosemar Eurico Coenga buscam discutir o desenvolvimento da capacidade leitora de neoleitores a partir de pressupostos concernente à leitura literária proposta por Rildo Cosson (2016) no texto Identidades dos sujeitos leitores da EJA: Clarice Lispector e a voz dos neoleitores. A investigação teve como universo uma turma do ensino médio do Centro de Educação de Jovens e Adultos Professor Antônio Cesário de Figueiredo Neto, no município de Cuiabá. Para isso, adotaram um arcabouço metodológico descritivo cujos resultados apontam a necessidade de articulação entre mediadores de leitura no âmbito acadêmico, aliados ao uso de metodologias e estratégias de leitura sistematizadas e eficazes para formação de neoleitores.

Com o objetivo geral de refletir sobre a conformaçáo de valores fundamentais na construçáo da consciência ambiental na percepçáo dos estudantes da Educaçáo de Jovens e Adultos- EJA, Valmir Flores Pinto e Romilson Brito de Azevedo no texto Formaçáo de estudantes da EJA: Educação e consciência ambiental na Escola Duque de Caxias em Humaitá/AM, propóem uma análise sobre o cotidiano em sala de aula, de modo a discutir às questóes relacionadas ao meio ambiente e à áreas de conhecimento, considerando o respeito e o relacionamento dos seres humanos com a natureza.

Apresentando a pesquisa Modelagem Matemática no Ensino de Funçáo Afim em uma turma de Educação e Jovens e Adultos no município de Juína-MT, Jefferson Bento de Moura discute as possibilidades de atividades diferenciadas na Educação de Jovens e Adultos - EJA por meio de a Modelagem Matemática, verificando sua contribuição no processo de aprendizagem dos alunos da EJA, com bases em testes que foram aplicados antes e depois de a utilização dessa ferramenta de complementação didática. A análise apresentada permite visualizar que uma abordagem diferenciada, como forma explicativa e expositiva de conteúdo, permite comprovar, de forma clara e concisa, a importância de se buscar uma formação de conceitos matemáticos a partir de uma proposta didática e pedagógica mais coerente com a Educação de Jovens e Adultos no processo de ensino-aprendizagem. 
Itinerários Formativos e Espaços Escolares, o terceiro e último eixo da obra, principia com a discussão levantada por Neil Franco no texto Homofobia na relaçáo discente/docente: um estudo na Regiáo CentroOeste Brasileira, teoricamente, fundamentado nos conceitos de identidade e diferença e nas reflexóes elaboradas pela teoria queer, aborda aspectos históricos com relação à (re)construção das identidades sexuais e de gênero. Dentre valores que nos apresenta, o autor destaca que a forma como homens e mulheres devem viver suas sexualidades e construir seu gênero constituemse aprendizados naturalizados e muitas vezes imperceptíveis. Além disso, Franco constata que essas vivências são aceitáveis socialmente desde que não tenham suas fronteiras ultrapassadas ou em trânsito, levando-o a analisar a escola como um lugar representativo como instituição social, mas que tem como objetivo o ensino, a aprendizagem e a manutenção de diversos valores que constituem a sociedade na qual ela está inserida.

Contextualizando Mulheres, lutas e representaçóes: Caos, Cronos e a Invenção da (Des) Igualdade, Qelli Viviane Dias Rocha inicia sua reflexão, partindo de a apropriação grega de Hesíodo, segundo a qual podemos por meio de sua 'poiesis', apreender a construção alegórica da Criação. Desta forma, a autora evidencia como a construção social e histórica da cidadania inscrevem uma dualidade que pontua e ratifica binarismos, tanto sobre as relaçóes sociais de sexo entre os homens e mulheres, quanto da própria categoria cidadania que, como uma sofisma estabelece mediaçóes e formas de manutenção de relações (des) iguais. Para ela, as formas de superação desse modo de produção tem em si seus próprios limites, contradiçóes e antagonismos, destacando como a luta das mulheres no processo de constituição de sua representação pode representar um perigo ao se distanciar dos processos de construção de identidades-unitárias.

André Luís Monteiro Ferreira Lopes e Maria do Socorro de Souza no texto Em busca de novas práticas didáticas no ensino de História: o regime de exceçáo na ditadura civil-militar na qual abordam o tema regime militar e evidenciam o que ficou conhecido como Milagre Econômico no Brasil. Lopes e Souza analisam a produção bibliográfica encontrada no livro didático titulado 1964-2004: 40 anos do golpe, organizado por Fico e Araújo (2004), no qual encontraram vários artigos sobre a temática e apresentam algumas reflexóes sobre as questóes econômicas que desembocaram na ditadura civil militar brasileira vivenciada a partir dos anos de 1960 .

$\mathrm{Na}$ obra Formação Literária em Espaço Socioeducativo: entre Livros Literatura e Histórias, Rosangela Queiroz Garcia Leite Nogueira e 
Rosemar Eurico Coenga discutem e analisam medidas socioeducativas adotadas no Centro de Atendimento de Internação Provisório e Internaçáo Feminino de Cuiabá em um programa de escolarizaçáo oferecido pela Secretaria de Estado de Educaçáo de Mato Grosso. Nogueira e Coenga mapearam modos de incentivo à leitura, por meio de relatos de participantes entrevistadas, identificando critérios que balizam as escolhas de leituras pelas jovens/adolescentes.

Em outra dimensão de investigaçáo, as autoras Kamilla Furtado Regatieri e Tatiane Lebre Dias têm como objeto de estudo o uso de o Jogo Serious Game Hospital Mirim. O texto Jogo "Hospital Mirim": relaçóes entre saúde e educaçáo no enfrentamento à procedimento invasivo com crianças apresenta uma análise entre educação e saúde no processo de enfrentamento para o procedimentos invasivos. $\mathrm{O}$ jogo é avaliado a partir de sua funçáo educativa, uma vez que ensina as etapas do procedimento de coleta de sangue por meio de diálogos. Como procedimentos metodológicos, as autoras utilizaram entrevista semiestruturada, escala de dor e o jogo Hospital Mirim. As análises apontaram que os processos lúdicos promovidos a partir de o uso do Jogo Serious Game Hospital Mirim ajudaram no processo de aprendizado, uma vez que permitiu conhecer as etapas realizadas no procedimento.

Por fim, no texto Educaçáo e Trabalho: Mulheres no Instituto Federal de Mato Grosso (2008 a 2018), Silvia Maria dos Santos Stering e Nilce Vieira Campos Ferreira estudam a participação de mulheres no universo de uma instituição escolar de relevância para a formação de trabalhadoras e trabalhadores em Mato Grosso. As autoras partem da hipótese de que, na instituição estudada, prevalece um conflito latente produzido por certo grau de coerçáo historicamente exercido sobre as mulheres. A partir de fontes como legislação, imprensa local e oficial, trazem parte da memória da instituição destacando que a participação e atuação das mulheres na instituição faz parte de um longo processo de busca por garantia de direitos junto a uma instituiçáo cujo processo de organização só muito recentemente ampliou os quadros de atuação permitidos às mulheres.

Temos assim, nos textos que são apresentados, pesquisas e estudos que nos permitem conhecer, de forma densa, os estudos que são desenvolvidos nas regióes nas quais estáo inseridos. Autoras e autores cuidadosamente nos afastam do esquecimento táo comuns nos dias de hoje e nos aproximam de memórias, histórias, práticas e saberes. 
Pesquisadores e pesquisadoras lançam para além de si, de suas redes e grupos, vínculos que se articulam e estendem em uma educação coletiva que reelabora e rememora a educaçáo que se faz nas regióes Centro-Oeste e Norte brasileiras.

Desejamos uma leitura prazerosa!

Nilce Vieira Campos Ferreira Neil Franco Oresta López Pérez 


\section{PARTE I \\ HISTÓRIA E MEMÓRIAS DA EDUCAÇÃO}




\section{LAS MAESTRAS RURALES EN EL MÉXICO POSTREVOLUCIONARIO: IDENTIDAD PROFESIONAL Y EMPODERAMIENTO FEMENINO}

En el México postrevolucionario, se dio prioridad a la educación rural con el objetivo de transformar la situación del campo y para sacar del atraso a la mayoría de la población que eran campesinos. A la par se impulsó un proceso de feminización del magisterio, logrando como nunca antes, la inserción masiva de jovencitas a la educación en las regiones.

Tras una quimera utópica, diría Monsiváis (2014), en el marco de una política cultural patriarcal según Vaughan (2013), cientos y hasta miles de mujeres se convirtieron en maestras del campo. En su formación, tuvieron que aprender a hacer las tareas del mundo campesino bajo las prescripciones de la SEP o bien, -siendo urbanas-, adquirir capacidades para el trabajo en el campo, para poder ser agentes de cambio en su labor educativa.

En el presente capítulo, con documentos del AHSEP y entrevistas, se recuperan datos, experiencias y voces de maestras que en formas inéditas, aprendieron con los campesinos y misioneros culturales, a participar de la vida y producción campesina. Mediante intersaberes campesinos, cultivaron parcelas y huertos escolares, hicieron gallineros, cooperativas agrícolas y muchas otras actividades que no siempre correspondían a su realidad cotidiana o a su región. Los testimonios muestran el autodescubrimiento y empoderamiento de las maestras frente a nuevos oficios, peligros y roles inesperados que tuvieron que asumir. Siendo natural por entonces que las maestras ganaran menos, que no tuvieran novios, que no se casaran ni tuvieran hijos, el reto mayor era conquistar la igualdad de salarios, los derechos maternales y mantenerse vivas, en un contexto donde la violencia e inseguridad, el machismo, los controles de los poderes locales y caciquiles y hasta las frecuentes epidemias en los pueblos, hacían que las maestras fueran empleadas del estado en condiciones de vulnerabilidad y por ello sometidas a una rotación permanente en sus empleos.

Muchas de las mujeres que entraron al oficio de maestra, no se quedaron, solo tuvieron experiencias efímeras en la educación, pero salir del nicho 
familiar les ofreció nuevas experiencias y cierta fortaleza construida en las adversidades que enfrentaron en los pueblos y por jugar un papel histórico, como pioneras de la educación.

La historiografía y las teorías de género aportan a la posibilidad de una interpretación más rigurosa de la presencia de las mujeres en la construcción del sistema educativo rural. Una de las hipótesis que sostengo en este trabajo consta de dos componentes.

El primero, la feminización del magisterio rural en México, constituyó un fenómeno masivo en el periodo de Gobierno de Álvaro Obregón, con José Vasconcelos, al frente de la Secretaría de Educación, como una forma de política de estado para incorporar a las mujeres a la educación pública de masas. Haciendo eco de la política modernizadora de la educación y de los llamados internacionales a la transformación de la condición de las mujeres para modificar el modelo femenino porfiriano.

En el segundo, a la par que se lanza la campaña de recorrer el país, llegar a los pueblos indígenas y promover el modelo de escuela rural mexicana. Las mujeres aprendieron entonces saberes inesperados. Es decir que aún siendo mujeres de poblaciones rurales medias no realizaban tareas rurales o bien siendo de mujeres de ciudad, menos aún. Las mujeres campesinas e indígenas participaron poco, en calidad de profesoras, en esta gran cruzada educativa. Por tanto las mujeres entraron a la profesión feminizada bajo condicionantes de profesionalizarse como maestras rurales, de moverse al campo y de aprender nuevos saberes para realizar su trabajo educativo.

Las misiones culturales y las escuelas normales rurales se ocuparon de enseñar estos nuevos saberes a los maestros y maestras del campo.

\section{El predominio de un modelo educativo}

Los dos grandes proyectos educativos de la posrevolución, heredados por José Vasconcelos fueron las Casas del pueblo y las Misiones culturales, el primero dio paso a un modelo educativo basado en escuelas rurales y el segundo dio lugar a las normales rurales. Para atender el proyecto consentido, se formó el Departamento de Escuelas Rurales, Primarias foráneas e incorporación cultural indígena. ${ }^{1}$

1 Es fascinante entrar a las cajas de los archivos de esta dependencia, pues autoridades, maestros y campesinos dejaron voces en la correspondencia que enuncian un momento fundante y creativo de la educación del campo. Asimismo la cantidad de plazas que se generaron en estas décadas no tiene precedentes en la historia de la educación en México. 
Los autores coinciden en afirmar que ese sistema nació con más intuición que con fundamento pedagógico, que surgió de las demandas del pueblo. Fue entre el grupo de Directores de Educación Federal que se dio el debate sobre los fundamentos del mismo y solo hasta 1926 gracias al trabajo de José María Bonilla - Subjefe de Escuelas Rurales-, se contó con las bases del modelo. Mismas que mostraré a continuación:

Se propone llevar nuevos conocimientos a los campesinos para alfabetizarlos, racionalizar la agricultura y generar pequeñas industrias. Pues el futuro económico de México lo veían en el cultivo inteligente de la tierra y en las industrias agrícolas.

Con el objetivo de la mejora de los cultivos: se propone un enfoque de colaboración de los maestros para aprender de los campesinos, con un enfoque que ahora llamaríamos constructivista, pues procuraban recuperar la experiencia, los conocimientos que ya tenían los campesinos, para que dialogaran con los técnicos agrícolas. La idea era enseñar más afuera del aula, en la vida comunitaria, haciendo un programa práctico, acorde a esta relación con las actividades del campo, haciendo adaptaciones a las necesidades de cada lugar, con programas particulares.

La escuela rural como instrumento de búsqueda de equidad y justicia: 'Es la institución educativa más democrática; primero porque se dirige a al mayor número, y después, porque está llamada a corregir el error en que hemos incurrido durante más de un siglo, de formar, mediante la educación, unos cuantos sabios en medio de millones de analfabetas'. (VILLALPANDO, 2012, p. 387).

Señala que por ética, deben combatir formas de degeneración de la raza que prevalecen en los campesinos ${ }^{2}$ : como el fanatismo, alcoholismo y las uniones sexuales prematuras. Se pretende levantar el nivel social de los conglomerados indígenas y de los desheredados que forman las peonadas, que son todo un problema social y económico.

Propone el uso del idioma castellano para incorporar a los indígenas y promover la solidaridad entre indios y mestizos, como piedra angular para construir la nación.

2 Se referían constantemente a la raza indígena, como si tuviera rasgos genéticos desventajosos desde una perspectiva biologicista, en algunos textos señalaban que esas desventajas eran producidas por la dominación y explotación desmedida, histórica y tradicional ejercida por los hacendados y caciques sobre los indígenas. 
La escuela rural no debe ser estigmatizada como rudimental, sino se promoverían desde este modelo todos los grados, hasta los más elevados.

El modelo reivindica una nueva cultura de género: 'La escuela rural es mixta, con el fin de lograr, simultáneamente la cultura de hombres y mujeres, y hacer que desaparezcan las desigualdades que han perdurado a través de los tiempos, convirtiendo a la mujer en una esclava del hombre'. (VILLALPANDO, 2012, p. 387).

La reglamentación del modelo de educación rural vigente, obligaba a trazar nuevas relaciones con las clases oprimidas, con la comunidad y con las mujeres.

Las escuelas rurales, como nunca antes, promovieron la participación democrática de la comunidad, a partir de los comités de educación, incorporando a los padres y madres de familia y atendiendo las reglas que indicaban claramente que la tesorera fuera una mujer.

Las maestras tenían que trabajar con estos comités para construir los anexos de las escuelas, tales como: huertos, campos deportivos, gallineros, teatros al aire libre. Realizaban tareas muy diversas como fomentar la vida laica, realizar las ceremonias cívicas, festivales culturales, concursos y deportes escolares y comunitarios. Gestionar apoyos para llevar adelante el programa y para conseguir dotaciones para material escolar y cubrir necesidades básicas de los niños y niñas, desde zapatos hasta uniformes o ropa.

Las maestras además organizaban a las mujeres para que participaran en la mejora de la dieta de los niños, para dar un almuerzo caliente, todos los días a los niños.

El contexto de estos años marchaba en torno a una política pública que movía proyectos del centro a los estados. Asimismo, la creación de instituciones que incorporaban a jóvenes indígenas a diversos proyectos en pueblos y ciudades. ${ }^{3}$ Hubo también muchos experimentos, algunos muy exitosos como las misiones culturales, otros no tanto, como el fracaso de las escuelas centrales agrícolas a las que llegaron jóvenes urbanos que no siempre lograron conectarse con la visión campesina.

No obstante en el terreno de la educación normal y de formación de maestros, se lograron resultados diferentes. Pues se incorporaban hombres

3 Como fue el caso de la Casa del Estudiante Indígena, que reunió estudiantes de varios pueblos indígenas. Al final de sus estudios ninguno regresó a sus pueblos. 
y mujeres, donde los menos eran campesinos, pero que les ofrecían la posibilidad de profesionalizarse en la educación y tener una forma modesta de vivir. El plan de estudios para la educación rural, significaba una intensa concientización de los retos del país, lo cual elevaba su sentido de politización y de vocación en el servicio.

\section{Una coyuntura para que las mujeres se convirtieran en maestras rurales:}

Entre la bibliografía que ha problematizado y analizado la presencia de las mujeres en el proyecto de educación rural posrevolucionaria, destaca el trabajo de Mary Kay Vaughan, quien afirma que:

La Revolución no fue sólo un ataque contra la propiedad, la jerarquía social y la exclusión: fue una embestida contra la moral victoriana y las reglas de represión sexual, llevó a las mujeres al espacio público en formas nunca antes vistas. (CANO, OLCOTT Y VAUGHAN, 2009, p. 45).

Las mujeres en busca de cambios sociales se enfrentaban a las estructuras patriarcales que pensaban la pacificación restableciendo el orden de género, imponiendo los roles más tradicionales. La posrevolución y sus reformas, de algún modo daban refugio a las mujeres en el Estado, como maestras, trabajadoras sociales, enfermeras, secretarias y otro tipo de oficios. Tanto en la ciudad como en el campo. Muchas elegían la aventura de irse de maestras o enfermeras rurales, que eran las plazas disponibles. Pero incluso para las mujeres del campo educadas en patrones conservadores, el trabajo de maestra rural implicaba retos fuertes para aplicar las nuevas propuestas pedagógicas que demandaban involucrarse en el trabajo agrícola y aprender a cultivar y cuidar los huertos escolares o promover el modelo de educación rural.

Al analizar, desde los expedientes personales, los saberes de las maestras, encuentro que tenían grandes retos formativos para integrarse en las mejores condiciones a la reforma educativa rural y socialista. Lo cual demandaba de ellas romper con atavismos y estereotipos, ser críticas con las prácticas católicas vigentes para las mujeres y aprender rápidamente una serie de saberes que les permitieran asumir las nuevas identidades laborales que demandaba el estado. 


\section{Nuevos saberes, nuevas identidades, de las maestras rurales:}

En diferentes estudios que he realizado y publicado, sobre los saberes de las maestras rurales, he descrito listados de tareas que realizaban a partir de sus informes ${ }^{4}$. Algunos de estos hallazgos proceden de informes de las escuelas del estado de Hidalgo. A partir de 2008-2010 realicé una base de datos nacional con referencia al fondo de Maestras Rurales del Archivo Histórico de la SEP, que tiene un reporte de 3,395 expedientes de maestras de todo el territorio mexicano, durante el periodo de 1924 a 1960 aproximadamente.

Encontré que sólo 53 declararon saber agricultura, incluso la mayoría de ellas, muy probablemente lo aprendió en los cursos de perfeccionamiento con las misiones culturales, pues coincide también con esta información. Todo ello muestra que eran saberes en su mayoría aprendidos bajo el nuevo modelo educativo.

Figura 1 - Saberes.

\begin{tabular}{|c|c|}
\hline \multicolumn{2}{|c|}{ Saberes declarados en primer lugar por las maestras al momento de } \\
su contratación, 1924 - 1934 \\
\hline 279 & Bordados y tejidos \\
\hline 53 & Agricultura \\
\hline 20 & Calado de madera \\
\hline 10 & carpintería \\
\hline 6 & apicultura \\
\hline 3 & alfarería \\
\hline 2 & avicultura \\
\hline 2 & zapatería \\
\hline 2 & curtiduría \\
\hline 1 & albañilería \\
\hline Elaboración propia: con datos del Fondo de Maestras rurales del AHSEP. \\
\hline
\end{tabular}

Fonte: A autora.

4 Conforme López ( 2001). 
Es decir, la mayoría de las mujeres contratadas no tenía los saberes rurales que requería el nuevo modelo educativo. Prevalecía el esquema de saberes tradicionales de las escuelas de nińas desde el siglo XIX como las labores de aguja. El salto a las tareas socialistas requería de maestros y maestras estudio y saberes agrícolas y organizativos para asesorar a los campesinos. Pero esta situación no era exclusiva de las maestras. Es importante aclarar que las mismas misiones culturales seguían promoviendo los saberes femeniles decimonónicos, pero ahora con un contenido político diferente y revolucionario, se trataba de llevar esos refinamientos a las mujeres rurales y del campo. Así las misiones culturales también hacían adaptaciones en las comunidades, pues el bordado podía aplicarse a la elaboración de artesanías con fibra del ixtle de las comunidades para la elaboración de bolsas y de cunas, entre otras cosas.

En sus testimonios hablan de estas tareas como una novedad en sus saberes, declaraban que se volvieron campesinas, que tenían que aprender cómo cuidar un huerto o dirigir la elaboración y cuidado de la hortaliza de la escuela, o cuidar animales, ya que eran parte de los contenidos curriculares, inseparables del programa escolar y que serían supervisados por las autoridades.

Las misiones culturales promovieron una serie de conocimientos nuevos y transformaciones en la vida de las mujeres que entraban al oficio de enseñar. Empezando por una nueva estética de su presentación personal. Esto lo hacían en los internados o bien en sus estancias en los institutos de capacitación. Acorde con las modas de la capital, Las llamadas "pelonas" y vestidas a la flapper, mujeres atléticas y dinámicas, se convirtieron también en el modelo que adoptó la Secretaria de educación para las maestras rurales de todo el país. Todas hacían filas para que el peluquero de la Misión Cultural les cortara el pelo y lucieran cortes modernos; aprendían a usar las faldas-pantalón para hacer deportes y para aprender a bailar; a usar el traje de baño y nadar en grupo con agua fría en balnearios y en el río; a montar a caballo y a ser autónomas en su autocuidado.

Algunas maestras señalaron que tuvieron que aprender a manejar un arma, que incluso se convertía en herramienta de defensa y seguridad en los pueblos y de necesidad, en los momentos de conflicto en las regiones cristeras.

Las maestras usaron el pelo corto a pesar de que en esos momentos las "pelonas" fueron señaladas a lo largo de la primera mitad del siglo XX, como personas atrevidas, o de baja moralidad. Existe un estudio de la 
violencia de género ejercida en la Ciudad de México contra un grupo de alumnas, que fueron rapadas con violencia, por un grupo de estudiantes de la vocacional. También las identidades de las maestras fueron asociadas a "las pelonas" pues:

Las mujeres comunes y corrientes también se topaban con el nuevo estilo atlético promovido por el Estado, sobre todo mediante su adscripción a varios programas y proyectos de la Secretaría de Educación. La gente asociaba las actividades patrocinadas por el estado, como el entrenamiento de cientos de jóvenes que habrían de ser maestras de gimnasia de la nueva escuela de la ciudad de México planeada ex profeso, con la tendencia más general hacia el movimiento "moderno" del cuerpo femenino en el arte y el deporte -ahora practicado frente a un público-, y con las nuevas modas que adoptaban algunas jóvenes urbanas. De tal suerte, las críticas a la mujer joven y a la moda en 1924 equivaldrían, por extensión, a criticar el proyecto político al que ellas se habían incorporado. (RUBENSTEIN en CANO, OLCOTT y VAUGHAN, 2009, p. 99).

Las maestras rurales, así también transformaban su identidad tradicional, dejando los faldones y el corset, promoviendo nuevos cuerpos, que representaban entonces la inmoralidad para muchas poblaciones.

Más allá de sus reportes de saberes en su hoja profesional, por las entrevistas, sabemos de otros saberes que tendrían que dominar. Por ejemplo, para poder iniciar las clases, ellas tenían que elaborar lo gises, a veces el pizarrón, pero también la tinta y hasta los muebles escolares. Hacían gises de yeso, preparaban la tela apizarrada con pintura y manta y hacían tinta del árbol de huizache.

Aseaban la escuela, la pintaban, la reparaban con ayuda de los padres de familia. Incluso también hacían tareas de carpintería y albañilería, sabían hacer ladrillos, construir hornos para el pan. Algunas además declararon que sabían confeccionar ropa, que tocaban el piano, que pintaban a mano, que sabían hacer flores, algo de farmacia como mentolatum, crema para la cara y otros remedios. Todo era útil para estas comunidades, decían.

Lo cierto es que prevalecían los conocimientos domésticos y muy pocas podían declarar poseer conocimientos avanzados sobre cultivos o industrias agrícolas, menos aún las que se metieron a organizar a los hombres del campo para lograr "cultivos más racionales". Incluso en estudios recientes, hemos identificado que en las normales rurales, se daban conocimientos agrarios 
diferentes y más limitados para las mujeres. ${ }^{5}$ El currículum construido para la capacitación de maestros, el de las normales rurales y los expedientes laborales ofrecen una diversidad de información para conocer a las mujeres de la primera mitad del siglo XX, que de conjunto muestran la continuidad de la formación doméstica tradicional de las mujeres.

\section{Las maestras rurales, su profesionalización en los pueblos}

La Revolución Mexicana, movió de sus lugares de origen a muchas familias. Así sucedió también durante la rebelión cristera. Para los maestros era obligado moverse e irse a trabajar a las zonas que les fueran asignadas. El gobierno los capacitaba regularmente para poder llevar enseñanzas a los pueblos.

Así la maestra Guadalupe Mejía, que estudió en la Normal Socialista de Pachuca Hidalgo, afirma que aún siendo urbana su escuela

[...] nos enseñaban cosas muy útiles, teníamos al maestro Manuel Sosamontes que era de Jalisco y nos enseñó a trabajar las parcelas escolares, practicábamos la agricultura en terrenos de Venta Prieta. Salíamos de la Normal a las 6 de la mañana, vestidos con overoles, íbamos corriendo y cantando el himno del agrarista, preparábamos almácigos de chile, jitomate y frutos, pero nunca llegamos a cosechar porque regalábamos las plantitas listas para el trasplante a los campesinos. La intención era capacitarnos para que nosotros pudiéramos orientar a los campesinos, pero yo creo que los estudiantes nunca sabríamos más que los campesinos porque ellos desde que nacen viven en contacto con la naturaleza y con solo ver las estrellas ya saben que va a pasar ${ }^{6}$.

"Los maestros rurales teníamos que aprender muchas cosas", me decían las entrevistadas. La falta de medios de transporte, hacía que se quedaran en las comunidades y además participaban de muchas responsabilidades: "el maestro [...] era el doctor, el sacerdote, la enfermera, el guía moral, hacía de todo y todo lo hacía."7

5 A respeito ver LÓPEZ y HERNÁNDEZ, (2019).

6 Entrevista a la Mtra. Guadalupe Mejía, realizada por Oresta López en Pachuca Hgo. en 1993.

7 Ibid. 
Las maestras también aprendieron de otras maestras siendo aprendices y ayudantes. Como la Maestra Siria Trejo que aprendió a trabajar en escuelas de circuito para hacer méritos. ${ }^{8}$ Las maestras hidalguenses como la maestra Siria Trejo, que aspiraban a tener un título, se metieron a estudiar a la Escuela Rural de El Mexe, cuando había internado mixto y recuerda que entonces era socialista. Ahí conoció a su esposo con quien se casó y los mandaron a trabajar a una escuela rural de una comunidad Nañú.

[...] en el Mexe nos enseñaron que teníamos que dar servicio a la comunidad. Los maestros en clases nos hablaban del socialismo y nos decían que teníamos que desfanatizar y no permitir que los curas se entrometieran en la educación. Que el socialismo era orientar al campesino, de cómo trabajar, de cómo vivir, de cómo explotar la tierra, buscando que todo fuera igual, que nadie fuera más que el otro; y que se hicieran las cooperativas de ejidatarios o particulares para lograr que nadie se quedara sin comer. ${ }^{9}$

En varias regiones del país los maestros rurales que colaboraron en la reforma agraria, también recibieron dotación de ejidos para arraigarse en las regiones. Con ello, se confirmaba una política educativa que favorecía de algún modo un proceso de campesinización del magisterio rural mexicano. Desconozco los datos de la cantidad de maestras que fueron beneficiarias del reparto agrario, pero no creo que fueran muchas ya que la legislación agraria solo beneficiaba directamente a las madres solteras y a las viudas.

Estas maestras socialistas, se convirtieron en mujeres fuertes, presentes en las decisiones de las comunidades y con capacidad de interlocución con el Estado.

No obstante, a decir de sus testimonios, era difícil de cambiar la manera de pensar de la gente y de los hombres. Vivían en conflicto con sus parejas que no coincidían siempre con lo que ellas hacían. También era reciente que las maestras pudieran tener esposo en forma pública, sin duda, el orden social y de género les impedía ocupar un lugar mejor, pese a su liderazgo en los pueblos.

Es decir al ser socialistas, cortarse el pelo, vestirse de otro modo y estar con el gobierno, eran vistas como transgresoras del orden social.

8 Las escuelas de circuito reunían a niños y niñas de varias comunidades pequeñas bajo la enseñanza de un solo profesor, no titulado. Los maestros aspirantes a una plaza, empezaban a aprender en este tipo de escuelas, generalmente ubicadas en pueblos distantes de las cabeceras municipales.

9 Entrevista a la Mtra. Siria Trejo Lara, realizada por Oresta López el 26 de abril de 1989. 
Eran el centro de las miradas en las comunidades, en pequeños mundos en donde los poderes patriarcales tradicionales no veían con buenos ojos los proyectos posrevolucionarios. Al respecto dice Temma Kaplan, que en el proceso de restablecer alguna forma de orden social, "los gobiernos posrevolucionarios con frecuencia inventan nuevas restricciones, intentando contener la sensación de caos que casi inevitablemente sucede a la destrucción del anterior régimen de autoridad". (CANO, OLCOTT Y VAUGHAN, 2009, p. 407).

El panorama de la abundante documentación de las vidas profesionales de las maestras, muestra las entrañas de la feminización del magisterio en este país. Prevaleciendo las huellas de la vulnerabilidad de las carreras de las mujeres-maestras, las fragilidades educativas con las que ingresaban al servicio en las comunidades rurales, así como el inconstante comportamiento laboral a lo largo de los años frente a una hostilidad permanente de las autoridades educativas que pretenden disciplinarlas y sustraerlas de su condición social, de sexo, clase y religión.

$\mathrm{Al}$ parecer fueron pocas las que pueden dedicarse plenamente a la profesión y tener carreras exitosas, con ascensos y mejoras salariales. Predomina la imagen de las que son mujeres pobres y que renuncian y piden permisos constantemente a lo largo de sus vidas. El fenómeno de rotación constante de las profesoras, cambiando de pueblos, se debía en mucho a las condiciones de pacificación precaria en varias partes del país.

La historia de la violencia de género y la precariedad también aparece registrada en los expedientes, las maestras son afectadas por la violencia sexual en las comunidades en dos sentidos: a) la violencia hacia las mujeres en general, que ejercían los hombres desde ámbitos de superioridad como supervisores, militares, hacendados y políticos. Identificamos varios tipos de violencia, especialmente la de tipo económico, físico, sexual y psicológica. Que podía ser por pagarle menos que a los varones, o incluso no pagarles sus decenas.

Hasta las maestras que eran asaltadas por bandidos de los caminos; los documentos registran maestras violadas por hacendados y militares. También se registraron casos de acoso ejercido por supervisores educativos y políticos locales. b) la violencia hacia las maestras como representantes del estado, es característica de lo que se considera violencia en contexto de guerra, dirigida hacia profesores y profesoras por representar el proyecto anticlerical del estado.

También la violencia política, derivada de la reacción de terratenientes frente a la reforma agraria, que promovían los profesores. David Raby, demuestra, con mucha documentación, este tipo de violencia que viven 
los docentes en este periodo. Afirma que se debe al papel político y de intelectuales orgánicos que jugaron los maestros en el periodo reconstructivo de la Revolución Mexicana. ${ }^{10}$

La documentación incluida en los expedientes personales de las maestras, hace visibles los datos acerca de la salud de las mujeres. Las maestras mueren de enfermedades contagiosas como paludismo, sarampión, viruelas, y de otras no dichas o encubiertas como (debilidad y agotamiento). En un periodo en que apenas se podía contar con atención médica en la ciudad de México para los profesores de la Secretaría de Educación, podemos afirmar que el apoyo del estado era más bien limitado.

\section{A manera de conclusión}

Los jóvenes que se hicieron maestros y maestras en la posrevolución, participaron de uno de los proyectos más ambiciosos de Historia del siglo XX en México, como lo fue el proyecto de educación rural. Las mujeres participaron en formas muy activas en este movimiento, a pesar de los contextos de violencia en las regiones se sumaron a la educación rural de inmediato; procuraron su capacitación en la adquisición de nuevos saberes para la atención a las escuelas del campo y adoptaron nuevas identidades, tuvieron saberes inesperados en su condición de género y se aproximaron a conocer e intervenir en la realidad social. Todo este proceso se inserta además en la complejidad de los procesos de feminización del magisterio mexicano.

Los estudiosos de estos procesos, enfrentamos el reto de construir cuidadosas bases de datos desde los documentos de los archivos, que permitan comprender el conjunto, que haga visibles los movimientos y logros de las mujeres maestras a diferentes niveles, para comprender sus alcances como grupo socioprofesional, porque además es muy representativo de una historia social y cultural de las mujeres del resto de la sociedad, así es posible aprender de los avances en su condición de género, como colectivo. Asimismo buscar y ser escuchas de múltiples testimonios personales, para aproximarnos a la producción de subjetividades para develar los sentidos que las mujeres dan a sus estrategias personales y a sus acciones educativas.

10 Ver David L. Raby, Educación y revolución social en México (1921-1940), México, SEPSETENTAS, 1974, núm. 141, p.182, Es importante aclarar que Raby, no logra distinguir con claridad la violencia de género, señala que era natural tratar a las mujeres con violencia sexual en el México de la rebelión cristera. 


\section{Referências}

ACKER, Sandra. Género y educación, reflexiones sociológicas sobre mujeres, enseńanza y feminismo, Madrid, Narcea Ediciones, 2000.

CANO, Gabriela; OLCOTT, Jocelyn; VAUGHAN Mary kay (compiladoras). Género, poder y política en el México posrevolucionario, Fondo de cultura Económica, Universidad Autónoma MetropolitanaIztapalapa, México, 2009.

GALVÁN, Luz Elena; LÓPEZ PÉREZ, Oresta (coord.). Entre imaginarios y utopías: historias de maestras. San Luis Potosí, México. El Colegio de San Luis: Publicaciones de la casa Chata, 2008.

GALVÁN, Luz Elena; LÓPEZ PÉREZ, Oresta; SAN ROMÁN, Sonsoles (coords.). Primer Congreso Internacional sobre los procesos de Feminización del Magisterio, 21-23 de febrero, San Luis Potosí, México. El Colegio de San Luis, CIESAS y Univ. Aut. De Madrid. CD, 2001.

GALVÁN, Luz Elena. Soledad compartida. Una historia de maestros: 1908-1910, Ed. de la Casa Chata No. 28, México, CIESAS, 1991.

MELLO, Guiomar Namo de. "Mujer y profesionista" en Ser maestro: Estudios sobre el trabajo docente en Elsie Rockwell (comp.), México, SEPEl Caballito, 1985.

LÓPEZ PÉREZ, Oresta; HERNÁNDEZ, Marcelo, (Coords.). Presencia de las mujeres en la construcción histórica del normalismo rural en México durante el siglo XX, El Colegio de San Luis. (en prensa).

LÓPEZ PÉREZ, Oresta. Las maestras en la historia de la educación en México contribuciones para hacerlas visibles, en Sinectica, n. 28, 2008. Febrero-julio, pp. 4-16.

LÓPEZ PÉREZ, Oresta. Alfabeto y enseñanzas domésticas, el arte de ser maestra rural en el Valle del Mezquital. México, Colec. Antropologías CIESAS-CECAH, 2001.

LÓPEZ PÉREZ, Oresta. Que nuestras vidas hablen. Historias de vida de maestras y maestros indígenas tének y nahuas de San Luis Potosí, El Colegio de San Luis, 2018.

RABY, David L., Educación y revolución social en México (1921-1940), México, SEPSETENTAS, 1974. 
ROCKWELL, Elsie. Hacer Escuela, hacer estado. La educación posrevolucionaria vista desde Tlaxcala, COLMICH, CIESAS, CINVESTAV, 2007.

SCOTT, Joan. Historia de las mujeres. En Burke, Peter et al. Formas de hacer Historia, Madrid, España, Alianza Editorial, 1997.

VAUGHAN, Mary Kay. La politica cultural en la revolución, maestros, campesinos y escuelas en México 1930-1940, Biblioteca para la actualización del maestro, SEP, 2000.

VILLALPANDO, José Manuel Nava. Historia de la educación en México. Editorial Porra, México, 2a . Ed. 2012.

\section{Archivos}

Archivo Histórico de la Secretaría de Educación Pública. Fondo Dirección General de Educación Primaria en Estados y Territorios. (AHSEP/DGEPET) 


\title{
HISTÓRIA DA EDUCAÇÃO NO CENTRO MEMÓRIA VIVA DO INSTITUTO DE EDUCAÇÃO DA UNIVERSIDADE FEDERAL DE MATO GROSSO - UFMT/CAMPUS CUIABÁ
}

\author{
Nilce Vieira Campos Ferreira \\ Cleicinéia Oliveira de Souza \\ Nathalia Martins Luna
}

\section{Introdução}

Neste texto temos como objetivo analisar o processo de catalogação e arquivamento documental empregada no Centro Memória do Instituto de Educação - CMVIE ${ }^{1}$. No CMVIE temos por finalidade recolher, preservar e garantir o acesso aos documentos que foram produzidos e acumulados ao longo dos anos pelo Instituto de Educação, na Universidade Federal de Mato Grosso, no Campus Cuiabá, nos seus procedimentos administrativos, normas, rotinas de professoras, professores, servidoras, servidores, estudantes, o que exige esforço individual e coletivo para a preservação da memória institucional ${ }^{2}$.

No CMVIE o grupo de extensionistas, pesquisadores e pesquisadoras integrantes do Grupo de Estudos e Pesquisas em História da Educação, Instituiçóes e Gênero - GPHEG conhecem a importância da catalogação, arquivamento e cuidado que se deve ter com essa documentação. Nessa direção, procuramos trazer reflexôes sobre o processo de catalogação e arquivamento documental que realizamos no CMVIE.

Na perspectiva de Marc Bloch (2002), a história é uma ciência que se faz por meio de díspares métodos de pesquisa e técnicas, mas esclarece que "[...] uma ciência, entretanto, não se define apenas por seu objeto. Seus limites

1 A página do Grupo de Pesquisa e Estudos em História da Educação, Instituições e Gênero/ GPHEG que articula açóes de ensino, pesquisa e extensão pode ser consultada em https:// www1.ufmt.br/ufmt/un/cmvmt

2 O GPHEG conta com o apoio do Conselho Nacional de Desenvolvimento Científico e Tecnológico - CNPq, Brasil, para o desenvolvimento de suas pesquisas e atualmente está em andamento a investigação "Formação de Professoras Missioneiras nas Regiôes Centro-Oeste e Norte: Mato Grosso e Rondônia/Brasil (1936-1963)”, coordenado por Nilce Vieira Campos Ferreira, proposto para o triênio 2018-2021. 
podem ser fixados, também, pela natureza própria de seus métodos”. Para este autor, cabe "[...] perguntarmos se, segundo nos aproximemos ou afastemos do momento presente, as próprias técnicas da investigação não deveriam ser tidas por essencialmente diferentes. Isto é colocar o problema da observação histórica”. (BLOCH, 2002, p. 68).

No CMVIE, compreendemos que a história de uma instituição educativa não se faz só de acontecimentos do passado ou dos documentos cotidianos que ela produz, mas ela é construída diariamente, afinal "a memória emerge de um grupo que ela une" como dito por Pierre Nora (1993, p. 9), para quem a memória é viva, dinâmica. Podemos dizer que esse pensar dinamiza nosso centro: Centro Memória Viva do Instituto de Educação da UFMT, Cuiabá. Nora chama-nos a atenção ainda para fato de que a memória "é, por natureza, múltipla e desacelerada, coletiva, plural e individualizada". (NORA, p. 9, 1993).

Nesses tempos nos quais se concretiza a "película efêmera da atualidade", na qual "a história é o que nossas sociedades condenadas ao esquecimento fazem do passado porque levadas pela mudança”, como nos alerta Nora (1993, p. 8), nossas açóes no CMVIE se concretizam na dimensão de fortalecer o compromisso da instituição com as suas responsabilidades sociais e históricas.

No CMVIE pensamos que o valor que a academia dá ao seu passado deve ser tratado como um patrimônio a ser propagado e apropriado por todas e todos que por ele transitam. Nessa direção, o CMVIE pode ser compreendido inserido em um contexto mais amplo: o de colaborar ativamente na difusão de conhecimentos sobre a história institucional tanto para as pessoas que transitam entre seus muros quanto para a comunidade externa. Outro movimento inverso, contudo, ali também se origina: promover reflexóes a respeito de a história da instituição, revelando o que torna o CMVIE um espaço diferenciado e favorável ao estudo das memórias institucionais.

Um centro de documentação como o CMVIE tem, portanto, como objetivo central coletar a documentação existente em uma instituição, organizar essa massa documental com a finalidade de disseminar informaçóes e promover reflexóes sobre essa instituição, pensando sua trajetória e elaborando novos meios de utilizar e difundir o conhecimento, bem como trabalhar na concepção de que devemos produzir novos conteúdos que nos permita propagar nossos princípios e valores.

Há que se considerar ainda que o trabalho de documentação no acervo do CMVIE em busca de construir uma "memória" do Instituto de Educação da UFMT, exige competências distintas, mas complementares: um é mais técnico 
e o outro, mais analítico, fundamentado nas documentaçóes encontramos, catalogamos, disponibilizamos e analisamos em nossas pesquisas.

Retomando Bloch (2002), podemos comprovar a importância de documentos escritos para o trabalho de um historiador. Para ele, documentos podem despertar perguntas e hipóteses que precisam ser aclaradas, pois assim como outras fontes, documentos, ao mesmo tempo que contam uma história, podem ser manipulados de acordo com o propósito para o qual foram produzidos, estabelecendo uma interpretação equivocada de uma memória.

Isto é, precisamos olhar não apenas para as fontes, os dados, as informaçóes que o documento apresenta à primeira leitura, pois outras condiçóes são essenciais para sua compreensão, a exemplo, as condiçóes nas quais determinados documentos foram produzidos, em qual período, quem o produziu, entre outras. Há que se atentar, portanto, a uma metodologia que nos permita manter uma interlocução com o documento, pois como qualquer objeto de memória, ele pode ser manipulado de acordo com as vontades e interesses de quem ou de qual instituição o produziu.

Deveria ser supérfluo lembrar que, inversamente, os testemunhos mais insuspeitos em sua proveniência declarada não são, necessariamente, por isso, testemunhos verídicos. Mas antes de aceitar uma peça como autêntica, os eruditos se empenharam tanto em pesá-la em suas balanças que depois nem sempre têm o estoicismo de criticar suas afirmaçóes. A dúvida, em particular, hesita facilmente diante dos escritos que se apresentam ao abrigo de garantias jurídicas impressionantes: atos do poder ou contratos privados, por pouco que estes últimos tenham sido solenemente validados. (BLOCH, 2002, p. 96).

O documento é então uma ferramenta essencial no CMVIE, pois são essas fontes documentais que nos permitem um "fazer histórico". Ou seja, ao mesmo tempo no qual pesquisamos, criamos nossos escritos, aproximamonos da história da UFMT em seus primórdios e considerando a importância das fontes das quais dispomos, pensamos que "[...] tanto a memória individual quanto a memória coletiva são exploradas pelos arquivos e documentos. (HALBWACHS, 1990, p. 32). Assim vamos construindo o CMVIE naquilo que o constitui como acervo e como memória, e também vamos sendo construídas por esse "lugar de memória" ou por esse lugar de "uma história possível" nas palavras de Nora (1993, p. 11).

Informaçóes como as que são coletadas, organizadas e disponibilizadas no CMVIE não possuem, portanto, o papel exclusivo de apenas contar sobre 
a origem ou a história da instituição à qual elas se vinculam, todavia, essas informaçóes podem também atribuir respostas a questionamentos relacionados ao seu lugar naquela estrutura. Compreendemos que documentos não falam por si, eles estão lá nos centros de memória, é preciso chegar mais perto e analisá-los, uma vez que cada um "[...] tem mil faces secretas sob a face neutra e te pergunta, sem interesse pela resposta, pobre ou terrível, que lhe deres: trouxeste a chave?”. (DRUMMOND, 2012, p. 12).

Diante das informaçóes e documentos de que dispomos, convencemonos "[...] de que os lugares de memórias são antes de tudo restos [...]" (NORA, 1993, p. 12), sobras de uma história muitas vezes ignorada que vai compondo o acervo e nos possibilita uma articulação entre história e memória, na medida em que esses documentos coletados servem de base para nossas pesquisas nas quais precisamos analisar as questóes emblemáticas descritas nos documentos.

Consideramos que o perpetuamento de memórias desempenha um papel de importância nas sociedades funcionando, de certa forma, como um saber da sociedade sobre si mesma, mas esse perpetuamentos também é extremamente frágil, pois pode ser manipulado de acordo com os desejos daqueles que querem compor e manter viva uma memória de glória ou supremacia sobre um determinado povo ou nação, o que cria condiçóes adequadas para o surgimento de regimes totalitários ou nacionalismos exacerbados em sua forma de compreensão do pertencimento do homem, isto por que "[...] para algumas lembranças reais junta-se assim uma massa compacta de lembranças fictícias [...]”. (HALBWACHS, 1990, p. 32).

Uma característica simples, mas decisiva do CMVIE, o delineia como um espaço de memória na UFMT. Neste lugar de memória somos responsáveis pela coleta, catalogação, guarda, preservação e fruição de nossa história e patrimônio cultural, cujas memórias podem nos permitir “[...] atualizar impressóes ou informaçóes passadas ou que ele representa como passadas [...]”. (LE GOFF, 1990, p. 366).

Concordamos, como dito por Le Goff (1990), que a memória, portanto, não é um fator unicamente social ou subjetivo, mas também psicológico, pois essas memórias só farão sentido para indivíduos da mesma sociedade, que compartem de uma herança comum a eles, isto é, esses pressupostos náo se distanciam, uma vez que memórias são construídas de acordo com a interpretação subjetiva de cada pessoa. Sobretudo, ainda que essas memórias sejam coletivas, elas não se eximem das interpretaçôes individuais, 
sujeitas a subjetividade de cada um, o que, portanto, para sua permanência uma memória necessita '[...] refazer-se constantemente, pois a memória está ora em retraimento, ora em transbordamento'. (LE GOFF, 1990, p. 368).

No CMVIE, partilhamos ainda a concepção de que o documento oferece visóes de mundos peculiares e hoje pensamos que nele organizamos uma memória do Instituto de Educação da UFMT que se encontrava dispersa. Isso, além no permite também uma escrita dinâmica de sua história, pois os documentos que ali estão podem "[...] falar e também pode silenciar, esconder, distorcer e abrigar dados que podem ser percebidos por lupas que são produzidas por meio de problemas, perguntas, cruzamentos e outras iniciativas necessárias a esse trabalho". (VALDEZ, 2015, p. 24).

Nessa concepção, pensamos que a memória coletiva e pedagógica das práticas desenvolvidas por professores e estudantes ali armazenada possa se tornar também memória histórica.

\section{Lugar de memória na UFMT: o Centro Memória Viva do Instituto de Educação - CMVIE}

Tomemos agora o histórico do Centro Memória Viva do Instituto de Educação - O CMVIE que surgiu a partir da criaçáo do Centro Memória Viva do Centro Oeste - CMV, em 2011, que tinha a intenção de organizar centros de documentação a respeito de a educação de jovens e adultos brasileiros, cujos procedimentos que adotamos têm "[...] o objetivo de reunir, em ambiente virtual, a catalogaçáo do material identificado pelos pesquisadores, visando disponibilizar acesso ao público para consulta on line." (RODRIGUES, 2016, p. 1).

Incialmente constituído como Centro de Referência em EJA, o CMV surgiu, assim, de uma articulação entre pesquisadores das universidades federais da regiáo Centro-Oeste.

No Centro-Oeste conseguimos construir o Centro de Referência em EJA, numa articulação entre os pesquisadores das universidades federais de Goiás, Mato Grosso, Mato Grosso do Sul e de Brasília, da Região Centro-Oeste, mobilizados pela Professora Maria Margarida Machado, que passou a coordenar esta rede de pesquisa, para a construção de uma proposta unificada. Esta rede de pesquisa do Centro-Oeste denominou-se: Centro Memória Viva - Documentação e Referência 
em Educação de Jovens e Adultos, Educação Popular e Movimentos Sociais do Centro-Oeste, por compreender que a EJA, educação popular e movimentos sociais envolviam as temáticas abordadas na modalidade, bem como nos campos do ensino, pesquisa e extensão vinculados à EJA desenvolvidos na Universidade. (RODRIGUES, 2016, p. 4).

Em 2014, com o intuito de organizar o acervo documental do Instituto de Educação -IE, na UFMT, campus Cuiabá, começamos a organizar o CMVIE. O projeto foi e é apoiado pela Pró-reitoria de Cultura, Extensão e Vivência - PROCEV e pela Coordenação de Extensão - CODEX. A professora coordenadora do Projeto conta com bolsistas de extensão que são responsáveis pela catalogaçáo manual, tombamento patrimonial e catalogação das fontes documentais que foram encontradas e disponibilizadas pelos departamentos do $\mathrm{IE}^{3}$. O CMVIE conta ainda com a colaboração de pesquisadoras e pesquisadores que desenvolvem seus projetos de mestrado, doutorado e pós-doutorado.

Compreendendo que "[...] a memória, essa operação coletiva dos acontecimentos e das interpretaçóes do passado que se quer salvaguardar, se integra, como vimos, em tentativas mais ou menos conscientes de definir e de reforçar sentimentos de pertencimento e fronteiras sociais [...]" como dito por (POLLAK, 1989, p. 9).

Desse modo, o CMVIE contribui para a salvaguarda da memória que compóe a cultura e a história do Instituto da Educação da Universidade Federal de Mato Grosso, UFMT, Cuiabá e pensamos que se faz necessário conservar os vestígios que a história e a memória deixaram, como uma forma de evitar o efeitos devastadores de uma sociedade do tempo presente que pouco valoriza a história e memória institucionais. Tratamos assim de catalogar esse tesouro da UFMT para outras e outros, historiadores e pesquisadores que militam no campo da memória.

Basicamente o que constitui o CMVIE são as atividades de extensão, de ensino e de pesquisa. As atividades de pesquisa relacionadas à História da Educação são feitas pelo Grupo de Estudos e Pesquisa em História da Educação, Instituiçóes e Gênero - GPHEG.

Com isso, configuramos a principal finalidade do CMVIE, a nosso ver:

3 Projeto Centro Memória Viva do Instituto de Educação - CMVIE - registrado no Sistema de Extensão da UFMT- SIEX: 270220191009151355. O projeto é coordenado pela Profa. Dra. Nilce Vieira Campos Ferreira. 
a preservação, cuidado e manutenção de um acervo que possibilite a consulta de diversos pesquisadores aos catálogos e pastas disponíveis naquele lugar de memória. Esse acervo possibilita um contato direto com a história da instituição e da educação. Para isso, contamos com a presença de pesquisadores e extensionistas para a recepção de interessados e para organização dos catálogos e ajuda para a consulta desses documentos.

Extensionistas, principais responsáveis pela organização do acervo, procedem à catalogação manual e eletrônica. Em um primeiro momento, entram em contato físico com o documento, analisam aspectos como autor, título, ano, assunto, classificação e número de páginas do documento que têm em mãos. Essas informaçôes, ainda que básicas, são muito importantes para um primeiro conhecimento para classificação desse documento.

Logo após a catalogação manual, extensionistas iniciam a catalogação eletrônica que consiste na transferência dos dados feitos na primeira etapa para uma ficha técnica, na qual constará as informaçóes relacionadas ao documento em um veículo eletrônico. Depois do processo de catalogaçáo se faz o tombamento, dando-lhe um número no sistema. As capas com as indicaçóes do documento são feitas e anexadas ao documento, encerrando o processo de catalogaçáo desse documento e o arquivando em pastas que poderão ser consultadas.

No CMVIE adotamos o Programa Biblivre ${ }^{4}$ para catalogar a documentação de que dispomos. Esse Programa é um acervo direcionado a catalogação de documentos, utilizado por instituiçôes públicas, privadas e bibliotecas. O sistema Biblivre é uma ferramenta que também está aberta ao público para acesso online de caráter gratuito. Essa documentação é catalogada dentro do programa utilizando uma ficha contento informaçóes a respeito de o documento, sendo preenchidas e arquivando-as no sistema. Logo após essa catalogaçáo, gera-se o tombo do documento, procedimento importante para a localização do documento catalogado dentro das pastas e do programa.

$\mathrm{Na}$ figura 1 visualizamos as etapas do registro no sistema, preenchendo o título do documento, classificado de acordo com a origem do documento, o ano e o número de páginas.

4 O Biblivre é um software livre, portanto gratuito, para gerenciamento de bibliotecas e de acervos. Este software permite a catalogação de recursos informacionais variados e sua disponibilização em catálogo. O programa pode ser conhecido e baixado aqui http://www.biblivre.org.br/index. $\mathrm{php/sobre-biblivre/o-programa}$ 
Figura 1 - Ficha de Registro Biblivre.

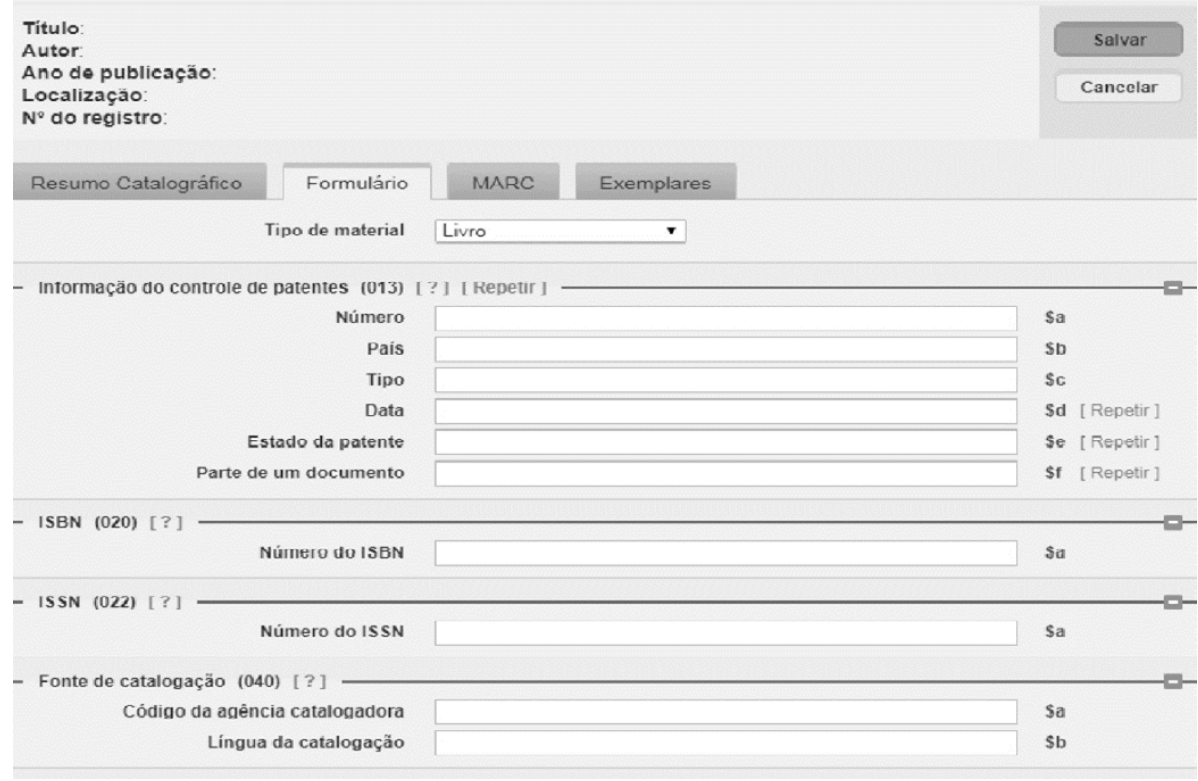

Fonte: Programa Biblivre.

Com isso, a documentação do Instituto da Educação da UFMT constante no CMVIE pode ser disponibilizada à comunidade acadêmica e a outras pessoas interessadas que têm o interesse em pesquisar um documento específico, caso esse documento conste no acervo. Esse cuidado com a catalogaçáo e disponibilização das fontes é essencial para a compreensão do documento como uma herança material importante para a pesquisa e compreensão da história do documentação do Instituto da Educação e da UFMT como um todo.

$\mathrm{Na}$ figura número 2, vemos a tela os dados referentes às informaçóes constantes no documento, tais como sua edição, o nome do autor, a área de conhecimento correspondente do documento. Essas informaçóes precisam ser preenchidas para tornar a busca por um exemplar mais clara e objetiva. 
Figura 2 - Ficha de registro Biblivre.

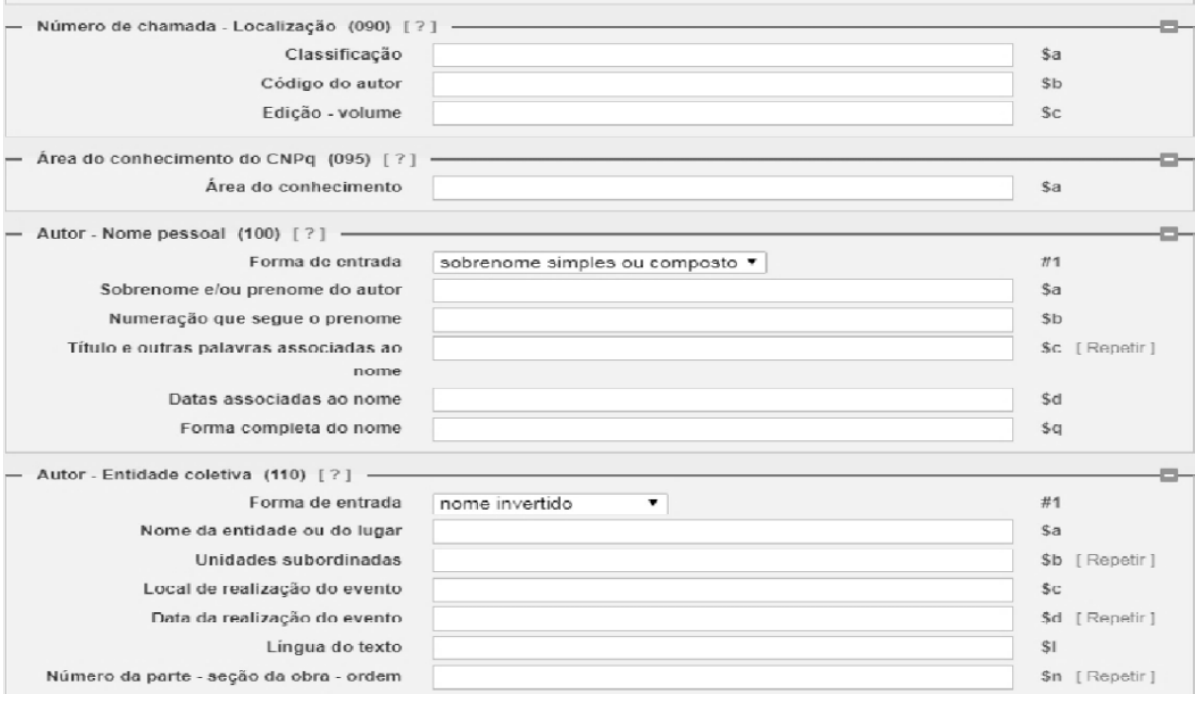

Fonte: Programa Biblivre.

$\mathrm{Na}$ figura 3, são apresentadas as últimas etapas para gerar o número de registro do documento. Logo após o preenchimento completo das informaçóes necessárias, é preciso clicar na ferramenta "salvar" para finalizar a operação. Essas informaçóes permitem que a pesquisadora ou o pesquisador encontrem aquilo que procuram com maior facilidade. 
Figura 3 - Ficha de Registro.

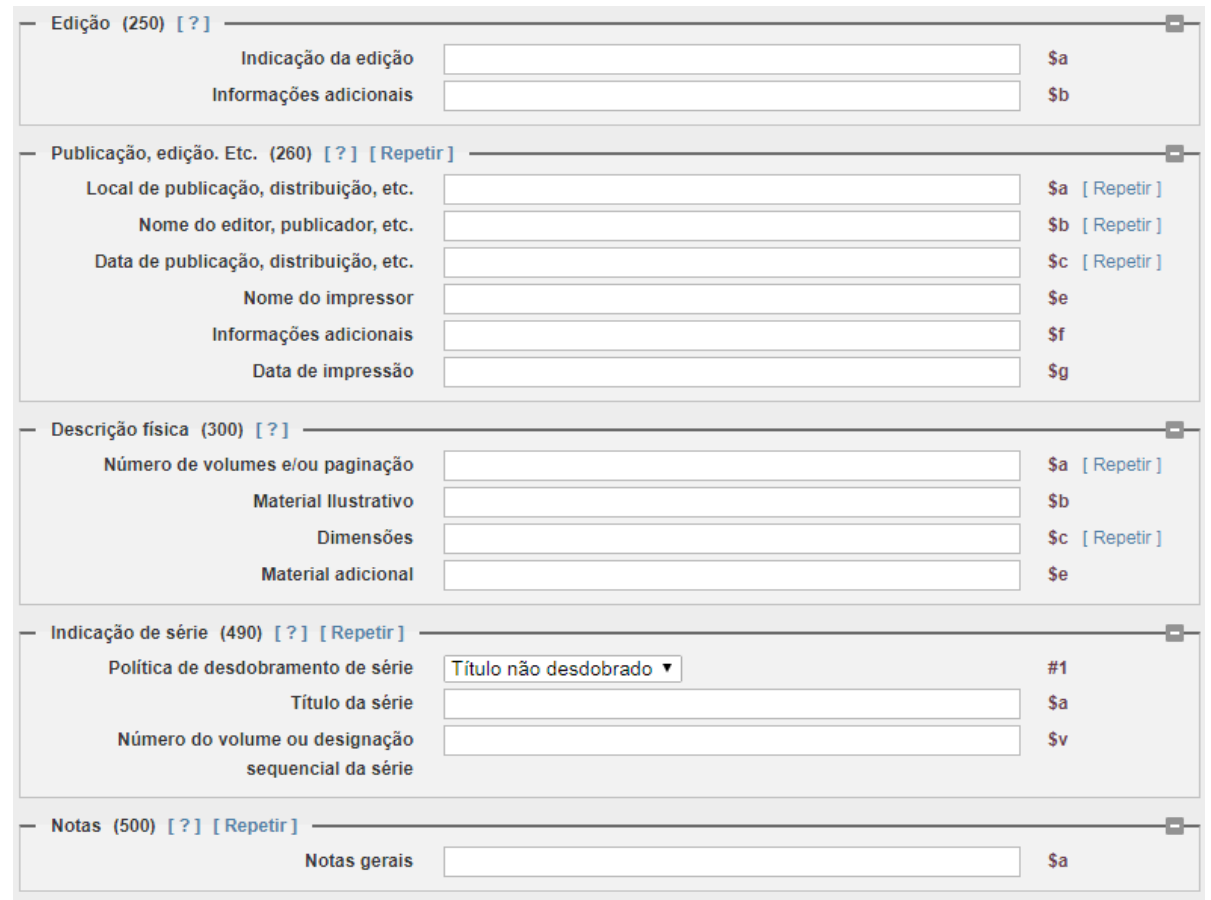

Fonte: Programa Biblivre.

Podemos perceber, portanto, a partir das figuras apresentadas que o sistema Biblivre permite e facilita a organizaçáo dos documentos que compóem o acervo do CMVIE, tornando acessível a pesquisadoras e pesquisadores o acesso à massa documental do Instituo de Educação. Esse sistema auxilia não apenas extensionistas, mas também a instituição que pode conhecer seu acervo, identificar, manter o controle e disponibilizar o acesso à documentação existente. $\mathrm{O}$ fato de ser um sistema de acesso livre e gratuito é também um fator que mobilizou sua utilização no CMVIE.

\section{O Centro Memória Viva: um acervo e seus projetos}

Márcia do Santos Ferreira e Nilce Vieira Campos Ferreira (2016) descreveram que o CMVIE é mais do que apenas um acervo instituído e afirmaram que o lugar de memória resulta de um projeto responsável pela permanência dos projetos de extensáo voltados pela área de Educação e pesquisa no Instituto de Educaçáo da UFMT e, de forma mais abrangente, nas 
instituiçóes escolares, uma vez que está diretamente vinculado às atividades de ensino, pesquisa e extensão que a equipe GPHEG vem desenvolvendo.

No CMVIE, buscamos uma perspectiva diferente para extensionistas, pesquisadoras e pesquisadores, voltando-nos também para problemas sociais e buscando soluçóes para um grupo de pessoas que se voltam para a defesa de perspectivas de trabalho voltados à memória das instituiçóes escolares e como forma de socializar as informaçóes disponíveis.

\begin{abstract}
Encontramos esses propósitos expressos nos objetivos apresentados no regimento interno do programa: a) propiciar condiçóes para o desenvolvimento de análises sobre a Educaçáo visando ao aprofundamento e à sistematização de alternativas para o sistema educacional; b) socializar a produção científica no setor da Educação mediante formas diversificadas de participação e divulgação do saber; c) propor mudanças construtivas à sociedade brasileira $\mathrm{e}$ mato-grossense, no que se refere à educação, à ciência e à cultura. (FERREIRA; FERREIRA, 2016. p. 79).
\end{abstract}

Para Ferreira e Ferreira (2016) esse é um projeto que proporciona um envolvimento maior com a sociedade externa, abrindo as portas da instituiçáo para as vozes daqueles que precisam falar e que se encontram nos registros documentais. O CMVIE ao compartilhar e difundir essa documentação, cumpre com a finalidade de reunir extensionistas, pesquisadoras e pesquisadores com o intuito de construir um legado documental ético e de importância tanto para o GPHEG quanto para a comunidade acadêmica e seu entorno.

O Centro Memória Viva (CMV), como já foi ressaltado, disponibiliza ao pesquisador uma série de fontes referentes à história da educação de jovens e adultos, possibilitando diversos estudos e pesquisas. Além de privilegiar documentos regionais, de instituiçôes públicas e privadas, esse espaço abriga ainda acervos documentais de um outro estado da regiáo Centro-oeste (Mato grosso). (VALDEZ, 2015, p. 23).

De acordo com Valdez (2015), o Centro Memória Viva (CMV/GO) serviu como base para a criação do CMVIE do Instituto de Educação da Universidade Federal de Mato Grosso, sendo referência para o conceito de formação do arquivo. Esse Centro de Memória Viva também foi responsável por abrigar documentos dos acervos documentais da regiáo Centro-Oeste.

Ressaltamos que o GPHEG, grupo ao qual o CMVIE está articulado, congrega pesquisadoras, pesquisadores e extensionistas que militam no âmbito da história educacional mato-grossense. O grupo se volta para os estudos da história das instituiçóes educacionais no período republicano, 
história do ensino rural e das instituições rurais e urbanas nos níveis primário, secundário e superior; história da educação popular com destaque para o contexto da educação de jovens e adultos; história da educaçáo feminina na perspectiva da história das instituiçóes educativas; gênero e relaçóes entre escolarização e corpo, estabelecendo diálogos com a história da educação das regióes Centro-Oeste e Norte brasileira ${ }^{5}$.

$\mathrm{Na}$ Coordenação de Extensão da UFMT - CODEX, foram aprovados no ano de 2018, O Programa Permanente de Extensão: açóes educativas para o protagonismo feminino - vozes das mulheres na UFMT/Cuiabá, PBEXT AÇÓES 2018 e o Projeto Centro Memória Viva Mulheres na Educação de Jovens e Adultos -EJA - PBEXT Açóes Afirmativas 2018, em funcionamento desde o ano de 2015. Os programas e os projetos contam com bolsistas de extensão. Constituem programas e projetos de extensão consolidados e organizados com o intuito de compor um acervo no IE que também destaquem o protagonismo feminino no âmbito da UFMT e por extensão, em Mato Grosso.

Para além das atividades de pesquisa e de organizaçáo de acervos, $\mathrm{O}$ CMVIE vem desenvolvendo açóes em escolas da comunidade cuiabana e participa de reunióes, fóruns e outros em departamentos e instituiçóes públicas para divulgar a importância dos acervos escolares. A participação em açóes ligada à educação de jovens e adultos, bem como educação e participação das mulheres é também uma ação recorrente dos projetos de extensão e de pesquisa do CMVIE, com o intuito de manter um contato entre as várias instituições de educação e de projetos de inserção de jovens e adultos - EJA e das mulheres nos espaços educacionais e em outros espaços públicos.

Os projetos têm como objetivo final produzir memória acerca das histórias dessas pessoas, tanto da EJA quanto de mulheres. Com foco na história das mulheres e da EJA, o CMVIE investiga, cataloga, analisa e disponibiliza estudos, pesquisas e documentos de histórias de vida, trajetos e mesmo a busca pelo acesso ao conhecimento. Com isso, construímos um lugar de memória no qual temos um inventário sobre o Instituto de Educação da UFMT e de temáticas afins, pesquisas que são desenvolvidas nos cursos de mestrado, doutorado, pós-doutorado e por extensionistas, entre outras atividades.

Destacamos que o acervo documental do CMVIE se encontra na sala 321, 3o piso do Instituto de Educação da Universidade Federal de Mato Grosso. Outros documentos se encontram no setor de arquivos, na sala 11, no Serviço de Psicologia - SPA, dado o pouco espaço físico da sala 321 que

5 Ver: https://wwwl.ufmt.br/ufmt/un/cmvmt 
não comportou toda a massa documentação, o que demandou que parte do acervo fosse organizado na sala 11, no Serviço de Psicologia - SPA.

Cabe mais uma vez recordar que o CMVIE não procura apenas ser um centro de organização e armazenamento desses documentos, mas também busca ser um espaço para o acesso de pesquisadoras, pesquisadores e extensionistas aos documentos que guardam e carregam a memória de uma instituição, com uma linha de pesquisa mais humana e mais subjetiva, ou seja, o CMVIE é mais um meio de dar voz aos documentos que ali se encontram.

Com a localização, coleta, tratamento, organização e sistematização dos documentos localizados vamos apreendendo e viabilizando à comunidade acadêmica e àquelas e aqueles que a ela se articulam, o trabalho desenvolvido em um acervo institucional, de modo a propiciar que essa herança documental possa se tornar conhecida por quem transita pela UFMT.

No CMVIE, há documentos como planos de aula, diários de aula e outros documentos relacionados às escolas mato-grossenses. Ferreira (2014, p. 29) descreveu que as práticas cotidianas de uma instituição escolar são "expressão da historicidade e dos processos de continuidade de seu processo evolutivo”. Essas práticas cotidiamente registradas nos diárias de aula, nos planos de aula que temos no CMVIE podem contribuir para o registro da memória e funcionalidade do Instituto de Educação, nos níveis local e regional, permitindo-nos compreender as razóes de sua existência.

O horário de funcionamento ocorre no período matutino e vespertino, de segunda-feira à sexta-feira, oferecendo consulta a quem precisa buscar por um documento específico do Instituto de Educação ou da Universidade Federal de Mato Grosso. O acesso a essas informaçóes também pode se dar em: https://www1.ufmt.br/ufmt/un/cmvmt

\section{Entre o início e seguindo em frente: algumas considerações sobre o CMVIE}

O projeto CMVIE tem seu início marcado pela articulaçáo com o Centro Memória Viva do Centro-Oeste - CMV e para a formação de seu acervo encontrou referências no Centro Memória Viva de Goiás - CMV/GO.

Contando com um acervo significativo que contém parte da história de docentes, discentes, diretoras, diretores, pesquisadoras e pesquisadores, entre outras pessoas que produziram documentos materiais para a educaçáo matogrossense, o CMVIE se torna um lugar de memória para a própria UFMT e para a comunidade em seu entorno. 
Temos a compreensão de que o CMVIE pode tornar a história do Instituto de Educaçáo menos comum, levando a um número maior de pessoas o acesso às fontes documentais que são relevantes para a memória institucional da UFMT e do próprio ensino superior no estado de Mato Grosso. Nessa compreensão, o CMVIE garante que a memória produzida no âmbito institucional possa ser acessada pela comunidade acadêmica e seu entorno, bem como a outros que a esse centro de documentação queiram ser admitidos.

O arquivo se empenha e cresce cada vez mais, formando um acervo de relevância para aquelas e aqueles que se empenham em garantir a conservaçáo e disponibilização desses documentos, de modo a colaborar ativamente na difusão de conhecimentos a respeito de sua história institucional.

Mesmo em meio à problemas enfrentados pelos arquivos e pelos acervos escolares, a equipe do CMVIE volta seu olhar para a coletividade e para a conservação das fontes documentais e, portanto, para este lugar de memória institucional, em busca de a construçáo de uma memória coletiva voltada para as diversas problemáticas relacionadas à educaçáo mato-grossense e de como as instituiçôes educativas no estado lidaram e lidam com essa memória compartilhada e construída por aqueles que estiveram e estão nos espaços escolares.

O acervo do CMVIE, ao catalogar e disponibilizar documentos do IE, na UFMT, compreende que os documentos, mesmo um memorando ou um ofício, carregam em si uma história, cuja importância destaca um tempo e espaço da memória institucional, o que nos parece, consolidas a importância dos acervos institucionais em busca da manutenção da memória material e documental. Para além disso, o CMVIE compóe uma rica herança, de importante valor para as geraçôes futuras, ao construir uma rede compostas por extensionistas, pesquisadoras e pesquisadores de identidades diferentes, mas compondo uma organizaçáo consciente de si mesma, desse espaço e lugar de memória coletiva da Universidade Federal de Mato Grosso.

\section{Referências}

ANDRADE, Carlos Drummond de. Procura da Poesia. In: A rosa do povo. São Paulo: Companhia das Letras, 2012.

BIBLIVRE. Disponível em http://biblivre.org.br/. Acesso em: 10 de agosto 2018.

BLOCH, Marc. Apologia da história ou o ofício do historiador. Rio de Janeiro: Jorge Zahar, 2002. 
FERREIRA, Nilce Vieira Campos et al. As pesquisas em história da educação no Programa de Pós-Graduação em Educação da UFMT Campos Cuiabá. In: DUARTE, Aldimar Jacinto; TIBALLI, Elianda Figueiredo Arantes. (orgs.). Pós-graduação e Pesquisa em Educação: contradiçóes e desafios para a transformaçáo social. Goiânia - Goiás: Editora da PUC Goiás. 2016.

FERREIRA, Nilce Vieira Campos. Economia doméstica: ensino profissionalizante feminino no Triângulo Mineiro (Uberaba/MG- 19531997). Ed. Paco Editorial: Jundiaí, 2012.

HALBWACHS, Maurice. A memória coletiva. Prefácio Jean Duvignaud. Tradução: Laurent Léon Schaffter. São Paulo: Editora Revista dos Tribunais LTDA. 1990.

LE GOFF, Jacques. História e memória. Tradução: Bernardo Leitão et al. Sáo Paulo: Editora Unicamp, 1990.

NORA, Pierre. Entre memória e história: a problemática dos lugares. Tradução: Yara Aun Khoury. Projeto História. São Paulo, v. 10, p. 7-28, dez. 1993.

POLLAK, Michel. Memória, esquecimento, silêncio. Estudos Históricos. Rio de Janeiro, v. 2, n. 3, p. 3-15, 1989.

RODRIGUES, Maria Emilia de Castro. Centro Memória Viva Documentação e Referência Em EJA, Educaçáo Popular e Movimentos Sociais do Centro-Oeste. Jataí, V Congresso Internacional de História. 2016. Disponível em: http:/www.congressohistoriajatai.org/2016/resources/ anais/6/1477811969_ARQUIVO_CMV_textocompleto_final.pdf. Acesso em: 10 maio de 2018.

MACHADO, Maria Margarida. (orgs.). A História guardada no Centro Memória Viva: educaçáo de Jovens e Adultos, educação popular e movimentos sociais. Goânia: Cânone editorial, 2015.

VALDEZ, Diane. Beber diretamente da fonte: os documentos apontam, sussurram, silenciam, denunciam, revelam e proporcionam a escrita da história. In: VALDES, Diane; RODRIGUES, Maria Emília de Castro; MACHADO, Maria Margarida. (orgs). A História guardada no Centro Memória Viva: educação de Jovens e Adultos, educação popular e movimentos sociais. Goânia: Cânone editorial, 2015. 


\title{
MEMÓRIAS SOBRE O RECRUTAMENTO DE PROFESSORAS RURAIS PIONEIRAS DO SUL DE RONDÔNIA NO SEGUNDO QUARTEL DO SÉCULO XX
}

\author{
Marcia Jovani de Oliveira Nunes \\ Josemir Almeida Barros
}

\section{Introdução}

No final dos anos 70 do século XX o Território Federal de Rondônia (atual estado de Rondônia) vivenciava o período do seu terceiro fluxo migratório, originado pela abertura da BR 364, trazendo para a região agricultores da região sul, sudeste e centro oeste, que vinham atraídos pelo anúncio de terras férteis e dos projetos de assentamento e colonizaçáo oferecidos pelo Instituto Nacional de Colonização e Reforma Agrária. (INCRA).

Com o projeto de colonizaçáo, surge o município de Colorado do Oeste, localizado ao Sul do Estado de Rondônia, tem população atual de aproximadamente 18.591 habitantes segundo dados do Instituto Brasileiro de Geografia e Estatística (IBGE) e foi criado pela Lei 6.921 de 16 de junho de 1981, sua origem está diretamente ligada a implantação do PIC-PAR ${ }^{1}$.

De acordo com dados do IBGE por volta de 1973 chegaram as primeiras famílias na região e fixaram-se às margens do rio Colorado, iniciando o processo de colonização municipal. Cerca de $60 \%$ da população residia na zona rural, neste contexto começam a surgir as primeiras escolas rurais. A inexistência de profissionais qualificados e políticas públicas voltadas às necessidades e especificidades da educação, agravavam-se ainda mais nas escolas de localidades rurais. No Estado de Rondônia, o governo de Jorge Teixeira de Oliveira, não tinha mão de obra qualificada para o magistério em número suficiente, portanto, acabava por contratar professores leigos para o exercício do magistério (LIMA, 1997).

A presente investigação discorre sobre o processo de contratação e de formaçáo em serviço dos professores rurais dos anos 80 do século XX com vistas a intervir no cenário atual da educação rural do município de Colorado do Oeste - RO. O principal objetivo da pesquisa foi identificar e

1 PIC-PAR - Projeto Integrado de Colonização Paulo Assis Ribeiro foi criado pela Portaria do INCRA n ${ }^{\circ} 1480$, de 10 de outubro de 1973, sendo realmente implantado a partir de 1974. 
analisar o processo de recrutamento, seleção e a formação inicial dos professores ingressantes na carreira do magistério no final dos anos 70 e início dos anos 80 do século XX no município de Colorado do Oeste - RO.

O estudo da história da educação e da pedagogia é imprescindível ao conhecimento da educação atual, pois esta é um produto histórico e, não, invenção exclusiva de nosso tempo. A educaçáo presente é, com efeito, do mesmo passo, fase do passado e preparaçáo do futuro. É como um corte transversal que se fizesse no intérmino evolver histórico da educação. (LUZURIAGA, 1978, p. 9).

Quando a pesquisa se propóe estudar a história da educação, o passado não se apresenta como algo estático e morto, mas "como explicação do estádio atual”, uma possibilidade para compreender e fundamentar o presente, "constitui excelente meio de melhorar a educação atual, porque nos informa das dificuldades que as reformas da educação tem encontrado, dos perigos das ideias utópicas, irrealizáveis, e das resistências anacrônicas, reacionárias, que a educação tem experimentado.” (LUZURIAGA, 1978, p.9).

Para Nosella; Buffa (2009, pp. 71-72) "o pesquisador estuda e reconstrói o passado numa perspectiva cultural de valores atuais e assim avalia pessoas e instituições", este estudo permite descrever valores internos e culturais que são próprios deste grupo no passado e que podem contribuir para a compreensão do cenário atual do novo grupo.

Le Goff (1990) acrescenta que assunção da história social do grupo contribui para a formação de sua identidade. Vieira, Peixoto; Khoury (1991, p.27) afirmam que "faz parte do exercício do poder ocultar as diferenças, a contradiçáo, decidindo o que deve ser lembrado, como deve ser lembrado e, em contrapartida, o que deve ser esquecido". Desta forma, a partir do estudo distinto entre os dois contextos (passado e presente) é possível realizar uma aproximação que integre esses dois níveis possibilitando o entendimento do ambiente para aqueles que hoje estáo inseridos no contexto, criando uma nova realidade que seja rica em sentidos.

Para Nosella; Buffa (2009, p. 84) "tais pesquisas elevam nos educadores o nível de responsabilidade pelos seus atos e estimula nos leitores o gosto pelos estudos da história local e nacional”. Grazziotin; Almeida (2012) coadunam que é o conhecimento das diversas singularidades que existem em cada canto do país que permite compreender o que foi e se tornou hoje a educação brasileira. Apontam que o estranhar dessa realidade na qual está inserida é o grande desafio do pesquisador contemporâneo, que tem como missão desviar-se dos 
paradigmas globalizantes e revelar as particularidades locais a partir do reconhecimento das especificidades que tornam original cada época e lugar.

Galvão; Lopes (2010) afirmam que, apesar das transformaçóes, pelas quais a escola passou ao longo dos tempos alguns elementos e práticas remetem ao século anterior, portanto para se entender os problemas que enfrentamos na escola atualmente, é necessário estudar e compreender o passado da educação, e que essa percepção possibilita intervençóes conscientes e objetivas no futuro.

Vieira, Peixoto; Khoury (1991) destacam a importância do estudo do cotidiano e afirmam que não existe nada mais ilustrador e explicativo para a compreensão das relaçóes sociais. Galvão; Lopes (2010) corroboram que tem aumentado significativamente o número das pesquisas que buscam retratar o contexto cotidiano da prática escolar nos séculos XIX e XX, seja para retratar o momento da institucionalização da escola no Brasil, seja para evidenciar a inércia da prática escolar na história da educação.

Portanto, a partir destes pressupostos e considerando o contexto local esta pesquisa teve a intenção de contribuir com a compreensão da história da escolarização brasileira na região norte, tendo em vista a transformação da realidade atual a partir do debate teórico-metodológico. Dessa maneira, buscou-se retratar criticamente a história da educação no interior do estado de Rondônia, pois acredita-se que o conhecimento e assunção da história pode nos instruir sobre o que e como fazer.

Esta é uma pesquisa de abordagem qualitativa que utilizou como metodologia a pesquisa bibliográfica de autores que problematizam a educação, a história da educação em Rondônia e a história de Rondônia durante os anos que precederam e acompanharam a constituição do estado no final dos anos 70 e início dos anos 80 do século XX.

Foi realizada a pesquisa de campo com o objetivo de coletar os dados empíricos das fontes diretas, cinco professoras ${ }^{2}$ que vivenciaram o magistério neste período. Para coleta de dados seguiu-se as orientaçóes de Nosella; Buffa (2009) e Galvão; Lopes (2010) quanto a aplicação de entrevista semidiretiva realizada através de questionário. Para realização das entrevistas foram observadas as orientaçóes de Bardin (2011) e Meihy (2005), que consistiram em gravar, arquivar, ouvir e transcrever integralmente os diálogos.

$\mathrm{Na}$ etapa de análise das entrevistas seguiu-se as orientaçóes de Nosella; Buffa (2009), Bardin (2011) e Grazziotin; Almeida (2012) agrupando-se os dados

2 As professoras que participaram da pesquisa autorizaram a identificação e publicaçáo dos fragmentos de suas entrevistas por meio do aceite e assinatura do Termo de Consentimento Livre Esclarecido-TCLE apresentado no ato de cada entrevista. 
relevantes em categorias e subcategorias. Em seguida, foi realizada a análise de conteúdo clássica, elaborando-se um quadro categorial, que privilegiou a repetição e frequência temática.

De acordo com Cunha (1997, p.2) "as apreensôes que constituem as narrativas dos sujeitos são a sua representação da realidade e, como tal, estáo prenhes de significados e reinterpretaçóes". Assim, não se trata de buscar comprovar ou negar uma história, porque todas as histórias são verdades do ponto de vista de quem as vivenciou e sentiu na pele cada situaçáo, portanto pretendemos seguir "respeitando a inteligência de quem lê e as versóes dos envolvidos”. (PERES, 2015, p. 26).

\section{"Viemos para Rondônia"}

O historiador Gomes (2013) conta que a abertura da BR 029, atual BR 364, conhecida também como "estrada das onças", foi um marco para a colonização do Território Federal do Guaporé. Com a abertura da principal "artéria" do estado uma gigantesca migração ocorreu, vieram milhares de famílias, a maior parte do sul do Brasil, buscavam a "terra prometida". Lima (1980) afirma que o contínuo fluxo migratório trouxe relevantes transformaçóes econômicas, políticas e sociais para Rondônia. Para Peres (2015, p.50) "nada foi mais decisivo para a ocupação do território do Guaporé que a BR 364, concluída em 1968 e asfaltada definitivamente em 1984 [...]. A estrada determinou o padrão da distribuição de terras e franqueou a mãos privadas o acesso a uma região inexplorada”.

Neste contexto de processo migratório as professoras colaboradoras desta pesquisa, pioneiras da educação, chegaram ao município de Colorado do Oeste - RO. No entanto, elas ainda nem sabiam que seriam professoras. Nas entrevistas relataram que chegaram ao Território Federal de Rondônia em meados dos anos de 1970. Todas as entrevistadas eram da região Sul do país, especialmente do Paraná e vieram muito jovem acompanhando suas famílias, geralmente por uma decisão tomada pelos pais ou maridos.

A realidade que as pioneiras da educaçáo encontraram nas terras do Sul rondoniense distinguia-se muito de seu local de origem. Havia muita necessidade, escassez e dificuldades em todos os aspectos. Gomes (2013, p.2) afirma que "as pessoas que buscavam um pedaço de terra para sua sobrevivência foram motivadas a se instalarem na Amazônia Rondoniense sem a estrutura básica necessária”. O 1º Plano de Educação destaca que o setor de Educação na década de 70 foi obrigado a enfrentar, além dos múltiplos problemas comuns 
à educação da época, os desafios específicos da Amazônia Legal, tais como: "uma regiáo onde o acesso é difícil, escassos os recursos humanos qualificados e imensas as carências sócio-educacionais da população”. (LIMA, 1980, pp. 5-6).

Segundo Gomes (2013, p.3), o primeiro governador do Estado de Rondônia, Teixeirão, em sua posse disse: "Venham brasileiros de todo o Brasil, venham gente de todos os povos. Rondônia oferece trabalho, solidariedade e respeito. Tragam seus sonhos, anseios e ilusóes, compartilhem tudo isso com este povo admirável, assumam com ele os problemas e as dificuldades naturais na trajetória em busca do grande destino do Brasil.”

A professora Missiatto, M. L. (2018) nos confirma que havia a pouco se casado, nasceu e viveu em Apucarana-PR e veio para Colorado do Oeste em 1978, deparou-se com muitas dificuldades logo de início.

Em 1978 após dois anos de casados viemos para Rondônia, era muito mata, não tinha água, a gente tinha que carregar longe, aqui dentro dessa matinha tinha uma mina muito bonita, era uma pedra, que minava água limpa, todas as famílias vinham para pegar água limpa da mina. (MISSIATTO, Maria Lúcia. Colorado do Oeste - RO, 08 de maio 2018. Entrevista concedida à Marcia Jovani de Oliveira Nunes).

Em meio a tantas adversidades, a educação escolar não era uma exceção à regra e buscava uma maneira de se fazer presente. A professora Oliveira, M. A. V. (2018), que foi professora na zona urbana, rural e atuou também como professora formadora de outros professores, contou-nos que em 1976, quando chegou ao município, havia o que poderíamos chamar de um esboço de escola.

Vim do Paraná para Colorado do Oeste em 1976, na
época tinha apenas uma 'escolinha' de pau-a-pique, onde
a primeira professorinha dava aula ali, era uma igrejinha
na qual funcionava também a escolinha. Só que náo era
escola propriamente, a professora mesmo juntou uns
alunos, porque não tinha coordenação, não tinha nada.
(OLIVEIRA, Maria Aparecida Vieira. Colorado do Oeste
- RO, 25 de junho 2018. Entrevista concedida à Marcia
Jovani de Oliveira Nunes).

Lima (1993) conta que devido as delongas do governo em atender as necessidades educativas da regiáo, era comum a própria comunidade instalar ou construir um espaço destinado para o ensino escolar e eleger entre seus membros alguém que demonstrasse aptidão para estar à frente da docência. Como o governo não dispunha de mão de obra qualificada para ocupar tais 
cargos findava por oficializar tanto a escola quanto o professor que nela estava em exercício. A professora Oliveira, I. D. (2018) nos contou como foi sua experiência de tentar criar uma escolinha em meio a floresta, mas ter que abandonar tudo e ir embora porque em dois anos ela e sua família pegaram malária por diversas vezes.

Chegamos ao estado de Rondônia por volta de 1980, moramos no quarto eixo, KM 5. Lá eu quis iniciar uma escolinha, montar uma sala de aula, porque tinham muitas crianças e era longe para eles fazerem 5 quilômetros à pé todos os dias para ir à escola mais próxima que ficava na eixo. Não dava pra deixar as crianças irem sozinhas, os pais da comunidade se ajudavam de forma que cada dia um pai levava as crianças, pois era muito perigoso, existiam cobras, onças, tudo quanto era bicho poderia atacar as crianças, também não tinha estrada, apenas uma picada no meio da mata. Cheguei fazer o levantamento do número de alunos da comunidade que eu morava, fui de casa em casa, perguntado pela idade das crianças, pegando dados verbalmente com as mães, pretendia formar uma turma, construir um casebre e pedir as mínimas condiçôes para lecionar às crianças. Era comum nesta época que os moradores rurais se organizassem e exigissem do secretário da educação municipal essas condiçōes para o ensino, geralmente alguém da comunidade doava ou construía um barraquinho e alguém que soubesse ler e contar virava o professor. Portanto, lá eu comecei juntar essa turma, mas quando estava com vinte e poucos alunos, já pensando no local que iria construir a escola, para que ela ficasse na imediação certa, acessível a todos, começou a malária cada vez mais forte na regiáo, meu marido pegou 14 malárias, eu peguei 13 e minha filha de apenas 2 anos pegou 5 malárias, quase morreu, foi desenganada, então precisamos sair, ir embora. (OLIVEIRA, Ivone Deunízia. Colorado do Oeste - RO, 22 março 2018. Entrevista concedida à Marcia Jovani de Oliveira Nunes).

Para Peres (2015, p.54), mesmo nos dias de hoje, poderia parecer difícil e árduo "ingressar em áreas desprovidas de absolutamente tudo, povoadas por cobras, onças, piranhas, jacarés e nuvens, nuvens, nuvens, nuvens de insetos. Só mesmo imaginando a mais dura necessidade se entende como tantos se lançaram na escuridáo da Amazônia”, contudo, podemos confirmar que a pobreza impulsionava o sonho e dava coragem.

Após curar-se da malária a família sempre regressou à terra, mas certa vez encontrou vizinhos que haviam se apoderado da casa e do pouco que nela 
tinha, além de queimar a lavoura de arroz que haviam plantado; o vizinho com a mão em um arma na cintura aponta para um rádio que era da professora, e que agora estava em sua casa e diz: "o rádio é seu, vai pegá-lo". Com medo da sorte a família abandonou de vez a propriedade. Peres (2015, p.32) afirmou que "onde falta o estado, sobra "justiça" feita com as próprias mãos. Onde faltam perspectivas, abundam desesperança e mão de obra disposta a matar por pouco". Para o autor Rondônia "é a demonstração de como o Estado pode incentivar que miséria e cobiça se encontrem em situaçôes peculiares que só podem desembocar em tragédia”.

\section{"Não vim para ser professora!"}

Nos locais onde a comunidade conseguiu criar a escola, o governo efetivou os primeiros contratos da educação por meio do INCRA; como consequência dessas açóes, que buscaram apenas por panos quentes e atenuar os problemas educacionais, podemos citar: uma multiplicaçáo no quantitativo de escolas que funcionavam em locais impróprios e inadequados; e também um aumento no número de docentes leigo que passaram a equivaler " $33 \%$ do corpo docente geral” (LIMA, 1993, p. 25). A professora Stefannes (2018) compartilhou conosco sua experiência de ingresso no magistério, foi possível perceber que várias das professoras entrevistadas relatam que inicialmente se negaram a assumir a função dizendo que não vieram para Rondônia para serem professoras e utilizaram a expressão de que foram "pegas a laço" para dar aulas.

Cheguei na região do município de Colorado do Oeste - RO em 1976, tinha apenas $5^{a}$ série (ginásio), estudei em colégio de irmã e fui convidada de surpresa para lecionar, insistiram muito, acho que foi o pessoal do INCRA, diziam que precisavam muito que eu assumisse a função de professora, senti receio, achava que não estava preparada para dar aulas [...]. Nós éramos leigos, professores leigos! Nos chamavam de professores leigos, nós sabíamos que éramos professores leigos, a gente não podia assumir uma coisa que a gente não era. [...] O INCRA me ofereceu um contrato federal, para me convencer a dar aula, porque eu estava com muita dúvida, eles diziam: "Você pode assinar um contrato federal, você sabe o que é um contrato federal?" Ai Jesus! Aceitei, mas disse que se percebesse que não daria conta queria ser servente ou outra coisa, náo vim para Rondônia para ser professora. (STEFANNES, Lurdes Panisson. Colorado do Oeste - RO, 10 de junho 2018. Entrevista concedida a Marcia Jovani de Oliveira Nunes) 
Em 1977, o INCRA promoveu uma primeira reunião em Colorado do Oeste para tratar da Educação. Para essa reuniáo foram convidadas verbalmente algumas pessoas que conheciam e sabiam que tinham algum grau de escolaridade. A reunião aconteceu no local onde estava sendo construída a igreja matriz católica da cidade. A professora Oliveira, M. A. V. (2018) decidiu apenas acompanhar uma conhecida que estava hospedada em sua casa e foi participar da reuniáo, mas não tinha pretensóes de se tornar professora, embora já tivesse terminado o ginásio e iniciado o magistério no Paraná. Ela destacou que o critério de seleçáo para escolha do curso não estava relacionado à vocaçáo de ser professora, mas ao desejo de continuar estudando. Como o único curso diurno era magistério e seu pai não a deixava estudar no período noturno, acabou tendo que se conformar com o magistério.

A partir de 1977 o governo, por meio do INCRA, iniciou a escola em Colorado, na época veio a primeira coordenadora de educação de Vilhena, fez a primeira reunião, ao mesmo tempo também estava começando a construçáo da primeira igrejinha católica daqui, as primeiras reuniōes, os primeiros planejamentos, foram feitos ali, os carpinteiros trabalhando, batendo madeira para construçáo da igreja e a gente fazendo o planejamento ali. Eu tinha apenas 16 anos quando vim, tinha o ginásio completo e começado a um semestre o magistério, fiz magistério naquela época porque era um curso durante o dia e o científico era a noite, meu pai não deixava estudar a noite. Então minha família veio embora. Nessa reunião, fui apenas para acompanhar uma conhecida, não tinha intenção nenhuma na minha vida de ser professora, tinha meia dúzia de candidatas, a maioria convidada pelo INCRA. O nome e o grau de escolaridade de todas foi anotado em um caderninho. Só uma colega tinha o magistério, quando a professora que conduzia a reunião apontou para mim eu disse: não eu não vim aqui pra ser professora! A amiga que estava comigo disse: Menina você tem ginásio, olha o pessoal que está aí como que está a situação deles. A professora levou nossos nomes, depois de uma semana marcou para começar, entâo iniciaram as orientaçóes para fazermos o planejamento, ninguém era professor, ninguém tinha experiência, começamos fazer o planejamento. O INCRA anunciou as matrículas para o pessoal, começou a aparecer os alunos, muita gente, porque tinha muita criança. (OLIVEIRA. Maria Aparecida Vieira. Colorado do Oeste - RO, 25 de junho 2018. Entrevista concedida à Marcia Jovani de Oliveira Nunes).

Se nas escolas da cidade as dificuldades eram grandes, os desafios impostos aos colonos coloradenses era ainda maior. A professora Oliveira. M. A. V. (2018) 
relatou que não havia critério para contratação de professores na época, que o INCRA havia construído muitas escolas na zona rural e que o fato da pessoa chegar na comunidade e se estabelecer em um lote rural, se possuísse alguma aptidão ou conhecimento de leitura e escrita tornava-se professor, frente a tamanha carência e necessidade de estabelecer escolas para fixar essas comunidades nos locais onde estavam chegando.

O INCRA construiu escolas de quatro em quatro quilômetros na zona rural, conforme a pessoa chegava e recebia o lote ali perto, se soubesse ler e escrever era professor, não importava o grau de escolaridade, desde que soubesse assinar o nome, ler e fazer alguma coisa foi sendo professor da zona rural. (OLIVEIRA. Maria Aparecida Vieira. Colorado do Oeste - RO, 25 de junho 2018. Entrevista concedida à Marcia Jovani de Oliveira Nunes).

Cada vez mais migrantes chegavam ao sul de Rondônia e mais profundamente na mata adentravam para assentar suas famílias, o sonho da terra abre espaço à decepção, ao chegar percebiam que nada era como prometido e sonhado, o anúncio era de terra, estrada, saúde, escola e igreja, encontravam apenas o lote em floresta, para adentrar tinha fazer picada à facão.

Lima (1993) descreveu que o II Plano Territorial de Educação elaborado para o quadriênio 1981/85 criou um plano de açáo a partir de um diagnóstico que mostrava a situação muito caótica da educação no Estado de Rondônia. Dentre os principais problemas estavam o número alto de crianças fora da escola e o déficit de escolas e servidores; como medida corretiva o governo buscou expandir a rede escolar e contratar professores para a zona rural e urbana, além de administradores escolares, supervisores, bibliotecários, zeladores e merendeiras. Assim, a professora Oliveira, I. D. (2018), que havia abandonado o primeiro lote rural devido a doença da malária e a tomada de suas posses pelos vizinhos, foi morar em outra comunidade rural, próxima de seus pais e familiares. Contou que em Santa Catarina, onde morava antes de vir para Rondônia, era catequista, portanto quando chegou na nova comunidade e tinha uma igrejinha começou a exercer atividades religiosas. Logo perceberam que ela sabia ler, escrever e que tinha desenvoltura no grupo. Como a professora que lecionava na época queria mudar-se para a cidade, precisavam encontrar uma nova professora para substituí-la, então a convidaram para realizar uma prova de seleçáo para o cargo. 
Em 1981, depois de uns 6 meses que eu morava naquela comunidade da zona rural, o presidente da comunidade me procurou pedindo que eu lecionasse na escolinha rural Beija Flor. Ele disse que tinha uma das filhas que estava se candidatando a vaga de professora também. A professora que estava lecionando na época queria se mudar para a cidade, veio falar comigo também, afirmava que eu iria conseguir a vaga porque a outra menina a comunidade não queria porque ela era fraca para dar aulas. Eu sentia receio e dizia que não tinha condições de assumir porque só tinha estudado até a $4^{\mathrm{a}}$ série, mas ela me encorajava dizendo que eu sabia ler nos cultos da igrejinha da comunidade, era catequista, bem desenvolvida, conversava bem, e que iria conseguir. Então vim para a cidade fazer o teste junto com outra candidata. Nos apresentamos ao secretário municipal de educação, ele pegou duas folhas de supetão na gaveta da escrivaninha e disse que eram nossas provas, entramos em uma sala e fizemos o teste. Lembro que errei a silabação tônica na prova, o restante era separação de sílabas, plural, interpretação de texto. Em matemática foi avaliado as quatro operaçóes. Tirei nota 78 e a outra candidata tirou 56, entáo virei professora e fui dar aula [...]. Eu não tinha formação didática, creio que era intuitiva na maioria das vezes, me baseava no que vi meus professores aplicar comigo. (OLIVEIRA, Ivone Deunízia. Colorado do Oeste - RO, 22 março 2018. Entrevista concedida à Marcia Jovani de Oliveira Nunes).

Neste diálogo podemos perceber que a professora relata a existência de um concurso para ingresso em 1981, fato este inédito neste levantamento, pois os ingressos anteriores a esta data contam terem apenas sido convidados pelo INCRA para lecionar, sem critérios de seleção, bastava dar os nomes e iniciar os trabalhos. Neste caso, existiram duas candidatas que realizaram um teste seletivo que continha questóes das disciplinas de língua portuguesa e matemática. Também é possível perceber que a comunidade exercia influência sobre a contratação e permanência dos professores na escola rural e que mesmo não tendo formação didática a professora esforçava-se muito para realizar suas atividades, trabalhava por intuição e baseava-se nas suas experiências como aluna. Pimenta (1999) e Cunha (1997) afirmam que identidade docente se constrói a partir de diversos saberes e referenciais; e que o saber da experiência baseado na observaçáo dos professores que o docente teve em sua trajetória escolar auxiliam nessa construção. Barros (2013, p. 27) acrescenta que "o mestre ou professor era formado na arte do fazer, do praticar". 
A professora Missiatto, M. L. (2018) tinha chegado à cidade de Colorado em 1978, mas como estava com filhos pequenos somente em 1981 decidiu procurar por emprego. Apresentou-se à secretaria municipal de educaçáo a fim de trabalhar como zeladora, embora já tivesse uma breve experiência como professora no Paraná.

Eu tinha estudado até a 7a série no Paraná. Em 1981 fui pedir emprego de zeladora na SEMEC, fiz uma prova junto com outras candidatas, tinha questôes de matemática que envolviam as quatro operaçôes e também redação e interpretação de texto, eu fui muito bem nesse texto, tirei uma nota muito boa, ai a professora me chamou e disse: Missiatto a sua nota foi muito boa, você já foi professora algum dia? Falei que já no Paraná, então você vai ser professora. (MISSIATTO, Maria Lúcia. Colorado do Oeste - RO, 08 de maio 2018. Entrevista concedida à Marcia Jovani de Oliveira Nunes).

A professora Missiatto, M. L. (2018) descreve que fez um concurso para ingressar no serviço público, no entanto, fez a prova com a intenção de ser zeladora, náo professora e que seu resultado influenciou na proposta do cargo, ou seja, não era um teste específico para docência, os conteúdos abordados eram relacionados a matemática e a língua portuguesa, compreendendo redação e interpretação de texto.

\section{"Eu não pensei que poderia viver da educação"}

Embora algumas das entrevistadas tenham afirmado sentir vocação para ser professora e outra ter iniciado o curso do magistério ou vivido breve experiência como professora no sul do país, nenhuma afirmou pensar a docência como uma profissão na qual pudesse receber pela prestação de serviço à comunidade e viver desse trabalho.

$\mathrm{Na}$ época juro que eu não pensava em ganhar dinheiro, eu queria apenas satisfazer aquela minha vocação de dar aula, lidar com aluno, não pensei em dinheiro, eu náo pensei que poderia viver da educação de jeito nenhum. Tanto que o primeiro salário que ganhei, fiquei me perguntando, porque será que eles me pagaram tudo isso? Em relação a hoje era muito dinheiro, lembro que vim para a cidade e fiz compras, fogão, copa e outras coisas pra dentro de casa. Teve uma época que o contrato mudou de municipal para federal, nisso aumentou ainda mais o salário que já era alto. Só que primeiro eu fui professora municipal 8 horas, 
depois meu contrato passou a professora estadual 4 horas e professora federal 4 horas, e acabou que o contrato federal puxou o estadual. (OLIVEIRA, Ivone Deunízia. Colorado do Oeste - RO, 22 março 2018. Entrevista concedida à Marcia Jovani de Oliveira Nunes, grifo nosso).

No final dos anos 70 do século XX alguns estados ainda eram Territórios Federais. Tanto a Constituição brasileira quanto Lei n. 5.692/71, destacavam que a educação nos Territórios Federais era de responsabilidade do Governo Federal. (BRASIL, 1974). A professora Oliveira, M. A. V. (2018) confirma que "o contrato era federal, porque era do antigo Território Federal de Rondônia, nós somos do ex território, e os territórios eram bancados pelo governo federal". A professora Missiatto. M. L. (2018) acrescenta "Salário, eu penso que no começo era mais que hoje, dava pra comprar muita coisa, hoje as coisas são mais difíceis. Era muito, era muita coisa, ou parecia muito”. A professora Fantin, G. (2018) garante que "na época a gente não pensava em salário, ninguém questionava o que ganhava. Meu primeiro salário era assustador, era muito, podia comprar muitas coisas, mas as coisas não eram tão caras como são hoje."

Os excertos das entrevistas evidenciam que todas sentiram-se surpresas diante do valor do primeiro salário, na ocasião não compreendiam porque ganhavam tanto e afirmaram que o poder de compra era muito grande se comparado aos dias de hoje, para boa parte delas, tornar-se profissional da educação foi um divisor de águas em suas vidas, pois garantiu melhores qualidade de vida tanto para elas como para a família.

\section{"Tudo era com o incra nessa época"}

Oliveira (2004) destaca que o INCRA foi criado em 1970 pelo Governo Federal com vistas a expandir a fronteira econômica e a colonização de áreas ainda não ocupadas, como era o caso do Território Federal de Rondônia. Este órgão era responsável por projetos oficiais de colonização e assentamento; mas também tinha como premissa desenvolver açóes para receber, fixar e dar assistência aos migrantes que chegavam continuamente ao estado principalmente após a abertura da BR 364.

Tudo na época era subordinado e coordenado pelo INCRA, não havia outro órgão que não o INCRA, educação, saúde, tudo era com o INCRA nessa época, tinha o projeto de colonização PIC-PAR, entáo tudo era via INCRA, escola, educação, saúde, transporte, tudo que dependesse e 
precisasse era com o INCRA que se resolvia. (OLIVEIRA. Maria Aparecida Vieira. Colorado do Oeste - RO, 25 de junho 2018. Entrevista concedida à Marcia Jovani de Oliveira Nunes).

Gomes (2013) destaca que o INCRA atuava com "presteza e agilidade", era um instrumento do governo utilizado para resolver os problemas da colonização. Dentre os vários projetos de colonização sob a responsabilidade do INCRA estava o PIC-PAR que foi criado em Colorado do Oeste em 1973 e foi o maior motivador de migração para esta região. A professora Stefannes, L.P. (2018) nos conta que "em 1976 quando o INCRA me chamou para ser professora, não haviam as escolas que temos hoje, o ensino acontecia nas casas do INCRA.” Lima (1993) confirma que o INCRA era responsável por prestar assistência aos colonos nas diversas áreas que são de responsabilidade do estado, tais como a educação. Portanto, dentro do INCRA, havia inicialmente um departamento de ensino responsável por instalar e manter escolas.

\section{Relatos das professoras pioneiras na educação}

As narrativas, fruto das entrevistas com as professoras pioneiras na educação do município de Colorado do Oeste - RO permitiram perceber que mesmo tendo decorrido quase meio século daquela época essas personagens contam a história viva, uma história muitas vezes diferente das lidas nos livros. Elas afirmam e contestam muitas informaçóes que são nos apresentadas como verdades absolutas pelas letras imortalizadas nos documentos. Bosi apud Cunha (1997, p.4) afirma que "o passado não é o antecedente do presente, é sua fonte", portanto, construímos as narrativas na perspectiva, não apenas de descrever a realidade, mas principalmente produzir novos conhecimentos que possam justificar e permitir novas interpretaçóes do presente.

Observamos a partir dos relatos das professoras e dos referencias teóricos que embasaram esta pesquisa que o Território Federal de Rondônia aumentou seu número de habitantes em praticamente 353\% no final dos anos de 1970 e início dos anos de 1980. É possível perceber que o processo migratório para Rondônia trouxe pessoas das diversas regióes brasileiras, Oliveira (2004) afirma que grande parte da imigração desta década era originária especialmente dos estados do Paraná, Minas Gerais, Espírito Santo e da Região Nordeste. As entrevistas realizadas com as professoras pioneiras das escolas coloradenses confirmam este dado, pois todas as entrevistadas eram da região sul do país, a maioria do estado do Paraná e uma catarinense. 
Peres (2015) explica o fato da predominância sulista afirmando que naquela época o sul do Brasil vivenciava a chamada "Revolução Verde" e os estados se transformaram em laboratórios de tecnologia agrária, grandes empresas praticamente expulsaram os pequenos agricultores de suas propriedades; os colonos, sem ter como concorrer com a mecanizaçáo e os agrotóxicos, migraram para o norte.

O autor afirma que existe pouca historiografia sobre Rondônia, "os livros são poucos, a maioria se retroalimenta, alguns são oficialistas demais para que neles se acredite" (PERES, 2015, p. 23) e que os documentos tido como oficiais são frios e não podem ser tomados como única verdade, destaca e valoriza a importância da utilização das entrevistas para contar uma nova história, afirma que "a versão que existe sempre vai prevalecer sobre aquela que inexiste. No vazio crescem a mentira, o boato, a suposição” (PERES, 2015, p. 21) e que "nada é mais nocivo a construção de versóes honestas que a omissão e a ocultação". (PERES, 2015, p. 20); vê no estudo da história regional e local uma possibilidade para aprendizagem e não repetição de erros, "as falhas, os crimes, as omissóes se renovam, entram novas formas de ser, e apenas a análise das causas é capaz de evitar consequências negativas" (PERES, 2015, PP. 22- 23). Assim, após observar este contexto foi possível notar que apesar do discurso governamental apresentar a intenção de povoar e defender a fronteira brasileira, nota-se que houve um total despreparo no sentido de atender ao alto fluxo migratório que chegava ao Território Federal de Rondônia. A população migrante enfrentava diversas tribulaçóes e desafios relacionados tanto a infraestrutura inadequada quanto a assistência pública. $\mathrm{O}$ Estado passou a ser representado pela figura do INCRA no município, e este assumiu poder arbitrário sobre as diversas situações apresentadas.

Em 1970 as tensóes sociais eram muito grandes, havia muita pobreza causada pelo aumento do número de pessoas nas cidades, a seca do nordeste assustava e apontava para a miséria; e repressão, causadas principalmente a partir do golpe militar contra João Goulart; "a ditadura apostava na facilitaçáo dos lucros privados mediante a concessão de bondades e a garantia de mão de obra farta e barata”. Na regiáo sul e nordeste iniciaram-se os movimentos pela terra, o que parecia óbvio foi oferecido pelo ditador Emílio Garrastazu Médice, "uma terra sem homens para homens sem terra", impondo uma ideia, que soou como sonho e esperança para o pobre, de que "a Amazônia era o destino perfeito para aqueles milhares de pessoas” (PERES, 2015, p. 36).

O processo precisava ser acelerado porque o êxodo rural estava superlotando as principais capitais, os pobre nordestino queriam ir para o sudeste 
"ganhar a vida" na cidade grande, no sul boa parte dos colonos, que já estavam sem terra, começam a organizar movimentos de reivindicação de reforma agrária. A estratégia militar era mandar todo esse "problema" para o norte, assim, "o regime esperava varrer para debaixo do tapete amazônico, longe das vistas sensíveis à pobreza” (PERES, 2015, p. 39). A ilusão e o sonho começou a ser vendido para o povo pobre, miserável e sem terra, uma chance de possuir a sonhada terra. O governo militar daria todo suporte, auxílio aos migrantes, salário até que se fixassem na terra.

Por diversas vezes, nos anos que antecederam esta história, houve tentativa frustradas de domesticar a selva amazônica que se impunha e resistia naturalmente, no entanto, desta vez poderia ser diferente, "os militares estavam dispostos a mudar o jogo" e "provar que a força do homem prevalecia sobre a da natureza", para tanto, utilizaram-se do poder do estado para financiar e intervir neste processo, que náo tinha como principal objetivo resolver o problema da pobreza, miséria e falta de terra, mas, estar "a serviço da acumulaçáo de extraordinários capitais por uns poucos grupos, nacionais e estrangeiros" (PERES, 2015, p. 37).

Apesar da região amazônica ser inexplorada, os militares conheciam muito bem os dados referentes a sua fertilidade da terra, pois o Ministério da Agricultura produziu um mapa em 1979 que evidenciava as características de cada hectare de Rondônia e as possibilidades de atividades exploratórias com potencial madeireiro e agrícola que permitiam a mecanização. "[...] as áreas mais férteis estão do centro para o sul do estado, [...] a legenda diz "aptidão boa nos níveis A,B e C. O quadro ao lado traduz: perfeito para qualquer cultivo, ótimo para mecanização" (PERES, 2015, p. 51). "No entanto, quando os militares colocaram em prática a política de dupla distribuição entre corporaçóes e latifundiários, de um lado, e sem-terra, do outro. Não é preciso perder tempo explicando para quem foram os melhores nacos de área pública” (PERES, 2015, p. 24).

As professoras que atuaram na zona rural contaram que os pais de seus alunos, sempre pequenos agricultores, depois de desmatar, plantar e colher, não tinham dinheiro para realizar o manejo adequado da terra, o segundo ciclo de plantação trazia consigo doenças e pragas que o cultivo na terra virgem não traz, então por necessidade e incentivados a desmatar, pela política do estado, reiniciavam o processo de desmatar, plantar e colher, até que a terra ficasse totalmente nua, não tendo como cuidá-la, deixavam o pasto crescer, mas não tinham dinheiro para colocar gado, então vendiam, e assim foram formando-se os grandes latifúndios pecuários, incorporando-se uma a uma as pequenas propriedades. Os militares 
cumpriram com a promessa de mão de obra farta e barata, pois desmatar e destocar é um trabalho que não custará mais ao novo proprietário.

O INCRA foi muito importante para o sucesso dessa operação, para alguns, principalmente os pobres, ele era a tábua de salvação, o único recurso, o provedor, quem tudo sabia e decidia, alguns historiadores e entrevistadas também elogiaram o órgão pela prestação de serviços da época, no entanto para outros ele era um inimigo infiltrado, Peres (2015, p. 54) descreve que "o INCRA era lento demais, suspeito demais para atender as urgentes necessidades" do povo.

Quando em 1972 o INCRA colocou em concorrência pública 500 mil hectares de terra em Rondônia "o tamanho dos lotes, dois mil a três mil hectares, e a exigência de um detalhado anteprojeto com cultivo, técnicas empregadas e potencial de criação de postos de trabalho não deixam dúvidas de que a intenção não era destinar estas áreas aos pobres”. Peres (2015) destaca que as regiôes e talhóes de terras mais propícios à produção foram servidos como "filés do banquete agronômico" (PERES, 2015, p. 51), desta forma "a ditadura transformou fazendeiros medianos, médicos, engenheiros e economistas em latifundiários, que contavam não apenas com a terra, mas com isençóes fiscais e tributárias fenomenais" (PERES, 2015, p. 57).

A escassez de mão de obra qualificada para exercer as atividades públicas nos diversos setores principalmente saúde, educação e segurança, faz com que o INCRA promova açóes que na maioria das vezes apenas maquiavam as situaçóes e problemas apresentados pela população. Os improvisos principalmente na área da educação não resolviam, mas funcionavam como uma "cala a boca", pois mesmo não havendo professores habilitados e escolas com infraestrutura adequada, a população, principalmente a rural, tinha a cada $4 \mathrm{~km}$ uma escola com professora, o que neste contexto era apresentado como a única coisa possível de se fazer.

As açóes emergenciais desenvolvidas pelo INCRA no âmbito da educação, voltadas a contratação de professores leigos, não estavam de acordo com as determinaçóes da LDB 5.692/71 que exigia a formação mínima para o exercício do magistério, portanto o governo precisou desenvolver novas estratégias, também emergenciais, para capacitar os professores leigos. Lima (1993, p.21) destacou que o governo buscou solucionar os problemas da educação oferecendo o projeto Logos II "um programa de capacitaçáo e habilitação de docentes [leigos] e de construção de prédios escolares".

É possível perceber que o tema Educação ligava-se diretamente ao discurso de desenvolvimento econômico da regiáo, portanto, era utilizado como uma 
estratégia governamental para maquiar, mascarar e esconder problemas de outra natureza e complexidade, como questóes econômicas, políticas e sociais próprias da abertura do novo Estado. Assim, o governo precisava da figura do professor para efetivar seu projeto político social de organização do novo Estado fixando os migrantes na regiáo.

\section{Considerações finais}

O recrutamento, seleção e contratação dos profissionais da educação coloradense se dava por meio de nomeaçóes e designaçóes que estavam inicialmente sobre a responsabilidade do INCRA, estas nomeaçóes posteriormente tornaram-se efetivas. Não haviam critérios sobre a formaçáo escolar mínima exigida para o cargo de professor, somente a partir de a constituição do Estado de Rondônia de 1981 iniciaram-se as cobranças para o cumprimento da LDB 5.692/71 e, portanto, o surgimento do apressado projeto de formaçáo Logos II.

A figura das escolas do município de Colorado do Oeste, em especial das rurais, na década de 1970 e início de 1980, refletiam locais improvisados e inapropriados, com pouca ou nenhuma infraestrutura física para atendimento tanto do alunado como das professoras. $\mathrm{O}$ sexo feminino representa a maioria do professorado da época. Apesar de as referências bibliográficas apontarem baixo investimento financeiro na remuneração docente, por parte do governo, é possível observar que todas as entrevistadas na pesquisa descrevem entusiasmadas os valores de seus salários, e principalmente o poder de compra que seus honorários representavam. Talvez não seja difícil compreender tal ponto de vista se considerarmos que estamos falando de pessoas que vieram para o estado sem recursos, sem terra e sem perspectivas.

Algumas referências trazem informaçóes que tratam que a assunção da carreira do magistério pelas mulheres ajudava a compor o orçamento familiar, no entanto, na regiáo era praticamente a professora que mantinha as despesas do lar. Existia até mesmo uma piadinha regional aos esposos das professoras que era: "Qual a sua profissão? - Sou marido de professora." Dando a entender que a professora era a "chefe" da casa, responsável pelo principal provimento do lar.

Algumas professoras destacaram a participação dos maridos nas atividades relacionadas às escolas onde trabalhavam, seja para mapear alunos e compor as turmas na escola, seja para buscar, transportar e fazer a merenda escolar. 
Novamente podemos entender que diante da pobreza e das limitaçóes para se trabalhar nas terras, que por sua vez não eram muitas vezes as melhores, era mais vantajoso aos maridos, auxiliar no trabalho da esposa e garantir o sustento com o seu salário.

As professoras pioneiras me contaram tudo o que seus olhos viram acontecer, almejo quiçá um dia conseguir retratar com fidelidade as nuances de suas histórias, para que nos sirvam de inspiração e compreensão para nossas próprias histórias.

\section{Referências}

BARDIN, Laurence. Análise de conteúdo. São Paulo: Edições 70, 2011.

BARROS, Josemir Almeida. Organizaçáo do ensino rural em Minas Gerais, suas muitas faces em fins dos IXX e início do XX (1899-1911). 2013. 349 f. Tese (Doutorado) - Curso de Programa de Pós-Graduação em Educação da Universidade Federal de Uberlândia.

BRASIL. MEC. Departamento de Ensino Supletivo. Projeto Logos I Ensino à distância na qualificaçáo de professores leigos: o desafio, a experimentação, o resultado. Brasília: Departamento de Comunicação e Divulgação, 1974.

CUNHA, Maria Isabel da. Conta-me agora! As narrativas como alternativas pedagógicas na pesquisa e no ensino. Revista da Faculdade de Educaçáo, n. 1-2, Jan./Dez. 1997. Disponível em: http://www.scielo.br/scielo. php?script $=$ sci_arttext $\&$ pid $=$ S0102-25551997000100010. Acesso em: 02 de abril 2018.

GALVÃO, Ana Maria de Oliveira; LOPES, Eliane Maria Teixeira. Território plural: a pesquisa em história da educação. São Paulo: Ática, 2010.

LE GOFF, Jacques. História e memória. Campinas: Sp, 1990.

GOMES, Emmanoel. A abertura da BR-029 atual 364. Rondônia em pauta. 2013.

GRAZZIOTIN, Luciane Scarbi Santos; ALMEIDA, Doris Bittencourt. Romagem do tempo e recantos da memória: Reflexôes metodológicas sobre História Oral. São Leopoldo: Oikos, 2012.

LIMA, Abnael Machado de. Achegas para a história da educaçáo no Estado de Rondônia. 2. ed. Porto Velho: Secretaria de Estado da Educaçáo de Rondônia, 1993. 
LIMA, Abnael Machado de. Prática educativa no Território Federal do Guaporé/Rondônia. Porto Velho: Secretaria de Estado da Educação de Rondônia, 1980.

LUZURIAGA, Lourenzo. História da educaçáo e da pedagogia. 10. ed. Tradução: Luiz Damasco Penna e J. B. Damasco Penna. São Paulo: Cia. Editora Nacional, 1978.

MEIHY, José Carlos Sebe Bom. Manual de história oral. 5. ed. São Paulo: Edições Loyola, 2005.

NOSELLA, Paollo; BUFFA, Ester. Instituiçóes escolares: por que e como pesquisar. Campinas: Alínea, 2009.

OLIVEIRA, Ovídio Amélio. História desenvolvimento e colonização do Estado de Rondônia. 5a ed. Porto Velho: Dinâmica, 2004.

PERES, João. Corumbiara: caso enterrado. São Paulo: Elefante, 2015.

PIMENTA, Selma Garrido. Formação de professores: identidade e saberes da docência. In: PIMENTA, Selma Garrido. (org.). Saberes pedagógicos e atividade docente. Sáo Paulo: Cortez Editora, 1999. (p. 15 a 34)

VIEIRA, Maria do Pilar ; PEIXOTO, Maria do Rosário; KHOURY, Yara Aun. A pesquisa em história. 2. ed. São Paulo: Ática, 1991.

\section{Entrevistas}

FANTIN. G. Depoimento [25 de junho 2018]. Colorado do Oeste - RO. 2018. Entrevista concedida a Marcia Jovani de Oliveira Nunes.

MISSIATTO. M. L. Depoimento [08 de maio 2018]. Colorado do Oeste RO. 2018. Entrevista concedida a Marcia Jovani de Oliveira Nunes.

OLIVEIRA, I. D. Depoimento [22 de março 2018]. Colorado do Oeste RO. 2018. Entrevista concedida a Marcia Jovani de Oliveira Nunes.

OLIVEIRA. M. A. V. Depoimento [25 de junho 2018]. Colorado do Oeste - RO. 2018. Entrevista concedida a Marcia Jovani de Oliveira Nunes.

STEFANNES. L. P. Depoimento [10 de junho 2018]. Colorado do Oeste RO. 2018. Entrevista concedida a Marcia Jovani de Oliveira Nunes. 


\section{CAPÍtulo 4 \\ O ASSOALHO DA ESCOLA AINDA "ECOA": HISTÓRIAS E MEMÓRIAS DE UMA ESCOLA}

Helen Arantes Martins

Alceu Zoia

\section{Introdução: \\ as primeiras palavras de um "lembrar e (re)construir"}

[...] Este livro foi escrito

Por uma mulher que fez a escala da Montanha da vida Removendo pedras E plantando flores.

Este livro:

Versos [...] Não.

Poesia [...] Não.

Um modo diferente de contar velhas estórias.

(Cora Carolina)

As primeiras palavras de abertura dessa pesquisa, as de Cora Carolina proporcionaram-me pensar sobre o que me propus a pesquisar. Náo eram versos, não era poesia, era como tão bem colocou a autora, "um modo diferente de contar velhas estórias" (CORALINA, 1983, p. 3). O meu desejo incontrolável era escutar a voz, de refazer, reconstruir, repensar, reescrever uma história composta por tantos sonhos, lutas, derrotas, vitórias, gentes, mãos. De um modo diferente!

Nas décadas de 1960-1980, a regiáo norte do Brasil foi alvo de uma proporção elevada de migraçáo que chegou a estimativa de cerca "600 mil pessoas" (CUNHA, 2015, p. 01). A migração para a regiáo foi marcada por três grandes fenômenos, sendo o primeiro, a extração da borracha, da cassiterita e do ouro; o segundo, a abertura das estradas para passagem das linhas telegráficas; e o terceiro foi a movimentação migratória, provocada por anúncios e propagandas governamentais de terras férteis e sua distribuição. 
As chamadas publicitárias, organizadas pelo poder capitalista, eram um dos principais responsáveis pela movimentação da migração, causando uma proporçáo acelerada de crescimento dos vilarejos, o que gerava conflitos do tipo: faltas de moradia, estrutura, saúde e escola. As muitas propagandas alimentavam o sonho da terra própria, apontando um caminho para condiçóes melhores de criação dos filhos e até mesmo de subsistência, como é o exemplo do meu próprio avô e pai. Esses serviram de cobaia para as camufladas estratégias governamentais, cujo interesse era povoar a regiáo norte do país para a extração e integração das terras que poderiam ser ocupadas por países vizinhos e também para abastecer com grãos as industrializaçóes e exportaçóes, que movimentavam os cofres públicos.

Desse modo, no que se refere à migração da região norte, grandes foram os fluxos migratórios saindo do Centro Oeste do Paraná para região, acreditando ser possível fazer uma expressiva "Fronteira Agrícola Norte" (BAENINGER; CUNHA, 2008, p. 09). Para a permanência e chamada dos migrantes, o Governo Federal começou a fazer investimentos através de seus órgáos deliberativos. Esses migrantes foram ocupando terras e se aglomerando em pequenos povoados. As ocupaçóes não foram nem cordiais, nem pacíficas e o uso da força foi primordial e os índios que habitavam as regiôes foram aos poucos sendo afastados, mortos ou excluídos de suas ocupaçóes.

Para Cambi (1999, p. 30), deve haver uma conscientização da sociedade atual sobre a história, sobre as negligências e as lutas, pois do contrário, estamos silenciando e direcionando o espaço a uma sociedade homogênea, ignorando as condiçóes histórico-sociais do passado que caracterizaram sua aparência na contemporaneidade. Portanto, reconhecer a história da conflituosa relação cultural é indispensável, é esse o caminho "doador das fontes" e das reflexóes do estado atual de nossa sociedade.

Mesmo que em sucintas palavras podemos ter uma noção da história da migração do povo brasileiro para Rondônia, deparamos com uma gama de questóes e fenômenos marcados por negligência e precariedade que colocaram a população em situação de vulnerabilidade social.

Delimitamos como lócus de nossa pesquisa a cidade de Vilhena, lugar de onde falo, e que fazia parte do então Território Federal de Rondônia. Afunilamos nosso olhar a pensar na necessidade de escolarização que surgiu diante dos percalços sociais de uma região, que não oferecia nenhum tipo de assistência às famílias migrantes que chegavam durante 
o período delineado e que também amargava os problemas enfrentados pela sociedade que se constituía junto à educação, com a falta de garantias mínimas de sobrevivência.

Nessa perspectiva, esta pesquisa buscou investigar a formação educacional escolar de Vilhena/RO, entre o período de 1960-1980, notadamente a implementação da Escola "Wilson Camargo", primeiro estabelecimento de ensino. Optamos por trabalhar com as narrativas de memória de professores e alunos, fundamentada a partir da história oral, a fim de "[...] transformar isso outra vez em experiências dos que ouvem a história.” (FREITAS, 2006, p. 58). Para se trabalhar com a memória exige-se atenção aos procedimentos que envolvem a metodologia. Assim, buscamos apresentar os caminhos e contornos de configuração que a pesquisa tomou, para que pudéssemos transformar todo o percurso em documentos de pesquisa.

Delgado (2010) acredita que o significante da pesquisa é o contato do pesquisador com o fenômeno da pesquisa. Quando o pesquisador se entrega à pesquisa, há uma transformação de identidade que o impulsiona a ser um investigador. O respeito, o valor de cada sujeito social apresentado é uma característica da lição primordial de ética sobre a experiência com o trabalho de campo na história oral.

Para continuidade e desenvolvimento da pesquisa selecionamos uma rede de depoentes, marcamos visitas e horários para gravar as narrativas rememoradas. Todos assinaram o Termo de Consentimento Livre e Esclarecido aceitando e autorizado a participação na pesquisa, em data previstas e agendadas iniciamos os trabalhos.

\section{Recompondo os contos: a primeira escola de Vilhena/RO}

No início da investigação, tudo parecia linear, até o momento que nos deparamos com essa narrativa que instantaneamente mobilizou nossa atenção: era uma história construída desde a minha fase de aluna da escola Wilson Camargo. Dúvidas começaram a saltitar de nossas mentes e novos rumos investigativos foram repensados. Não estávamos preocupados em construir "verdades", o intuito foi conhecer o outro lado da história.

A história da educação de Vilhena está errada. A verdadeira história tem que ser contada da maneira certa, o nome da escola não foi em homenagem a nenhum normalista. 
Esse normalista, acho que nunca existiu! A gente não tinha educação aqui, eu mesma não fui à escola, depois que fizeram uma casinha para ser a escola. ${ }^{1}$ (BASILINA, Vilhena, 20/01/2017).

Isso não quer dizer que a pesquisa seja falha, isso quer dizer que essa pesquisa "[...] privilegia o anônimo e o cotidiano onde zooms destacam detalhes metonímicos - partes tomadas pelo todo." (CERTEAU, 2012, p. 55 grifos do autor). As idas e vindas da escola, as visitas em arquivos, as narraçóes, as prosas. Pareciam nos fazer sentir as palavras de Certeau (2012, p. 43), ao descrever que;

Eu me esquecia do acaso da circunstância, o bom tempo ou a tempestade, o sol ou o frio, o amanhecer ou o anoitecer, o gosto dos morangos ou do abandono, a mensagem, ouvida as meias, a manchete dos jornais, a voz ao telefone, a conversa mais anódina, o homem ou a mulher mais anônimos, tudo aquilo que fala, rumoreja, passa, aflora, vem ao nosso encontro.

Não estávamos preocupados em encontrar os "donos da verdade" na rememoração, reafirmamos a "[...] importância de tomarmos conhecimento dos processos vivos de criação humana dos sujeitos que tecem a trama histórica." (GOLDER, 2004, p. 15). Ou seja, são os sujeitos que falam, que vivem, aqueles que reconstroem e constroem a história.

A educação na cidade de Vilhena começou nas casas dos próprios moradores, aqueles que sabiam ler e escrever ensinavam o próximo da família, como uma herança cultural transmitida de um para o outro: «Eu aprendi os primeiros rabiscos com minha mãe, meu pai mandou buscar uma cartilha lá em Utiariti ${ }^{2}$ que tinha vindo de Cuiabá”. (BASILINA, Vilhena, 20/01/2017). Como vemos no relato de Basilina, as cartilhas serviam como instrumento de ensino e os passos eram seguidos de acordo com as instruçóes que vinham no desenvolvimento das atividades elaboradas pela cartilha. Dona Basilina narra que seguia a fio as orientaçóes do pai e da mãe que pouco sabiam, porém, ensinavam enfrentando juntos as dificuldades.

As famílias de trabalhadores que vinham para o pequeno vilarejo de Vilhena se juntavam aos indígenas e ribeirinhos que já ocupavam os

1 Todos os depoimentos foram selecionados em itálico no corpo do texto.

2 Município situado no Mato Grosso atual cidade de Diamantino. Esse vilarejo servia de apoio para os sujeitos que viviam em lugares isolados. 
espaços para servir de mão de obra para a construção da rodovia e abertura da cidade de Vilhena. A "invenção" 3 da vida cotidiana dessas famílias vai se escalonando com as técnicas do trabalho.

Para a permanência das famílias nas inóspitas terras, Sebastião Camargo, dono e responsável da construtora/colonizadora Camargo Corrêa S/A teve como responsabilidade construir escolas e construiu uma pequena casinha que servia como a escola do vilarejo para atender aos filhos dos trabalhadores da construtora, dos ribeirinhos e dos indígenas que viviam no pequeno vilarejo. Assim, as famílias poderiam se "fixar" na região, já que a empreiteira necessitava da máo de obra dos trabalhadores locais.

Assim, a rústica escola fora construída tendo as características de uma casinha simples de madeira, com uma porta na frente e duas janelas de madeira. O telhado era feito de telhas de vinil, presas com pregos grandes, sem forro ou energia elétrica. O chão batido de terra, as paredes eram de madeira com cores variadas, da beleza natural do recurso, parecia pintar o futuro das crianças que esperavam e sonhavam com o espaço escolar, pois, “[...] o enfoque da cultura começa quando o homem ordinário se torna o narrador, quando define o lugar (comum) do discurso e o espaço (anônimo) de seu desenvolvimento." (CERTEAU, 2012, p. 61). As características da rúsctica escolinha muito se assemelhava as de outras escolas de cidades que nasciam de projetos de colonização do período em estudo abrindo espaço para a cultura escolar.

$\mathrm{Na}$ fotografia 1, logo abaixo, temos a imagem da primeira escola, que com os restos de tabúas que sobravam das madeireiras e ainda com ferpas, eram feitos os bancos, que com o tempo eram alisados pela movimentaçáo e plainada das máos. Alguns dos materiais foram doados pela construtora/ colonizadora Camargo Corrêa S/A, e o restante dos materiais eram recursos da natureza que cercava a região. Podemos ainda perceber a partir da imagem que bem na frente da pequena escola foi colocado uma placa com o primeiro nome da escola sendo, "Escola Rural Wilson Camargo" e, mais abaixo, o nome Pires de Sá, principal rio que cortava a cidade e servia de recurso para as famílias. Ao lado direito estava o suporte para a bandeira do Brasil, como um saudosismo à pátria e também representava um espaço e um sentimento de pertencimento ao país.

3 Termo utilizado por Michel de Certeau (2012) no livro: A invenção do cotidiano: 1. Artes de fazer. A referência da obra se encontra no final dessa pesquisa, para maiores informaçóes. 


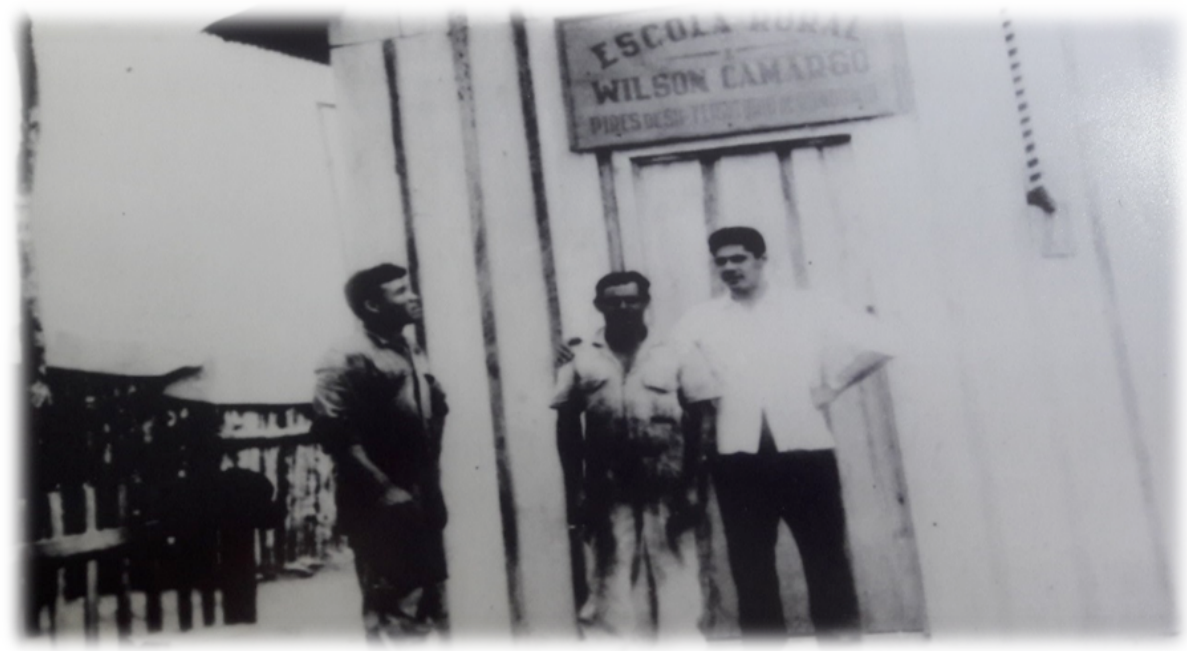

Fonte: Arquivo de memória da escola "Camargo Corrêa S/A".

Alicerçados pelas memórias, vamos cuidadosamente tecendo a história, incorporando todos os minuciosos detalhes da educação de Vilhena. Assim, adentrando no interior da pequena escola, podemos constatar durante as narrativas, que as aulas eram ministradas por aqueles que sabiam pelo menos o mínimo da leitura e escrita. Os conteúdos das aulas estavam contidos nas cartilhas que o senhor Sebastiáo Camargo mandava buscar no vilarejo de Utiariti, ponto de apoio para as mercadorias vindas de Cuiabá/MT.

Cada família era responsável por providenciar o caderno, o lápis e a borracha. As aulas aconteciam somente na parte da manhá, até por volta das $11 \mathrm{~h}$. Os ensinamos eram pautados na memorização das letras e na reprodução da escrita.

Dona Basilina realça em suas memórias o desejo de frequentar uma sala de aula, pois da janela avançavam os olhares desejos de ocupar um lugar no banco escolar e aprender nas aulas ministradas pela professora Esmeralda: "Tudo era muito simples e sem luxo! Tinha vez que eu ia levar meus irmáos e ficava na janela, olhando a Dona Esmeralda esposa de Osmar Costa dar aula.”. (BASILINA, Vilhena, 20/01/2017).

A imagem da foto nos possibilitou diversas leituras para o período histórico da década de 1960. A imagem ainda retrata o dia da inauguração da primeira escola do vilarejo, as pessoas da imagem era o senhor Sebastiáo 
Camargo à direita, um trabalhador da empreitera ao meio e o indígena Marciano Zonoecê.

A escola, no início, era rural. Cabe, pensar aqui que até meados de 1960, grande parte da populaçáo brasileira vivia em espaços rurais. Com o golpe de 1930, a sociedade que antes era agrária passou a ser uma sociedade urbana industrial. Porém, mesmo com a transformação das cidades, o campo continuou a ter sua relevância, uma vez que abastecia as cidades. As forças políticas da burguesia incentivavam com estratégias governamentais, a migração para os centros urbanos, fazendo os pequenos produtores vulneráveis aos grandes latifúndios, ou seja, "com a crise provocada pela queda do preço do café, muitos trabalhadores do campo, das fazendas de café, foram obrigados a buscar trabalho nas cidades, ou seja, transformaram-se em operários, mão de obra para a indústria” (PERIPOLLI, 2009, p. 58).

Faz-se necessário enfatizar, de acordo com Perdigão e Bassegio (1992), que ainda em meados de 1980 a região norte estava em processo de (re) ocupação, cerca de $65 \%$ da população vivia no meio rural. Diversas famílias eram incentivadas a se deslocar em busca predominantemente de terras rurais, que posteriormente se tornarim os espaços urbanos. "O que o sistema quer com as famílias de migrantes é que elas preparem o terreno para as futuras empresas agropecuárias." (PERDIGÃO; BASSEGIO, 1992, p. 172).

Contempla ainda descrever que para os autores existem basicamente três maneiras de ocupar uma região de fronteira agrícola. Uma delas é a implantação de grandes fazendas em plena selva, o regime de escravidão e o processo da colonizaçáo. De acordo com os autores, esses aspectos estiveram presentes na regiáo Norte.

Naturalmente, em Rondônia, optou-se pela estratégia da colonização porque esta propicia não só a criação de bolsóes de subsistência de mão-de-obra na região, como também o barateamento do custo da mesma. Fica evidente que o modelo físico de ocupaçáo proposto para o Território de Rondônia constitui-se num magnífico exemplo de tentativa oficial de formar núcleos de pequenos produtores destinados a se autoproduzirem como forças de trabalho para a empresa agropecuária. Inicialmente o governo faz pequenos investimentos para garantir essa mão-de-obra, como: estradas, escolas etc. Mas seu objetivo último é garantir a mão-de-obra para o capitalismo que se implantará. Este o objetivo último de 
se deslocar tantas famílias de migrantes para Rondônia. (PERDIGÃO; BASSEGIO, 1992, p. 172).

A ocupação da Regiáo Norte vem acompanhada com diversas estratégias para manter os colonos na regiáo. Os incentivos fiscais também foram argumentos que reforçaram a atrair investidores privados. As políticas educacionais ficaram à mercê da conquista e luta da comunidade para que ocorra sua efetivação. Para Certeau (2012, p. 86), toda essa relação se aparenta a um jogo de maneiras. "[...] por essa combinação, cria para si um espaço de jogo para maneiras de utilizar a ordem imposta do lugar ou da língua. Sem sair do lugar onde tem que viver e que lhe impóe uma lei, ele aí instaura pluralidade e criatividade.”.

A responsabilidade atravessa toda comunidade que luta e reivindica melhorias. Nesse movimento de migração chega ao pequeno vilarejo uma professora com formação em magistério com o nome de Professora Noeme Barros Pereira. Devido a sua formação, começou a desempenhar trabalhos educacionais, coordenar as atividades da rústica escola e preparar as aulas para as crianças. Com o crescimento da sociedade, comércios foram surgindo, porém, o acesso à região ainda era muito difícil e essas dificuldades influenciavam no custo dos recursos e outros. Os materiais escolares também estavam inseridos nesses produtos de alto custo, os pais eram os responsáveis em comprar os materiais escolares para que os filhos estudassem e a professora pudesse dar continuidade às aulas.

No decorrer das aulas, as atividades escolares eram fortalecidas com a ajuda de um professor normalista ${ }^{4}$, esses juntam se à sociedade para fazer reivindicaçóes e pedir um espaço adequado e uma escola que atendesse de forma segura as crianças, pois a primeira escola já apresentava perigo. Nos dias de chuva forte a pequena casinha, com estruturas um tanto abaladas por conta do tempo, tinha que ser esvaziada.

A missão da escola era o atendimento daquela população que aumentava gradativamente, o espaço que antes era um tanto rude e localizado em espaço rural passa a ter abertura de estradas e formas de uma cidade.

4 A história do nome da escola "Escola Isolada Wilson Camargo" até a década de 1990 estava envolvida a um conhecimento empírico de que fora em homenagem ao professor normalista Wilson Coutinho. Esse professor chegou a atuar na educação das crianças de Vilhena. No ano de 2010 a escola comemorou 50 anos de existência e o filho do dono da empreiteira Camargo Corrêa S/A, foi pessoalmente à escola explicar a caracterização do nome e pedir para que a história da escola fosse revisitada, ou seja, ela existe muito antes do decreto de lei no353 de 10 de agosto de 1960 que caracteriza a abertura da escola. A origem do nome é uma homenagem ao pai Sebastiáo Corrêa e a construtora colonizadora Camargo Corrêa S/A (Relato da atual gestora da escola Professora TATI, 2015). 
No ano de 1960, as lutas e as reivindicaçóes alcançam o Departamento de Educação do Território Federal de Rondônia e as solicitaçóes surgem efeito. A gestão de Paulo Nunes Leal fixa o Decreto no353 de criação da escola no dia 10 de agosto de 1960. Para Mészáros (2008), com o tempo;

[...] as classes dominantes já não podem governar à maneira antiga, e as classes subalternas já não querem viver à maneira antiga. Esses são momentos absolutamente extraordinários na história, como o demonstraram no passado [...]. Portanto, seja em relação à "manutenção", seja em relação à "mudança" de uma dada concepçâo do mundo, a questão fundamental é a necessidade de modificar, de uma forma duradoura, o modo de internalização [...]. (MÉSZÁROS, 2008, p. 51).

A crítica de Mészáros(2008) a classe dominante ressalta a negligência de atendimentos que pairava na educação e destaca também que precisamos superar a maneira antiga de governar aplicando e disponibilizando o que é de direito da população.

Na figura 1, logo em seguida, temos o documento de decreto instituindo a criação da escola e expressando que por obter um quantitativo expressivo de pessoas na sociedade, e que o crescimento demográfico da região é levado em consideração, pois o crescimento se deve após a abertura da BR-029, reforçando e reconhecendo ainda mais a relaçáo da migração com a educação e a necessidade de atendimento às crianças e adolescentes.

No decorrer dos artigos de número $1^{\circ}$ e $2^{\circ}$ do decreto, menciona-se que será construído um prédio especialmente para o atendimento desses alunos e por se tratar de uma escola Isolada ${ }^{5}$, sua denominaçáo oficial foi Escola Isolada Wilson Camargo. Isso pode ser confirmado com o decreto de criação da escola:

5 Vilhena é um dos municípios mais distante de Porto Velho com $720 \mathrm{~km}$. (atual capital do Estado), os municípios vizinhos foram colonizados depois de Vilhena que servia como ponto de apoio aos demais. Então a escola seria "Isolada" por ser a única na região. 


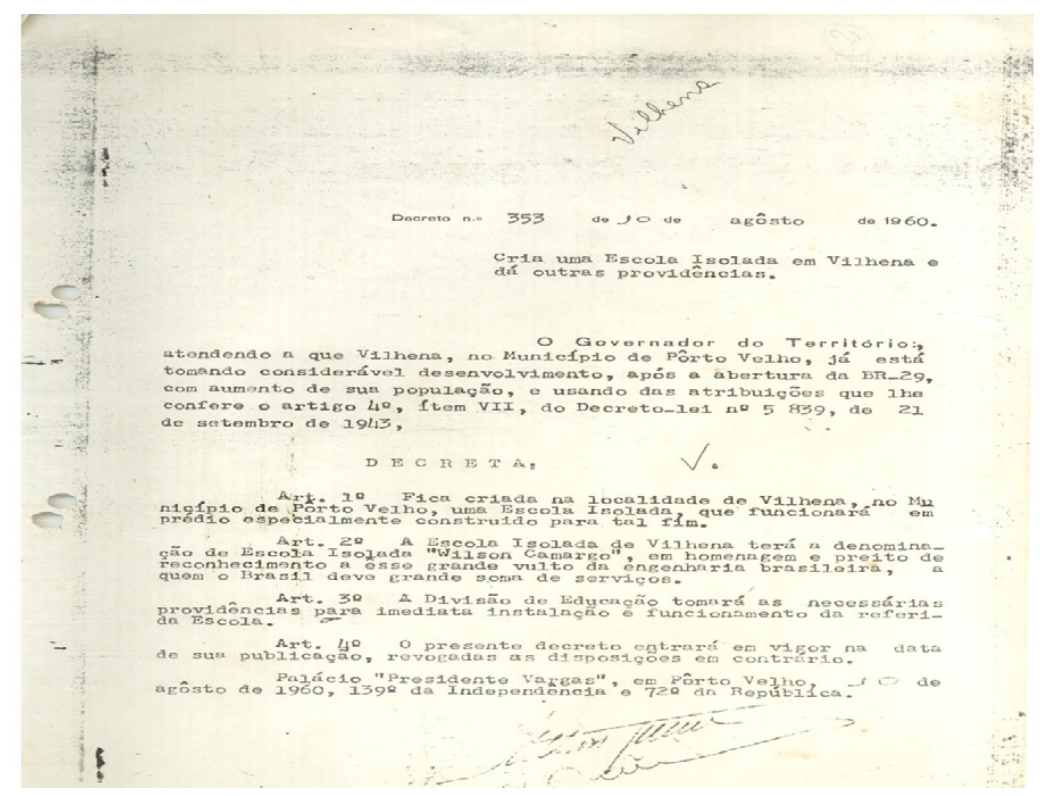

Fonte: Arquivo do Instituto Estadual de Educação Wilson Camargo.

Vale destacar ainda que as atividades escolares foram também organizadas na casa da professora Noeme. "A aula antes de chegar na escola foi na casa de uma professora que ensinava na casa dela, uma casa de madeirinha bem rústica e simples. Depois que veio a criaçáo da escolinha. E aos poucos foi ficando grande." (PROFESSORA BITELLO, Vilhena, 03/02/2017). Posteriormente, utilizou as estruturas da Força Aérea Brasileira (FAB), até por meados do final da década de 1960 ficando sob a responsabilidade da professora Noeme e sendo mantida pelo Território Federal de Rondônia (BRASIL, 2000).

No ano de 1970, a escola é mudada de localização e suas estruturas são firmadas na Avenida Capitão Castro espaço de permanência até os dias atuais, a escola possuía três salas, divididas da seguinte maneira: sala que foi usada para a diretoria, duas salas de aula, separado ao lado uma cozinha pequenina e um banheiro, sem energia elétrica e sem água encanada.

Minha primeira escola foi o Wilson Camargo, só existia ela. $\mathrm{Na}$ escola não tinha cerca, não tinha nada, não tinha muro, só tinha duas salas de aula e a minha sala de aula não me esqueço dela, porque tinha uma dispensa e nela guardava toda alimentação que chegava. Era uma época muito boa! (PROFESSORA DULCE, Vilhena, 14/07/2016). 
$\mathrm{Na}$ narrativa a professora Dulce descreveu que era a única escola e aos poucos foi sendo ampliada. A escola não tinha muita coisa, a água chegava até a escola com o auxílio de um caminhão pipa que abastecia alguns comércios, e o que sobrava abastecia o depósito de água da escola. A água se destinava para a manutenção da escola e para saciar a sede dos alunos. As dificuldades estavam relacionadas às mais diversas naturezas, além da pedagógica, a de cunho material era também uma dificuldade concreta que precisava ser superada.

\begin{abstract}
Tinha momentos que a gente náo tinha como escrever, porque náo tinha lápis. Eu ensinava desenhando na areia. A gente fazia prova oral, a gente dava um jeito. Era muito esquisito! Mas a gente se virava e os alunos se saíam bem pra caramba. Eles se saiam ótimos, parece que as ideias deles eram diferentes, eles tinham uma vontade de aprender. Os pais também cobravam muito, os pais ficavam em cima. (PROFESSORA BITELO, Vilhena, 03/02/2017).
\end{abstract}

A escola era respeitada pela sociedade, muitos a procuravam para arrumar emprego, para festividades, para o atendimento médico voluntário.

A escola era o centro de todas as coisas. Tudo que as famílias precisavam corriam para a escola que era sinal de muito respeito. Nós professores éramos muito respeitados. Parecia que a escola tinha que resolver todas as coisas, a gente se unia e tentava fazer o que dava conta. Nosso trabalho tinha cooperação. (PROFESSORA ARGEMIRA, Vilhena, 19/01/17).

A partir dessa narrativa, percebe-se a como a escola era de extrema necessidade social para a comunidade, havia uma atmosfera de respeito entre a sociedade que se formava e os funcionários da escola. A escola atendia náo só as necessidades formativas da comunidade, mas também as necessidades pessoais da sociedade através da cooperação. Ou seja, como dito por Leontiev (2004, p. 81) uma cooperação "assente na cooperação entre indivíduos que supóe uma divisão técnica, embrionária que seja, das funçóes do trabalho: assim, o trabalho é uma ação sobre a natureza, ligando entre si os participantes, mediatizando a sua comunicação".

A escola iniciava as atividades educacionais com o ensino de $1^{\mathrm{a}}$ a $4^{\mathrm{a}}$ série, com as atividades curriculares de Comunicação e Expressão e Matemática dando mais ênfase nas práticas da leitura e escrita. De acordo com as contribuiçóes de Brasil (2000, p. 113): 
[...] os primeiros anos de ensino eram destinados a preocupação de alfabetizar os alunos. $\mathrm{O}$ ensino era limitado a instruçóes nível primário, funcionando no estilo multisseriado, devido ao número reduzido de alunos, falta de recursos humanos e materiais. A pequena escola, porém, soube suprir e cumprir suas funçôes sociais naquele momento inicial.

O excerto discute a organização e preocupação em alfabetizar os alunos e como o ensino fora organizado para atender as necessidades da comunidade. No ano de 1966, a nomenclatura da disciplina de Comunicação e Expressão é alterada para Língua Portuguesa, como consta nos boletins. Com o número considerável de crianças, o espaço físico da escola se tornou pequeno e os responsáveis pela escola, junto ao Departamento de Educaçáo do Território, resolveram alugar uma casa ao lado da escola Wilson Camargo para o atendimento às crianças e adolescentes da região. Uma casinha simples, de madeira, assoalho, com mesas e carteiras feitas de tábuas longas que serviam de apoio para os dias de aula.

No ano seguinte foi alugada uma casinha de madeira para funcionar como sala de aula, tinha dois cômodos e era bem simplesinha. Essa ficava quase na esquina da quadra do lado da escola. As pessoas iam chegando de todos os lados e as salas foram ficando abarrotadas de gente. Nós não tínhamos carteiras o suficiente, eu levava um banquinho de casa e outras crianças levavam também, quem tinha. Montamos uns bancos com tábuas também. Estudamos no chão, sentávamos onde fosse legal para estudar. (PROFESSORA ÁUREA, Vilhena, 19/01/2017).

Para a realização da matrícula das crianças a escola cobrava uma taxa para o custeamento de recursos como materiais para a secretaria e higiene pessoal.

Quando as famílias iam fazer as matrículas dos filhos era cobrada uma taxa das matrículas, essa taxa era obrigatória. Mas, aqueles alunos que não tinham condiçóes nunca foram dispensados, alguém pagava ou eles arrumavam o dinheiro para pagar. Isso faz tempo, esse caixa era para comprar o que a escola precisasse. (PROFESSORA ARGEMIRA, Vilhena, 19/01/2017).

Uma ficha de inscrição com os dados pessoais do aluno e dos pais era quesito essencial para a matrícula do aluno. Como demonstra da figura de número 2. 
Figura 2 - Requerimento de matrícula da Escola Isolada Wilson Camargo, 1977.

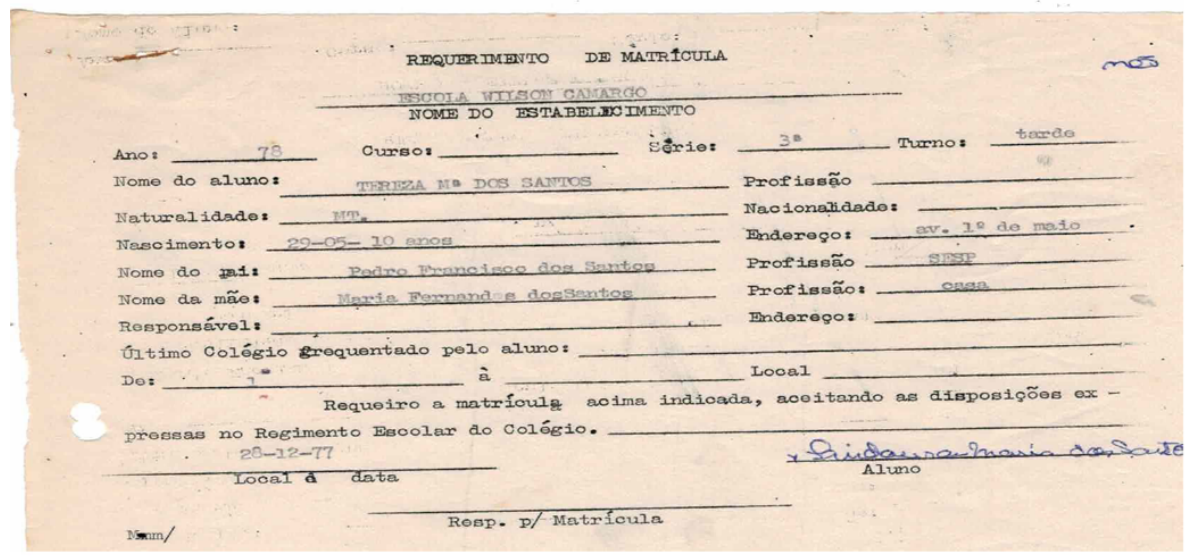

Fonte: Arquivo pessoal da autora (doação de entrevistada).

No ano de 1974 com a portaria de número 096\% $/$ SEC, de 04 de junho institui a $5^{\mathrm{a}}$ série do ensino de $1^{\circ}$ grau - passando a ter um atendimento do ensino de $1^{\circ}$ grau.

Tinha só até a $4^{a}$ série na escola, quando as crianças terminavam a $4^{\mathrm{a}}$ série náo tinha mais o que fazer. Eu juntei o pessoal da escola e falei: "vamos abrir a $5^{\text {a }}$ série, eu vou ser a professora de matemática”. Como eu tinha habilidade com números fui ser a professora. Os professores faziam tudo, limpava as salas, arrumava a merenda quando tinha. A Marisa Castiel era a representante da educação e ficava em Porto Velho, ela me chamava e eu atendia ao pedido dela que era para levar as fichas dos alunos. Todo mês eu pegava o "Búfalo" que era o aviáo do exército, e todo mês ele deixava o meu lugar e dizia: "Esse lugar aqui é da nossa diretora!" Eu trazia de volta alguns poucos materiais que eles davam. Eu enchia as caixas, e voltava de ônibus. Uma tortura! (PROFESSORA BITELO, Vilhena, 03/02/2017).

Analisando a narrativa da professora, podemos perceber que a iniciativa de ampliar os atendimentos de ensino partiu dos próprios professores, que percebiam a necessidade de formação para a sociedade. Ao término da $4^{\mathrm{a}}$ série,

6 INSTITUTO ESTADUAL DE EDUCAÇÃO WILSON CAMARGO. Portaria no 096, de 04 de junho de 1974. Dispóe sobre o atendimento do ensino de $1^{\circ}$ grau. Disponível no Arquivo Setorial da Educação. 
as crianças não tinham mais atividades na escola, muitas crianças partiam para o campo com a funçáo de ajudar o pai nas plantaçóes e no cuidado com os animais, ou, muitas vezes, dar continuidade ao trabalho do pai nas grandes fazendas.

A carga horária distribuída teria que atingir 180 dias letivos e 720 horas totais de aulas dadas, com um calendário que determinava o início das aulas em fevereiro e término em novembro. As aulas só eram dispensadas nos dias de feriados nacionais e estaduais e aos domingos. Os sábados eram contados como letivos, os professores se reuniam para fazer os planos de aula, rodas de conversa sobre as turmas e faxinas na escola. Com o tempo passou a ter algumas formaçóes com representantes da educação da capital e os sábados eram os dias marcados para essa qualificação.

As férias eram de acordo com o calendário anunciado pela secretaria de educação do Território. Os calendários escolares eram modificados de acordo com as instruçóes públicas ou qualquer alteração advinda da secretaria do Território. "A preocupação maior da escola se resumia na alfabetização dos alunos.” (BRASIL, 2000, p. 88).

A gente ensina Português e Matemática sempre, dava prioridades para essas disciplinas. Depois ensinava as outras disciplinas. Por exemplo, todos os dias tinha aula de português e matemática. Depois as outras aulas, mas a gente fazia assim, quando a gente trabalhava com textos (aula de português), já contava quantos personagens tinha para trabalhar com a (matemática), ou, e depois de um texto a gente já puxava para ciências e começava a falar dos animais. E assim, ia dando aulas, mas sempre com as iniciais que era português e matemática. (PROFESSORA ROSA, Vilhena, 20/01/2017).

De acordo com Sá (2007, p. 149), que o "primeiro preceito determinava a necessidade de reservar o primeiro período das aulas para as disciplinas que, segundo eles, requisitam maior esforço e atenção do aluno.” No decorrer das aulas, o segundo preceito era a escala de disciplinas que permitiam o descanso dos alunos como, por exemplo, a aula de ciências.

Para as turmas de Alfabetizaçáo e $1^{\text {a }}$ a $5^{\text {a }}$ séries, as disciplinas eram divididas da seguinte maneira: 
Tabela 1 - Distribuição das disciplinas $1^{\text {a e }} 5^{\text {a }}$ séries do $1^{\circ}$ Grau da Escola Wilson Camargo ano 1960-1970.

\begin{tabular}{l|c|c|c|c|c}
\hline Disciplinas & $\begin{array}{c}\text { Segunda- } \\
\text { feira }\end{array}$ & Terça-feira & $\begin{array}{c}\text { Quarta- } \\
\text { feira }\end{array}$ & $\begin{array}{c}\text { Quinta- } \\
\text { feira }\end{array}$ & Sexta-feira \\
\hline $\begin{array}{l}\text { Comunicação e } \\
\text { expressão }\end{array}$ & $X$ & $X$ & $X$ & $X$ & $X$ \\
\hline Matemática & $X$ & $X$ & $X$ & $X$ & $X$ \\
\hline Ciências & & & $X$ & $X$ & \\
\hline $\begin{array}{l}\text { Integração } \\
\text { Social }\end{array}$ & & & & & \\
\hline
\end{tabular}

Fonte: Produzido pela autora a partir dos relatos da professora Rosa (2017).

De acordo com a tabela organizada a partir das narrativas orais podemos observar a distribuição das disciplinas sendo que, a disciplina de Comunicação e Expressão e Matemática ocupam todos os dias de disciplina no decorrer das aulas, enquanto as outras disciplinas com: Ciências e Integraçáo Social acontecem com menos frequência e mais próximas ao final da semana, sendo que os alunos já apresentavam certo cansaço por serem mais estimulados na de Matemática e Comunicação e Expressão. Segundo os relatos orais das professoras, as disciplinas de Integração Social e Ciências eram dividas com atividades motoras realizadas no pátio da escola.

A gente não seguia método, seguia nossa intuição e o que a gente queria era fazer os alunos ler e escrever. Meu material de trabalho era o quadro. Eu trabalhava muito a mãozinha dos meus alunos, eles tinham que conseguir fazer as voltinhas das letras. Eu adorava porque eles tinham que fazer a letrinha certinha. Eu trabalhava muito a lateralidade da criança. Você sabia que isso tem que ser trabalhado? Então, eu amarava uma fitinha na mão direita de uma cor e na mão esquerda de outra cor. Levava eles para o pátio no dia de outra aula qualquer como, por exemplo, Ciências. Aí, eu trabalhava com as atividades motoras, mandando levantar a mão. Eu aprendi com as crianças! Conforme a dificuldade aparecia. (PROFESSORA ROSA, Vilhena, 20/01/2017). 
As atividades que regiam o ensino de $1^{\mathrm{a}}$ a $5^{\mathrm{a}}$ séries do $1^{\mathrm{o}}$ grau eram cobranças com relação à leitura e a escrita, memorização, leitura oral, tabuadas, horas, ditados e interpretação. As professoras mencionavam que tinham as atividades variadas que eram leituras silenciosas, textos construídos a partir de imagens, muitas caligrafias e para que as atividades fossem desenvolvidas com presteza as professoras elaboravam atividades motoras.

A escola só fez unir, mas por uma costura que muitas vezes ficou frágil, as duas capacidades, a de ler e a de escrever. Com efeito, elas estiveram por muito tempo separadas no passado, até durante um bom trecho do século XIX; hoje, a vida adulta dos escolarizados dissocia aliás bem depressa, em muitos, o 'ler apenas' e o escrever. (CERTEAU, 2012, p. 239).

Com a criação das demais turmas, as atividades curriculares eram regidas sob a Lei de no 5.692/71 que traçavam modalidades de disciplinas e preparação para as necessidades do mercado do trabalho local ou regional. Para as turmas de $6^{\mathrm{a}}$ a $8^{\mathrm{a}}$ série do $1^{\mathrm{o}}$ grau eram Língua Portuguesa; Matemática; Ciências; História; Geografia; Educação Moral e Cívica; Religião; Educação Física; Técnica Industrial; Técnica Comercial; Educação Artística; Educação para o Lar; Inglês; Organização Social e Política Brasileira (OSPB).

As aulas que pareciam ser "optativas", mas que não eram tão optativas, como por exemplo, as de Ensino Religioso, eram cuidadosamente orientadas por formadores como padres, irmãs que tivessem parceria ou vínculo com o Mistério da Educação e Cultura da capital. As aulas formativas eram direcionadas à fé cristâ, aos cuidados e ajuda ao próximo.

A aula de Higiene e Religião era colocada na grade curricular e vinha uma irmã de Porto Velho para dar formação para nós, ela passava para nós como era para ser dada as aulas e tinha que ser do jeito que ela falava. Em Ensino Religioso a gente não trabalhava falando de Santos, a gente trabalha no geral falando de Deus. Mas era uma irmã que vinha quando ela não vinha chegava o padre. Depois de um tempáo que começou a vir um pastor e ficou legal os debates. (PROFESSORA ARGEMIRA, Vilhena, 19/01/2017).

Com a Resolução de no 15/CTE no dia 19 de outubro de 1976, ficou oficialmente registrada e autorizada a criação, funcionamento e reconhecimento do Pré-escolar na escola. No ano subsequente, com o Parecer no 032/CTE/1977 de 29 de setembro, ficou autorizado o funcionamento dos cursos de Magistério de $1^{\mathrm{a}}$ a $4^{\mathrm{a}}$ séries e Auxiliar de Contabilidade. 
Para que a implementação dos cursos formativos e de habilitação em Magistério e Auxiliar em Contabilidade fosse aceito, no ano de 1977 foi elaborado um processo de análise e estruturação de professores.

Foi ainda disposto no documento que com o aumento considerável da demanda escolar, implicaria na necessidade de abertura de novas escolas. A implementaçáo do $2^{\circ}$ grau se justificava na necessidade de formar e suprir as necessidades da sociedade que se formava, pois, o deslocamento de outros professores para a regiáo era dispendioso. Para a abertura do curso de Auxiliar em Contabilidade se justificou por perceber o crescimento e desenvolvimento da regiáo com o Projeto do INCRA, o surgimento de empresas agroindustriais e várias ativaçóes de comércios.

Com a criação dos cursos técnicos a escola passou a atender um número maior de alunos de todas as regióes vizinhas e tinha como prioridade a formação técnica para a execução e manutenção da demanda de trabalho. A continuidade e permanência das pessoas nas áreas rurais passaram a ser responsabilidade da escola.

A escola tinha a funçáo de formar pessoas de todos os lugares. Mas, a gente dava prioridade para formar os alunos em magistério que moravam nos sítios. Porque depois, de formados, eles podiam ajudar nas escolas, como professores. (PROFESSORA ARGEMIRA, Vilhena, 19/01/2017).

Aqueles que possuíam condiçóes financeiras, garantiam uma educação para seus filhos fora da cidade, os que não tinham esse privilégio reproduziam a sistemática organização das suprimidas liberdades capitalistas.

Justifica-se pensar aqui na consagração desse ensino dual, e na oficializaçáo da distância que se mostrava na prática, entre educaçáo da classe dominante (escola primária acadêmica e escolas superiores) e a educaçáo do povo (escola primária e escola profissional). Esse reflete o dualismo que opera o retrato da organização social brasileira (ROMANELLI, 2010, p. 42).

Quando eu cheguei já existia a escola Wilson Camargo, mas estava lotada. Eles alugaram uma casa de madeira que ficava no meio da outra quadra. Enfim, perto da escola! Era de madeira e tinha duas salinhas, eu estudava a noite. Minha mãe estranhava porque eu e minha irmã éramos de idades diferentes, mas dividíamos as mesmas salas. O horário de aula era das sete às dez da noite. Acho que o horário era assim, porque tinha muita gente que trabalha na serraria. E porque desligava a energia, bem depois que a escola conseguiu comprar um gerador. (SPAGNOLLO, Vilhena, 18/01/2017). 
A escola passou a executar as atividades no período noturno, porém, enfrentando os desafios cotidianos, como a falta de iluminaçáo. As aulas tinham que terminar às 22horas porque os geradores da Central de Energia Elétrica de Rondônia (CERON) só tinham condiçóes para ativação da prestação de serviço até esse horário.

A professora Argemira, narra em suas memórias, que foi uma festa quando a escola conseguiu comprar um motor gerador de energia. Relata ainda que conseguiram após muito trabalho com organização de festas, rifas e doaçóes. Segundo suas palavras:

No primeiro ano a energia da escola Wilson Camargo era desligada às dez da noite, os alunos ficavam de olho no relógio, porque a gente tinha que soltar um pouquinho mais cedo. Entáo, era um prejuízo muito grande, para os professores e para os alunos. Náo dava tempo de passar todo o conteúdo, os alunos não conseguiam ter muito proveito. Imagina. Entrava às sete da noite até todos se organizarem e logo já terminava. A gente trabalhava de unhas e dentes para a escola. $\mathrm{Na}$ época de festas juninas a gente se reunia e organizava a festa. Trabalha muito porque nosso objetivo era comprar um gerador de energia. Foi uma festa só, o dia que conseguimos comprar. Fizemos a casinha, colocamos. Quando estava perto do horário de desligar e energia da CERON, a gente já ficava na porta da casinha para ligar o nosso gerador. Foi muito legal! (PROFESSORA ARGEMIRA, Vilhena, 19/01/2017).

Novamente a escola sofre alteração no nome, no dia 06 de outubro de 1977 com o Parecer de no 033/CTE/1977, passando a se chamar Escola Territorial de $1^{\circ}$ e $2^{\circ}$ graus Wilson Camargo. No ano de 1989 a escola foi reconhecida como Escola de $1^{\circ}$ e $2^{\circ}$ graus "Wilson Camargo" e, no decorrer do ano de 1993, com o Decreto de no 5956, a escola é elevada a Instituto Estadual de Educaçáo Wilson Camargo. No ano de 1996, em 11 de dezembro, com a Resolução no 074/CEE/RO/1996 é alterado a denominação da escola.

A estrutura da escola foi sendo aos poucos organizada, da mesma maneira que a sociedade. A adaptaçáo dos professores e alunos ia sendo aprimorada e adequada à realidade cotidiana de "toda poeira e suor da cidade" (CERTEAU, 2012, p. 71). Portanto, pensar a implementação da educação é pensar também na migração, pois estão correlacionadas.

Podemos assim, dizer que a educação estava ligada ao pleno processo de colonização e desenvolvimento da cidade, sendo a escola a principal referência de formação para a sociedade. 
As narrativas nos possibilitaram contribuições de leitura do passado, e nesse viés, nota-se, que "[...] somente assim podemos compreender que uma lembrança seja ao mesmo tempo reconhecida e reconstruída.” (HALBWACHS, 2015, p. 39), e como estáo articuladas em torno dos acontecimentos tanto individuais como dos acontecimentos coletivos.

A tentativa de recordar as memórias da educação nos possibilita perceber a trajetória histórica que ainda está viva na memória das pessoas que estiveram presentes na sociedade e que náo foram deletadas, nem mesmo esquecidas. Construir e (re)compor esse percurso é dizer que as memórias são cheias de sentidos e pertencem ao mundo das experiências do passado.

\section{Considerações finais}

"[...] O futuro, tal como o passado, atrai os homens de hoje, que procuram suas raízes e sua identidade e, mais que nunca os fascina [...]", como dito por Le Goff (2013, p. 213). No desenvolvimento da pesquisa o fascínio pelos momentos vivenciados nos promoveram diversos tipos de sensaçóes de aprendizados e reflexóes acerca do novo, da descoberta, do passado, das contradiçóes que foram experiências significativas para a escrita dessa pesquisa. Ao nos lançar no campo empírico, o futuro e o passado nos atraíram, nos permitindo compreender inquietaçóes e acima de tudo maneira(s) de pensar sobre as nossas "raízes" e a nossa "identidade".

Podemos perceber que a migração está diretamente ligada ao processo educacional do município, sendo que a sociedade ganha massa populacional com a abertura da BR 364. Diversos eram os tipos de necessidades, porém tomamos como foco a educaçáo para o estudo dessa pesquisa, uma vez que a escola era considerada pelos trabalhadores migrantes como almejo para mudança e condiçóes de melhoria na vida dos filhos. Táticas governamentais estavam diretamente ligadas ao processo de migração e diversos meios foram utilizados para manipular o incentivo do acelerado processo de ocupação, e ainda vale mencionar sobre a integração dos "espaços vazios”", que negam a existência de ribeirinhos, seringueiros e indígenas na região.

O desenvolvimento do presente estudo nos possibilitou perceber que muitas eram as dificuldades que conviviam com a educaçáo de Vilhena, entre elas estavam a falta de materiais escolares, a ausência de materiais didáticos,

7 De acordo com Peripolli (2009, p.57), “[...] era a filosofia implantada pela Escola Superior de Guerra, criada em 1949, com a finalidade de elaborar uma Doutrina de segurança Nacional. Como, de fato, foi implantada, mais tarde, pelos militares, após o golpe de 1964". 
a inexistência de formação profissional e metodológica, a falta de recursos humanos para o trabalho docente, a falta de água, energia elétrica e a própria estrutura escolar.

Em uma simples casinha de madeira, a escola começa a funcionar e a resistir a todas as precariedades. Os professores leigos que assumiram a educaçáo ocupavam um lugar de luta constante e sobrepujamento. Aprendiam nas maneiras cotidianas os modos de fazer e ensinar as crianças que se tornavam alunos aprendia, mas também ensinava a arte do movimento do aprendizado.

Aqui, nessa pesquisa, ficou não só os registros, mas todos os sorrisos, olhares, desconfiança, vitórias e choros desses que se dedicaram aos modos de lembrar e contar a partir do "[...] som do assoalho da escola e a saudade das peraltices das crianças. Ainda escuto [...].” (PROFESSORA JAROLA, Vilhena, 19/01/2017).

\section{Referências}

BAENINGER, Rosana; CUNHA, José Marcos Pinto da. A migraçáo dos estados brasileiros no período recente: principais tendências e mudanças, 2008. Disponível em: http://www.abep.nepo.unicamp.br/docs/anais/ outros/2EncNacSobreMigracao/Anais2ENSMigracaoOuroPreto1999p117a167. pdf. Acesso em: 04 de junho 2017.

BRASIL, Pedro. Vilhena conta sua história. Vilhena: Gráfica Delta, 2000.

BRASIL. Decreto n. 5956, de 27 de Maio de 1993. Dispóe sobre as escolas Estaduais de $1^{\circ}$ e $2^{\circ}$ graus "Marechal Rondon", em Ji-Paraná e "Wilson Camargo", em Vilhena, e dá outras providências. Disponível no Arquivo Setorial da Educação.

BRASIL. LDB. Lei n. 5.692, de 11 de agosto de 1971. Dispóe sobre a fixação de Diretrizes e Bases para o ensino de $1^{\circ}$ e $2^{\circ}$ graus. Disponível em: http:// www.planalto.gov.br/ccivil_03/leis/L5692.htm. Acesso em: 14 de junho 2017.

BRASIL. Portaria n. 032, de 29 de setembro de 1977. Dispóe sobre a autorizaçáo e atendimento do Curso de Magistério de $1^{\text {a }}$ a $4^{a}$ séries e Auxiliares de Contabilidade. Disponível no Arquivo Setorial da Educação.

BRASIL. Portaria n. 033, de 06 de outubro de 1977. Dispóe sobre a alteração no nome da escola, passando a Escola Territorial de $1^{\circ}$ e $2^{\circ}$ graus Wilson Camargo. Disponível no Arquivo Setorial da Educação. 
BRASIL. Portaria n. 074, de 11 de dezembro de 1996. Dispóe sobre a alteração no nome da escola, passando Instituto Estadual de Educação Wilson Camargo. Disponível no Arquivo Setorial da Educação.

BRASIL. Portaria n. 15, de 19 de outubro de 1976. Dispóe sobre a autorização e reconhecimento do pré-escola. Disponível no Arquivo Setorial da Educação.

CAMBI, Franco. História da pedagogia. São Paulo: UNESP, 1999.

CERTEAU, Michel de. A invençáo do cotidiano: 1 . Artes de fazer. 19. ed. Rio de Janeiro: Vozes, 2012.

CORALINA, Cora. Poemas dos becos de Goiás e estórias mais. São Paulo: Parma Ltda, 1983.

CUNHA, Maria Isabel da. Conta-me agora! as narrativas como alterativa pedagógica na pesquisa e no ensino. Revista da faculdade de educaçáo. São Paulo, v. 23, n. 1-2, jan. 2015.

DELGADO, Lucilia de Almeida Neves. História oral: memória, tempo, identidades. 2. ed.BeloHorizonte:Autêntica2010.Disponívelem:http://www. scielo.br/scielo.php?script=sci_arttext\&pid=S0102-25551997000100010. Acesso em: 04 de junho 2017.

FREITAS, Sônia Maria de, História oral: possibilidades e procedimentos. 2. ed. São Paulo: Associação Editorial Humanista, 2006.

GOLDER, Mario. Leontiev e a psicologia histórico-cultural: um homem em seu tempo. São Paulo: Grupo de estudos e Pesquisas sobre Atividades pedagógicas, 2004.

HALBWACHS, Maurice. A memória coletiva. São Paulo: Centauro, 2015.

LE GOFF, Jacques. História \& memória. 7. ed. São Paulo: Unicamp, 2013.

LEONTIEV, Alexis. O desenvolvimento do psiquismo. 2. ed. São Paulo: Centauro, 2004.

MÉSZÁROS, István. A educação para além do capital. 2. ed. São Paulo: Boitempo, 2008.

PERDIGÃO, Francinete; BASSEGIO, Luiz. Migrantes amazônicos. Rondônia: A trajetória da ilusão. São Paulo: Loyola, 1992. 
PERIPOLLI, Odimar João. Expansão do capitalismo na Amazônia Norte Mato-Grossense: a mercantilização da terra e da escola. Porto Alegre: PPGDU/UFRGS, 2009.

ROMANELLI, Otaíza de Oliveira. História da educação no Brasil (19301973). 31 ed. Rio de Janeiro: Vozes, 2010.

SÁ, Elizabeth Figueiredo. De criança a aluno: as representaçóes da escolarização da infância em Mato Grosso (1910-1927). Cuiabá: EdUFMT, 2007. 


\section{Capítulo 5 \\ FORMAÇÃO DO MAGISTÉRIO RURAL EM RONDÔNIA NAS DÉCADAS DE 1970 E 1980: ALGUNS ACHADOS...}

Roger dos Santos Lima Josemir Almeida Barros

\section{Introdução}

Este texto ${ }^{1}$ corresponde a um recorte da pesquisa de mestrado, alicerçada na História e Historiografia da Educação, no que diz respeito à formação e profissão de professoras e professores rurais em fins do século XX. O texto justifica-se, pois segundo as pesquisas de Leite (1999), Piacentine (2012) e Prado (2017) poucos estudos evidenciam a história da educação rural, e quando se trata da formação e/ou profissão docente este número tende a diminuir, sendo importante o estudo da temática.

Deste modo, a problemática que nos inquietou foi a seguinte: qual a principal política de formação do magistério rural nas décadas de 1970 e 1980 em Rondônia? Nosso objetivo foi analisar as principais políticas de formação do magistério rural ocorridas nas décadas de 1970 e 1980 em Rondônia.

Os documentos consultados incluíram leis, decretos, pareceres, instruçáo normativa, resolução e matéria em jornal, além de estatísticas educacionais. As instituiçóes na qual realizamos o levantamento foram: Centro de Educação de Jovens e Adultos de Ariquemes (Ceeja); Biblioteca Municipal Pedro Tavares Batalha; Museu Marechal Rondon (ambos em Ariquemes); e, Casa Civil de Rondônia (sitio online).

Em relação ao referencial teórico-metodológico, atualmente duas linhas teóricas têm constituído os estudos historiográficos, a primeira corresponde no marxismo, no qual a economia é representada pelos modos de produção e, a história nova ${ }^{2}$ (que diverge da história positivista e em parte do marxismo),

1 A pesquisa contou com financiamento da Coordenação de Aperfeiçoamento de Pessoal de Nível Superior (CAPES).

2 A história nova surgiu com a Escola dos Annales com Lucien Febvre e Marc Bloch, quando lançaram em 1929, em Estrasburgo uma revista a Annales d'histoire économique et sociale, um projeto de Lucien Febvre. (LE GOFF, 1995). Em 1980 com Jacques Le Goff na diretoria da escola e, a partir da publicação do Livro (a história dos problemas) a roupagem da revista tomou um novo caminho. 
apresentando uma renovação metodológica nos procedimentos de análise da história. Com relação à história nova destaca-se que:

\begin{abstract}
A história nova ampliou o campo do documento histórico; [...] fundada essencialmente nos textos, no documento escrito, por uma história baseada numa multiplicidade de documentos: escritos de todos os tipos, documentos figurados, produtos de escavaçōes arqueológicas, documentos orais, etc. (LE GOFF, 1995, p. 28).
\end{abstract}

Os estudos que compóem a teoria mencionada tendem a interpretar as fontes analisadas numa perspectiva crítica, desvelando assim as "ideologias" presentes nos documentos. Acreditamos que recuperar e/ou (re)constituir a história corrobora para avançar para além daquela perspectiva apresentada por Bloch (2001, p. 58) na qual "[...] o passado só foi empregado tão ativamente para explicar o presente no desígnio do melhor justificar ou condenar”. Portanto, resgatar a história da formação do magistério rural, possibilita um novo conhecimento historiográfico, não somente a respeito de o magistério rural, mas também para a História da Educação em Rondônia.

\title{
Formação de professores rurais na primeira metade do Século XX em Rondônia
}

A História da Educação e, consequentemente a história da formação de professoras e professores rurais, no que hoje configura o estado de Rondônia deu-se início nos primórdios do século XX.

Lima (1993) ao descrever a educação em Rondônia, declarou que a primeira escola pública fundada foi a Escola Municipal de Santo Antônio, em 1913, localizada na cidade de Santo Antônio do Alta Madeira, na época estado de Mato Grosso. Ainda segundo o autor, outras instituiçóes de ensino poderiam ter sido construídas anteriormente, entretanto o "Poder Público" se eximia dessa responsabilidade, justificando o difícil acesso à localidade, a dispersão populacional no imenso espaço geográfico e, a ausência de aglomerados de indivíduos.

Barros (2018) expôs que é possível verificar que as políticas que emergiram na Primeira República (1989-1930) no Brasil, foram deliberadas, sobretudo, a partir de anseios das classes dominantes que ao se preocuparem com a educaçáo, visavam principalmente o atendimento de modo restrito e preferencial às populaçóes urbanas, ou seja, "as escolas localizadas no meio rural serviam [...] de apoio para os politiqueiros e muitas de suas açóes visavam 
exclusivamente angariar votos". (BARROS, 2018. p. 395). Assim, as escolas rurais serviam como meio de barganha política e os investimentos públicos inclinavam-se para a troca de votos. Lima (2019) também aceverou sobre as representaçóes da escola rural.

Com isso, os problemas e inseguranças cresciam nas escolas rurais e elas se encontravam em abandono.

As adversidades encontradas pela educação rural são muitas, entre elas pode-se citar a precariedade e falta de escolas, as distâncias e a falta de comunicação das poucas escolas existentes, a falta de orientação metodológica e didática, bem como a ausência de verbas públicas na escolarização. Entre todas essas precariedades, não se pode deixar de mencionar a deficiência de professores e formaçáo dos poucos docentes existentes. (PIACENTINE, 2012, p. 37).

Não obstante, os discursos da época dividiam o mundo urbano e rural. O rural era/é associado ao atraso, ao ignorante, com ausência de políticas públicas $^{3}$ voltadas a seu desenvolvimento. Já o mundo urbano era o mundo civilizado, moderno, a referência dos modelos culturais e maestro das decisóes políticas e econômicas.

No que concernia às instituiçóes formativas para o professorado rural, na primeira metade do século XX em Rondônia, identificamos a dissertação elaborada por Fernanda Batista do Prado (2017) sobre a Escola Normal Rural Nossa Senhora Auxiliadora, criada em 1930, como Escola Paroquial, voltada para uma educaçáo pautada nos dogmas salesianos. A escola entre os anos de 1937 a 1946, ofertou o Curso Normal Rural, nível ginasial para habilitação do magistério.

Os estudos realizados por Werle (2012), sobre as Escolas Normais Rurais, instituídas nas décadas de 30, 40 e 50 do século XX, demostraram que o propósito dessas instituiçôes voltava-se para a formação de professoras e professores para a docência em escolas do interior, ou seja, escolas rurais que muitas vezes funcionavam em locais isolados, com uma única sala de aula e um professor.

Contudo, a partir do que descreve Araújo (2011) sobre a criação da primeira escola de formação de professoras e professores ruralistas do Brasil em Juazeiro do Norte, é possível inferirmos que as escolas rurais constituídas

3 “[...] política pública é uma orientação à atividade ou à passividade de alguém; as atividades ou passividades decorrentes dessa orientação também fazem parte da política pública; uma política pública possui dois elementos fundamentais: intencionalidade pública e resposta a um problema público; [...]" (SECCHI, 2012, p. 2). Neste caso, o poder público não considerava a educação rural e/ou a formação do professorado rural um problema público, ou ainda, as precariedades existentes na escola rural, como um problema público da maioria da população. 
nas primeiras décadas do século $\mathrm{XX}$ no Brasil não se caracterizavam em uma 'escola nacional pública'.

Para que o país pudesse crescer e evoluir era, pois, necessário criar uma nova estrutura escolar, rompendo com os modelos "estrangeiros". Essa escola "[...] deveria levar o brasileiro a se tornar o homem adaptado ao meio em que vivia, fornecendo-lhe uma mudança de mentalidade capaz de fazêlo sentir e acreditar em sua força criadora, na busca crescente da melhoria de vida." (ARAÚJO, 2011, p. 241).

Além da Escola Normal Rural Nossa Senhora Auxiliadora, outra instituição de ensino também oferecia curso de habilitação ao professorado rural, a saber, o Instituto Nossa Senhora do Calvário, criado em 1933 por Dom Xavier Reis, bispo da prelazia. O Instituto era dirigido pela madre francesa Marta do Calvário e tinha como meta a formação de moças, que uma vez formadas iriam atuar em escolas rurais. (SOUZA, 2017). Em seus primórdios o instituto oferecia “[...] ensino primário ao alunado feminino em regime de externato e internato. Em 1940, passou a oferecer o Curso Normal Rural de nível ginasial, para a formação de professores do ensino primário." (LIMA, 1993, p. 14).

Convém alentar que as primeiras prescriçóes concretas, com relação à formação de professoras e professores rurais, foi a partir da promulgação da Lei 4.024 de 20 de dezembro de 1961, estabelecendo no capítulo IV, normas regulamentárias quanto à formação do magistério. Assim descreve o Art. 57 sobre a formação do magistério no meio rural "A formação de professores, [...] para as escolas rurais primárias poderá ser feita em estabelecimentos que lhes prescrevem a integração no meio." (BRASIL, 1961). Além do trecho, composto na Lei, o Art. 105 alentava que, era de responsabilidade do Estado ${ }^{4}$ instituir e amparar as escolas que ele mantinha no meio rural, proporcionando lhes uma educaçáo compatível ao homem do campo. (BRASIL, 1961).

Com a publicaçáo do Decreto no 426 de 04 de novembro de 1964, criou-se em Porto Velho o Centro de Treinamento de Professores Rurais de Rondônia. $\mathrm{O}$ Art. $2^{\circ}$ do referido decreto apresenta-se o seguinte excerto: "O Centro de Treinamento de Professores Rurais de Rondônia destina-se a elevar o nível cultural dos professores leigos das zonas rurais do Território, habilitando-os

4 Entende-se aqui por Estado àquela "[...] instituiçấo que, acima de todas as outras, tem como função assegurar e conservar a dominação e a exploração de classe.” (BOTTOMORE, 1988, p. 217). Ou seja, mesmo agraciando a sociedade com políticas sócias, seu intuito será unicamente em manter a ordem e a manutenção das relações capitalistas. 
ao pleno exercício do magistério". (RONDÔNIA, 1964). Além de habilitar o professorado leigo ${ }^{5} \mathrm{da}$ área rural, este centro oferecia bolsas de estudos para custear as despesas de alimentação e locomoção dos docentes.

Com o Projeto Integrado de Colonizaçáo (PIC) instituído pelo Instituto Nacional de Colonização e Reforma Agrária (INCRA), nos anos de 1970, marcou-se o início das grandes transformaçóes econômicas, sociais e políticas em Rondônia. (TEIXEIRA; FONSECA, 2001). Em virtude disso um grande contingente populacional migrou para a regiáo (cerca de $20 \%$ ao ano), consequentemente o número de escolas se expandiu, logo os docentes leigos imperavam nessas escolas.

Visando capacitar/habilitar os professores e professoras da região, o Governo do Território adotou um grande projeto de formação de professores leigos, o Projeto Logos I e o Logos II, que marcou a história da formação docente no meio rural em Rondônia nos anos de 1970, 1980 e início dos anos de 1990.

\section{O experimento: Projeto Logos I}

Com a necessidade de formar professores leigos em Rondônia, o estado aderiu ao Projeto Logos I, inicialmente como um experimento para que posteriormente fosse implantado o Logos II, executado a nível nacional.

O projeto-piloto correspondeu a uma ação do Departamento de Ensino Supletivo do Ministério da Educação (DSU/MEC), com a gerência técnica do Centro de Ensino Tecnológico de Brasília (CETEB) (BRASIL, 1975). O objetivo era habilitar professoras e professores leigos que lecionavam nas séries iniciais do primeiro grau ( $1^{\mathbf{a}}$ a $\left.4^{\mathbf{a}}\right)$, sem retirá-los da sala de aula, por meio de a utilização de módulos e de encontros pedagógicos mensais para avaliação. $\mathrm{O}$ Logos I foi implantado nos estados da Paraíba, Piauí, Rio Grande do Norte e nos territórios de Rondônia e Roraima.

Segundo o Parecer no 0001, relatado por Magna França de Queiroz, em 07 de fevereiro de 1983, o Projeto tinha amparo legal na "[...] Lei 5.692/71, Pareceres 45/72 e 853/72 - CEF/MEC que normatizam o exercício do Magistério em $1^{\circ}$ Grau com Habilitação Específica de $2^{\circ}$ Grau em consonância com o Parecer 699/72 que doutrina o Ensino Supletivo." (PARECER No. 0001/CEE/RO/83, p. 01).

5 Entende-se por professorado leigo aquele “[...] que leciona sem ter feito ou concluído o curso que o habilita ao exercício do magistério no nível de ensino em que atua. Aplica-se em geral a professores de $1 .^{\circ}$ grau que não cursaram ou concluíram o antigo curso normal (atuais cursos de formação do magistério em nível de 2. ${ }^{\circ}$ grau).” (DUARTE, 1986, p. 141). 
As exigências foram prescritas nas Diretrizes e Bases para o ensino de $1^{\mathrm{o}} \mathrm{e}$ $2^{\mathrm{o}}$ graus, Lei no 5.692 de 11 de agosto de 1971, que no Art. 30 exigia como formação mínima para o exercício do magistério:
a) no ensino de $1^{\circ}$ grau, da $1^{\text {a }}$ à $4^{a}$ séries, habilitação específica de $2^{\circ}$ grau;
b) no ensino de $1^{\circ}$ grau, da $1^{\text {a à }} 8^{a}$ séries, habilitaçáo específica de grau superior, ao nível de graduação, representada por licenciatura de $1^{\circ}$ grau obtida em curso de curta duraçáo;
c) em todo o ensino de $1^{\circ}$ e $2^{\circ}$ graus, habilitação específica obtida em curso superior de graduaçáo correspondente a licenciatura plena. (BRASIL, 1971).

A Lei de Diretrizes de Bases de 5692 de 1971, embora abrisse espaço para a educação rural, no $\S 2^{\circ}$ do Art. 11 e todo o Art. 49, teoricamente não conseguiu atingir os objetivos propostos pela legislação, isso porque a lei distanciava-se da realidade sociocultural do rurícola brasileiro, não incorporando, assim, “[...] as exigências do processo escolar rural em suas orientaçóes fundamentais nem mesmo cogitou possíveis direcionamentos para uma política educacional destinada, exclusivamente, aos grupos campesinos". (LEITE, 1999, p. 47-48). Diversas eram as problemáticas ligadas ao meio rural, desde: aspectos sócio-políticos; instalaçôes físicas e materiais; ausência de políticas educacionais, entre outros fatores.

O documento de Avaliação do Projeto Logos I, Brasil (1975), ao mencionar o dado da Divisão de Educaçáo dos Territórios descreveu que no ano de 1971, no Território Federal de Rondônia havia um total de 299 professores titulares e, 668 professores não titulares, ou seja, 223,41\% dos docentes na época eram 'leigos'. Corroborando, o Grupo Funcional de Programação e Controle Curricular da Secretária de Educaçáo e Cultura (SEC) de Rondônia apresentou (Quadro 01) o quantitativo de docentes com e sem formação até maio de 1977.

Quadro 01 - Percentual de professores, segundo sua formação e zona onde atuam.

\begin{tabular}{|c|c|c|c|c|c|c|}
\hline \multirow{2}{*}{ ESPECIFICAÇÃO } & \multicolumn{3}{|c|}{$\begin{array}{c}\text { Professores com Formação } \\
\text { Pedagógica }\end{array}$} & \multicolumn{3}{c|}{$\begin{array}{c}\text { Professores sem Formação } \\
\text { Pedagógica }\end{array}$} \\
\cline { 2 - 7 } & Urbano & Rural & Total & Urbano & Rural & Total \\
\hline \multirow{2}{*}{ Número } & 644 & 144 & 758 & 269 & 609 & 905 \\
\hline
\end{tabular}

Fonte: RONDÔNIA - Serviço de Supervisão SEC/RO (1977, p. 32). 
O quadro acima demostra que do total de docentes de $1^{\underline{o}}$ e $2^{\underline{o}}$ graus do território $54,4 \%$ não possuía "formação pedagógica", quando referido a área urbana o índice de docentes sem habilitação chegava a 32,7\%, já nas áreas rurais o percentual de professores não habilitados é gigantesca $67,3 \%$.

Curioso é a constatação de que, embora já houvesse, no período, cursos de formaçáo de professores, o aumento de professores atuando com apenas o primeiro grau incompleto aumentou muito mais do que os que possuíam pelo menos o primeiro grau completo. (GONÇALVES, 2015, p. 128).

Dentre os fatores que ocasionava o alto índice de docentes leigos nas áreas rurais, no Território Federal de Rondônia destacam-se: a dificuldade de acesso as escola; precariedade no serviço de supervisão/inspeção; isolamento do docente dificultando o seu crescimento profissional e, poucos recursos humanos. Assim, via-se com urgente a qualificação/profissionalização do professorado rural de Rondônia.

A primeira edição do Projeto Logos em Rondônia segundo o Parecer no 0001 de 1983 iniciou em 1975 e foi até 1981, atingindo um total de duzentos e cinquenta e cinco cursistas (255) concluintes (PARECER No. 0001/CEE/RO/83, p. 01). As cidades 'agraciadas' com o Projeto Logos I foram: Porto Velho, Guajará-Mirim, Cacoal e Vila Rondônia, este último atual município de Ji-Paraná.

Em uma matéria divulgada no Jornal $O$ Parceleiro, intitulada "SEC expande projeto logos II”, relata o sucesso obtido com o projeto fazendo com que:

[...] a Secretaria de Educação a fornecer este benefício, visando uma melhor qualidade de ensino, a toda população escolar. Neste sentido a SEC está estudando a implantaçáo de novos Núcleos do Projeto Logos II em Rondônia, Colorado e Vilhena serão as localidades beneficiadas, também se pretende iniciar novas turmas em Porto Velho e Ji-Paraná. (SEC, 1979).

Deste modo, o projeto-piloto (Logos I) na buscava de uma viabilidade da metodologia, que correspondesse de forma eficaz e eficiente para formar/ habilitar os professores leigos rurais nas unidades federativas do Brasil, e averiguado os dados apresentados no Logos I, expandiu-se o projeto para o Logos II. 


\section{O sonho tornou-se realizade? Projeto Logos II}

Detectado a eficácia do projeto-piloto, o qual habilitou mais da metade dos cursistas, a Subsecretaria de Ensino Supletivo ampliou o Projeto Logos. Segundo o CETEB a execução do Logos II foi expandida para dezenove (19) unidades da Federação, a saber: "Acre, Amazonas, Bahia, Ceará, Maranhão, Mato Grosso, Mato Grosso do Sul, Minas Gerais, Pará, Paraíba, Paraná, Piauí, Pernambuco, Rio de Janeiro, Rio Grande do Norte, Rondônia, Santa Catarina e Sergipe e, ainda, ao então território de Roraima” (CETEB, 1984, p. 56).

O Logos II em Rondônia foi aprovado para execução em 1983, a partir da Resoluçáo no 00002 de 17 de fevereiro do mesmo ano para “[...] ser executado pela Secretaria de Estado da Educação em conjunto com o Departamento de Ensino Supletivo-DESU/SEDUC." (RESOLUÇÃO No. 00002/CEE$\mathrm{RO} / 83$, p. 01). O curso seguia as determinaçóes e exigências dos programas de $5^{\mathrm{a}}$ a $8^{\mathrm{a}}$ séries do primeiro grau e de $1^{\mathrm{a}}$ a $3^{\mathrm{a}}$ séries do segundo graus, além de conteúdos pedagógicos.

O curso era programado para que o cursista o encerrasse em trinta (30) meses. Quem poderia cursar o Logos II? Segundo os estudos realizados por Gonçalves (2015, p. 131) sobre a profissão docente no meio rural "estavam aptos a cursar o Logos II professores em efetivo exercício que tivessem a idade mínima de 19 anos no ato da inscrição, grau de escolaridade entre $4^{\mathrm{a}}$ e $8^{\mathrm{a}}$ série." (GONÇALVES, 2015, p. 131). O ingresso resultava geralmente em um "convite" realizado pelas Secretarias Estaduais e Municipais de Educação, aos professores rurais não habilitados.

Por ser tratar de um curso a distância, (com um sistema modular) a dinâmica de estudos do cursista era individual, de acordo com o CETEB (1984) o currículo do projeto era composto por 208 módulos divididos em 28 disciplinas correspondendo há 4.000 horas de estudo. "Sua metodologia se fundamenta no princípio da instrução personalizada com avaliação no processo e apresenta característica de treinar professores no próprio exercício de sua profissão." (PARECER No. 0001/CEE/RO/83, p. 01).

A partir do excerto acima o professorado rural deveria deslocar-se ao núcleo urbano Centro de Estudos Supletivo (CESA) para retirada de módulos, participar de aula de microensino, e realizar as avaliaçóes. Esse traçado era uma das maiores dificuldades enfrentadas pelos docentes do meio rural, tendo de se deslocar até $30 \mathrm{~km}$ para chegar ao núcleo urbano, além das dificuldades de locomoção, recursos financeiros e logísticos (para chegar ao polo do curso), sendo estes fatores decisivos para o sucesso ou insucesso, permanecia ou evasão do cursista. 
Com a Instrução Normativa no 001 de 17 de abril de 1985, da Divisão de Ensino Supletivo de Rondônia, as novas exigências para matriculas no Logos II a partir de 1985 era bem restritas, segundo o item 3 " "Fica Vedada a matricula no Projeto Logos II, o candidato residente nas áreas urbanas, onde funcionam cursos regulares de formação de magistério." (INSTRUÇÃO No. 001/DESU/SEDUC/85, p. 01).

Destacamos que o Projeto Logos II destinava-se exclusivamente às localidades que não possuíam cursos de formação do magistério, tanto na área urbana quando na área rural, entretanto, o que predominava na época eram docentes da área rural, assim, professoras urbanas e rurais, participaram do curso, até para que em conformidade com as Diretrizes e Bases de 1971, para que os professores pudessem lecionar no ensino de primeiro grau $\left(1^{\mathrm{a}}\right.$ a $4^{\mathrm{a}}$ séries), eles deveriam ser habilitados no segundo grau, não especificando rural nem urbano.

A portaria no 1000 de 8 de julho de 1993 elaborada pela Secretária de Estado da Educação no uso de suas atribuiçóes legais no Art. $1^{\text {o }}$ descreve que o Projeto Logos II iria ser extinto a partir de 31 de janeiro de 1994, podendo dar continuidade no curso apenas os cursistas matriculados até 31 dezembro de 1992, proibindo assim o ingresso de outros cursistas a partir desta data (PORTARIA No. 1000GAB/SEDUC/93, p. 01).

Nos 14 anos de exclusão do Projeto logos II, no Brasil, matricularam-se mais de 120.000 professores leigos. Destes, cerca de 41,6\% cursistas evadiramse e não concluíram a formação e aproximadamente 70.000 receberam certificados de habilitaçáo para o exercerem o magistério de segundo grau (CETEB, 1984, p. 62).

As consideraçóes feitas até aqui demostram que o Estado se preocupa não só em qualificar permanentemente a mão de obra para o mercado capitalista, mas também em instituir políticas e programas sociais para manter sob seu controle grandes parcelas da população ainda não inseridas no processo de produção.

Assim, existe a legitimidade e o pretexto do abandono do magistério rural, uma vez que o Projeto Logos em execução há 14 anos buscava a formação (profissionalizaçáo) de todos os docentes, entretanto deixou à margem da formação ofertada significativo percentual de educadores na época.

A solução do governo do estado com parceria com os municípios foi de implantar um novo projeto de formaçáo para estes docentes leigos. Com efeito, criou o Projeto Fênix em 1996 para que pudesse dar continuidade à política de formação de professores leigos em Rondônia. 


\section{Considerações finais}

Os resultados preliminares deste estudo demostraram que os mecanismos produtores de conhecimento sobre a formaçáo do magistério rural em Rondônia surgiram no início do século XX com a Escola Normal Rural Nossa Senhora Auxiliadora e o Instituto Nossa Senhora do Calvário, ambos ofertando Curso Normal Rural.

Com o presente artigo, compreendemos que a verdadeira história não está expressava apenas nos modelos da urbanização, mas também de como o meio rural foi explorado em uma perspectiva de ver o rurícola integralizado com o seu meio. Dessa forma, nosso olhar não se volta somente para o meio rural, mas também para o meio urbano tentando compreender as duas facetas ali engendradas e como elas se articulam aos interesses políticos.

É cabível observar que, o que buscamos não é uma pesquisa positiva, nem táo pouco repetir os fatos já ocorridos, mas inaugurar a história como sendo um problema, disseminando um novo conhecimento para compreender o presente e vice-versa.

Destacamos que a oferta de curso de formação docente mais significativa voltada para o meio rural, em Rondônia deu-se na década de 1980 com o Projeto Logos II formando boa parte do magistério rural leigo rondoniense, um projeto para habilitar de forma aligeirada, professores leigos nas unidades federativas do Brasil, ofertado em dois projetos: o Projeto Logos I que, em seguida, expandiu-se para o Projeto Logos II.

\section{Referências}

ARAÚJO, Fátima Maria Leitão. Educação rural e formação de professores no Brasil: gênese de uma experiência pioneira. Cadernos de História da Educaçáo. v. 10, n. 2 - jul./dez. 2011. Disponível em: https://goo.gl/3ziRPR. Acesso em: 06 de março 2018.

BARROS, Josemir Almeida; PACIFICO, Juracy Machado. Infâncias e a escola rural: traçados e bordados. Revista de Educaçáo Pública, Cuiabá, v. 27, n. 65/1, p. 385-404, mai./ago. 2018. Disponível em: http://www. periodicoscientificos.ufmt.br/ojs/index.php/educacaopublica/article/ view/6587. Acesso em: 02 de maio 2018.

BLOCH, Mach Léopold Benjamin. Apologia da história, ou o ofício de historiador. Rio de Janeiro: Zahar, 2001.

BOTTOMORE, Tom (org.). Dicionário do pensamento marxista. Rio de Janeiro: Jorge Zahar, 1988. 
DUARTE, Sérgio Guerra. Dicionário brasileiro de educaçáo. Rio de Janeiro: Nobel, 1986.

GONÇALVES, Marli Clementino. "Eu era professora, era catequista, era enfermeira, eu era tudo!": a profissáo docente no meio rural piauiense (19711989). 2015. 198f. Tese (Doutorado) - Universidade Federal do Piauí, 2015.

LE GOFF, Jacques. A história nova. 3. ed. São Paulo: Martins Fontes, 1995.

LEITE, Sérgio Celani. Escola rural urbanização e políticas educacionais. São Paulo: Cortez, 1999.

LIMA, Abnael Machado de. Achegas para História da Educação no estado de Rondônia. 2 ed. Porto Velho: SEDUC, 1993.

LIMA, Roger dos Santos. Se eu nascesse de novo quarenta e duas vezes eu seria professor nas quarenta e duas vidas: o fazer-se professor e professora rural em fins do século XX, em Ariquemes, Rondônia. 2019. 123 f. Dissertação (Mestrado) - Curso de Pós-Graduação em Educação, Universidade Federal de Rondônia Unir, Porto Velho, 2019.

PIACENTINE, Ana Paula Fernandes da Silva. História da formaçáo para professores leigos rurais: o curso de magistério rural em Dourados, na década de 1970. 2012. 93 f. Dissertação (Mestrado em Educação) - Programa de Pós-Graduação em Educação, Universidade Federal da Grande Dourados, Dourados, 2012.

PRADO, Fernanda Batista do. Entre o oratório e a profissão: formação de professoras na Escola Normal Rural Nossa Senhora Auxiliadora em Porto Velho/ RO (1939-1946). 2017. 156 f. Dissertação (Mestrado) - Programa de PósGraduação em Educação, Universidade Federal do Mato Grosso, Cuiabá, 2017.

SECCHI, Leonardo. Politicas públicas: conceitos, esquemas de análise, casos práticos. São Paulo: Cengage Learning, 2012.

SOUZA, Cleicinéia Oliveira de. Entre o evangelho e o ensino rural: educação feminina no Instituto Nossa Senhora do Calvário (Vale do Guaporé/GuajaráMirim/MT/RO 1933-1976). 2017. 164 f. Dissertação (Mestrado) - Programa de Pós-Graduação em Educação, Universidade Federal de Mato Grosso, Cuiabá, 2017.

TEIXEIRA, Marco Antônio. Domingues; FONSECA, Dante Ribeiro da. História Regional (Rondônia). 2. ed. Porto Velho: Rondoniana, 2001.

WERLE, Flávia Obino Corrêa. Escola Normal Rural: espaço de formação de grupos dirigentes. Olhar de professor, Ponta Grossa, v. 15, n. 1, p. 33-39, 2012. Disponível em: https:/goo.gl/j9PcdV. Acesso em: 29 junho 2018. 


\section{Fontes}

BRASIL. Lei 4.024, de 20 de dezembro de 1961. Fixa as Diretrizes e Bases da Educação Nacional. Brasília: DF. 1961. Disponível em: https://goo.gl/ C76LNj. Acesso em: 25 de junho 2018.

BRASIL. Lei 5.692, de 11 de agosto de 1971. Fixa Diretrizes e Bases para o ensino de $1^{\mathrm{o}}$ e $2^{\mathrm{o}}$ graus, e dá outras providências. Brasília, DF: 1971. Disponível em: https://goo.gl/7UxpjF. Acesso em: 15 de junho 2018.

BRASIL. Projeto Logos I: avaliação. Brasília, DDD, 1975.

CETEB. Logos II: Registro de uma experiência. Brasília: Centro de Ensino Tecnológico de Brasília - CETEB, 1984.

INSTRUÇÃO No 001/DESU/SEDUC/85. Divisão de Ensino Supletivo. Redator: Cons. Abnael Machado de lima. Porto Velho, 17 de abril de 1985.

PARECER N. ${ }^{\circ}$ 0001/CEE/RO/83. Emenda: Projeto Logos II - 83. Câmera de Planejamento. Redator: Cons. Magna França de Queiroz. Porto Velho, 09 de fevereiro de 1983.

PORTARIA, N. ${ }^{o}$ 1000/GAB/SEDUC/93. Secretária de Estado da Educaçáo. Redator: Cons. (Maria Antonieta dos Santos). Porto Velho, 08 de julho de 1993.

RESOLUÇÃO N.o 00002/CEE/RO/83. Conselho Estadual de Educação. Redator: Cons. Álvaro Lustosa Pires. Porto Velho, 17 de fevereiro de 1983.

RONDÔNIA, Decreto no 426 de 04 de novembro de 1964. Cria em Porto Velho, o Centro de Treinamento de Professores Rurais de Rondônia. Governo do Território Federal de Rondônia. 1964.

RONDÔNIA. Serviço de supervisão. Território Federal de Rondônia: Secretária de Educação e Cultura. Porto Velho, 1977.

SEC expande projeto logos II. O Parceleiro. Ariquemes, 07 jul. 1979. 


\section{EDUCAÇÃO DAS MULHERES MATO-GROSSENSES: "TRABALHOS DE AGULHAS E DE PRENDAS DOMÉSTICAS NAS ESCOLAS DO SEXO FEMININO..."}

Sandra Jung de Mattos

\section{Introdução}

Neste trabalho, almejamos expor a inserção das mulheres nos espaços escolares no estado de Mato Grosso no início da República. Abordamos a Educação Feminina mato-grossense, uma vez que esta análise compóe parte da dissertaçáo de Mestrado (MATTOS, 2018) ${ }^{1}$, encerrada em 2018, que trouxe como temática a Educação Feminina mato-grossense nos primeiros anos da República, 1889 a 1910, período no qual se deram as principais reformas da Instrução Pública educacional do país.

Estabelecemos como categorias de análises: Leis e Regulamentos da Instruçáo Pública; Organização da Instrução Primária; Normas e Regulamentos para a Escolarização Feminina. E procuramos responder: como se deu o processo de inserção das mulheres nos espaços escolares em Mato Grosso nos primeiros anos da República?

Comprovamos a relevância do estudo, pois nos permitiu evidenciar a inserção das mulheres nos espaços escolares, no período de 1889 a 1910 . Verificamos que poucos são os estudos realizados a respeito e pensamos que podemos contribuir para a abertura de novas frentes de pesquisas, pois a temática amplia-se continuamente

Em 1889 se estabeleceu no Brasil o início da República. Foi um fato histórico que trouxe mudanças no país, tanto no âmbito econômico, político e social. A República tinha como alicerce a educação direcionada para inclusão de todos, uma educação voltada para o povo, base para o progresso e desenvolvimento do país. As reformas educacionais que foram estabelecidas no início da República sempre estiveram vinculadas aos interesses políticos e ideológicos que imperavam no Brasil no período. Portanto, incumbia-se aos

1 A dissertação foi defendida em 2018, sob orientação da Profa. Dra. Nilce Vieira Campos Ferreira e pode ser consultada em https:/www1.ufmt.br/ufmt/un/secao/13539/cmvmt 
governantes a elaboração de novas propostas educativas que se diferenciassem das que foram implantadas no Império.

O ideal republicano voltava-se para uma educação popular e as reformas da Instrução Pública de democratizaçáo do acesso a escolarização procuraram estabelecer e levar o povo a aceitar o novo regime, as instituiçóes educativas tinham o dever de propagar os ideais republicanos e modernizar a sociedade brasileira.

A educação das mulheres no Brasil no fim do Império e no princípio da República encontrava-se sob um viés de abandono. Escolas femininas eram quase inexistentes. A educação feminina, quando havia, ocorria com uma finalidade específica e diferenciada de uma escola para o sexo masculino. Com isso a escolarização do povo no Brasil ocorria em espaços e com conteúdo diversificados para homens e mulheres.

Nesse contexto, a inserção das mulheres nos espaços escolares e do trabalho representava uma condição de acesso à dignidade, reconhecimento pessoal e profissional, pois, propiciaria às mulheres os meios de subsistência e contribuiria para a inserção e emancipação das mulheres nos espaços públicos, mesmo que este espaço tivesse a configuração da extensão do lar e que a maioria dos cargos fossem exercidos pelos homens.

\section{A escolarização das mulheres mato-grossenses}

A Constituição da República de 1891, no artigo 35을 nos itens $3^{\circ}$ e $4^{\circ}$, constituiu a descentralização do ensino no Brasil, logo nos primeiros anos da República. O ensino secundário e superior seria criado, organizado e provido pela Uniáo nos Estados e no Distrito Federal, enquanto que prover e legislar o ensino primário era de competência dos estados. (BRASIL, 1891).

Para Otaiza Oliveira Romanelli (1986), a Constituição da República de 1891 gerou um sistema de ensino no qual a União seria responsável pela Instrução Superior em toda a nação, assim como pelo ensino secundário e pela instrução em todos os níveis no Distrito Federal. Os estados proveriam e normatizariam o ensino primário e o ensino profissional, que na época, compreendia as escolas técnicas profissionais para rapazes e escolas normais, de nível médio, para as moças.

Maria Benicio Rodrigues (2009, p. 18) relatou que a educação "entendida como um instrumento eficiente de desenvolvimento intelectual e moral do povo", desempenharia um papel primordial com forte atuação na cultura, na formação da sociedade e no desenvolvimento da nação, considerada a base do progresso do povo brasileiro. 
Nesse contexto, a inserção das mulheres nos espaços escolares representava uma condição de acesso à dignidade, reconhecimento pessoal e profissional, pois, propiciaria às mulheres os meios de subsistência, livrando-as de uma "dependência humilhante para elas", "nefasta para os homens", e contribuiria para o "amadurecimento da personalidade feminina, ajudando a "disciplinar a vontade e educar o pensamento". A escolarização oportunizou às mulheres uma posição de divergência e de "luta" frente a uma sociedade historicamente masculinizada, ou seja, a educação foi "essencial para a emancipação das mulheres". (SOIHET, 2013, p. 220-221).

O Regulamento do Ensino Primário da Província de Mato Grosso de 1889 formulado por Souza Bandeira, na reforma da instrução primária propôs que as escolas continuassem públicas, gratuitas e com ensino obrigatório, muito embora não tenha previsto como poderia atender a todas as crianças. Em todas as localidades, fossem vilas, povoados ou cidades teriam escolas conforme a necessidade para inclusão de todas as crianças, "haverá para cada sexo tantas quantas forem necessárias". Para cada escola masculina deveria ter também uma escola feminina. (LEITE, 1971, p. 80).

Uma das mudanças na Instrução Pública promovida por Souza Bandeira em 1889 foi a de confiar às mulheres a regência das escolas primárias ao estipular que as mulheres deveriam ser selecionadas para a regência das escolas femininas e masculinas. (MATO GROSSO, 1889, p. 1). No mesmo Regulamento foi instituído o Externato do Sexo Feminino junto com o Liceu Cuiabano que seria a instituição exclusiva e responsável pela formação, preparação e qualificação de professoras para a regência das escolas primárias.

Humberto Marcílio (1963), descreveu o discurso de Antônio Herculano de Souza Bandeira sobre a implantação do Externato do Sexo Feminino.

De modo modesto e despretensioso, com organização acomodada aos recursos financeiros da Provincia, pretendi fundar uma escola especial, onde as jovens mato-grossenses, possam ampliar a esfera dos seus conhecimentos, com as liçóes dos melhores mestres da Provincia e ao mesmo passo se habilitarem para o magistério das escolas públicas. Está lançado o primeiro fundamento de uma instituição que prestará relevantíssimos serviços se na difícil jornada as urzes 
do caminho não amendrontarem os iniciadores e não amortecerem-lhes o zelo. Confio na dedicação do pessoal escolhido, e dele espero que se revelará digno da sua honrosa incumbência. Resta-nos fazer votos para os espíritos patrióticos tomem sob sua proteção o utilíssimo instituto. (MARCÍLIO, 1963, p. 102-103).

Para Humberto Marcílio (1963), a criação do Externato do Sexo Feminino era um estimulo para que a mulher exercesse a profissão de professora, uma vez que os baixos salários não era motivação para os professores homens permanecerem na profissão, ao contrário da mulher que tinha aptidão natural para o oficio.

Com mais professoras sendo formadas, o espaço do ensino primário seria ocupado majoritariamente por professoras normalistas mulheres. Marcílio (1963) ainda descreveu que no Externato Feminino os "dotes" naturais da mulher para o magistério seriam ressaltados, pois a mulher seria a pessoa ideal para desempenhar a "penosa” profissão de professora. A escola primária, portanto, deveria ser a continuidade da família, bem como, do lar doméstico.

A mulher mais prendada afeiçoa o espírito e o coração dos seus ternos filhos com aquelle segredo que os pais mais ilustrados não praticam, nem compreendem, assim também na escola elementar, destinada a auxiliar e aperfeiçoar o trabalho da família, vem a ser uma inconsequência abandonar ao homem aquela tarefa. (MARCÍlIO, 1963, p. 102).

A mulher, no desempenho das funções do magistério da educação primária, teve a oportunidade de conquista do espaço público, mesmo que este lugar tivesse a configuração da extensão do lar e que a maioria dos cargos diretivos fossem exercidos pelos homens. (MATTOS, 2018).

Louro (1987) ressaltou essas transformaçóes da sociedade brasileira em relação as práticas educativas bem como as oportunidades de acesso das mulheres ao trabalho nas escolas, mas que essas transformaçóes não aconteceram "numa escalada ascensional”, pelo contrário, é marcada por avanços e retrocessos. As escolas como foram concebidas reforçara a divisão de papéis conforme a imposição histórica da sociedade.

A atuação no magistério foi o caminho encontrado pelas mulheres para a inserção nos espaços públicos de trabalho. Aos poucos as mulheres "rasgam o véu" e adentraram os espaços das instituiçóes escolares, seja ela como aluna ou como professora, regente de classe, responsável pelas primeiras letras dos meninos e meninas confiados a ela. 
O destino das mulheres ainda é, sem dúvida, a maternidade e o lar; a esfera de atuaçăo feminina é a doméstica. Mas começa-se a admitir mais amplamente a atividade profissional fora do lar para as que 'precisavam' trabalhar e nesta atividade ganha realce o magistério primário. (LOURO, 1987, p, 15).

Em Mato Grosso, no ano de 1889 funcionaram 32 escolas públicas, 12 escolas para o sexo feminino, inclusive as destinadas ao ensino misto. O programa de disciplinas eram: Leitura, Escrita, Catecismo da Doutrina Cristá, Gramática portuguesa e composição, Elementos de Aritmética, compreendendo a sistema legal de pesos e medidas, Noçóes gerais de geografia, com maior desenvolvimento a respeito do Brasil, Noçóes de história do Brasil e Trabalhos de agulha e de prendas domésticas nas escolas do sexo feminino. (MATO GROSSO, 1889).

Percebemos que eram poucas as escolas femininas e que no programa de disciplinas se incluíam conteúdo específicos para as escolas do sexo feminino.

No Regulamento da Instrução Pública de 1891, que promoveu nova reforma do ensino primário, promulgada pelo presidente do Estado de Mato Grosso Manoel José Murtinho, não trouxe nenhuma mudança quanto ao programa para as escolas primárias femininas que continuaram incluindo entre as disciplinas os afazeres manuais ou "trabalhos de agulhas e de prendas domésticas, nas escolas do sexo feminino”. (MATO GROSSO, 1891, p, 7).

As escolas femininas destinadas a educação de meninas tinham suas características específicas desde as disciplinas que lhes eram ministradas até nos espaços que frequentavam. Moças e meninas eram educadas na modalidade de "como ser e agir". A elas era imposto um modo de vida "em sua materialidade, um sistema de valores, como ordem, disciplina e vigilância”. (LOURO, 2015, p. 455).

A Reforma de Souza Bandeira trouxe inovação para o ensino primário da Província em 1889. Também o Regulamento da Instrução Pública de 1891 do Presidente Manoel José Murtinho, pois ambos estabeleciam uma educação para as mulheres um pouco mais ampliada, mantendo um estreito controle sobre o ensino a ser oferecido, relacionado aos afazeres domésticos, como costurar e bordar, trabalhos de agulhas e de prendas domésticas. As mulheres poderiam frequentar a escola, mas sem esquecer o espaço do lar, das tarefas da casa.

No Regulamento da Instrução Pública de 1891, constava que nas escolas de educação feminina vigoravam a separação dos sexos e a aplicação de disciplinas específicas. Vemos uma aproximação dos sexos com as escolas mistas, mas 
no Estado mato-grossense as meninas e meninos nas escolas mistas eram separados por período, segregado pelo espaço e tempo.

Artigo $35^{\circ}$ - Em todas as escolas primárias os exercícios diários se verificarão em duas sessōes: uma das 7 às 10 horas da manhã, e outra de 1 às 4 horas da tarde. $\$$ Único: Nas escolas mistas a sessão da manhã será destinada às meninas, e a da tarde aos alunos do sexo masculino. (MATO GROSSO, 1891, p. 7).

Com a autorização do Diretor Geral seriam admitidas crianças de outros sexos, de 6 a 10 anos, desde que ficassem separadas, meninos e meninas cada um nos espaços conferidos separadamente, com admissão de no máximo 100 alunos frequentes em cada escola.

Artigo $32^{\circ}-$ Em todas as escolas do sexo feminino poderão ser admitidas crianças de outro sexo, de 6 a 10 anos de idade, mediante prévia autorização do Diretor Geral, sendo acomodadas de modo que fiquem completamente separadas pelo sexo. Artigo $33^{\circ}$ - $\mathrm{O}$ número máximo de alunos frequentes, que poderá admitir uma escola, é o de cem. (MATO GROSSO, 1891, p. 7).

A distribuição dos alunos por sexo nas escolas primárias comprova a diferenciação de ensinamentos que eram ofertadas às meninas, uma vez que o conteúdo era diferenciado e incluía temas que as levassem a ser educadas para a atuação na esfera doméstica. No Artigo $35^{\circ}$ do Decreto $n^{\circ} 10$ de 7 de novembro de 1891, o parágrafo único reforçou a distinção ao determinar a separação das salas de aula para os sexos feminino e masculino. "Nas escolas mistas a sessão da manhã será destinada às meninas, e a da tarde aos alunos do sexo masculino. (MATO GROSSO, 1891, p. 7).

Meninas e moças poderiam frequentar "escolas de primeiras letras, as pedagogias, em classes separadas dos meninos e lecionadas por professoras mulheres "as quais deveriam ser comprovadamente honestas e dignas". (LOURO, 1987, 25).

No Decreto $\mathrm{n}^{\circ} 68$ de 20 de junho de 1896, que regulamentou a Instrução Primária, nas modalidades elementares e complementares, continuou mantendo a separação de meninos e meninas. As escolas eram para ambos os sexos, mas destacou que as escolas elementares femininas seriam prioritariamente regidas por professoras, por senhoras honestas e de boa índole, pois seriam responsáveis pela educação vinculada à modernização da sociedade e a construção da cidadania dos jovens. (LOURO, 1987). 


\section{Para os homens o ensino das ciências e para as mulheres os afazeres do lar}

A educação para homens e mulheres ocorria de forma diferenciada. Para os homens era ensinado as ciências, a Geometria e para as mulheres, o ensino dos afazeres do lar, perpetuando o que tradicionalmente era imposto pela sociedade paternalista conservadora.

Aqui e ali, no entanto, havia escolas - certamente em maior número para meninos, mas também para meninas; escolas fundadas por congregaçóes e ordens religiosas femininas ou masculinas; escolas mantidas por leigos professores para as classes de meninos e professoras para as de meninas. Deveriam ser, eles e elas, pessoas de moral inatacável; suas casas ambientes decentes e saudáveis, uma vez que as famílias lhes confiavam seus filhos e filhas. As tarefas desses mestres e mestras não eram, contudo, exatamente as mesmas. Ler, escrever e contar, saber as quatro operaçóes, mais a doutrina cristá, nisso consistiam os primeiros ensinamentos para ambos os sexos; mas logo algumas distinçôes apareciam: para os meninos, noções de geometria; para as meninas, bordado e costura. (LOURO, 2015, p. 444).

Lembramos, como dito por Guacira Lopes Louro (1987), que a educação da mulher "envolvia doutrinação da mulher sobre seu lugar na sociedade; ou seja, algumas informaçóes lhe eram permitidas, é claro, mas envolvidas pelas funçôes e papéis a ela recomendados". A educação feminina estava voltada, portanto, para educar para a missão maternal da mulher que seria responsável pela formação dos futuros homens, isto é, "a finalidade da educação da mulher não estava, portanto, nela mesma, mas fora dela, na sua extensão, que são seus filhos”. (LOURO, 1987, p. 26).

As concepçóes da educação feminina eram permeadas por elementos que perpetuavam as diferenças e divisóes de relaçóes entre o masculino e o feminino que eram reafirmados pela sociedade da época.

As concepçôes e formas de educação das mulheres nessa sociedade eram múltiplas. Contemporâneas e conterrâneas, elas estabeleciam relaçôes que poderiam revelar e instituir hierarquias e proximidades, cumplicidades ou ambiguidades. Sob diferentes concepçóes, um discurso ganhava hegemonia e parecia aplicar-se, de alguma forma, a muitos grupos sociais a afirmação de que as mulheres deveriam ser mais educadas 
do que instruídas, ou seja, para elas, a ênfase deveria recair sobre a formação moral, sobre a constituição do caráter, sendo suficientes, provavelmente, doses pequenas ou doses menores de instrução. $\mathrm{Na}$ opiniáo de muitos, não havia porque mobiliar a cabeça da mulher com informaçôes ou conhecimentos, já que seu destino primordial - como esposa e mãe - exigiria, acima de tudo, uma moral sólida e bons princípios. Ela precisaria ser, em primeiro lugar, a mãe virtuosa, o pilar de sustentaçáo do lar, a educadora de geraçóes do futuro. (LOURO, 2015, p. 446).

A mulher deveria receber uma educação moral, ou uma formação de boa índole, formar uma boa administradora do lar, assim se faria uma nação forte, como nas palavras de José Veríssimo (1985, p. 125): "queremos melhorar, favorecendo intencionalmente a evoluçáo brasileira, de modo a dar um dia ao nosso País uma posição proeminente no mundo, cumpre-nos começar por melhorar o principal órgáo de educação de uma sociedade, que é, evidentemente, a mulher".

Havia, portanto, uma intencionalidade na educaçáo da mulher para o desenvolvimento do estado brasileiro e Mato Grosso compunha o processo. Às mulheres no ensino básico como aluna e a formação como professora com diretrizes específicas e campo de atuação profissional determinado. No processo educativo cabia um "mestre exemplar", responsável pela conduta de cada criança, para que as condutas ensinadas e aprendidas no espaço escolar pudessem perpassar os espaços extraescolares. (LOURO, 2014).

As meninas que frequentavam as escolas femininas, passavam um longo tempo, como evidenciado por Louro (2014, p. 66), dedicando-se "intensas e repetidas horas ao treino das habilidades manuais de suas alunas produzindo jovens "prendadas", capazes dos mais delicados e complexos trabalhos de agulha ou de pintura". Poucas eram as mulheres que ascendiam para outros espaços, como o ensino secundário e o ensino superior.

Mato Grosso, como outros estados brasileiros, passava por momentos de transformação da educação, estabelecendo nova configuração na Instrução Pública para a formaçáo de mulheres. Mas pouco efetivamente se fez no período em estudo para a educação das mulheres, e quando se fez, pregava-se uma educaçáo e submissáo feminina aos preceitos patriarcalistas, subestimando a inteligência feminina e quase sempre condicionando o ensino e a aprendizagem das mulheres a uma forte vinculação com a responsabilidade pela família e pelo ambiente doméstico, afinal cabia a elas educar a infância. 


\section{Escolarização das mulheres: entre o espaço público e privado}

Em Mato Grosso, a educação das mulheres era uma resposta às demandas dos ideais republicanos para o Brasil, da inclusão de todos na escola, de "universalizar a escolaridade", do poder e da responsabilidade atribuídos às mulheres, levava para uma educação designada para preparar a mulher para atuar nos espaços domésticos, no cuidado da família, não para exercício de uma profissão. Ao "ser educada" a mulher começou a ganhar espaços e se inseriu no ambiente profissional, principalmente atuando no magistério e, mesmo sendo formada para a missáo imposta de ser uma "companhia mais agradável para o homem”. (ALMEIDA, 2004, p. 71).

O Regulamento da Instrução Pública de 1891 estipulou condiçóes para o ingresso no magistério. Aquelas que desejassem atuar nas salas de aula deveriam submeter-se a três provas. A primeira prova era escrita e deveria conter uma questão teórica de pedagogia ou de algum assunto referente à História ou Geografia do Brasil. A prova deveria ser realizada em duas horas. A segunda prova era a arguição, durando apenas meia hora, sobre conteúdo do programa das escolas primárias, uma questão para cada disciplina a ser ministrada. A terceira prova era prática, na qual era preciso ministrar, em trinta minutos, uma aula em uma escola primária.

Para as mulheres inscritas, candidatas do concurso, haveria uma prova referente às habilidades de prendas domésticas e os trabalhos com agulhas. A mulher que seria professora deveria conhecer os ofícios e afazeres do lar.

O Artigo $56^{\circ}$ - Nos concursos para provimento de escolas do sexo feminino, ou de escolas de $1^{\text {a }}$ classe, a comissão examinadora ouvirá pessoa competente sobre a habilitaçôes das candidatas em trabalhos de agulha e prendas domésticas. (MATO GROSSO, 1891, p. 8).

Ao submeter as candidatas professoras à prova final de habilidade de trabalhos com agulhas e prendas domésticas esperava-se que elas ensinassem às futuras alunas aquilo que elas continuariam a desempenhar no espaço do lar, as "prendas domésticas", nesse sentido revela-se que a "mentalidade vigente sobre as expectativas sociais quanto ao sexo feminino continuavam atreladas às fronteiras do universo doméstico". (ALMEIDA, 2014, p. 116). Os conteúdos e os ensinamentos deveriam ser comuns a todas e todos, mas eram ministrados de formas diferentes para meninas e meninos. 
É preciso, pois, educar as meninas, e não exatamente instruílas. Ou instruí-las apenas no que é necessário para torná-las agradáveis e úteis: um saber social em suma. Formá-la para seus papéis futuros de mulher, de dona de casa, de esposa e mãe. Inculcar-lhes bons hábitos de economia e de higiene, os valores morais de pudor, obediência, polidez, renúncia, sacrifício $[\ldots]$ que tecem a coroa das virtudes femininas. (PERROT, 2015, p. 93).

Nessa perspectiva, as habilidades de trabalhos de agulhas e prendas domésticas cobradas das candidatas à professora, remetia para os pressupostos necessários à educação feminina. Portanto, os espaços escolares seriam espaços de perpetuação das condutas domésticas femininas. A educação munia-se de princípios morais e de condutas de submissão ao homem.

Para Louro (1987), mesmo com as condiçóes que eram impostas à escolarização das mulheres, frequentar as escolas representava a oportunidade de acesso aos estudos e a possibilidade de exercer uma profissão, de adentrar os espaços públicos, ainda que fosse sob a doutrinação e autoridade masculina.

De um lado, essas determinações representam não só a oportunidade de estudo para as meninas, mas também um espaço profissional para as mulheres (como professoras), o que é um avanço; mas de outro lado, os liceus, ginásios e academias ainda ficavam restritos aos rapazes, e supunha-se que o currículo das classes femininas deveria ser diferente (reduzido em alguns aspectos, inclusive) do dos meninos do mesmo nível. Note-se ainda que uma das diferenças no currículo era à geometria, considerada desnecessária para as meninas (bastava que estas soubessem as quatro operaçôes, e justamente geometria servia para distinguir dois níveis de salário para os professores; entáo, deste modo, ainda que por lei os salários devessem ser idênticos, os que lecionavam geometria (portanto, só os professores homens) receberiam maior pagamento. (LOURO, 1987, p. 25).

Em relação aos currículos e conteúdos, o que ditava e caracterizava o ensino era o modelo social vigente de uma forma de ser do rapaz e da moça. Para as moças, a educação deveria seguir um padrão de mulher "idealizado pelo discurso republicano, que seria o de uma educadora dos filhos e formadora dos futuros cidadãos, além de se pretender um traquejo social e a boa representatividade da mulher junto ao esposo". (PINHEIRO, 2009, p. 28).

Buscava-se estabelecer e operacionalizar uma nova política educacional republicana para diferenciar da educação oferecida no Império, mas o ensino diferenciado oferecido para meninas e meninos refletia a continuidade na qual 
o "lugar de mulher é em casa, como mãe, esposa, dona de casa", de tal forma que as regulamentaçóes e reformas propostas podem ser compreendidas como "um momento da atuação dos reformadores da educação em defesa de uma situação já criada”. (FARIA FILHO, 2000, p. 109).

A esse respeito, Louro (1987) descreveu que a escola brasileira reforçou os papeis femininos tradicionais por meio de regulamentos e normas estabelecidos, consagrando a desigualdade entre os sexos, na qual a escola pode ser considerada como uma grande influência, uma vez que interiorizou e disseminou a aconcepcao de um "perfil feminino submisso e obediente". (LOURO, 1987, p. 12).

Também as regulamentaçóes promovidas em Mato Grosso no período colocavam em vigor uma educação feminina que deveria voltar-se para os ensinamentos do lar, uma formação para a mulher que a levasse a ser uma "boa" senhora do lar, com amplo "domínio da casa”, enfim, no destino de ser esposa e mãe com uma "moral sólida e bons princípios", conforme a intencionalidade do programa de ensino do regulamento, como em vários momentos apontado por Louro (1987; 2015) e Almeida (1998).

Podemos analisar que a conquista do espaço público para as mulheres deu-se com a entrada no ensino primário, como aluna e/ou como professora, pois oportunizou às mulheres adquirir formação específica e atuar no processo educacional, ainda que atrelado à formação e sina de ser mãe e educadora. Ainda assim, o fato de poderem estudar e se profissionalizar implicou a conquista de espaço, liberdade e autonomia frente à sociedade em transformação.

A entrada das mulheres na escola conferiu-lhes uma posição privilegiada, de espaço, conhecimento e saber do qual historicamente estavam excluídas. Com isso, mulheres romperam as normas e desafiaram modelos e paradigmas para saírem do espaço do lar e exercerem uma profissão. Entre os trabalhos de agulha e as prendas domésticas, as mulheres definiram seus caminhos ao incorporar novas aspiraçóes, a busca de espaço próprio nos quais pudessem se aperfeiçoar. Ao frequentarem as escolas normais, preparam-se, sob olhares hostis de homens, e se reconheceram como mulheres que tinham o dever de "transformar uma nação, apesar das notórias dificuldades enfrentadas por elas, como mulheres e como profissionais". (ALMEIDA, 1998, p. 26).

Parece-nos assim que instruir as mulheres, na concepção da época, representaria um risco para a sociedade, isto por que as atividades fora de suas moradas habituais poderia "ameaçá-las como mulheres, por isso o trabalho deveria ser exercido de modo a não as afastar da vida familiar, dos deveres domésticos, da alegria da maternidade, da pureza do lar". (LOURO, 2015, p. 453). 
Prevalecia o discurso da existência "de duas espécies, com qualidades e aptidóes particulares. Aos homens, o cérebro, a inteligência, a razão lúcida, a capacidade de decisão. Às mulheres, o coração, a sensibilidade, os sentimentos". (PERROT, 2006, p. 177). Desse modo, justificava-se a razão da divisão das funções e da instrução da mulher ser voltada para os afazeres domésticos e a manutenção da família.

Para Veríssimo (1985) a educação feminina atrelada ao magistério serviria para tirar a visão do atraso, provinda do colonialismo. A mulher seria a mais indicada, náo somente para educar filhas e filhos, mas a naçáo brasileira. A mulher brasileira deveria ser tirada da "quase ignorância" e tornar-se educadora dos homens, provedora de uma educação para tornar uma nação forte. A mulher seria responsável pelo desenvolvimento do país, para educação de homens e mulheres que pudessem transformar uma nação.

\section{Mulheres na regência de classes do ensino primário}

O Regulamento da Instruçáo Pública de 1889 determinava que as mulheres seriam responsáveis pela regência das escolas de $2^{\mathrm{a}}$ e $3^{\mathrm{a}}$ classe do sexo masculino, assim como as escolas de $1^{\text {a }}$ classe $^{2}$, como citado no Artigo $3^{\circ}$ do regulamento: "para a regência de $2^{\text {a }}$ e $3^{\text {a }}$ classe do sexo masculinos, serão preferidas as senhoras; a ellas, porém, será exclusivamente confiada as regências das escolas de $1^{\text {a }}$ classe, salvo impossibilidade absoluta". (MATO GROSSO, 1889, p. 1).

Marcílio (1963) relatou que no discurso de abertura da sessão solene do Externato Feminino, o Presidente da Província Souza Bandeira destacou que seria um prejuízo para a educaçáo excluir do ensino normal quem poderia melhor exercer a tarefa do ensino primário, além de ser incoerente deixar o homem desempenhar o papel que a mulher faria muito melhor, isto é, a mulher "melhor e mais vantajosamente pode desempenhar a árdua profissáo de mestre." (MARCÍLIO, 1963, p. 102).

O Decreto $\mathrm{n}^{\circ} 10$ de 7 de novembro de 1891 determinara que a regência das escolas de $2^{\mathrm{a}} \mathrm{e} 3^{\mathrm{a}}$ classes do sexo masculino, na capital e nas localidades que houvessem constituídas suas comarcas, deveriam ser cominadas às mulheres

2 As escolas da $1^{\text {a }}$ Classe seriam as escolas das províncias, só podendo haver uma em cada localidade com ensino para alunos de ambos os sexos. As vilas ou cidades nas quais houvessem comarcas funcionaria uma Escola de $2^{\text {a }}$ Classe, uma escola para cada sexo. As escolas da $3^{\text {a }}$ Classe funcionariam nas escolas da Capital, tendo quantas escolas fossem necessárias para ambos os sexos. (MATO GROSSO, 1889). 
em igualdade de condiçóes aos homens. Nas escolas de $1^{\text {a }}$ classe, seriam admitidas crianças de ambos os sexos, sob a regência, de preferência, de uma professora." (MATO GROSSO, 1891).

A partir dos relatórios da Instrução Pública elaborados entre os anos de 1889 a 1910, pelos diretores da Instrução Pública do Estado de Mato Grosso: Alfredo José Vieira (1889), João Pedro Gardês (1892), Joaquim Pereira Ferreira Mendes (1893, 1895), José Estêvão Corrêa (1898), Januário da Silva Rondon (1899), Estevão Antônio Corrêa (1909), José Estevão Corrêa (1911), foi possível identificar o número de homens e mulheres que atuaram no magistério primário em Mato Grosso.

Porém, mesmo tendo recorrido aos arquivos do Arquivo Público de Mato Grosso, ao acervo do Instituto Memória do Poder Legislativo de Mato Grosso e do Center for Research Libraries, não conseguimos encontrar dados referentes aos anos de 1891,1902, 1904, 1907 e 1908.

\section{Quadro 1 - Professores e Professoras do Ensino Primário mato-grossense3.}

\begin{tabular}{|c|c|c|}
\hline Ano & Homens & Mulheres \\
\hline 1889 & 17 & 23 \\
\hline 1892 & 18 & 21 \\
\hline 1893 & 18 & 23 \\
\hline 1895 & 19 & 18 \\
\hline 1898 & 24 & 21 \\
\hline 1899 & 27 & 33 \\
\hline 1909 & 37 & 28 \\
\hline 1910 & 48 & 182 \\
\hline Total & 208 & 28 \\
\hline
\end{tabular}

\section{Fonte: Elaborado pela pesquisadora.}

3 Quadro 04 elaborado pela pesquisadora a partir de dados coletados nos relatórios da Instrução Pública de Mato Grosso arquivados no Arquivo Público de Mato Grosso - APMT. 
Entre os anos de 1889 a 1909, averiguamos que homens e mulheres atuavam no exercício do magistério do ensino primário. Podemos constatar que apenas no ano de 1910 houve um aumento significativo de homens no magistério, o que nos parece justificado devido ao maior número de escolas masculinas existentes e talvez pelo início das aulas nos grupos escolares em Mato Grosso ${ }^{4}$.

No Relatório elaborado por Vieira (1889) identificamos que o número de docentes totalizou: 17 professores e 15 professoras. No relatório de Gardés de 1892, eram 18 professores e 23 professoras em atuaçáo, o que nos permite inferir que a partir da reforma realizada por Souza Bandeira (1889) as mulheres foram, em sua maioria, responsáveis pela regência de classe do ensino primário das escolas masculinas e femininas, como deliberado pelo Regulamento do Ensino Primário da Província de Matto Grosso de 1889.

Analisamos, portanto, que houve incentivo para que a regência de classes das escolas primárias fosse conduzida por professoras e que a reforma da Instrução Pública promulgada em 1889, segundo os ideais republicanos, ainda que minimamente, obteve resultado satisfatório na inclusão das mulheres para a educação das crianças, uma atuação feminina voltada para o ensino primário.

Almeida (1998, p. 23) apontou que apesar de o magistério ter "assumido contornos de maternidade e esculpir-se nos moldes da formação de boas donas de casa e mães de família”, foi a oportunidade que as mulheres tiveram para entrar na profissão, e mesmo que, ainda não fosse uma "concessão masculina, nem se veiculou sem estar impregnado de preconceitos ligados ao sexo", foi uma importante chance das mulheres ocuparem outro espaço além daquele que lhes era determinado pela "sociedade masculina e representado pela vida no lar".

Entre os anos de 1893 a 1895 , as mulheres superaram os homens no exercício do magistério, o que nos leva a afiançar que as reformas promovidas pelo Decreto $\mathrm{n}^{\circ} 10$ de 1891, de certa forma inspirado na Reforma Souza Bandeira, manteve o incentivo à presença das mulheres na regência do ensino primário. $\mathrm{Na}$ vigência do Decreto $\mathrm{n}^{\circ} 10$ de 1891 a reorganização do ensino primário, secundário e do curso normal manteve os princípios de que a mulher caberia a responsabilidade do ensino primário.

A partir de 1898 essa realidade começou a mudar e verificamos o aumento de homens na regência do ensino primário. Em 1898, eram 24 homens para

4 A reforma educacional de 1910 teve início com aprovação da Lei 517 de 4 de junho de 1909 e a Lei 533 de 4 de julho de 1910, conferindo ao governo autoridade para criar escolas quantas fossem necessárias e reorganizar a educação no estado de Mato Grosso. Os grupos escolares reuniam professores e alunos em um só prédio sob uma única direção, e se organizavam em classes seriadas, unidade de programa, horário e sequência gradual dos conteúdos. (RODRIGUES, 2009). 
18 mulheres; em 1899: 27 homens e 21 mulheres; em 1909: 37 homens e 33 mulheres; em 1910 encontramos o maior número de homens no exercício do magistério: 48 homens e 28 mulheres. Avaliamos que uma das justificativas para esse crescimento de professores atuando no ensino primário atendia ao que fora estabelecido no Decreto ${ }^{\circ} 68$ de 1896 no artigo $9^{\circ}$ que estabeleceu: "haverá escolas elementares para meninos e para meninas, sendo aquelas regidas por professores e estas por professoras". (MATO GROSSO, 1896, p. 2). A Professora continuaria na regência das classes do ensino primário nas escolas femininas. As escolas masculinas, existentes em maior número, seriam regidas exclusivamente por professores.

Confirmamos que mesmo os regulamentos determinando que a regência das salas de aulas deveria ser exercida por mulheres, apuramos que as salas de aula continuaram a ser regidas em maior número por professores homens.

Aos homens também eram atribuídos os cargos de inspeção e direção, afinal prevalecia a visão de que as mulheres eram inaptas para exercerem a profissão de professoras ou gestoras da educaçáo no estado mato-grossense, como podemos comprovar na mensagem presidencial que Manoel José Murtinho enviou para a Assembleia Legislativa do Estado de Mato Grosso, emitida em 13 de maio de 1895, na qual enfatizou seu descrédito da regulamentação da Instruçáo Pública a respeito da regência de salas de aula por professoras.

Permitir-me-eis, entretanto, plano de reformas a executar-se deve figurar uma medida que parece reclamada por diuturna observação, e talvez obedeça a influência do nosso meio social; é a de exigir que as escolas de instrucção primária para o sexo masculino sejam exclusivamente regidas por professores, visto como as senhoras, por falta do preciso preparo entre nós, bem como da indispensável energia para lidar com meninos, não têm provado bem na regência de taes cadeiras, dando lugar a que escolas publicas de semelhante classe sejam poucos frequentadas, procurando os meninos de preferencia as escolas particulares, com grave descredito do ensino oficial. (MURTINHO, 1895, p. 10).

Murtinho (1895) justificou que os homens, mais capacitados ao ensino do que as mulheres, declinavam do ensino primário, devido à "minguada" remuneração que recebiam. Desse modo, era inaceitável que homens habilitados procurassem o magistério público primário como profissão e "por isso que quase todos os candidatos às escolas públicas são senhoras, as quais pelas condições próprias do seu sexo, podem viver com menores vencimentos”. (MURTINHO, 1895, p. 11). 
Podemos afirmar, portanto, que embora as reformas instituídas a partir do Regulamento de 1889 fossem na direção de mudanças na Instrução Pública mato-grossense para o ingresso de mais mulheres na profissão do magistério a situação pouco se alterara ao longo dos anos. Mas vemos um salto significativo em 1910: o número de professores superava em mais de 50\% o número de mulheres na regência do ensino primário.

No ano de 1896, conforme mencionado no relatório da Instrução Pública apresentado no ano de 1897 pelo Diretor José Estevão Corrêa, consta que foram aprovados 27 alunos, destes 5 eram mulheres. O parco desempenho desses alunos foi creditado ao fato das mulheres exercerem a regência das escolas primárias sem o devido preparo para exercer o ensino primário que foi regulamentado pelos Decretos dos anos de 1891 e 1896.

Costa (1897, p. 21), em sua mensagem presidencial, expôs que era grave problema a regência das escolas primárias sob a responsabilidade das mulheres. Pelo fato de se confiar a elas o ensino primário, a admissão e as indulgências nos concursos nem sempre proviam "professoras idôneas". Para além disso, como as escolas não tinham sido classificadas em relação ao nível e modalidade de ensino que ofertavam, o atendimento e a diversidade de alunos com idades diferentes dificultava um ensino de qualidade. Era necessário fazer a reforma e "remediar esses inconvenientes", e, portanto, um "novo projeto de reforma do ensino primário, bem como do secundário seria necessário”.

Pedro Leite Osório (1907, p. 18) também mencionou em sua mensagem presidencial que a "experiência tem mostrado a necessidade de se acabar com a praxe de serem as escolas do sexo masculino regidas por senhoras, em vez de sê-lo por homens", considerando que os homens são mais capazes do que as mulheres para manter a disciplina em sala de aula, visto que, as mulheres por "diversas causas naturais" não exercem as funçóes de mestre com a mesma "assiduidade e dedicação" do homem, ainda mais se tiver que cumprir com a responsabilidade de manter um casamento.

Osório (1907), tal como Costa (1896), responsabilizou as mulheres pela falta de ordem e disciplina nas escolas e a necessidade de mudança no regulamento para acabar com esta prática.

Desse modo, Osório (1907) não admitia que o trabalho da mulher como professora pudesse ser eficiente. Defendemos o pensamento de que, para ele, o fim último da educação seria preparar a mulher para atuar no espaço doméstico e incumbir-se do cuidado com o marido e os filhos. A mulher educada dentro das aspiraçóes masculinas seria uma companhia mais agradável para o homem que transitava regularmente no espaço urbano, como já dito por Almeida (1998). 
Michelle Perrot (2005, p. 459) relacionou a divisão sexual dos espaços e das esferas sociais ao público e ao privado: "aos homens, o público, cujo centro é a política; às mulheres, o privado, cujo coração é formado pelo doméstico". Às mulheres, a ordem e a manutenção da sociedade tradicional e patriarcalista. Esse deveria ser o papel assumido pelas escolas ao lhes garantir escolarizaçáo: formá-las para a manutenção dos "bons costumes" e para preservar a moral e os bons costumes das famílias patriarcalistas.

A escola tratou de formar os homens para o governo e a manutenção da ordem. As funçóes das mulheres seriam o cuidado com o lar e nos espaços públicos, quando muito a atuação no magistério ou outras atividades que as levassem a criar "bem" suas filhas e filhos, de modo a formar meninas e meninos para serem boas/bons cidadãs/cidadãos. Cumprindo suas "obrigaçóes naturais" a mulher conseguiu atuar em papel de destaque na vida social.

\section{Considerações finais}

A inserção das mulheres nos espaços escolares mato-grossenses se estabeleceu de forma diferenciada e especifica da escolarização masculina. A escolarização das mulheres ocorria em espaços e com conteúdos diferenciados para homens e mulheres.

A educação das mulheres no fim do Império e no princípio da República encontrava-se enfraquecida pela falta e quase que abandonada. Escolas femininas eram quase inexistentes. A educação feminina, quando havia, ocorria com uma finalidade específica e diferenciada de uma escola para o sexo masculino. Com isso a escolarização do povo no Brasil ocorria em espaços e com conteúdo diversificados para homens e mulheres.

Ao frequentar o espaço escolar, as mulheres conquistaram progressivamente um pouco mais de liberdade que possibilitou que se reconhecessem como parte da sociedade e do processo educacional. Apesar de ser considerada como vulnerável, precisava ser educada sem deixar os espaços de educação doméstica.

Também em Mato Grosso, como outros estados brasileiros, as mulheres permaneceram privadas de escolarização similar a que era oferecida aos homens. Estudando conteúdos diferenciados e educando-se nas catequeses e escolas religiosas, às quais ensinavam, sobretudo, costura e bordado ou os "trabalhos de agulha", boas maneiras e oraçóes e o cuidado com suas famílias, uma vez formadas, voltavam-se assim ou para profissóes com os cuidados com a saúde ou para a atuação no magistério. 
As reformas educacionais e políticas Mato-grossenses, no período analisado, voltadas à escolarizaçáo das mulheres, delegavam às mulheres determinadas atitudes e açóes que perpassavam os espaços educativos de formaçáo feminina, estreitamente vinculados à religiáo que abraçavam. O que nos leva a aventar a hipótese de que poucos eram os investimentos destinados à formaçáo das mulheres. O discurso dos governantes sobre a falta de recursos para a educaçáo, principalmente para a educação rural, parece-nos ser uma forma auspiciosa de justificativa para o fato de delegar o ensino e a formaçáo feminina para o setor particular ou as escolas confessionais, como mais uma forma de exercer controle sobre elas.

\section{Referências}

ALMEIDA, Jane Soares de. Meninos e Meninas estudando juntos: os debates sobre as classes mistas nas Escolas Brasileiras: (1890/1930). Revista HISTEDBR On-line, Campinas, no 58, p. 115-123, set 2014 - ISSN: 1676-2584. Disponível em: https://periodicos.sbu.unicamp.br/ojs/index. php/histedbr/issue/view/691/showToc. Acesso em: 10 de outubro 2017.

ALMEIDA, Jane Soares de. Mulher e educaçáo: a paixão pelo possível. São Paulo. UNESP. 1998.

ALMEIDA, Jane Soares de. Mulheres na Educação: missão, vocação e destino? A feminização do magistério ao longo do século XX. SAVIANI, Dermeval et al. $\mathrm{O}$ legado educacional do século XX no Brasil. 2 ed. Revisada e ampliada. Autores Associados. Campinas, SP. p. 59; 94. 2004.

BRASIL. Constituiçáo da República dos Estados Unidos do Brasil, de 24 de fevereiro de 1891. Disponível em: http://www.planalto.gov.br/ccivil_03/ constituicao/constituicao91.htm. Acesso em: 10 de outubro 2017.

CORRÊA, Estevão Alves. Relatório da Instruçáo Pública apresentado ao Presidente Pedro Celestino Corrêa da Costa. Matto Grosso, 05 de abril de 1909. APMT. 1909.

CORRÊA, Estevão Alves. Relatório da Instruçáo Pública apresentado ao Presidente Pedro Celestino Corrêa da Costa. Matto Grosso, 27 de março de 1911. APMT. 1911.

CORRÊA, José Estevão. Relatório da Instrução Pública apresentado ao Presidente Antônio Corrêa da Costa. Matto Grosso, 02 de janeiro de 1897. APMT. 1897. 
CORRÊA, José Estevão. Relatório da Instrução Pública apresentado ao Presidente Antônio Corrêa da Costa. Matto Grosso, 03 de janeiro de 1898. APMT. 1898

COSTA, Antônio Corrêa. Mensagem do Presidente do Estado de Mato Grosso para Assembleia Legislativa de Mato Grosso. 01 de fevereiro de 1896. Cuiabá. Disponível em: http://www-apps.crl.edu/brazil/provincial/ mato_grosso. Acesso em: 08 de julho 2016.

COSTA, Antônio Corrêa. Mensagem do Presidente do Estado de Mato Grosso para Assembleia Legislativa de Mato Grosso. 01 de fevereiro de 1897. Cuiabá. Disponível em: http://www-apps.crl.edu/brazil/provincial/ mato_grosso. Acesso em: 08 de julho 2016.

FARIA FILHO, Luciano Mendes de. Dos Pardieiros aos Palácios: cultura escolar e urbana em Belo Horizonte na Primeira República. Passo Fundo: UPF, 2000.

GARDÉS, João Pedro. Relatório da Instrução Pública apresentado ao Presidente Manoel José Murtinho. Matto Grosso, 30 de agosto de 1892. APMT. 1892.

LEITE, Gervásio. Um século de instruçáo pública: história do ensino primário em Mato Grosso. Goiânia: Editora Rio Bonito, 1971.

LOURO, Guacira Lopes. Gênero, sexualidade e educação: uma perspectiva pós- estruturalista. 16 Edição. Petrópolis, RJ: Vozes, 2014.

LOURO, Guacira Lopes. Mulheres na Sala de Aula. In: DEL PRIORE, Mary (org.). História das Mulheres no Brasil. 9. ed. São Paulo: Contexto, 2015. p. 443- 481.

LOURO, Guacira Lopes. Prendas e antiprendas: uma escola de mulheres. UFRGS, RS, 1987.

MARCÍlIO, Humberto. História do Ensino em Mato Grosso. Cuiabá, Secretaria de Educação, Cultura e Saúde do Estado, 1963.

MATO GROSSO. Governo. Decreto no 10 de 07 de novembro de 1891. APMT - Livro de Leis e Decretos - 1891.

MATO GROSSO. Governo. Decreto no 68 de 20 de junho de 1896. APMT - Livro de Leis e Decretos - 1896.

MATTO GROSSO. Regulamento do Ensino Primário da Província de Matto Grosso. Cuyabá, 7 de junho de 1889. APMT - Livro de Leis e Decretos - 1889 . 
MATTOS, Sandra Jung de. Trabalho de agulhas e prendas domésticas: educação feminina Mato-Grossense (1889-1910). Dissertação de (Mestrado), Universidade Federal de Mato Grosso. Programa de Pós-Graduação em Educação, Cuiabá-M, 2018.

MENDES, Joaquim Pereira Ferreira. Relatório da Instrução Pública apresentado ao Presidente Manoel José Murtinho. Matto Grosso, 22 de abril de 1893. APMT. 1893.

MENDES, Joaquim Pereira Ferreira. Relatório da Instruçáo Pública apresentado ao Presidente Manoel José Murtinho. Matto Grosso, 09 de março de 1895. APMT. 1895.

MURTINHO, Manoel José. Mensagem do Presidente do Estado de Mato Grosso para Assembleia Legislativa de Mato Grosso. 13 de maio de 1895. Cuiabá. Disponível em: http://www-apps.crl.edu/brazil/provincial/mato_ grosso. Acesso em: 08 de julho 2016.

OSÓRIO, Pedro Leite. Mensagem do Presidente do Estado de Mato Grosso para Assembleia Legislativa de Mato Grosso. 13 de maio 1907. Cuiabá. Disponível em: http://www-apps.crl.edu/brazil/provincial/mato_ grosso. Acesso em: 12 de julho 2016.

PERROT, Michelle. As mulheres ou os silêncios da história. Tradução: Viviane Ribeiro. São Paulo: Edusc, 2005.

PERROT, Michelle. Os excluídos da história: operários, mulheres e prisioneiros. Tradução Denise Bottmann. Rio de Janeiro: Paz e Tema, 2006.

PINHEIRO, Rossana Kess Brito de Souza. Máe-esposa e professora: educadoras no final do Século XIX. 219 f. 2009. Doutorado em Educação Universidade Federal do Rio Grande do Norte, Programa de Pós-graduação em Educação. Biblioteca Depositária: Biblioteca Central Zila Mamede (UFRN), Rio Grande do Norte. 2009.

RODRIGUES, Maria Benicio. Estado - Educaçáo escola - Povo: a reforma mato-grossense de 1910. Cuiabá. EdUFMT, 2009.

ROMANELli, Otaiza Oliveira. História da educaçáo no Brasil. 8. ed. Petrópolis. RJ. Editora Vozes. 1986.

RONDON, Januário da Silva Rondon. Relatório da Instrução Pública apresentado ao Presidente Antônio Pedro Alves de Barros. Matto Grosso, 30 de dezembro de 1899. APMT. 1899. 
SOIHET, Rachel. A conquista do espaço público. In: PINSKI, Carla Bassanezi, PEDRO, Joana Maria. (org.). Nova história das mulheres no Brasil. São Paulo: Contexto. 2013. p. 218-237.

VERISSIMO, José. A Educaçáo acional. 3. ed. Editora Mercado Aberto: Porto Alegre, 1985.

VIEIRA, Alfredo José Vieira. Relatório da Instruçáo Pública apresentado ao Presidente Antônio Herculano de Souza Bandeira. Matto Grosso, 06 de junho de 1889. APMT. 1889. 


\section{PARTE II \\ ENSINO, EDUCAÇÃO E SUAS PRÁTICAS}




\title{
POLÍTICA DE ASSISTÊNCIA ESTUDANTIL E SEUS REFLEXOS NA PERMANÊNCIA/NÃO PERMANÊNCIA DE ESTUDANTES NO IFMT CAMPUS VÁRZEA GRANDE
}

\author{
Carminha Aparecida Visquetti \\ Maria Emilia de Castro Rodrigues
}

\section{Introdução}

Este artigo resulta de uma investigação realizada no decorrer do Mestrado Interinstitucional (Minter) entre o Programa de Pós-Graduação em Educação da Faculdade de Educação da Universidade Federal de Goiás e o Instituto Federal de Educação, Ciência e Tecnologia de Mato Grosso - IFMT, vinculada à linha de pesquisa Educação, Trabalho e Movimentos Sociais, a qual teve por objetivo investigar, compreender e analisar o movimento de permanência e de não permanência dos sujeitos trabalhadores do Proeja.

Neste artigo o recorte se dá a partir da ótica dos estudantes que permaneceram no curso e evidencia a forma pela qual a política de assistência estudantil contribuiu ou não para viabilizar o acesso, a permanência e êxito nessa modalidade de ensino. Apresenta-se o perfil socioeconômico dos sujeitos educandos trabalhadores da EJA no IFMT Campus Várzea Grande; a análise dos desafios e das dificuldades vivenciados durante o curso relativos ao processo de acesso, permanência e êxito escolar dos educandos.

A escolha dos sujeitos que compuseram o universo da pesquisa se deu em razão de ser a única turma de estudantes trabalhadores do Ensino Médio Integrado ao Curso Técnico em Serviços de Condomínio na modalidade proeja no Campus Várzea Grande. No estudo de caso, por meio da análise de documentos, entrevista semiestruturada e grupo focal, evidenciamos que as trajetórias de vida dos sujeitos trabalhadores são marcadas, em sua maioria, por percursos de vidas sofridas e históricos de rupturas na educação, sendo importante convencê-los de que a escola é um direito.

Em relação à EJA, existe no IFMT um alto índice de afastamento temporário e permanente de educandos, além do abandono do curso. Como exemplo, apontamos o Proeja no Campus Várzea Grande, que no período 2015/01 contava com trinta (30) estudantes matriculados e, ao final 
do curso ${ }^{1}$, em 2017/02 contou com somente nove (9) estudantes concluintes. Essa realidade nos fez/faz indagar: o que tem levado tantos estudantes trabalhadores a não darem continuidade em seus estudos, afastando-se do espaço escolar?

Diante dessa realidade, o grande desafio a enfrentar é o afastamento temporário ou definitivo, muitas vezes denominado "evasão". Recusamos utilizar essa terminologia, pois transfere para o educando a responsabilidade pela sua não permanência no curso, quando, na verdade, essa realidade também reflete a falta de condiçóes materiais de subsistência desses sujeitos, que por inúmeras razóes se encontram como subempregados, desempregados ou em trabalhos precarizados e/ou informais. Ainda contribuem para a "expulsão" desses estudantes trabalhadores: as não aprendizagens; as dificuldades de relacionamento com os pares e/ou professoras/professores e demais profissionais da unidade de ensino; a baixa autoestima, entre outros fatores.

\section{Traços que caracterizam os estudantes trabalhadores do PROEJA}

Com o objetivo de compreender os fatores que levam os sujeitos trabalhadores a permanecerem no Proeja, buscou-se, a partir da apresentaçáo do perfil socioeconômico, levantar algumas reflexóes sobre quem é esse estudante da EJA. O intuito desta análise é a compreensão das identidades dos cursistas do Proeja, o que possibilita ao IFMT conhecer um pouco melhor o estudante que permaneceu na instituição, contribuindo para a reflexão dos aspectos que possibilitam e/ou favorecem o afastamento e/ou permanência.

O perfil dos educandos foi levantado com base nos dados do Setor de Política de Ingresso do IFMT e da secretaria escolar do Campus de Várzea Grande, em complementação recorreu-se à realização de entrevista semiestruturada e grupo focal com os nove (9) sujeitos permanentes. Os dados referentes à análise socioeconômica apontaram: em relaçáo ao gênero, oito (8) pessoas são do sexo feminino, o que perfaz $88,9 \%$ do universo dos estudantes permanentes, enquanto uma (1) pessoa é do sexo masculino, ou

1 De acordo com o Projeto Pedagógico do Curso, seu público-alvo são estudantes maiores de 18 anos, que já possuem o ensino fundamental. O curso do Proeja no Campus contou com duração de três anos, com oferta e matrícula semestrais e aulas no período noturno. Possui carga horária de 2.440 horas-aula, das quais 833 horas são destinadas às componentes curriculares da base técnica do curso, 1207 horas aos estudos dos componentes da base comum e $400 \mathrm{~h}$ de prática profissional - Projeto Política Pedagógico do Curso. (PPC, 2014, p. 29). 
seja, $11,1 \%$ do total. Pelo fato de o curso pertencer ao eixo tecnológico Gestão e Negócios, o que chama atenção é a predominância do público feminino, visto que, via de regra, esse eixo tem registrado uma predominância do público masculino. Essas particularidades deveriam chamar a atenção para se pensar políticas públicas para o acolhimento dessas mulheres e discutir questôes de gênero.

Da mesma forma é necessário também pensar em estratégias e suporte escolar para as estudantes mães que possuem filhos ainda pequenos e não têm onde deixá-los para ir à escola, como expresso no seguinte relato:

[...] aí, como eu engravidei do meu filho, parei também [de estudar], porque eu já tinha o outro pequenininho e não tinha como continuar. Parei na oitava e depois de dez anos, ele com dez anos, eu vim me encaixar aqui de novo [...]. A dificuldade é nos momentos assim, meu marido não está em casa, porque tem que estar viajando, aí não chega, aí tenho que ficar trazendo as crianças pra escola. Então eu acho dificuldade, que além de terem que estudar durante o dia, fica cansativo para eles. Eu estou forçando, às vezes eles querem dormir, como já dormiram na sala, ficar deitadinho lá no chão [...]. (Estudante 10, entrevista, Várzea Grande, MT, 1\%/12/2016).

O depoimento mostra a importância de açóes educativas na perspectiva de empoderamento das estudantes trabalhadoras, no sentido de ampliar suas percepçóes de seres históricos transformadores de suas próprias realidades. Tais açôes auxiliariam, inclusive, em períodos de dificuldades na relação conjugal e até mesmo quando da separação dos cônjuges. Nesse sentido, destacamos as seguintes falas:

[...] No começo, foi muito difícil, difícil demais, né?, mas depois ele [o marido] teve que entender [...] às vezes ele não me apoia muito, mas eu falo para ele larga de ser besta, eu tenho que estudar, eu falo pra ele assim que preciso ajudar ele, né?, e se eu não buscar terminar a escola para poder fazer um curso melhor não vou arrumar um emprego para poder ajudar ele e as crianças, né?, porque não quero que as crianças ficam igual eu assim, que parei tanto tempo na escola [...]. (Estudante 9, entrevista, Várzea Grande, MT, $12 / 12 / 2016$ ).

[...] eu senti firmeza no que eu quero pra minha vida e no que eu vou levar comigo. Eu tive uma experiência [...] eu numa situação que você não quer ver ninguém, se você ama aquela pessoa, tu não quer ver, eu consegui, dei a volta por 
cima, foi duro, foi muito, muito duro. [...]. Eu fiquei, eu acho que uns três meses, três náo, um mês e pouco sem vir na escola. Quando a Elisângela [professora] pegou e disse assim 'Você pode, não é assim, não é isso que vai te derrubar, você tem que ir', eu falei: 'Não, eu vou'. E vou ver no que vai dar e é isso. [...]. Isso, não, ela me parou na porta da escola, eu trazendo meus filhos, e ela falou assim: 'Eu quero você aqui, eu vou te ajudar', mas eu disse: 'Professora, não dá mais, até passou muito e todo mundo já fez'; 'Não, mas você vai conseguir, nós vamos correr atrás, vamos conversar com os professores, você vai conseguir'. (Estudante 11, entrevista, Várzea Grande, MT, 18/12/2017).

Outro dado a ser considerado é que a maioria dos sujeitos trabalhadores possuem algum tipo de união conjugal. No Campus Várzea Grande, mais da metade dos sujeitos trabalhadores possuem algum tipo de uniáo conjugal, sendo que quatro pessoas $(44,4 \%)$ são casadas e uma $(11,1 \%)$ mora junto, ou seja, $55,5 \%$ possuem famílias e são responsáveis por elas. Uma pessoa é separada $(11,1 \%)$ e três $(33,3 \%)$ são solteiras, condição que reafirma a heterogeneidade no Proeja.

Em relação ao número de estudantes que residem na mesma casa com outros integrantes de suas famílias, 3 (33,3\%) estudantes responderam que dividem a casa com 5 (cinco) pessoas, outros $3(33,3 \%)$ estudantes dividem a casa com 4 (quatro) pessoas; $1(11,1 \%)$ pessoa divide a casa com 2 pessoas; $1(11,1 \%)$ pessoa divide sua casa com $3(11,1 \%)$ pessoas; $1(11,1 \%)$ pessoa divide a casa com 7 pessoas. Sabe-se que o contexto familiar é complexo, muito rico e pode influenciar na permanência ou não desses trabalhadores na escola. Reconhecendo que a família tem seu lugar de destaque em relaçáo ao cuidado, proteção e educação entre seus membros. Tanto que o Estado garante proteção especial, por meio de políticas públicas, conforme dispõe art. 226 da Constituição Federal, a família, base da sociedade, tem especial proteção do Estado. Quando há situaçôes excludentes nas famílias dos estudantes, como situação econômica relacionada a pobreza e ao desemprego, acesso à saúde, cultura, formação familiar, relaçóes familiares entre outros, a intervenção do assistente social visa proporcionar à família condiçóes para a superação da situação apresentada.

Nesse sentido, é importante que a escola implemente açóes e programas que valorizem o fortalecimento das unidades familiares. Domanski (2016, p. 85) aponta a diferença entre os estudantes da EJA e os mais jovens (crianças e adolescentes): 
Estes não precisam se preocupar com seu sustento, pois não precisam e não trabalham. No entanto, os educandos da EJA, na sua maioria, precisam optar entre estudo e trabalho, o segundo sempre será prioridade, pois é sinônimo de sustento, de sobrevivência. Sempre é possível voltar a estudar, no entanto, conseguir um trabalho e manter-se nele é mais difícil e, por isso, precisam fazer escolhas.

No tocante à idade ${ }^{2}$ dos estudantes, tomou-se como referência o Estatuto da Juventude de 2013, que considera jovens as pessoas entre 15 (quinze) e 29 (vinte e nove) anos ${ }^{3}$ (BRASIL, 2013), e observou-se a predominância do público de adultos $88,9 \%$ (8) em relação aos jovens $11,1 \%$.

Para a análise da composição étnica, utilizou-se a classificação racial utilizada nos levantamentos demográficos do Instituto Brasileiro de Geografia e Estatística - IBGE . Assim, quanto à forma de auto identificação dos estudantes duas (2) pessoas se autodeclararam brancas $(22,2 \%)$, e sete (7), pardas $(77,8 \%)$. Esses dados confluem com o documento base do Proeja quando destaca que o trabalho da EJA é marcado por sujeitos marginais ao sistema, com atributos sempre acentuados em consequência de alguns fatores adicionais como raça/etnia, cor, gênero.

No que diz respeito ao trabalho, um estudante $(11,1 \%)$ não trabalhava, quatro $(44,4 \%)$ estavam desempregados, percentagens que, somadas, representam mais da metade dos estudantes permanentes fora do mercado de trabalho. Quatro estudantes (44,4\%) disseram que trabalhavam em tempo integral ou mais de 6 horas por dia, mas apesar disso afirmaram estar motivados em busca de aprendizado. Em relaçáo a renda, 88,9\% (8) perfazem os educandos com renda familiar entre um e três salários mínimos.

2 Já a delimitação etária de juventude da Organização das Nações Unidas (ONU) define os jovens como indivíduos que estão na faixa etária entre 15 (quinze) e 24 (vinte e quatro) anos de idade. Todavia, a Organizaçáo Mundial da Saúde (OMS) considera as pessoas de 15 (quinze) a 19 (dezenove) anos como jovens adolescentes e as de 20 (vinte) a 24 (vinte e quatro) anos, como adultos jovens.

3 Já a delimitação etária de juventude da Organização das Nações Unidas (ONU) define os jovens como indivíduos que estão na faixa etária entre 15 (quinze) e 24 (vinte e quatro) anos de idade. Todavia, a Organização Mundial da Saúde (OMS) considera as pessoas de 15 (quinze) a 19 (dezenove) anos como jovens adolescentes e as de 20 (vinte) a 24 (vinte e quatro) anos, como adultos jovens.

4 A atual classificação racial do IBGE é tomada como oficial desde 1991 e utilizada para fins demográficos no Brasil. Tal classificação tem como diretriz, essencialmente, o fato de a coleta de dados se basear na autodeclararão. Ou seja, a pessoa escolhe, de um rol de cinco itens (branco, preto, pardo, amarelo e indígena) em qual deles se aloca (OLIVEIRA, 2004). 
É o trabalho precário, informal, repetitivo, estafante, que está presente na vida da maioria dos sujeitos trabalhadores do Proeja, obrigados, desde muito cedo, quando ainda crianças, a trabalhar para ajudar na composição da renda familiar.

\begin{abstract}
[...] Eu fiz até a quarta série, parei porque, no caso, quando eu tinha 12 anos [...], todo mundo precisava trabalhar em casa, ajudar os pais em tudo. A gente tinha que trabalhar, não tinha jeito, eu comecei a trabalhar com meus 12 anos e larguei a escola de vez [...]. Trabalhava como diarista e cuidava das crianças, mas era aquela diarista que dormia no local, ia na segunda-feira e só voltava na sexta ou sábado, entáo tinha esse período todinho que eu ficava na casa dos outros. (Estudante 10, entrevista, Várzea Grande, MT, $1 \% / 12 / 2016)$
\end{abstract}

E mesmo nos dias atuais é o trabalho terceirizado e precário, que remunera muito pouco, que está presente no dia a dia dos educandos e é lembrado no depoimento:

[...] Eu chegava para trabalhar entre 9 e 10 horas e saía as 11 horas da noite, meus pés e minhas pernas inchavam tudo [...]. Eu trabalhava de fazer uniforme, eles pagavam 1 real por camiseta [...] e como já estava acostumada, eu fazia até 100 camisetas em um dia [...] eu entregava limpinha a camiseta para eles só dobrarem [...]. Hoje de vez em quando eu faço bicos em alguns lugares, só que as empresas mandam muita gente embora [...] e ainda quando ia pagar e ficava faltando centavos, você vai brigar com o cara por causa de um real? [...] é uma profissão que quem trabalha por trás das empresas de uniforme, eu acho uma exploração [...] porque eles vendem a 18, 19, 20 reais uma camiseta, eles têm coragem de te pagar 1 real, sem contar os descontos, porque eles descontam alimentação. [...]. Eu ficava trabalhando sábado e domingo, entáo você tem que aceitar o que eles mandam [...]. (Estudante 9, entrevista, Várzea Grande, MT, 12/12/2016).

Eu acordo às 4 horas da manhã, vou dormir lá pelas 10, 11 horas, com duas filhas, dois anjos. Eu não posso ficar cansada, nem pensar que estou cansada, senão a casa cai, o mundo cai [...]. Estou desempregada, tem um mês e pouco, mas não estou parada, eu sempre faço diária quando um menino me chama na imobiliária, só estou nisso por enquanto [...]. (Estudante 8, entrevista, Várzea Grande, MT, 06/12/2016). 
O trabalho perene ganha destaque, pois na maioria das vezes desperta esperanças de melhores salários, como se observa no relato a seguir.

\begin{abstract}
[...] trabalho como diarista, mas minha profissão era costureira [de facção], mas eu estava muito cansada de ficar sentada o dia inteirinho atrás de uma máquina e ficava trabalhando, trabalhando... e o final do mês é só aquele salarinho mesmo e eu falava: 'Não é possível'. [...]. Aí minha irmã trabalha como diarista, ela me disse que o trabalho é pesado, mas era o único que dava dinheiro [...] e foi assim difícil, porque eu nunca tinha trabalhado assim. (Estudante 6, entrevista, Várzea Grande, MT, 1\%/12/2016).
\end{abstract}

Ainda há o estudante que, por considerar que não tem um emprego registrado em carteira, desempenha o trabalho em casa, que é tão exigente e estafante como qualquer outro: "[...] Atualmente, eu só sou do lar e, estando em casa, sempre você acha alguma coisa pra estar fazendo, então a carga horária é o tempo que você estiver em casa, é o tempo que você está trabalhando". (Estudante 6, entrevista, Várzea Grande, MT, 1\%/12/2016)

Essa realidade vivida por grande parte dos estudantes trabalhadores tem de ser observada pela escola para que repense o modelo de trabalho tradicional, pois a dinâmica/ rotina a que são submetidos é outra. Como então exigir do estudante trabalhador requisitos/ critérios que não fazem parte de sua realidade? Importante mencionar que parte da não permanência do estudante trabalhador na escola também é justificada pela necessidade do trabalho e pelo cansaço, que pesa depois de um longo dia. O Estudante 7 relata sua rotina de trabalho na administração de 96 apartamentos: “[...] não tem assim um horário de trabalho, a gente tem que ficar igual médico, 24 horas. Então, se acontecer alguma coisa na madrugada, chama o síndico”. (Estudante 7, entrevista, Várzea Grande, MT, 5/12/2016)

O resultado é muito significativo e coaduna com os pressupostos trazidos pelo Documento Base do Proeja, que registra que a maioria dos estudantes do programa apresenta um perfil de subemprego, desemprego e trabalho informal, reflexo de uma sociedade que segrega grande parte da populaçáo desfavorecida econômica, social e culturalmente (BRASIL, 2007). Fica evidente que na maioria das situaçóes, o trabalho desses estudantes não é mera opção, mas sim questão de sobrevivência. Assim, se tiverem que optar entre trabalhar e comer ou estudar e ficar com fome, muitos, sem sombra de dúvida, optaráo pelo trabalho. 


\section{O acesso permanência e êxito no PROEJA}

Não basta discutir a questão da permanência e/ou êxito dos estudantes no Proeja se não se garantir o acesso deles ao programa. A premissa seria o compromisso institucional, na perspectiva de promover a inclusão e atender à demanda regional, conforme dispóe o art. 2, $\$ 1^{\circ}$ do Decreto n. ${ }^{\circ}$ 5.840/2006 que determina que as Instituiçóes Federais deverão disponibilizar ao Proeja "no mínimo dez por cento do total de vagas de ingresso da instituição, tomando como referência o quantitativo de matrículas do ano anterior".

Porém, percebe-se que esse direito conferido aos estudantes trabalhadores não é efetivado, a exemplo do curso do Proeja no IFMT Campus Várzea Grande que foi extinto, a situação de outros Campi não é diferente. Atualmente, dos dezenove (19) Campi do IFMT apenas 7 ofertam curso na modalidade Proeja, observamos dessa forma que não há o empenho da instituição no cumprimento da oferta de $10 \%$ das vagas, o que demonstraria o compromisso da instituição com o atendimento a um grupo de pessoas mais carentes, haja vista que o Proeja é uma política pública de inclusão social. Essa realidade é o exemplo de como, ao longo da história da educação, as políticas públicas que tratam a EJA são desenvolvidas não como um processo, mas de forma pontual. A esse respeito, diz Arroyo (2005, p. 48-49):

Os jovens e adultos da EJA são uma denúncia clara da distância intransponível entre as formas de vida a que é condicionada a infância, adolescência e juventude populares e a teimosa rigidez e seletividade de nosso sistema escolar. Olhar-se no espelho das trajetórias dos jovens e adultos que voltam à EJA talvez seria uma forma do sistema reconhecer a distância intransponível. Não foi a EJA que se distanciou da seriedade do sistema escolar, foi este que se distanciou das condiçôes reais de vida dos setores populares. A educação de jovens e adultos avançará na sua configuração como campo público de direitos na medida em que o sistema escolar também avançar na sua configuração como campo público de direitos para os setores populares em suas formas concretas de vida e sobrevivência.

Cabe destacar a forma de acesso desses estudantes trabalhadores na instituição, quando se indaga, por meio de conversa informal com os diretores dos campi, o porquê da não oferta ou do fechamento do curso. A resposta, invariavelmente, é a de que não há procura dos estudantes para a referida modalidade. Porém, o que se percebe é que muitas vezes a instituição não tem clareza de que o Proeja possui especificidades que, se não forem observadas, 
podem ser um elemento determinante para o sucesso/insucesso da procura e permanência desses estudantes no curso.

Em relação ao não cumprimento do percentual mínimo de vagas em cursos do Proeja, algumas açóes são essenciais e devem ser observadas, pois poderiam alavancar a demanda pelos cursos ofertados pelos Ifs. Há de se pensar, inclusive, sobre a forma de inscrição e de como é realizada a divulgaçáo dos cursos, estabelecer parcerias com outras instituiçóes, com os Centros de Referência de Assistência Social - CRAS 5 da região.

Um aspecto identificado que dificulta o acesso é a seletiva dos estudantes do Proeja - pagamento de inscrição, prova e horário das entrevistas, pois confirmam que é preciso uma mudança no que está sendo praticado no processo seletivo para o Proeja.

A necessidade de compreender que o público do Proeja são estudantes trabalhadores e que muitos tiveram na trajetória de suas vidas a marca da exclusão dos espaços formais da educação é muito importante, e deve ser considerada quando se elabora o projeto pedagógico do curso com uma proposta de carga horária extensa e não flexível à sua realidade de trabalhador, ocasionando muitas vezes os estudantes trabalhadores desistirem de continuar seus estudos, sendo novamente expulsos pela escola:

A educação emancipadora não se realizará sob as condições institucionais presentes na Política de Educação, cuja função central é de mediar os processos de reproduçáo da sociedade do capital, ainda que muitas sejam as referências produzidas em diferentes campos profissionais sobre as possibilidades de uma educação 'crítica' ou 'cidadâ' nos marcos da atua política educacional. (CFESS, 2011, p. 21).

Noro (2011) e Pereira (2011) destacam que o principal empecilho ao acesso dos trabalhadores à escola é a necessidade que têm de trabalhar para o sustento próprio e da família e o nível de escolaridade dos pais.

5 De acordo com o Ministério de Desenvolvimento Social e Combate à Fome (2009), o Centro de Referência de Assistência Social - CRAS é uma unidade pública estatal descentralizada da política de assistência social, responsável pela organização e oferta de serviços de proteção social básica do Sistema Único de Assistência Social - SUAS nas áreas de vulnerabilidade e risco social dos municípios e DF, além da oferta de serviços e ações. Possui as funçóes exclusivas de oferta pública do trabalho social com as famílias do PAIF e de gestão territorial da rede socioassistencial de proteção social básica. Tem como objetivo prevenir a ocorrência de situaçôes de vulnerabilidades e riscos sociais nos territórios, por meio do desenvolvimento de potencialidades e aquisiçóes, do fortalecimento de vínculos familiares e comunitários, e da ampliação do acesso aos direitos de cidadania. Disponível em: http://www.mds.gov.br/webarquivos/publicacao/assistencia_social/ Cadernos/orientacoes_Cras.pdf. Acesso em: 10 ago. 2017. 
Como fatores de permanência, apontam a qualidade do trabalho docente, o acolhimento e a qualidade da estrutura da instituição e das políticas de assistência estudantil. Ainda, segundo o autor, apresenta-se como principal desafio do Proeja a "[...] necessária mudança na forma como vemos estes estudantes para que entrem, permaneçam e aprendam [...]”. Estas conclusóes são reafirmadas pela presente pesquisa.

Pensar em estratégias de flexibilização na oferta dos cursos no Proeja é ressignificar os paradigmas que sustentam a ideia de educação "inclusiva" e "cidadâ”. São estratégias de luta da classe trabalhadora na superação das formas de institucionalização dos direitos sociais. É nessa perspectiva que Freire (2011) aponta que o currículo escolar deve partir do povo, da sua realidade e vivências e defende que o currículo deve ser um instrumento significativo na produção do conhecimento. Dessa forma, os conceitos e práticas preestabelecidos e cristalizados na EJA devem passar por uma reforma significativa na construçáo de um currículo feito com o povo, e não sem ele.

Como se pode observar em alguns dos relatos dos estudantes trabalhadores entrevistados nesta pesquisa, é notório que a aprendizagem escolar, para esses sujeitos, só se torna significativa quando eles conseguem usar seus saberes prévios. Esses saberes, legitimados pela sociedade e, sobretudo, pela escola, possibilitam que os saberes novos do mundo letrado ganhem sentido em suas vidas cotidianas. Cabe destacar o depoimento de uma ex-aluna do Proeja IFMT Campus Várzea Grande que, após cursar uma disciplina, fez a instalação hidráulica de sua casa:

[...] Eu mesma fiz a instalação hidráulica com o que aprendi na aula. Eu fui lá, comprei os canos e fiz tudinho, fiz as conexôes. [...] eu construí a casa e fiz a parte hidráulica [...] eu construí a casa em dois meses, só pra ficar aqui. Eu estava desempregada, saí da empresa que eu era representante e quis fazer o curso. Comprei o lote lá e fiz a casinha lá pra mim, mas eu fui buscar nas caçambas coisas recicladas e fiz [...]. (Estudante 4, entrevista, Várzea Grande, MT, 6/12//2016).

Tais práticas, inclusive, auxiliam a superação dos entraves que são postos pelos próprios estudantes trabalhadores, como destacado nos relatos abaixo:

[...] Eu odiava matemática [...] ele [o professor...] disse que matemática náo era esse pesadelo que eu achava, ele me mostrou que a matemática está em todos os lugares e que você tem que aprender a mexer na matemática, porque senão você vai perder dinheiro por aí. [...] Ele começou a me 
ajudar, ensinar as regrinhas de matemática, coisa e tal. Eu tenho um pouco de dificuldade, entendeu?, mas a maioria da dificuldade ele que me ajudou a superar [...]. (Estudante 3, entrevista, Várzea Grande, MT, 13/03/2016).

[...] Ele [o professor] começou conversando com a gente, se bem que já tinha começado a turma, mas cada um que vinha chegando, entrando, ele perguntava quanto tempo estava sem estudar, a dificuldade, ele olhava onde que estava a dificuldade da gente naquele primeiro momento. E ele foi tudo ali bem no nível da gente, conforme se precisasse voltar, ele voltava lá de novo, então isso foi cativante porque logo você se encaixou [...] e você foi vendo que também os outros alunos tinhas dificuldades. Então eu falava: Nossa, não sou só eu que estou assim, que pensa assim, tem outras pessoas, entáo um dava força pra outra, se ajudando: 'Oh, te ajudo aqui[...]' Então, nesse momento, aí foi pra frente. (Estudante 10, entrevista, Várzea Grande, MT, $1 \% / 12 / 2016)$.

O destaque está no incentivo e na compreensão do professor ante as limitaçóes que os estudantes apresentavam e que náo eram vistas como fator limitante, pelo contrário, eram encaradas como um ponto a ser superado. A trajetória escolar desses sujeitos também fica marcada, como se percebe neste depoimento:

[...] O que me marcou foi uma nota muito boa que eu levei de matemática [...]. O professor, muito compreensivo, ajudava muito a gente... assim, não dando nota ou coisas assim, na compreensão, né?, ele pedia assim para ela [a colega de sala] dar uma aula de reforço pra mim. Até que eu fiquei pendente de fazer uma prova, porque náo alcancei a média e nisso aí eu fiz, estudei a tarde toda com ela e cheguei lá e tirei uma nota muito alta, e fiquei muito feliz, porque concluí aquilo, corri atrás e consegui. [...]. (Estudante 1, entrevista, Várzea Grande, MT, 25/05/2016).

O estudante recebeu o incentivo não só do professor, mas também de outro colega, estreitando laços de solidariedade entre docente-discente e discentediscente e promovendo a elevaçáo da autoestima. E aqui também salienta-se a importância do(s) grupo(s) de estudo(s), em especial por ser a linguagem da/o colega mais próxima dos educandos que a do professor/a, e se o professor solicitou à colega para auxiliá-la é porque sabia que esta já tinha o domínio do conteúdo. $\mathrm{O}$ que confirma o entendimento de que os conteúdos de ensino, para esta modalidade, devem partir de seus interesses, das suas vivências. 
Assim, além das atividades práticas, as viagens e visitas técnicas destacam-se como elementos de estímulo aos estudantes trabalhadores.
[...] a aprendizagem ativa ocorre quando o aluno interage com o assunto em estudo - ouvindo, falando, perguntando, discutindo, fazendo e ensinando - sendo estimulado a construir o conhecimento ao invés de recebê-lo de forma passiva do professor. Em um ambiente de aprendizagem ativa, o professor atua como orientador, supervisor, facilitador do processo de aprendizagem, e não apenas como fonte única de informaçáo e conhecimento. (BARBOSA; MOURA, 2013, p.55).

Além desta prática ser vista como facilitadora das aprendizagens, as visitas técnicas são consideradas, pela maioria dos estudantes entrevistados, como um dos três aspectos positivos do Proeja, que a veem como um divisor de águas em suas vidas, por serem marcadas não só pelo aprendizado, mas também pelo estreitamento do laço afetivo entre eles:

[...] foi muito importante para mim [...] a viagem em que nós fomos ver a feira de construçáo civil. Dentro do nosso curso, que é a área de condomínio, nós tivemos a oportunidade de ir com a escola, ir para uma feira de construção civil, que foi muito avaliado, foi muito bacana, muito rico [...]. (Estudante 4, entrevista, Várzea Grande, MT, 6/12/2016).

Muito conhecimento [...] nem imaginava assim, vocês vão pra São Paulo, 'Ah eu vou', mas você ir e chegar lá e ter um leque de conhecimento ali, você fica maravilhada [...] de tanta coisa assim, muito conhecimento [...]. Sonhei com tantas possibilidades [...] e a força de vontade de buscar agora muito mais conhecimento, a escola desenvolve teu conhecimento em todas essas aulas de conhecimento me fez ver que tudo é possível, tudo é possível. (Estudante 9, entrevista, Várzea Grande, MT, 12/12/2016).

No tocante à permanência e êxito dos estudantes do Proeja, se optou pela utilização do termo permanência/não permanência em detrimento de "evasão escolar”, que é adotado pelo sistema oficial de ensino. Tal opção parte do princípio de que na maioria das vezes evasão escolar levar a crer que as causas da não permanência na escola são de responsabilidade exclusiva do estudante, como se essa fosse uma opção ativa e autônoma do sujeito. Paulo Freire (2006) recusa o uso desse termo, por considerar que os estudantes não se evadem da escola, não a deixam porque querem, e sim porque são expulsos ou, em função de determinadas condiçóes, são obrigados a deixá-la: 
É a estrutura mesma da sociedade que cria uma série de impasses e de dificuldades, uns em solidariedade com os outros, de que resultam obstáculos enormes para as crianças [jovens, adultos, idosos] populares não só chegarem à escola, mas também quando chegam, nela ficarem e nela fazerem o percurso a que têm direito. (FREIRE, 2006, p. 35).

Lemos e Carmo (2016) apontam que a evasão e permanência/não permanência são institutos diferentes, além do que, segundo os autores, há um dos aspectos da contradição existente no conjunto de publicaçóes relativas às referidas temáticas. Eles argumentam, ainda, que existe uma incipiente discussão sobre o conceito de permanência escolar cujo caráter que assume como dimensão da qualidade de ensino. Em suma, consideramos que a "evasão escolar" é um conceito amplo, polissêmico, e que apenas aponta os fatores de causas, já as proposiçôes para minorar essa situação são incipientes e não usuais.

\section{A política de assistência estudantil no cenário do PROEJA}

Entender a educação como um direito e que deve ser estendida e garantida a todos ainda é um dos grandes desafios no campo da educaçáo de jovens e adultos, não só para os próprios jovens, adultos e idosos que tiveram ao longo de suas vidas este direito negado, como para os gestores das políticas públicas e grande parte da população em geral, que pensam que o tempo da escolarização destes sujeitos da modalidade EJA já passou ou não vale a pena investir na educação destes. Contudo, mais uma vez reforçamos, trata-se de um direito de todo cidadáo ter acesso e garantia da educação de qualidade social. E também nesse processo é fundamental introduzir no debate a discussão e o fortalecimento da política de assistência estudantil, em especial, voltada ao público do Proeja, uma vez que causa impacto direto na permanência e conclusão dos cursos com êxito pelos estudantes do IFMT, que, em sua grande maioria constituem um perfil de vulnerabilidade social e/ou econômica.

Nessa perspectiva, é importante a interface colaborativa entre as políticas de assistência social e de educação e o conhecimento das competências das demais políticas intersetoriais, que, em conjunto, ampliam o comprometimento com o bem-estar do estudante. Na perspectiva neoliberal, como destaca Souza (2017, p. 18), o repasse dos auxílios financeiros é carregado de estigmas: 
$\mathrm{Na}$ ótica neoliberal, o caráter de auxílio financeiro da Assistência Estudantil atrela a sua imagem a um conjunto de signos que a identifica como portadora de estigmas relacionados ao 'não produtivo' e 'ao não trabalho', e como tal, as suas açóes passam a se desenvolver no limbo de um sistema que atribui valor aos indivíduos pela sua capacidade de produzir riqueza para a reprodução do próprio sistema por meio da venda da sua força de trabalho no mercado laboral.

A articulação entre a assistência social e a educação, mediante a formação crítica e cidadá, constitui-se como ação desafiante, dado o contexto sócio histórico neoliberal, que tem como principal agente de bem-estar social o mercado, que enaltece a individualidade e a meritocracia. Essa articulação entre a assistência social e a educação, portanto, é a defesa contra a orientação do mercado, pois se baseia na perspectiva dos direitos de cidadania social.

Percebe-se a importância e a necessidade urgente de um trabalho mais ativo com a comunidade escolar, de forma a esclarecê-la de que a assistência estudantil consiste em uma política, e que, como tal, se refere a um direito. Quando se indaga aos sujeitos trabalhadores do curso do Proeja do IFMT Campus Várzea Grande sobre a concepção de assistência estudantil que têm, percebe-se o repasse dos benefícios como um direito ou como uma benemerência do Estado, conforme mostram as respostas a seguir.

[...] Eu não vejo como assim... uma ajuda da escola e um incentivo para mim, mas não vejo como um direito que a escola tem que me dar. Eu vejo que a escola tá assim... buscando por mim uma ajuda. [...]. (Estudante 1, grupo focal, Várzea Grande, MT, 12/12/2017).

[...] Porque toda a escola que eu passei eu nunca ouvi falar disso, a verdade é essa[...]. (Estudante 4, grupo focal, Várzea Grande, MT, 12/12/2017).

[...] O IF é diferenciado, mas nós temos direito, eles têm recurso para dar esse auxílio para nós, até mais. O IF trabalha valorizando o nosso direito, porque nós temos direito [...]. (Estudante 2, grupo focal, Várzea Grande, MT, 12/12/2017).

Fica evidente na fala dos sujeitos entrevistados que eles possuem uma visão truncada da assistência estudantil. Ou seja, para alguns, a assistência estudantil se configura como um ato de bondade da instituiçáo, e não um direito legítimo que é. 
[...] Esse dinheiro do IF me ajudou muito, não só eu como meus filhos. Eu não vejo que é só um direito que vocês fazem de tudo para ajudar o aluno. Tá certo é um direito meu como aluna é, mas vocês ajudam. Querem fazer o máximo possível para ajudar o estudante. Eu não vejo que é uma questão de dinheiro [...]. (Estudante 11, entrevista, Várzea Grande, MT, 18/12/2017).

Durante uma das entrevistas, uma discente afirmou que a assistência estudantil é um direito que muitas vezes lhe é negado, ainda que na perspectiva de ser uma prerrogativa legal. Todavia, a percepção da discente evidencia que, socialmente, nem sempre essa prerrogativa é uma garantia para o acesso aos direitos sociais. Com relação ao IFMT, percebe-se que esse direito precisa ser cumprido, pois, além de se tratar de um dever social, é também o cumprimento da função social de uma instituição formadora.

Subentende-se, por meio das legislaçóes que garantem o acesso, a permanência e a conclusão dos cursos pelos estudantes, que esse assunto esteja pacificado, já que está previsto na lei maior do país, a Constituição Federal de 1988, e na LDB, Lei no 9.394/1996 que prevê no Título III, no âmbito do Direito à Educação e do Direito de Educar, por exemplo.

No IFMT, a Política de Assistência Estudantil do IFMT funda-se na LDB n. ${ }^{\circ} 9.394 / 1996$ e na Portaria Normativa MEC n. ${ }^{\circ}$ 39, de 12 de dezembro de 2007, que institui o Programa Nacional de Assistência Estudantil, e no Decreto n. 7.234 , de 19 de julho de 2010. Além das Resoluçóes 94 e 95 de 18 de outubro de 2017 estruturadas conforme o quadro a seguir:

\section{Quadro 1 - Estrutura da Política de Assistência Estudantil do IFMT.}

\begin{tabular}{|l|l|}
\hline \multirow{4}{*}{ Programa Universal } & - Acolhimento e acompanhamento social, psicológico e \\
& pedagógico; \\
& - Prevenção e promoção à saúde e qualidade de vida; \\
& - Incentivo às atividades esportivas, de lazer e culturais; \\
& - Seguro escolar; \\
& - Incentivo ao Desempenho Escolar e Acadêmico - Monitoria \\
& Didática. \\
\hline \multirow{5}{*}{ Programa de Incentivo à } & - Auxílio moradia; \\
& - Residência Estudantil; \\
& - Auxílio Transporte; \\
& - Auxílio Alimentação; \\
& - Auxílio Creche; \\
& - Auxílio Permanência; \\
& - Auxílio Emergencial. \\
\hline
\end{tabular}

Fonte: Elaborado pela autora, com dados da Política de Assistência Estudantil do IFMT (2017). 
O Programa Universal abrange todos os estudantes matriculados no IFMT. Já o Programa de Incentivo à permanência é voltado aos estudantes em situação de vulnerabilidade social e/ou econômica, tendo como requisito para ser beneficiários/as de bolsas/auxílios serem aprovados por editais específicos.

Outro desafio é o entendimento comum de que o Serviço Social está na instituição apenas para realizar o repasse de auxílios e verbas estudantis, sem considerar a dimensão político-pedagógica do Serviço Social. É o fenômeno que Cislaghi e Silva (2011) designam de "bolsificação" e que é outro desafio que se apresenta, uma vez que exclui do debate a necessidade da ampliaçáo dos direitos, constituindo-se em uma tendência à assistencialização das políticas sociais.

É necessária a implementação de um plano de açáo nas escolas da rede federal para contribuir para a consolidação e ampliação da política de assistência estudantil, pois essa discussão ocorre de forma multifacetada. Segundo Taufick (2013, p. 53-54):

Tanto a Assistência Estudantil deve ser discutida sob o ponto de vista de múltiplas funçóes - social, pedagógica, psicológica -, como também a perspectiva socioassistencial pode ser expandida em torno de diversos aspectos, como por exemplo, o risco social presente em situaçóes de falta de moradia, violência familiar e urbana, envolvimento com drogas, entre outros.

Por vezes essa realidade é vivenciada pelo Serviço Social no Campus Várzea Grande, como podemos identificar quando esta pesquisadora indagou aos estudantes trabalhadores em relação aos benefícios concedidos pela assistência estudantil:

[...] Eu vejo como assim, eu vejo como um direito, eu vejo como uma ajuda da escola, uma ajuda, um incentivo pra mim, mas não que não vejo como um direito que a escola tem que. Eu vejo que a escola está fazendo assim, buscando por mim, uma ajuda [...]. (Estudante 11, entrevista, Várzea Grande, MT, 18/12/2017).

Os relatos chamam a atenção no sentido de auxiliar a construção de uma política de assistência estudantil comprometida com a perspectiva universalizadora e a partir das necessidades dos estudantes, que, na maioria das vezes, não têm conhecimento dos serviços ofertados. Destaca-se, portanto, a importância de uma ampla divulgação, para a comunidade interna e a sociedade em geral, da política de assistência estudantil, dos programas, das 
açóes, dos recursos e dos critérios de acesso a ela no Campus Várzea Grande. A assistência estudantil, afinal, é um direito social que deve estar claro para a comunidade do Campus, objetivando a sua melhoria. Nesse sentido, o envolvimento dos estudantes é essencial para o planejamento e a avaliação da política, potencializando, inclusive, a dimensão político-pedagógica da prática profissional do Serviço Social Escolar.

\section{Considerações finais}

Sob o olhar dos educandos, a pesquisa reafirmou que a efetivação do Proeja náo depende apenas da existência de um programa de governo que tenha princípios traçados e definidos, e sim da garantia de uma efetiva participação de todos os sujeitos, educandos trabalhadores, educadores, gestores públicos, pesquisadores, dentre outros, nos processos de pensar e fazer as políticas educacionais de efetivação do Proeja. E, ainda, que as instituiçóes proponentes do Proeja precisam valorizar de fato a EJA, a começar pela garantia do acesso, com a oferta dos cursos à comunidade, e a adoção de uma política que contemple os fundamentos políticopedagógicos, mas que também ofereça condiçóes materiais objetivas para que gestores e professores tenham espaços de formação, gestão e planejamento que contribuam para a implementação com qualidade social da política no meio institucional.

Faz-se necessário não só reconhecer que há muitas açôes e procedimentos no IFMT ainda inadequados ou insuficientes em relação à garantia da qualidade educacional aos estudantes do Proeja, como é preciso que se materialize o desejo pela comunidade escolar em promover discussóes entre seus membros, como gestores, docentes, técnicos administrativos, estudantes, secretarias de educação, associação de moradores e demais instituiçóes que dialoguem com o Proeja, seja de forma direta ou indiretamente.

Apesar dos recursos cada vez mais escassos decorrentes de cortes de investimentos por parte do governo federal na área da educação, não podem ser argumento nem justificativa para a falta de compromisso e para a educaçáo de adultos não ser tomada como política de real prioridade pelos gestores. A eficiência da gestão está na capacidade política de conduzir a máquina estatal, promover convênios para cumprir essa função social.

Ao refletirmos sobre as temáticas relacionadas ao acesso, observamos que a universalização da educação no IFMT não vem sendo atendida em relação aos valores e princípios constitucionais que se apresentam como direito público 
subjetivo, tanto que, atualmente dos 19 (dezenove) Campi do IFMT apenas 7 (sete) Campi ofertam o Proeja, sendo que 2 (dois) Campi estáo com o curso do Proeja em extinção. Todavia, observamos que não basta apenas o acesso, mas é preciso garantir a questão da permanência dos alunos.

Há inúmeras outras especificidades que devem ser consideradas pela comunidade escolar para a oferta de um curso do Proeja. A pesquisa apontou algumas que possibilitam perceber que, se há baixa procura pelo curso el ou alto índice de não permanência, é preciso repensar em relação à forma de oferta dos cursos, sobretudo no que diz respeito aos horários e dias da semana em que as aulas são ofertadas e à forma como são utilizados os recursos didáticos. Isso porque quando os educandos do Proeja, ao retornar à sala de aula, deparam-se com práticas novas e com o uso de recursos didáticos com os quais não estão habituados.

Percebe-se a importância de viabilizar o acesso ao Proeja de acordo com as especificidades dos sujeitos, além da necessidade de se questionar sobre qual tipo de escola ou de curso está sendo ofertado a eles. É um fator limitante de acesso a exigência de realização de provas, pois a maioria dos estudantes tiveram constantes interrupçóes escolares e/ou permaneceram por um longo tempo fora das salas de aula. $\mathrm{O}$ interessante é a adoção de entrevistas, porém, há de se observar os horários de agendamento delas.

Destaca-se que não é o perfil do estudante que não se encaixa na escola ou no tipo de curso ofertado; é a instituição que precisa lançar estratégias de acolhimento e elaborar um currículo pensado com e para os sujeitos trabalhadores. Mas para que isso aconteça, faz-se necessário, desde os primeiros dias de aula, conhecer os anseios e perspectivas dos estudantes trabalhadores para que se possa acolhê-los, adequar o curso aos seus perfis e às suas demandas. Muitas vezes esse trabalhador chega à escola desmotivado, ansioso, receoso, e por isso deve-se respeitar o ritmo de cada um e fazer da avaliaçáo um momento de aprendizagem.

O acolhimento na instituição, outro aspecto importante, perpassa por: apoio familiar; apoio pedagógico; repasse de bolsas e auxílios da Assistência Estudantil; criar neles o desejo em dar prosseguimento aos seus estudos; incentivo por parte dos professores; satisfação pessoal. Percebeu-se também que não só a comunidade escolar, mas também a família é parte importante do processo de convencimento para a volta à escola.

Outro ponto a se destacar em relação ao acesso é o convencimento dos estudantes trabalhadores de que a escola é também o seu espaço de ocupação e assim motivá-los, porque são o tipo de público que precisa ser convencido 
do seu direito à educação. Isso ocorre, geralmente, em função de sua baixa autoestima, historicamente construída pelas repetidas repetências, pelos afastamentos temporários das escolas e pelos modos como foram tratados nos espaços escolares e fora deles. Por isso, a maioria dos trabalhadores considera, entre outros aspectos, que seu tempo de estudo já passou, ou que são incapazes de aprender, e que o direito à escola seria só para as crianças e jovens.

Ressalta-se a importância da política de assistência estudantil como elemento favorecedor do acesso, da permanência e do êxito dos estudantes trabalhadores no processo de escolarização. Observou-se que há poucas produçóes científicas sobre o tema, o que revela quão incipiente é a discussão da política de assistência estudantil. A realidade em torno do Campus Várzea Grande não está imune à realidade nacional.

Observamos que há inúmeras lacunas em relação à assistência estudantil, no que se refere à permanência e êxito, e à sistematizaçáo da prática profissional do setor de atendimento ao estudante, tais como: - necessidade urgente de um trabalho mais ativo com a comunidade escolar, de forma a esclarecê-la de que a assistência estudantil consiste em uma política, e que, como tal, se refere a um direito, e não a uma mera tarefa da instituição em executá-la; aumento dos recursos na mesma proporçáo do crescimento da demanda pelo atendimento estudantil, e, em se tratando do Campus Várzea Grande, em um contexto que conta com um número reduzido de profissionais da equipe multiprofissional - sendo que atualmente o Campus de Várzea Grande possui mais de 800 estudantes em todas as modalidades de ensino, contando apenas com uma equipe multiprofissional composta por uma (1) assistente social, uma (1) psicóloga, uma (1) intérprete de Libras, um (1) técnico em assuntos educacionais e uma (1) pedagoga -, o que constitui um desafio para a execução da assistência ao estudante, pois os setores da instituição estão sobrecarregados.

A política de assistência estudantil por vezes é vista com restrição pelos profissionais da educação, e, na maioria das vezes, essas opinióes estão pautadas no entendimento de que a educação é uma política com base na meritocracia, e não de que é um direito instituído. Visualizou-se, contudo, avanços significativos nesse âmbito, como é o caso da aprovação da nova Política de Assistência Estudantil do IFMT, a qual está comprometida com a perspectiva universalizadora e em sintonia com as necessidades dos estudantes, que precisam ter conhecimento dos serviços ofertados.

Destaca-se, portanto, a importância de uma ampla divulgação, para a comunidade interna e a sociedade em geral, da política de assistência estudantil, dos programas, das açóes, dos recursos e dos critérios de acesso a 
ela no Campus Várzea Grande. A assistência estudantil, afinal, é um direito social que deve estar claro para a comunidade do Campus, objetivando a sua melhoria. Nesse sentido, o envolvimento dos estudantes é essencial para o planejamento e a avaliação da política, potencializando, inclusive, a dimensão político-pedagógica da prática profissional do Serviço Social escolar.

\section{Referências}

ARROYO, Miguel. Educação de jovens e adultos: um campo de direitos e de responsabilidade pública. In: SOARES, Leôncio; GIOVANETTI, M. A.; GOMES, N, L. (org.). Diálogos na educaçáo de jovens e adultos. Belo Horizonte: Autêntica, 2005.

BARBOSA, Eduardo Fernandes. MOURA, Dácio Guimarães. Metodologias ativas de aprendizagem na Educação Profissional e tecnológica. Boletim Técnico SENAC. Rio de Janeiro, v. 39, n. 2, p. 48-67, maio/ago. 2013.

BRASIL. Portaria Normativa MEC n.o 39, de 12 de dezembro de 2007, que institui o Programa Nacional de Assistência Estudantil. Brasília: 2007.

BRASIL. Constituição da República Federativa do Brasil: texto constitucional promulgada em 5 de outubro de 1988, com alteraçóes determinadas pelas Emendas Constitucionais de Revisão n. 1 a 6/94, pelas Emendas Constitucionais n. 1/92 a 91/2016 e pelo Decreto Legislativo n. 186/2008. - Brasília: Senado Federal, Coordenação de Ediçóes Técnicas, 2016.

BRASIL. Decreto n. 5.840 de 13 de julho de 2006, que institui, no âmbito federal, o Programa Nacional de Integração da Educação Profissional com a Educação Básica na Modalidade de Educação de Jovens e Adultos - Proeja, e dá outras providências.

BRASIL. Decreto n.o 7.234, de 19 de julho de 2010, que dispóe sobre o Programa Nacional de Assistência Estudantil. Brasília: 2010.

BRASIL. Lei no 12.852, de 5 de agosto de 2013. Institui o Estatuto da Juventude e dispóe sobre os direitos dos jovens, os princípios e diretrizes das políticas públicas de juventude e o Sistema Nacional de Juventude SINAJUVE. Brasília, 2013.

BRASIL. MEC. LDB - Lei no 9.394, de 20 de dezembro de 1996. Estabelece as Diretrizes e Bases da Educação Nacional. Brasília: MEC, 1996.

BRASIL. Ministério de Desenvolvimento Social e Combate à Fome. Orientaçóes Técnicas: Centro de Referência de Assistência Social - CRAS. Brasília: Ministério do Desenvolvimento Social e Combate à Fome, 2009. 
BRASIL. PROEJA-Programa de Integração da Educação Profissional com a Educaçáo Básica na modalidade de Educação de Jovens e Adultos. Documento Base. Brasília: 2007.

CISLAGHI, Juliana Fiúza; SILVA, Matheus Thomaz da. Plano Nacional de Assistência Estudantil e a Expansão de Vagas nas Universidades Federais: Abrindo o debate. V ENCONTRO BASILEIRO DE EDUCAÇÃO E MARXISMO. MARXISMO, EDUCAÇÃO E EMANCIPAÇÃO HUMANA. In: Anais... abril de 2011, UFSC. Florianópolis, 2011.

CONSELHO FEDERAL DE SERVIÇO SOCIAL. Conselho Federal de Serviço Social GT de Educação - Subsídios para o Debate sobre o Serviço Social na Educação. Brasília, 2011.

DOMANSKI, Letícia. O aprendizado de línguas no Proeja Vendas: contribuições na e para a vida dos educandos. 2016. Dissertação (Mestrado em Educação nas Ciências). Universidade Regional do Noroeste do Estado do Rio Grande do Sul. Ijuí, RS, 2016.

FREIRE, Paulo. A educação na cidade. 7. ed. São Paulo: Cortez, 2006.

FREIRE, Paulo. Educação como prática da liberdade. 14. ed. Rio de Janeiro: Paz e Terra, 2011.

IFMT. Projeto Pedagógico do Curso Técnico em Serviços de Condomínio - PPC/Proeja. Várzea grande/MT: IFMT, 2014.

IFMT. Resolução n. 094, de 18 de outubro de 2017. Política de Assistência Estudantil do Instituto Federal de Educaçáo, Ciência e Tecnologia de Mato Grosso. 2017.

IFMT. Resolução n. 095, de 18 de outubro de 2017. Regulamento Geral da Política de Assistência Estudantil do Instituto Federal de Educaçáo, Ciência e Tecnologia de Mato Grosso. 2017.

LEMOS, Suely Fernandes Coelho; CARMO, Gerson Tavares do. A Criação do Núcleo de Estudos sobre Acesso e Permanência na Educação - Contextos Cronológicos e de Implantação Institucional. In: CARMO, Gerson Tavares do (org.). Sentidos da permanência na educação: o anúncio de uma construção coletiva. Rio de Janeiro: Tempo Brasileiro, 2016.

NORO, Margarete Maria Chiapinotto. Gestão de Processos no Proeja: razão de acesso e permanência. 2011. Dissertação (Mestrado em Educação). Faculdade de Educação, Universidade Federal do Rio Grande do Sul. Porto Alegre, RS, 2011. 
OLIVEIRA, Fátima. Ser negro no Brasil: alcances e limites. Estudos Avançados. São Paulo, v. 18, n. 50, 2004.

PEREIRA, Josué Vidal. O Proeja no Instituto Federal de Goiás - Campus Goiânia: um estudo sobre os fatores de acesso e permanência na escola. 2011 . Dissertação (Mestrado em Educação). Faculdade de Educação, Universidade de Brasília. Brasília, 2011.

SOUZA, Jacqueline Domiense Almeida de. Na travessia: assistência estudantil da educação profissional. As interfaces das políticas de assistência social e educação. 2017. 190 f. Dissertação (Mestrado em Políticas Públicas). Universidade de Brasília, Brasília, 2017.

TAUFICK, Ana Luiza de Oliveira Lima. Avaliação da Política de Assistência Estudantil dos Institutos Federais para o Proeja. 2013. Dissertaçáo (Mestrado em Gestão e Avaliação da Educação Pública). Centro de Políticas Públicas e Avaliação da Educação da Universidade Federal de Juiz de Fora. Juiz de Fora, MG, 2013.

\section{Entrevistas}

ESTUDANTE 1. Entrevista concedida a Carminha Aparecida Visquetti. Várzea Grande, 25/05/2016.

ESTUDANTE 3. Entrevista concedida a Carminha Aparecida Visquetti. Várzea Grande, 13/03/2016.

ESTUDANTE 4. Entrevista concedida a Carminha Aparecida Visquetti. Várzea Grande, 06/12/2016.

ESTUDANTE 6. Entrevista concedida a Carminha Aparecida Visquetti. Várzea Grande, 01/12/2016.

ESTUDANTE 7. Entrevista concedida a Carminha Aparecida Visquetti. Várzea Grande, 05/12/2016.

ESTUDANTE 8. Entrevista concedida a Carminha Aparecida Visquetti. Várzea Grande, 06/12/2016.

ESTUDANTE 9. Entrevista concedida a Carminha Aparecida Visquetti. Várzea Grande, 12/12/2016.

ESTUDANTE 10. Entrevista concedida a Carminha Aparecida Visquetti. Várzea Grande, 1/12/2016.

ESTUDANTE 11. Entrevista concedida a Carminha Aparecida Visquetti. Várzea Grande, 18/12/2017. 


\section{Grupo Focal}

ESTUDANTE 1. Grupo Focal concedido a Carminha Aparecida Visquetti. Várzea Grande, 12/12/2017.

ESTUDANTE 2. Grupo focal concedido a Carminha Aparecida Visquetti. Várzea Grande, 12/12/2017.

ESTUDANTE 4. Grupo focal concedido a Carminha Aparecida Visquetti. Várzea Grande, 12/12/2017. 


\title{
IDENTIDADES DOS SUJEITOS LEITORES DA EJA: CLARICE LISPECTOR E A VOZ DOS NEOLEITORES
}

\author{
Antônia Lúcia de Queiroz Tenório \\ Rosemar Eurico Coenga
}

\section{Introdução}

Qualquer que seja o gênero literário, este sempre exercerá no ser humano um importante papel psicológico para o processo de humanização. O desfrute de uma obra literária preenche a carência de fantasia, imaginação, criatividade, ficção e criação, elementos essenciais para o desenvolvimento psíquico e emocional de jovens e adultos, necessitando, assim, ter seu espaço nas aulas de leitura, pois, a formaçáo leitora da criança é táo importante quanto dar continuidade a esse processo ao neoleitor jovem e adulto.

As dificuldades relacionadas à literatura aumentam mais ainda quando se trata da Educação de Jovens e Adultos, doravante EJA, pois não são consideradas as especificidades do alunado desse modelo de ensino, muitas vezes recém-alfabetizado ou que se afastou da escola por muito tempo, por diversos motivos e que, portanto, ainda está no início da sua jornada de leitor. Esse tipo de leitor, Almeida (2008) definiu como "neoleitor".

Diante disso, tentávamos aplicar uma ou outra sequência didática o que também não mostrava resultado positivo, percebemos então que só isso não bastava, era preciso aliar nossas experiências e práticas a embasamentos teóricos, pois o ofício do professor engloba convergentemente as dimensóes prática e teórica. Assim, a inevitabilidade de maior fundamentação teórica para amparar nossa prática docente cada vez mais aumentava, impulsionando-nos a pesquisar sobre a formação literária de jovens e adultos no Ensino Médio. Problema detectado, então era hora de partir para a pesquisa orientada, ou seja, era preciso voltar aos estudos, por isso, ingressamos no mestrado.

A partir desse panorama que esta pesquisa foi concebida. Assim, partimos do princípio de que o ensino de leitura, tal como é concebido nas aulas de Língua Portuguesa na EJA pouco ou quase nunca estimula o hábito de ler, muito menos é capaz de produzir leitor literário. Diante dessa inquietude pedagógica e da percepçáo da importância da formação destes leitores jovens e adultos, nasceu a necessidade de partir para novos caminhos, na busca de alternativas metodológicas eficazes para trabalhar com a leitura. 
Assim, considerando a problematização exposta, esta pesquisa busca responder as seguintes questóes: como minimizar o distanciamento do leitor com a leitura literária? Quais perspectivas são fundamentais para ampliar o letramento literário de jovens e adultos? Que modificaçóes esses momentos geraram na prática pedagógica dessa pesquisadora? E na interpretação/ recepçáo dos contos lidos?

Assim, esta pesquisa se justifica pela necessidade de proporcionar a esses educandos da EJA, muitos deles ainda neoleitores, a possibilidade de aquisiçáo de leitura de forma prazerosa e sistematizada, promovendo uma prática constante de leitura de variados textos e com uma literatura que considere, acima de tudo, o leitor principiante, permitindo-lhe compreender melhor o seu mundo. Objetiva também uma maior proficiência em leitura literária, como também fortalecer e desenvolver a capacidade leitora desses jovens e adultos, aplicando a sequência básica de leitura literária proposta por Rildo Cosson (2016).

Esta investigação teve como universo uma turma do ensino médio, do Centro deEducação de Jovens eAdultos Professor Antônio Cesário de Figueiredo Neto, no município de Cuiabá. A pesquisa teve um caráter predominantemente qualitativo, adotando um arcabouço metodológico descritivo para trilhar os caminhos da pesquisa de campo, por meio da pesquisa-ação.

A pesquisa teve como contribuiçáo teórica as concepçóes de autores que abordam leitura e letramento: Magda Soares (1999, 2003), Ângela Kleiman (2012); letramento literário: Rosemar Coenga (2010), Coenga e Fabiano Grazioli (2014), Graça Paulino et al. (200), Paulino e Cosson (2009), Rildo Cosson $(2014$, 2016) e sobre o neoleitor: Geraldo Peçanha de Almeida (2008), Carmem Lúcia Eiterer e Juliana Abreu (2009), Elisiani Tiepolo (2009, 2010).

Além disso, a pesquisa contou com os procedimentos metodológicos da sequência básica de Cosson (2014) em uma oficina, a partir do gênero conto com enfoque nas questóes do gênero mulher. Propomos para a oficina de leitura literária quatro contos da obra $A$ via crucis do corpo, de Clarice Lispector (1998).

Ao longo do nosso trabalho como professora/pesquisadora procurávamos caminhos para facilitar as múltiplas açóes e aproximaçóes com a leitura literária, um percurso que acreditávamos ser relevante não só para nós quanto para eles, mas também para todos aqueles que estivessem vivenciando os mesmos papéis.

Nesse sentido, as questóes das quais tratam este trabalho estão direcionadas ao nosso desejo de contribuir para o trabalho de professores da EJA, geralmente 
temas pouco discutidos pelos teóricos sobre leitura e também pelas pesquisas em estudos literários.

Esperamos que esta investigação possa contribuir para o desenvolvimento da capacidade leitora do neoleitor, minimizando o distanciamento entre o leitor e a leitura. Almejamos também que a metodologia de leitura literária aqui aplicada auxilie não só nossa prática pedagógica, como também dos demais professores de Língua Portuguesa que atuam no ensino médio da EJA.

\section{Neoleitor e a leitura}

Antes de apresentarmos os conceitos de neoleitor definidos por Almeida (2008) e Tiepolo (2009, 2010), faz-se necessário explicitarmos as condiçóes que os determinam. Para isso, analisaremos alguns dados do Indicador de Alfabetismo Funcional, doravante INAF.

O resultado de uma pesquisa do INAF, tendo como critério população brasileira entre 15 e 64 anos, intitulada "Estudo especial sobre alfabetismo e mundo do trabalho (2016)" aponta que quase $92 \%$ do universo pesquisado está abaixo do nível proficiente de alfabetismo, ou seja, esse percentual da população brasileira não possui competência em escrita e leitura, nem habilidades matemáticas. Esses dados do INAF comprovam o expressivo crescimento de um novo segmento de leitores, os neoleitores. (AÇÃO EDUCATIVA, 2016).

Para Tiepolo (2010, p.7) “[...] os neoleitores se caracterizam por apresentarem níveis bastante variados de domínio da linguagem escrita, mas têm em comum o fato de estarem iniciando a constituição de um acervo de textos escritos, e terem pouca experiência de leitura sem a mediaçáo do outro (o alfabetizador)." Diz ainda que o neoleitor é aquele sujeito que passa por um processo de alfabetização baseado em memorizaçóes, levando-os a pensar que ler é decodificar.

Almeida (2008) definiu como neoleitor aqueles jovens e adultos que não tiveram boas experiências no percurso escolar, que ainda não foram capazes de adquirir a plena capacidade de ler um texto e fazer conexóes com outras leituras ou com suas experiências de vida, falta-lhes a capacidade de ordenar fatos, construir conceitos, analisar e discutir aspectos mais complicados, enfim, de pensar além do texto.

O conceito de neoleitor anteriormente expresso também é considerado por Tiepolo (2009), contudo, a autora acrescenta que além das questóes ligadas ao campo da escrita e da leitura, outras peculiaridades podem ser descritas 
ao definir o perfil desse novo tipo de leitor. A autora enfatiza que o neoleitor possui algumas peculiaridades, como: vínculo com o mundo real, mesmo morando em área urbana; sobrevive em subempregos, percebendo baixos salários; idosos em busca de instruçáo e mulheres motivadas a auxiliarem os filhos nos deveres escolares. Completa ainda que:

São pessoas que foram sendo deixadas à margem da escola, mas continuaram criando seus filhos e, mesmo sem saber ler e escrever, lhes deram um nome, registraram, matricularam na escola e fazem o que podem inclusive voltar a estudar, para que eles não repitam sua história de fracasso escolar. (TIEPOLO, 2009, p. 128).

Tiepolo considera que o neoleitor, ainda que não faça muito uso de suportes escritos, tem contato diário com esses materiais. Além disso, esse novo tipo de leitor possui, vinculados ao seu cotidiano e ao seu trabalho, vasto conhecimento de mundo e rica experiência de vida. Por isso, as experiências e vivências do neoleitor devem ser valorizadas, assim como os conhecimentos de uma criança são considerados.

\section{Políticas de leitura para neoleitores no Brasil}

Tiepolo (2009, p. 129) considera muito importante as políticas de leitura voltadas para o neoleitor já implementadas, entretanto, acredita que apenas um grande acervo de bons livros não basta para promover a leitura, pois “[...] Se assim fosse, já teríamos avançado muito em termos de formaçáo de leitores, tendo em vista os diversos programas de distribuição de livro - bons livros pelos quais eles chegam, mas a leitura não."

Diante disso, a autora afirma que além da valorosa elaboração de obras literárias inéditas específicas para o público neoleitor, há ainda o desafio de oportunizar o encontro dessas obras com o neoleitor para que sejam conhecidas pela comunidade escolar e que, principalmente, o professor seja o seu primeiro leitor.

Tiepolo (2009, p. 130) aponta alguns caminhos para vencer tais desafios. Primeiramente há que se pensar na maneira como o livro é divulgado, ou indicado, pois isso incidirá diretamente na relaçáo deste com o neoleitor, assim, é imperioso que o professor crie "[...] situaçóes em que a motivação é o desejo, e não a obrigação, ou a curiosidade, e não a burocracia. E se na vida do leitor ter um livro nas máos significa uma conquista, na escola isso pode significar mais uma tarefa imposta a ser cumprida." 
Isso quer dizer que atribuir um caráter de imposição, obrigatoriedade e burocracias à leitura literária só contribuirá para a desmotivação ou até mesmo aversão ao ato de ler, por isso, cabe ao professor estimular positivamente o encontro do neoleitor com uma obra literária, despertando-lhe o desejo e a curiosidade, mas para isso "[...] há que se pensar uma formação continuada de educadores/leitores, sem o que os livros continuarão a servir apenas àqueles que já são leitores." (TIEPOLO, 2009, p.130).

\section{Pressupostos da leitura literária}

Leffa (1999) apresenta um estudo aprofundado de diferentes linhas teóricas que tratam do elemento intelectivo e social da leitura. O autor classifica essas teorias em três grandes grupos: ascendentes, descendentes e conciliadoras. As teorias ascendentes têm foco no texto, assim, a leitura é compreendida como "[...] como um processo de extração dos sentidos do texto." O grupo das teorias descendentes aponta como centro da leitura o leitor, pois é ele quem atribui sentidos ao texto, ou seja, o ato de ler depende, principalmente, do leitor. As abordagens conciliadoras aliam o texto ao leitor e compreendem a leitura como "[...] um processo interativo/transacional, com ênfase na relação com o outro." (LEFFA, 1999, p. 13-15).

Cosson (2016) argumenta que as duas primeiras teorias de leitura apresentadas anteriormente são passíveis de críticas. As teorias da leitura que têm como foco o texto são criticadas porque ler é muito mais que decodificar letras, palavras e entender o seu significado. Já as teorias que têm como foco o leitor, embora considere uma teoria bastante positiva porque chama atenção para o ato de ler, entretanto se perde quando náo considera seus resultados.

As teorias que compóem o terceiro grupo, também chamadas de teorias de abordagem conciliatórias, são aquelas que atribuem igual importância tanto para o leitor, quanto para o texto, tendo a leitura como resultado de interação. Cosson (2016, p. 40) define leitura nas teorias conciliatórias como "[...] um diálogo entre autor e leitor mediado pelo texto, que é construído por ambos nesse processo de interação.” Diante disso, o autor conceitua leitura como "[...] um diálogo entre autor e leitor mediado pelo texto, que é construído por ambos nesse processo de interação." Entende também que ela é mais do que a aquisição de uma habilidade, 
"são práticas sociais que medeiam e transformam as relaçôes humanas", para isso, o pesquisador apresenta duas possibilidades de sistematizaçáo para o desenvolvimento de leitura literária: a sequência básica e sequência expandida. (COSSON, 2016, p. 40)

A sequência básica é essencialmente composta por quatro momentos: motivação, introdução, leitura e interpretação. O primeiro passo dessa sequência é a Motivaçáo, a qual consiste na preparação do aluno para que se entusiasme pela leitura e se envolva com o assunto, ou seja, tratase de uma antecipação do tema antes de penetrar no texto propriamente dito. (COSSON, 2016).

A Introdução é o momento de apresentar a relevância da obra, o porquê da sua escolha, mostrar o livro, destacando outros elementos que o introduzem como a capa, o prefácio, a contracapa, enfim, tudo que estiver relacionado ao suporte da obra. Além disso, é preciso fornecer algumas informaçóes básicas sobre o autor (COSSON, 2016).

A terceira fase, Leitura, é o momento de introduzir a obra e objetiva desenvolver habilidades de leitura do texto literário. Nesta etapa professor pode negociar o tempo e acompanhar a leitura de seus alunos para observar possíveis dificuldades relacionadas ao vocabulário e até mesmo à compreensão. A leitura pode ser compartilhada ou realizada pelo professor, tendo como propósito suscitar comentários dos alunos, provocar discussóes, expor opiniốes, compreender a contemporaneidade do tema retratado, bem como estimular a utilizaçáo do diário de leituras (COSSON, 2016).

Já a última fase, Interpretação, é o momento de construção dos sentidos em um diálogo que envolve o leitor, partindo de seu conhecimento de mundo, por intermédio de conclusóes que incluem o leitor, o autor e o grupo. Cosson (2016) aponta que o mais importante na interpretação é que o aluno tenha a chance de se manifestar sobre a obra lida e consiga relacioná-la a fatos de sua vida, de forma concisa, possibilitando a comunicação entre os leitores do grupo escolar.

Por isso, a leitura de textos literários é considerada por Cosson (2016) como uma atividade de grande importância para a formação do leitor. Além disso, o autor argumenta que na escola, a leitura literária deve ser avaliada como um recurso que permite ao aluno o acesso a um universo não só real, como também ficcional, uma vez que a literatura permite essa projeçáo para a realidade experienciada ao ler uma obra, transformando-o em protagonista ou náo na imaginação. 


\section{Metodologia de investigação e análise dos dados}

Esta investigação desenvolveu um estudo de caráter qualitativo o que, segundo Bauer e Gaskell (2012) implica um contato direto com os sujeitos da pesquisa e suas histórias. A produção dos dados envolveu a realidade de uma turma do ensino médio do Centro de Educação de Jovens e Adultos Professor Antônio Cesário de Figueiredo Neto, composta por 35 alunos e encontra-se localizada na cidade de Cuiabá.

Escolhemos trilhar pelos caminhos da pesquisa de campo, por meio da pesquisa-ação, que além de envolver assuntos teóricos, visa a intervenção do pesquisador na situação investigada, com o intuito de alterá-la e transformála. Assim, o trajeto metodológico percorrido nesta pesquisa teve o apoio das concepçóes de Thiollent (1986), pois segundo o autor:

[...] a pesquisa-ação é um tipo de pesquisa social com base empírica que é concebida e realizada em estreita associação com uma ação ou com a resolução de um problema coletivo e no qual os pesquisadores e os participantes representativos da situaçáo ou do problema estáo envolvidos de modo cooperativo e participativo. (THIOLLENT 1986, p. 14).

Depois da obtenção dos dados por meio de questionário, observação da oficina e entrevista com seis alunos, as informaçóes foram sistematizadas e analisadas. A análise e interpretação desses dados qualitativos foram articulados com as teorias e métodos de leitura discutidos na fundamentação teórica.

Além disso, a Sequência Básica de Rildo Cosson (2016) serviu de suporte para as oficinas de leitura literária. As oficinas ocorreram no período de 19 de junho a 07 de julho de 2017, foram seis encontros de três horas, perfazendo um total de dezoito horas.

É importante destacar que a análise dos questionários, logo a seguir, evidenciará dados quantitativos em diálogo com os qualitativos, entretanto, são os elementos qualitativos que sobressairão.

A análise por amostragem nos revelou que $70 \%$ da turma era composta por alunos de 18 a 20 anos de idade, demonstrando que os estudantes são majoritariamente jovens. Pesquisas já apontam o crescente número de jovens que migram para a EJA, dentre esses estudos podemos destacar o livro Jovens cada vez mais jovens na educaçáo de jovens e adultos, de Carmen Brunel (2004). 


\section{Idade}

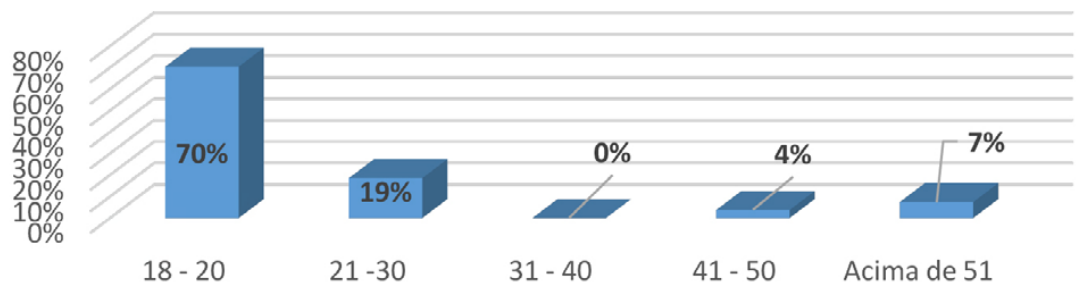

Fonte: As autoras.

A autora analisa a ocorrência da chegada de estudantes cada vez mais jovens na EJA, apontando os fatores que contribuem para esse crescimento. Brunel (2004) atribui esse aumento a fatores como histórico de fracasso em decorrência de repetência na mesma série por vários anos, evasão, desmotivação e desencanto com o sistema regular de ensino, somando-se a isso, há casos também de desigualdades sociais que os obrigam a se inserirem desde muito cedo no mundo do trabalho, roubando-lhes o tempo do ambiente escolar e da infância.

A presença de livros em casa é uma particularidade que evidencia a aproximação dos alunos com a cultura escrita, por isso, perguntamos que tipos e suportes de leitura circulam na casa deles. Os livros literários só ficaram à frente dos livros técnicos. Os religiosos e revistas ficaram empatados em primeiro lugar e os livros didáticos alcançaram a segunda posição. Além disso, importante observar que, embora dito que gostam de leitura, apenas $22 \%$ anunciaram frequentar a biblioteca.

Figura 2 - Tipos e suportes de leitura que circulam em casa.

\section{Que tipos e suportes de leitura que circulam em casa?}

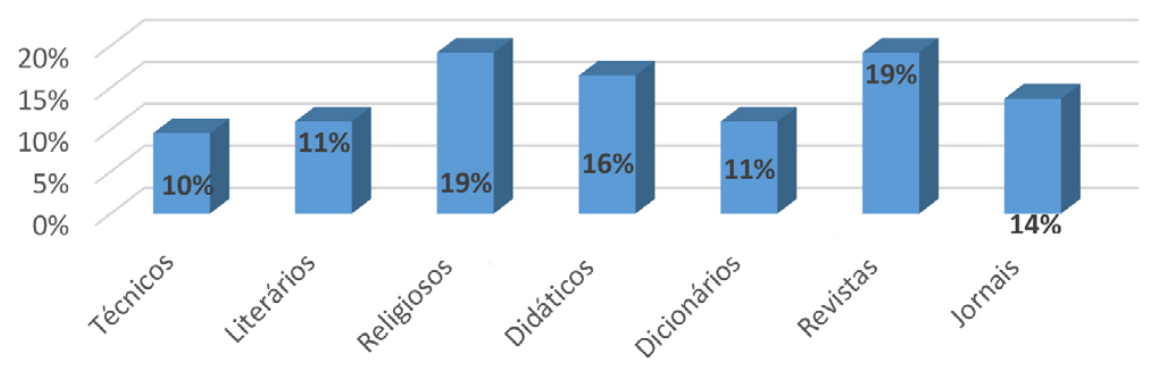

Fonte: As autoras. 
Com isso, podemos notar que a biblioteca não se constitui em uma ferramenta importante capaz de atrair os alunos para frequentá-la, muito pelo contrário, o seu acervo de livros didáticos desestimula o hábito e o desejo pela leitura. Magda Soares (2003) pode colaborar na apreensão do que foi expresso anteriormente e ainda acrescenta outro problema: o número reduzido de bibliotecas, ou seja, "não lhes são dadas as condiçóes para ler e escrever: não há material impresso posto à disposição, não há livrarias, o preço dos livros e até dos jornais e revistas é inacessível, há um número muito pequeno de bibliotecas". (SOARES, 2003, p. 58).

Figura 3 - Frequências na biblioteca escolar.

\section{Você frequenta a biblioteca escolar?}

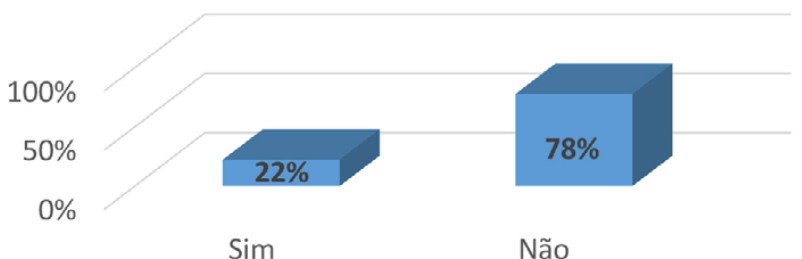

Fonte: As autoras.

Assim como Soares (2003), Eiterer e Abreu (2009, p. 155) também destacam que "[...] muitos dos problemas de leitura no Brasil são gerados pela falta de acesso a livros e material de leitura literária de qualidade, por seu alto custo e pela carência de espaços públicos de leitura. " Por isso, cabe à escola e aos professores disponibilizarem biblioteca com acervo literário incentivador como também, espaços para leitura na escola.

Além disso, Eiterer e Abreu (2009, p. 155) aponta que a má escolarização da leitura no modelo de ensino regular muitas vezes gera, entre a leitura literária e o leitor, resultados prejudiciais e de longa duração. As autoras destacam também que “[...] na EJA estes efeitos são ainda mais drásticos. A memória do sofrimento anterior é um obstáculo a mais, que mantém o aluno adulto longe deste objeto na sua volta para a escola."

Com relação ao motivo para ler, a maioria da turma respondeu que a principal motivação consistia em atualização cultural e exigência escolar, somente a minoria dos investigados revelou que lê por prazer ou necessidade espontânea. 
Motivação para ler um livro

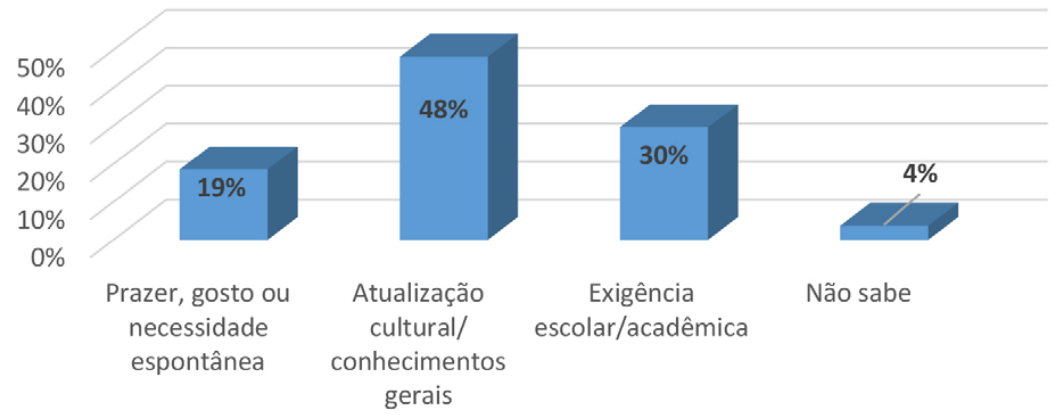

Fonte: As autoras.

$\mathrm{Na}$ categoria gênero de leitura que mais gostam, o romance foi o mais apontado, seguido de histórias em quadrinhos, aventura e o texto religioso quase em último lugar. Curioso observar também que quando perguntados sobre quais tipos e suportes de leitura circulam na casa deles, o texto religioso e revistas aparecem empatados em primeiro lugar, seguido dos textos didáticos, jornais e, quase em último lugar, os textos teatrais.

Figura 5 - Gênero que mais gosta.

De que gênero(s) você gosta?

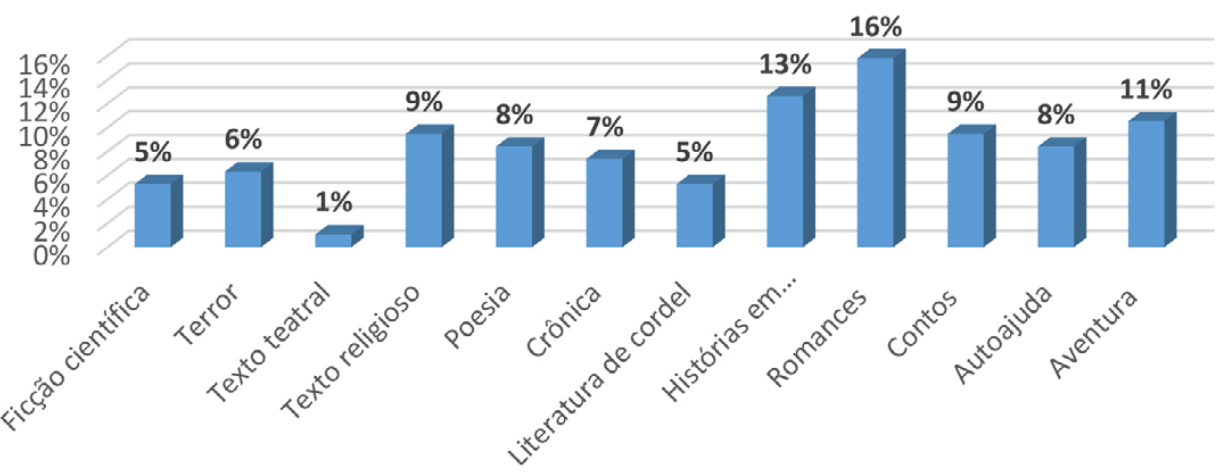

Fonte: As autoras.

Relativo às opçóes de leitura, as respostas para os itens: título do livro e indicação do professor foram bem equilibradas, alcançando, respectivamente, $33 \%$ e $30 \%$ contra $22 \%$ para indicação de amigos e $15 \%$ pelo autor. 
Os dados expostos nos revelam que o docente ainda continua sendo quem mais sugere leitura aos alunos, o que confere a ele, cada vez mais, o comprometimento de atualizar sua prática pedagógica e se qualificar continuamente. Além disso, deve ser um profissional muito bem informado, criativo, dinâmico e, sobretudo, ser efetivamente um leitor para indicar a leitura por meio do seu exemplo prático de leitor.

\section{Figura 6 - Escolha de leitura.}

\section{Como escolhe o que vai ler?}

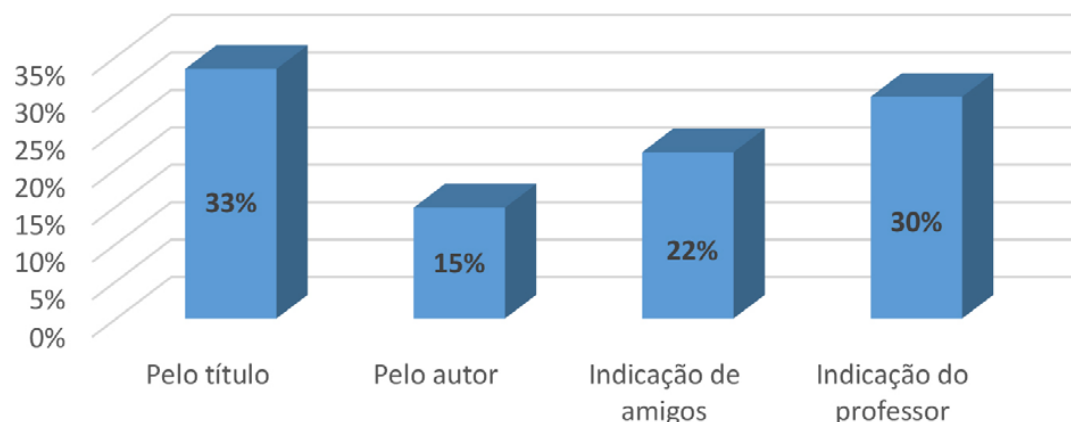

Fonte: As autoras.

Silva (1999), Paulino et al. (2000), Coenga (2010) e Cosson (2016) compartilham do mesmo pensamento em relação a importante função do educador como instigador e mediador de leitura. Para que isso ocorra, destacam a importância da formação docente. Mas não só isso, os autores destacam também que além da formação dos docentes, estes devem ter uma boa convivência com a literatura, devem ser leitores de fato para que possam influenciar na escolha do livro literário e acima de tudo trabalhá-lo adequadamente em sala.

Avaliamos que os dados produzidos nos possibilitaram uma aproximação maior com os educandos e também nos permitiu escolher e sistematizar adequadamente procedimentos de leitura literária. A partir da análise dos gráficos expostos neste texto, podemos concluir que as questóes respondidas demonstraram um perfil de alunos com pouca leitura e pouca familiaridade com o gênero conto, tendo o professor como um dos principais influenciadores de leitura.

A partir dessas informaçóes, foi possível definir algumas diretrizes para a oficina de leitura literária. Sendo a escola um ambiente que pode influenciar a escolha e incentivar cada vez mais os alunos, justificamos a proposta de uma 
sequência didática interventiva, com foco na leitura desse gênero. A sequência de atividades foi elaborada levando em consideração as respostas dadas, principalmente no que diz respeito ao universo de expectativa dos alunos.

\section{Oficinas de leitura}

As oficinas de leitura desenvolvidas tiveram como suporte metodológico a Sequência Básica de Rildo Cosson (2014) a partir do gênero conto com foco nas questóes do gênero mulher. Propomos para a oficina de leitura literária quatro contos em $A$ língua do $p$, Ruido de passos, mas vai chover e $O$ corpo, da obra $A$ via crucis do corpo, de Clarice Lispector (1998), pois o tema aborda a questão do corpo como graça e maldição, representado pela condição feminina e seus desejos.

O primeiro conto lido foi $A$ língua do $\mathrm{p}$, a narrativa trata das várias questóes relacionadas à sexualidade feminina, porém tendo como fio condutor a violência sexual contra a mulher. Após a leitura, foram instruídos a registrar de forma escrita as impressóes que obtiveram com a narrativa, relacionadas às emoçóes e aos sentimentos que aquela leitura lhes proporcionou.

Dentre as impressóes que tiveram, destacamos algumas mais relevantes: surpresa, pela esperteza de Cidinha se livrar dos estupradores; nojo e muita raiva, vontade chorar porque me lembrei de ter passado por uma situação parecida; medo de andar de ônibus, hoje a violência está cada vez maior, principalmente em relação à mulher; alegria porque a professora conseguiu se livrar dos dois homens, mas ao mesmo tempo tristeza pela outra mulher; nojo de homens que usam a força para abusar de mulheres indefesas, porque se ela fosse forte ou estivesse armada eles não tentariam isso.

Destacamos aqui que essas impressóes que os alunos tiveram diante da leitura do texto reforça a concepção de Cosson (2016) sobre literatura.
A literatura nos diz o que somos e nos incentiva a desejar e a expressar o mundo por nós mesmo. E isso se dá porque a literatura é uma experiência a ser realizada. É mais que um conhecimento a ser reelaborado, ela é a incorporação do outro em mim sem renúncia da minha própria identi- dade. [...] A experiência literária não só nos permite saber da vida por meio da experiência do outro, como também vivenciar essa experiência. (COSSON, 2016, p. 17).

Constatamos que quando expressaram os sentimentos de raiva, nojo, tristeza, medo e vontade de chorar ao ler o conto, eles viveram uma experiência literária, proporcionada pela a incorporação da vivência do outro na vida neles.

Com o intento de promover maior apreensão do conto, fizemos duas 
perguntas: o que aprenderam com a leitura do conto e se recomendariam a sua leitura. As questóes deveriam ser respondidas individualmente para posterior compartilhamento com a turma. Esta atividade escrita objetivava, dentre outras coisas, identificar e relacionar o texto literário à realidade, compreender a contemporaneidade do tema retratado, desenvolver habilidades de leitura do texto literário, expor opinióes e provocar discussóes.

Esta atividade permitiu o compartilhamento de suas expectativas, dúvidas e interpretaçóes. Nessa perspectiva, Cosson (2016, p. 27) nos diz que “[...] a leitura é um ato solitário, mas a interpretação é um ato solidário. " Assim, a relação entre contexto, leitura e interpretação - individual e coletiva - foi efetivada com o seu compartilhamento, acarretando maior desenvolvimento da leitura e, sobretudo, compreensão da obra.

Em Ruido de Passos, Clarice Lispector expóe a angústia da personagem Cândida Raposo, uma idosa viúva que aos oitenta e um anos se desespera ao perceber que ainda sente desejo sexual. O desespero é tanto que ela pensa vivenciar um fenômeno patológico e vai à busca de um médico para resolver sua doença, pois, para ela, à mulher de mais idade não se admite a possibilidade de existência da sexualidade. A repressáo é tamanha que nem mesmo falar sobre desejo sexual é permitido, tanto que ela usa o termo "a coisa" para se referir ao sexo.

Mas vai chover conta a história de uma senhora idosa viúva e rica chamada Maria Angélica de Andrade. A personagem corresponde ao rótulo de uma mulher idosa que possivelmente não sentiria mais prazer, nem desejo pelo sexo, devendo apenas cuidar dos netos e esperar pela morte. Entretanto, ela rompe com esse modelo e mostra, destemidamente, a todos o seu desejo sexual ao pagar Alexandre pelo relacionamento sexual. Essa conduta dela socialmente inusitada indica que não existe razão para que uma mulher idosa não sinta prazer e não tenha uma vida sexual ativa.

Com esses dois contos, Clarice Lispector, ainda no ano de 1974, ano da primeira edição da Via Crucis, nos provoca a refletir sobre sexualidade da mulher na terceira idade. Nos contos: Ruidos de passos e Mas vai chover, ela traz à tona algo proibido para as mulheres consideradas honestas: desejo sexual. A censura consistia em sentir, falar ou pagar pelo prazer. Com os dois contos a autora nos mostra que nossa cultura náo aceita muito a possibilidade do desejo sexual na terceira idade.

Percebemos que o desejo sexual das mulheres da terceira idade é alvo de preconceito, pois considera-se objeto de desejo sexual os corpos jovens e bonitos. Nesse sentido, para a sociedade, um corpo murcho, flácido e enrugado traz a marca de uma mulher idosa e isso náo deve despertar o desejo 
em ninguém. A mulher com essa idade deve pensar em qualquer outra coisa, menos sexo. Dessa forma, Clarice Lispector trata a questáo da sexualidade da mulher da terceira idade nos contos: Ruidos de passos e Mas vai chover, como uma condiçáo inseparável do ser humano, pois o desejo e o prazer continuam vivos também no universo da mulher idosa, não se trata de uma exclusividade só de homens e jovens.

O último conto, $O$ corpo, aborda um triângulo amoroso bem estável entre Xavier, Beatriz e Carmem. Os três vivem juntos na mesma casa mantendo entre eles um relacionamento amoroso duradouro. Contudo, Xavier não satisfeito com as duas mulheres resolve traí-las com uma prostituta. Quando elas descobrem a traição, o triângulo se desestabiliza, então, a partir desse acontecimento, as duas se afastam dele e se aproximam cada vez mais e passam a cogitar uma vingança contra Xavier. Assim fizeram. Executaram Xavier e o enterraram no jardim.

O Corpo aborda vários tabus presentes na nossa sociedade: poliamor, traição, prostituição e assassinato, contudo foi possível perceber que a maioria dos alunos esboçou uma reaçáo tranquila com relaçáo ao texto, embora tenham dito que náo apostariam em um relacionamento nesses moldes, respeitam os que optaram por essa forma de amar.

Ao longo dos encontros, preocupávamos sempre com a realização na prática em sala de aula, de que o desejo que as experiências dos participantes com os contos fossem realmente significativas e produtivas, não apenas enquanto alunos em práticas de letramento, mas enquanto sujeitos, numa visão humanizadora e integral. Objetivamos em nossa proposta privilegiar a própria experiência que nos passa enquanto lemos e, por isso, pudessem nos formar, transformar ou deformar, conforme propóe o educador Larossa (2002).

\section{O que dizem as entrevistas}

Como já observamos na análise dos questionários anteriormente, a EJA apresenta, em uma mesma turma, perfil bastante heterogêneo tanto relacionado à idade, profissáo, condiçóes econômicas ou até mesmo aspiraçôes para o futuro. Foi possível constatar que a opção pela EJA representa a oportunidade de concluir o ensino médio de maneira mais rápida, visando ingressar em um curso superior, como também uma forma de ascender profissionalmente.

Dois pontos chamaram bastante atençáo em relaçáo ao que esperavam encontrar na EJA e se essa expectativa foi alcançada. Primeiro, a questão da 
crença que a EJA se destina a pessoas analfabetas e limitadas. Na concepçáo de um dos alunos:

Sinceramente, não esperava encontrar muita coisa, né? Porque todo mundo comenta: ah! É muito limitado, não tem muita coisa, é melhor tu fazer, se é pra fazer mais rápido, vai fazer pago que você termina em seis meses, aí eu disse: não! Tenho que ir lá, sentar na sala e ver, e superou as minhas expectativas (A1).

O relato do aluno serviu para exemplificar que a EJA é tratada com certa discriminação pela sociedade, como se a sua clientela fosse formada, apenas, por alunos com problemas cognitivos que os limitariam a aprender até determinada idade, atribuindo à EJA o papel de redenção. Essa temática é discutida por Di Pierro (2008) ao afirmar que:

[...] o analfabetismo e a baixa escolaridade estáo associados a outros processos de exclusão social - pobreza, vivência rural, condição feminina, pertencimento a grupos étnicoculturais discriminados, baixa qualificaçáo profissional e situação desvantajosa no mercado de trabalho. (DI PIERRO, 2008, p. 397).

Para Di Pierro (2008), os sujeitos da EJA são vistos como alguém que não corresponde às exigências sociais nem tem as habilidades mínimas para desempenhar o jogo social, por isso, muitas vezes alvo de preconceito.

Outro ponto recorrente observado nesta questão, principalmente para os dois entrevistados idosos, diz respeito ao medo de encontrar dificuldades nesse processo de volta aos estudos. Possivelmente há resquícios de situaçóes relacionadas ao desempenho escolar deles, marcados pelo fracasso e insucesso na escola. É possível também que essas situaçóes façam com que a autoestima seja baixa, o que acarreta certa insegurança e muito medo de retornar.

Com relação aos hábitos de leitura, os resultados obtidos com as entrevistas nos revelam que todos os entrevistados reconhecem a leitura como algo muito importante para a obtenção de conhecimento e, além disso, acrescentam que a leitura é importante para "[...] ter uma comunicação e diálogo melhor com outras pessoas." (A1). Assim como o referido aluno, Coenga (2014, p. 191) também partilha do mesmo entendimento, ressaltando que "[...] a leitura é uma experiência que envolve a troca, o diálogo e a interação.”

Os entrevistados são conscientes de que o ato de ler representa uma importante função social, como também uma ferramenta de formação e transformação da sociedade, tendo como justificativa dessa importância a 
obtenção de conhecimento e socialização. Por isso, o professor tem aqui a tarefa de formar esse leitor, mostrando a ele que esse processo não pode cessar quando o percurso escolar for concluído, pois trata-se de uma formação para a vida.

Os resultados obtidos também nos revelam que boa parte dos alunos demonstram pouco interesse pela leitura literária, entretanto, não podemos deixar de ressaltar que ainda existem alunos que costumam procurar os livros não apenas como obrigação, mas como um meio de lazer, conforme trechos das entrevistas abaixo:

Os livros que eu leio são muito voltados a minha área profissional, que é a área da dança. Leio muitos livros de dança, muito livro de.... Assim, náo sei se entra como literatura, eu leio muitos livros de Chico Xavier, mais para o campo espiritual (A1).

Os dados obtidos revelam que os alunos não são leitores de textos literários, no entanto, salientamos que é arriscado afirmar que não leem nada. Ainda que não sejam leituras habituais e, mesmo que sejam determinadas pelo professor, as leituras ocorrem sim. Daí decorre a importância de mais incentivo aos alunos desde cedo para obterem o hábito da leitura literária e, acima de tudo, que essas leituras sejam sistematizadas para uma perfeita e adequada escolarizaçáo da literatura, como preconizam Soares (1999, 2003), Kleiman (2012), Paulino e Cosson (2009) e Cosson (2016).

Ao analisarmos a opinião dos alunos sobre os contos trabalhados em sala de aula e as impressóes sobre a leitura dos contos, foi possível perceber algumas funçóes que Cosson (2016) atribui à literatura. Um dos entrevistados avalia que:

Eu acho incrível. Eu, particularmente, não conhecia e quando você vai lendo, você mergulha e quando você vê, você já viveu aquela situação do conto, ou você já conheceu alguém que já passou por aquilo. É incrível, a autora é o máximo (A1).

Percebemos que o aluno avaliou a literatura como Cosson (2016, p. 17), pois, segundo o autor, "[...] a experiência literária não só nos permite saber da vida por meio da experiência do outro, como também vivenciar essa experiência."

Outro entrevistado enxerga a literatura de acordo com a seguinte perspectiva:

Muito interessante, eu estou gostando bastante. Assim, igual eu escrevi nas perguntas, cada um passa uma liçáo, uma lição assim que dá pra você ver que há muita realidade que é vivida e nem sempre é boa, mas já é uma lição que 
você leva, que você já leu, você já sabe como é, passando pela situação (A2).

Esse ponto de vista do aluno vai ao encontro do que pensa Cosson (2016, p. 17), pois ele considera a literatura como um experimento a ser realizado e que "[...] no exercício da literatura, podemos ser outros, podemos viver como os outros, podemos romper os limites do tempo e do espaço de nossa experiência e, ainda assim, sermos nós mesmos. "

A opiniáo dos alunos sobre as impressóes dos contos lidos nas oficinas mostrou-se bastante positiva, os contos foram bem recepcionados e, além disso, foi possível perceber a alegria e o entusiasmo expressos por alguns deles. Além do entusiasmo com o ato de ler, percebemos também a conexão que o aluno estabelece entre o conto e a vida dele ao dizer que náo condena um homem ter duas ou mais mulheres, contudo, quando se casar terá somente uma mulher, como comprovado no depoimento abaixo:

Eu achei legal, alguns contos diferentes, coisas que eu não tinha visto na escola ainda. $\mathrm{O}$ quê? Ah! Sobre tipos de amor e de relacionamento e também preconceito como no caso da idosa que namorava o rapaz de 19 anos. O preconceito das pessoas e do rapaz porque só ficava com ela pelo dinheiro. No caso do conto... aquele das duas mulheres e do homem, vemos muito hoje isso. Assim ... escancarado na vida real eu ainda năo vi, em livros de literatura também não, mas vejo em novelas, em filmes. Não tenho preconceito disso não, mas eu não faria o que o Xavier fez, porque quando eu me casar quero só uma mulher (A4).

Outros relatos expressos logo abaixo também revelam certo encantamento com os contos, evidenciando uma preferência maior pelo conto $O$ corpo. Essa preferência parece se dar por dois motivos: a autora ser a frente do seu tempo e a história ser atual.

Muito bom. Gostei de todos, mas o preferido foi O corpo. Porque achei bem pra frente a autora, parece que o conto foi escrito agora, nem parece que tem mais de 40 anos. Agora entendi porque disseram que era lixo, imagina um negócio desses naquela época? Bem doido, porque até hoje dá pra assustar (A6).

É o contemporâneo com o atual. O antigo com o digital. Assim, que vem o conto dos últimos que eu li, vem de anos e anos atrás e que naquela época não era tão visível 
como é agora. É incrível, quando eu soube a época que ele foi escrito, com a relação de hoje é incrível. Achei super atual (A1).

Relacionado a essa questáo da atualidade da obra, Cosson (2016) argumenta que a literatura na escola deve apresentar náo só o cânone, como também o contemporâneo para que se compreenda a pluralidade de leituras que o discurso literário articula. Além disso, o autor ainda completa que a escola, ao objetivar a formação literária de seus alunos, precisa apresentar sempre obras atuais, sendo elas contemporâneas ou não, pois, segundo ele, "[...] é essa atualidade que gera a facilidade e o interesse de leitura dos alunos." (COSSON, 2016, p. 34).

Mais um mote apontado, por um dos entrevistados, como o ponto mais interessante dos contos foi: "Os relatos de cada um de nós alunos." (A3). Cosson (2016) e Colomer (2007) também tratam dessa questão ao argumentarem que a melhor maneira de se formar leitores é o trabalho com a leitura compartilhada, ou seja, as interpretaçóes individuais dos alunos devem ser socializadas para que o grupo tenha a possibilidade de expandir os sentidos produzidos individualmente, julgando ser esse o ponto mais importante para construção de uma comunidade de leitores.

Possivelmente, assim como Cosson (2016) e Colomer (2007), o aluno percebeu que "[...] o que expressamos ao final da leitura de um livro náo sáo sentimentos, mas sim os sentidos do texto [...]" e quando socializados promovem a integração social e amplia visóes de mundo (COSSON, 2016, p. 28).

As avaliaçóes dos alunos sobre a oficina de leitura literária demonstraram que não conseguimos atingir a todos eles da forma que pretendíamos, entretanto, foi possível verificar que acendemos em alguns deles, no mínimo, uma fagulha de curiosidade e interesse pela leitura, conforme descrito a seguir.

Achei ótimo e eu acredito que é uma forma que deve continuar, sabe? Eu acho que tem que ser assim o trabalho, ter incentivo, não só para o jovem que está começando, mas sim, para jovens e adultos. Porque ler ajuda em todas as outras matérias que a gente aprende na escola (A3).

Eu achei legal, depois que começou dava até mais vontade de vim pra escola, eu esperava mais a segunda e a sexta feira pra continuar as leituras. Outra coisa boa é a gente treinar a leitura porque a gente nunca vai saber se gosta de alguma coisa sem experimentar, por exemplo, nunca vou saber se gosto de [...] se gosto de caviar se nunca comi. Me lembrei daquela música: 'nunca vi, nem comi, eu só ouço falar' (risos). Desse jeito é a leitura, não é mesmo? (A4). 
Evidenciamos no transcorrer desta pesquisa que o Aluno 4 demonstrou em táo curto tempo uma mudança positivamente significativa em relação à leitura, o que pode ser comprovado pelos próprios depoimentos, nos quais ele mesmo sinaliza os fatores que contribuíram para despertar seu interesse pela leitura.

O aluno acredita que, possivelmente, a mudança do seu ponto de vista relacionado à Língua Portuguesa tenha despertado nele o interesse pela leitura. Antes, não gostava da disciplina, entretanto, esse aspecto é modificado em consequência da metodologia aplicada nas aulas de leitura, momento em que começa a enxergá-la sob uma nova perspectiva.

Outro aspecto bastante interessante que observamos nesse aluno, refere-se à sua mudança de atitude durante o período das oficinas. Ele participou de todas as aulas, entretanto, não expressou nenhuma opiniáo oralmente até a terceira oficina.

Dias depois, ele nos relatou, no intervalo das aulas, que procurou na biblioteca da escola o livro "A via crucis do corpo", mas como já era de se esperar, não encontrou. Então decidiu procurar em uma biblioteca no centro da cidade e também não tinha disponível tal obra, mas tinha "Felicidade Clandestina" e como se tratava da mesma autora, decidiu tomá-lo emprestado e isso nos foi narrado com muito orgulho.

Cumpre salientar aqui, que se tratava de um aluno que não gostava das aulas de Língua Portuguesa, não se manifestava nas primeiras oficinas e, mais ainda, não tinha o hábito de ler, como comprovado na transcrição da entrevista logo abaixo:

Não diariamente, acho que mais depois que comecei a estudar aqui. Acho que eu me interessei mais um pouco e às vezes quando eu começava, eu não conseguia parar. As aulas me ajudaram um pouco também por quê ... na verdade não foi um livro, foram contos que lemos na oficina e os outros que lemos com a senhora antes da sua licença, não sei se isso conta. $\mathrm{O}$ único livro que eu li inteiro foi aquele da Felicidade Clandestina. Gosto também dos quadrinhos do Maurício de Souza e de mitologia grega (A4).

$\mathrm{Na}$ entrevista ele demonstra em várias oportunidades esse encantamento e orgulho por ter gostado de descobrir o prazer pela leitura. É fascinante constatar que foi despertada uma faísca nesse aluno, e essa centelha fez com que ele fosse em busca de algo que agora começa a lhe interessar. E esse encantamento que a leitura literária provoca no leitor ao final da leitura nada mais é que a manifestaçáo da expressão dos anseios e dos sentimentos humanos que Cosson (2016, p. 28) julga como "os sentidos do texto." 


\section{Considerações finais}

A formação de leitores vai muito além de um trabalho de dezoito horas em uma oficina de leitura literária. Obviamente o ideal não é iniciar esse processo no final da educação básica, contudo, a opção pela turma do ensino médio da EJA pretendia proporcionar a esses alunos algo que lhes foi negado no percurso escolar, a oportunidade de contato com a leitura literatura. Além disso, despertar neles o interesse pelo ato de ler de forma prazerosa, como também uma maior proficiência em leitura literária ao promover uma prática sistematizada e constante de leitura.

Nesse sentido, a pesquisa apontou caminhos para nossa inquietante busca de estratégias eficazes que contribuam para esse despertar para a leitura literária. Mostrou que os dois principais mediadores de leitura, a instituiçáo escolar, assim como, em especial, os professores, devem sempre caminhar $\mathrm{m}$ consonância para desempenharem com competência os seus papéis de grande poder e importância basilar para a formação do leitor.

Por isso, primeiramente, a escola pode colaborar com a constituição de um projeto político pedagógico que privilegie a formação não só do aluno leitor como também da comunidade escolar, o que pode englobar funcionários, pais e professores. É preciso também instituir um espaço físico adequado para que ocorram as leituras e sua socialização e, além disso, dispor de biblioteca com acervo de bons livros literários, como também um bibliotecário para auxiliar os alunos.

Aliado às contribuiçôes da escola, o professor também deve se constituir um professor-leitor, conhecer intimamente a origem histórica de obras e autores, assim como ser um constante pesquisador na área das teorias e práticas de leitura. A primeira condição para que um professor, de modo efetivo, concorra para a formação do leitor consiste em mostrar as suas práticas tanto leitora como escrita.

Assim, se o professor não lê nem escreve, dificilmente convencerá seus alunos a tais práticas. Por isso, a formação do leitor passa primeiro pela etapa de envolvimento pelo exemplo e em situaçóes significativas e democráticas de leitura. São essas açóes exercidas pelo professor que revelarão aos alunos os estreitos laços daquele com a leitura e é essa manifestação de intimidade com o universo da leitura que instiga a curiosidade e motiva os alunos à leitura.

No processo de formação de leitores, além da característica fundamental de gostar de ler, o educador também precisa conhecer seu aluno para que 
as leituras tenham bons resultados. Precisa de um mecanismo de motivação o qual consiste na preparação e antecipação da leitura da obra, a fim de minimizar o distanciamento entre o leitor e a leitura literária, como também ampliar o seu horizonte de expectativas. A preparação para a leitura do texto ativa os conhecimentos prévios do leitor, possibilitando relacionar o texto a uma situação que tenham experienciado e isso pode estabelecer um envolvimento capaz de motivar o interesse pela leitura.

Ao longo do percurso traçado buscamos facilitar a ocorrência de leituras significativas, houve, durante as discussóes dos contos, momentos em que a leitura literária ressignificava seus posicionamentos. Tais momentos mostraram-se muito ricos do ponto de vista da prática pedagógica e da pesquisa realizada porque davam visibilidade tanto às características do letramento dos educandos, como da pesquisadora. Possibilitaram, ainda, revisóes em torno de nossa prática pedagógica dado o estágio da nossa formação continuada. Aos educandos, permitiram uma aproximação com a leitura literária, já que tiveram contato com a prática letrada em nossos encontros.

\section{Referências}

AÇÃO EDUCATIVA. Instituto Paulo Monte Negro. Estudo especial sobre alfabetismo e mundo do trabalho. Indicador de Alfabetismo Funcional - INAF, São Paulo, 2016. Disponível em: https://drive.google.com/file/ d/0B5WoZxXFQTCRRWFyakMxOTNyb1k/view. Acesso em: 13 de maio 2018.

ALMEIDA, Geraldo Peçanha de. Práticas de leituras para neoleitores. Curitiba: Pró-Infanti, 2008.

BAUER, Martin W.; GASKELL, George. Pesquisa qualitativa com texto, imagem e som: um manual prático. Rio de Janeiro: Vozes, 2012.

BRUNEL, Carmem. Jovens cada vez mais jovens na educação de jovens e adultos. Porto Alegre: Mediação, 2004.

COENGA, Rosemar. Poesia para pequenos e jovens leitores. In: A leitura em cena: literatura Infanto-Juvenil, autores e livros. Cuiabá: Carlini \& Caniato, 2010.

COENGA, Rosemar; GRAZIOLI, Fabiano Tadeu. Escola, professores e formação de leitores literários. In: Literatura Infanto-juvenil e leitura: novas dimensóes e configuraçóes. Erechim: Habilis, 2014.

COLOMER, Teresa. Andar entre livros: a leitura literária na escola. São Paulo: Global, 2007. 
COSSON, Rildo. Círculos de leitura e letramento literário. São Paulo: Contexto, 2014.

COSSON, Rildo. Letramento literário: teoria e prática. São Paulo: Contexto, 2016.

DI PIERRO, Maria Clara. Luta social e reconhecimento jurídico do Direito Humano dos jovens e adultos à educação. Revista Educação v. 33, n. 3, set./dez. 2008. Disponível em https://periodicos.ufsm.br/reveducacao/ article/view/1617/911 acesso em 01 de maio de 2018.

EITERER, Carmem Lucia; ABREU, Juliana Valéria de. O letramento literário e a educação de jovens e adultos. Revista Diálogo Educacional (PUCPR), v. 9, p. 149-160, 2009.

KLEIMAN, Ângela. Oficina de leitura: teoria e prática. Campinas: Pontes, 2012.

LAROSSA, Jorge. Literatura, experiência e formação. In. COSTA, Marisa Vorraber (org.). Caminhos investigativos: novos olhares na pesquisa em educação. Rio de Janeiro: DP e A, 2002.

LEFFA, Vilson José. Perspectivas no estudo da leitura; Texto, leitor e interação social. In: LEFFA, Vilson José; PEREIRA, Aracy, Ernst. (orgs.). O ensino da leitura e produçáo textual: alternativas de renovação. Pelotas: Educat, 1999. p. 13-37.

LISPECTOR, Clarice. A via crucis do corpo. Rio de Janeiro, Rocco, 1998.

PAULINO, Graça; COSSON, Rildo. Letramento literário: para viver a literatura dentro e fora da escola. In: ZILBERMAN, Regina; RÖSING, Tania (orgs.). Escola e leitura: velha crise; novas alternativas. São Paulo: Global, 2009.

PAULINO, Graça; PAIVA, Aparecida; EVANGELISTA, Aracy \& VERSIANI, Zélia (org.). No fim do século: a diversidade - o jogo do livro infantil e juvenil. Belo Horizonte: Autêntica, 2000.

SILVA, Ezequiel Theodoro da. Concepçóes de leitura e suas consequências no ensino. Perspectiva, Florianópolis, v.17, n. 31, p. 11-19, jan. /jun. 1999.

SOARES, Magda. A escolarização da literatura infantil e juvenil. In: EVANGELISTA, Aracy et al. (orgs.). Escolarizaçáo da leitura literária. Belo Horizonte: Autêntica, 1999, p.17-4. 
SOARES, Magda. Letramento: um tema em três gêneros. Belo Horizonte: Autêntica, 2003.

THIOllENT, Michel. Metodologia da Pesquisa-ação. São Paulo: Cortez, 1986.

TIEPOLO, Elisiani Vitória. Os neoleitores e a leitura de textos literários. In: Salto para o futuro: literatura e neoleitor. Rio de Janeiro, n. 8, p.5-13, 2010. Disponível em: https:/cdnbi.tvescola.org.br/resources/ VMSResources/contents/document/publicationsSeries/10273208LiteraturaNeoleitor.pdf. Acesso em 14 de maio 2018

TIEPOLO, Elisiani Vitória. Uma política de leitura para todos: leitores e neoleitores. Em Aberto, Brasília, v. 22, n. 82, p. 121-133, nov. 2009. Disponível em: http://emaberto.inep.gov.br/index.php/emaberto/article/ view/2246/2213. Acesso em: 14 de maio 2018.

\section{Entrevistas}

A1. Entrevista concedida a Antônia Lúcia de Queiroz Tenório. Cuiabá, 8 de ago. 2017.

A2. Entrevista concedida a Antônia Lúcia de Queiroz Tenório. Cuiabá, 8 de ago. 2017.

A3. Entrevista concedida a Antônia Lúcia de Queiroz Tenório. Cuiabá, 9 de ago. 2017.

A4. Entrevista concedida a Antônia Lúcia de Queiroz Tenório. Cuiabá, 9 de ago. 2017.

A5. Entrevista concedida a Antônia Lúcia de Queiroz Tenório. Cuiabá, 10 de ago. 2017.

A6. Entrevista concedida a Antônia Lúcia de Queiroz Tenório. Cuiabá, 10 de ago. 2017. 


\title{
Capítulo 9 \\ FORMAÇÃO DE ESTUDANTES DA EJA: EDUCAÇÃO E CONSCIÊNCIA AMBIENTAL NA ESCOLA DUQUE DE CAXIAS EM HUMAITÁ/AM
}

\author{
Valmir Flores Pinto \\ Romilson Brito de Azevedo
}

\section{Introdução}

Nas últimas décadas os problemas ambientais ganham cada vez mais notoriedade e relevância social, decorrentes da grande diversidade ou pelo agravamento e frequência com que ocorrem diversas agressóes ao meio ambiente. Nesse sentido, faz com que seja cada vez mais comum e se torne prioridade, utilizando diferentes áreas do conhecimento que oportunize soluçóes, enfatizando principalmente a Educaçáo Ambiental (FERREIRA, 1998).

$\mathrm{Na}$ Educação de Jovens e Adultos (EJA) há um grande desafio a ser encarado, pois como um processo educativo que visa transmitir novos conhecimentos, em busca de desenvolver uma atitude educacional mais crítica e criativa, devido à realidade socioeconômica, cultural e ambiental no mundo em que vivemos, cabe também, buscar o diálogo entre os saberes e as experiências que os jovens e adultos acumulam e trazem para a sala de aula, como se fosse uma bagagem intelectual em suas vidas. (SILVASANCHEZ, 2000).

A EJA no Brasil encontra fundamentos nos Parâmetros Curriculares Nacionais (PCN). Essa modalidade de educação, bem como as demais, aborda a Educação Ambiental como um tema transversal (BARBOSA, 2008). A Educação Ambiental decorre de uma percepção renovada de mundo, na qual atualmente a crise ambiental fez com que a sociedade refletisse sobre seu modelo de desenvolvimento, visando motivar respostas mitigadoras e propulsoras.

\section{Educação ambiental e sensibilidade}

O ensino, considerando a temática meio ambiente, deve ser desenvolvido com vistas a proporcionar aos alunos vasta diversidade de experiências, ensinando-lhes formas de participaçáo para que possam ampliar os 
conhecimentos sobre as questóes ambientais relativas ao meio ambiente e assim, de forma independente, os valores voltados para sua proteção e melhoria, passando da curiosidade à consciência crítica (SEGURA, 2001).

Em relação ao meio ambiente, a Educação Ambiental deve instruir a populaçáo, especialmente a população escolar, partindo do pressuposto que não basta apenas saber o certo ou errado, mais sim conhecer a importância ambiental. Cabe assim uma aprendizagem na qual se compreenda que a preservação não é apenas cuidar da natureza e sim um modo como se relaciona com meio ambiente, o que contribuirá consequentemente para a melhoria da qualidade de vida. (DIAS, 2000).

Nessa direção, entendemos que é importante que o ser humano repense sua postura no mundo de hoje em relação ao ambiente, de modo a desenvolver um novo sentimento de preservação e visão do planeta terra, fazendo com que os instrumentos se adequem ao cidadão, proporcionando oportunidades para a formação de consciência e se responsabilizando pelo destino de sua própria vida (CAVALCANTE, 2002).

Uma vez que se consiga a sensibilizaçáo de a população para uma educaçáo ambiental consciente, caracteriza-se uma ação objetiva sobre as questóes ambientais e se proporciona ferramentas para uma atuação consciente em relação ao meio ambiente e seus usos, possibilitando discussóes e reflexóes sobre a própria condição do indivíduo. (CUNHA, 2005).

Como dito por Cunha e Guerra (2005), a escola por ser um espaço social no qual o aluno nela vive, faz, diz e se valoriza, no aspecto mais amplo de socialização, também deseja que os melhores exemplos aconteçam na sociedade. Nessa perspectiva, comportamentos do ambiente devem ser estudados na prática, no cotidiano da vida escolar, na contribuição para a formação de cidadãos responsáveis, capazes de compreender a educaçáo ambiental, as questóes ambientais e as transformaçôes de conhecimentos, valores e atitudes que poderáo ser seguidos diante da nova realidade a ser construída frente à consciência ambiental que julgamos ser necessária.

Diante do exposto, o objetivo é possibilitar reflexóes a respeito da conformação de valores fundamentais na construção da consciência ambiental, na percepção dos estudantes da EJA de uma Escola Estadual. Buscou-se, dessa forma, materializar o objeto de estudo por meio da aplicação dos questionários aos alunos, de modo a analisar os resultados das percepçóes em percentuais e obtenção dos resultados. 


\section{Percurso da pesquisa}

Inicialmente foi realizada uma pesquisa bibliográfica, em seguida a pesquisa de campo na Escola Estadual Duque de Caxias, na cidade de Humaitá$\mathrm{AM}^{1}$, onde se aplicou questionários semi-abertos, em duas classes de alunos finalistas do EJA, para um total de 45 (quarenta e cinco). Para a aplicação do questionário foram seguidas as seguintes etapas:

I. Apresentação do pesquisador e exposição dos objetivos da pesquisa;

II. Reiteração sobre o anonimato dos participantes e a confiabilidade de suas respostas;

III. Informação sobre os questionários que continham questóes a deliberação de cada um em responder e, por fim;

IV. Instruçóes especificas sobre a forma de responder aos questionários.

O questionário continha questóes que visavam identificar as disciplinas que mais abordavam temáticas sobre o meio ambiente na sala de aula, perguntas ambientais em geral, pergunta sobre o local em que os alunos têm mais acesso às informaçóes sobre o meio ambiente. Os dados obtidos foram tabulados e analisados por procedimentos estatísticos e estão expostos ao longo do texto em forma de gráficos.

Também foi realizada uma análise do material didático utilizado na escola e disponibilizado para professores da EJA, visando identificar se continham conteúdos informativos relacionados à temática da Educação Ambiental e quais metodologias eram utilizadas pelos professores para transmitir as informaçóes aos alunos sobre a temática.

\section{Educação Ambiental: construção de valores sociais e competência para conservação}

A Educação Ambiental, na maioria das vezes, conforme pode ser observada a partir da análise realizada, é entendida como um processo que por meio do qual o indivíduo e a coletividade constroem valores sociais e a competência para conservação do meio ambiente, essenciais para a qualidade de vida e a sustentabilidade.

1 Humaitá é um município do interior do Amazonas, fica a $700 \mathrm{~km}$ da Capital Manaus. Atualmente conta com uma populaçáo estimada (2018) de 54.001 pessoas. Fonte: https:// cidades.ibge.gov.br/brasil/am/humaita/panorama. 
A compreensão de Educação Ambiental como uma dinâmica que incorpore elementos diferenciados que agregue valores éticos e comprometedores com o viver e conviver busca uma prática que a supera elementos de uma sociedade dominante, por meio do emprego de práticas pedagógicas cotidianas visando influenciar uma mudança de comportamento da população, formando cidadáos conscientes do processo de mudanças do atual estado ambiental, cuja participaçáo ativa deve buscar a superação de problemas sociais, econômicos e ambientais nas comunidades nas quais estáo inseridos, e hoje com a ajuda de novas tecnologias e também amparada com a Legislação Ambiental ou Direito Ambiental, conforme fundamenta Antunes (2008) são capazes de interferir na qualidade do meio ambiente.

Analisando os dados obtidos, é possível verificar a necessidade de inclusão da Educação Ambiental no currículo da EJA e, de modo mais específico, em determinadas disciplinas. Durante a visita à escola pesquisada verificou-se que alguns professores afirmam que abordam a temática, porém, não adentram ao assunto de forma mais intensa com as discussóes. Isto ocorre porque, segundo esses professores, isso os levariam a desviar-se de assuntos específicos de suas disciplinas, uma vez, como a própria legislação ampara, o tema da educação ambiental ainda é tratado de forma transversal.

Cabe salientar a forma simplista de compreensão de alguns professores entrevistados em relação ao tema Educação Ambiental. Alguns utilizam apenas vídeos-aulas para expor assuntos sobre o meio ambiente e suas possíveis problemáticas. Um desses problemas é explorado a partir da exposiçáo de questóes como o crescimento populacional e a demanda dos recursos para suprir as necessidades humanas e as crises decorrentes de exploraçáo desordenada do meio ambiente. Contudo, é importante ressaltar que outros professores, confundem Educação Ambiental com Ecologia, o que demonstra a necessidade de aprofundamento conceitual com relação aos conteúdos desenvolvidos durante a realizaçáo das disciplinas.

Nas etapas para a análise de materiais didáticos utilizados em sala de aula, como os livros de Biologia, Linguagens e Culturas, Ciências da Natureza e Matemática, Ciências Humanas, procurou-se levar em consideraçáo os conteúdos específicos ou aproximativos sobre a temática da Educação Ambiental e temas transversais relacionados ao assunto, uma vez que sabemos que os livros didáticos são um importante recurso, com significativa influência no processo de ensino-aprendizagem, muitas vezes constituindo a única fonte bibliográfica utilizada por professores e alunos.

Com relação às respostas contidas nos questionários aplicados, realizou-se uma análise a partir de cada questionamento e consoante a resposta obtida. 
Na questão na qual foi perguntado "O que é Educação Ambiental?", podemos observar no Gráfico 1 que 42,20\% responderam que compreendem que ela está relacionada à preservaçáo da vida no planeta; $35,50 \%$ responderam que Educação Ambiental é promover projetos de preservaçáo ambiental e $22,22 \%$ reconhecem os problemas ambientais.

\section{Gráfico 1 - Educação Ambiental.}
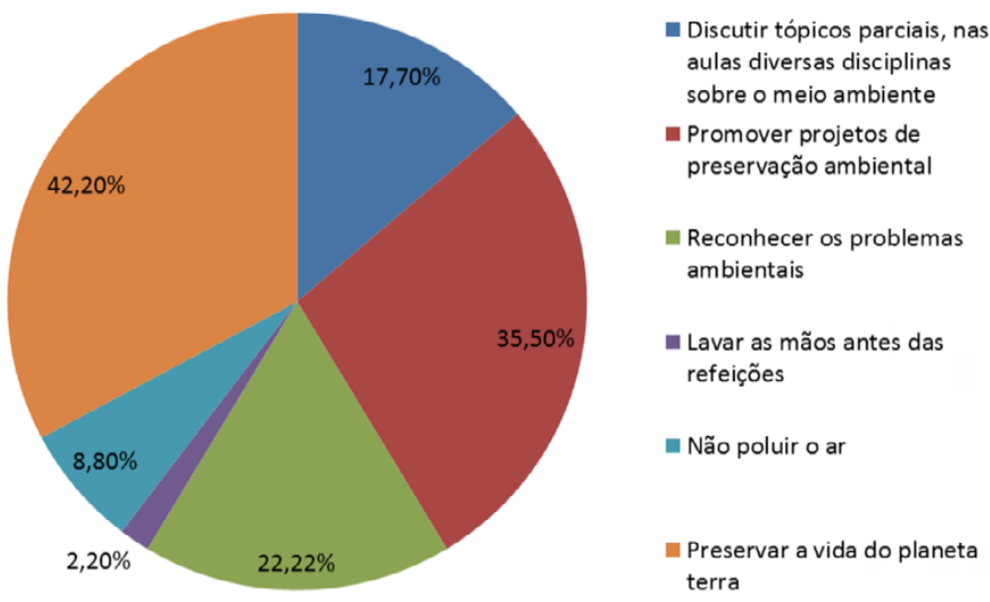

Fonte: Os autores.

Em relação a esse gráfico, pode-se perceber que a compreensão de ambiente ainda é vista como algo "externo" ou desligado. Através dos estudos de Sauvé (1996) e Sauvé et al. (2000), identificam representaçóes sobre o ambiente: ambiente como natureza, como recurso, como problema, como meio de vida, como sistema, como biosfera e ambiente como projeto comunitário. O ambiente como natureza é aquele percebido de forma original e "puro", do qual os seres humanos estão dissociados e no qual devem aprender a relacionar-se. As palavras chave e imagens que vêm à mente são "meio natural", "árvores", "plantas", "animais", "cachoeiras", etc.

Para Sauvé (1996), nesta percepção o problema identificado para a e Educação Ambiental é a dissociação do ser humano da natureza. A Educação Ambiental deve promover estratégias de imersão na natureza, renovando, deste modo, os laços com a mesma, desenvolvendo um sentimento de pertencimento, de admiração e de respeito pelo meio natural.

$\mathrm{Na}$ questáo que interrogava "em que lugar você costuma ter acesso à Educação Ambiental?”, como podemos observar no Gráfico 2, 66,66\% dos 
alunos têm acesso à Educação Ambiental na escola e 26,66\% costumam ter acesso ao tema por meio de programas transmitidos pela televisão.

Esta resposta é um sinal de mais de $50 \%$ da presença da Educação Ambiental no ambiente escolar, o que vem reforçar um modelo de educação que apesar de uma presença significativa a formação ainda não tem reflexos na inclusão e socialização com as questóes ambientais. O discurso ambiental, como objeto de reflexão sobre o qual se está estudando, acaba por se repetir ou decorar conteúdos. Dessa forma, a aprendizagem real fica prejudicada, configurando uma mera transmissão dos conteúdos.

\section{Gráfico 2 - 0 acesso sobre a Educação Ambiental.}

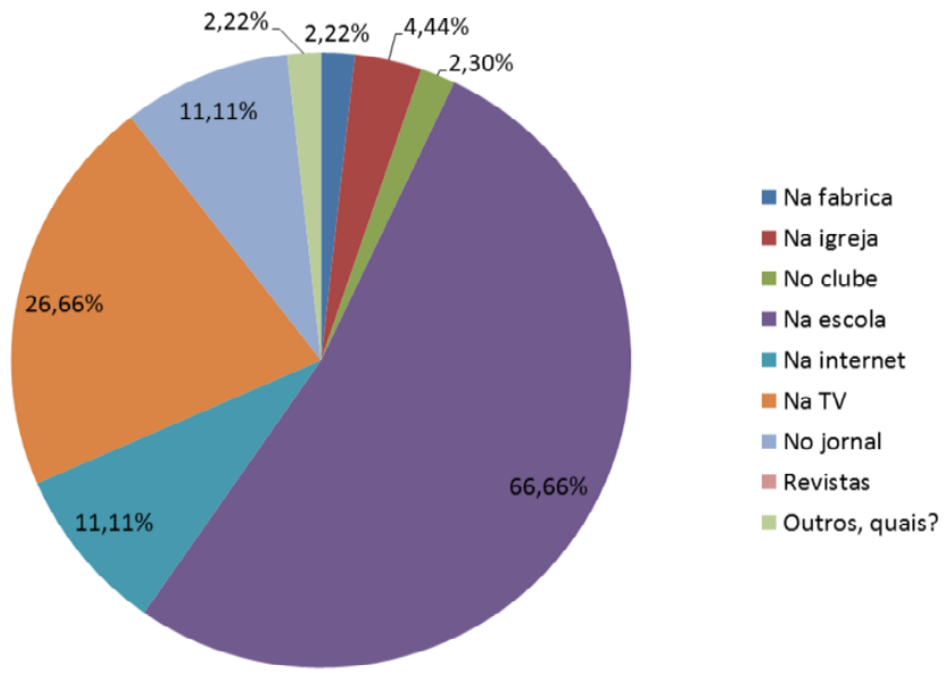

\section{Fonte: Os autores.}

Visando saber que atividades os alunos mais querem desenvolver na sua escola em busca de uma melhor qualidade ambiental da comunidade escolar, foi dado algumas opçôes de açóes a desenvolver, e como se pode conferir no Gráfico 3. Obteve-se as seguintes respostas: 33,33\% dos alunos querem desenvolver uma horta na escola e 26,66\% querem produzir um jardim.

As açóes de nível prático estão presentes nas opçóes dos alunos, de onde se deduz que também é possível incorporar elementos de Educação Ambiental nessas atividades, principalmente se levarmos em consideraçóes práticas transversais que compóe universo educativo. 


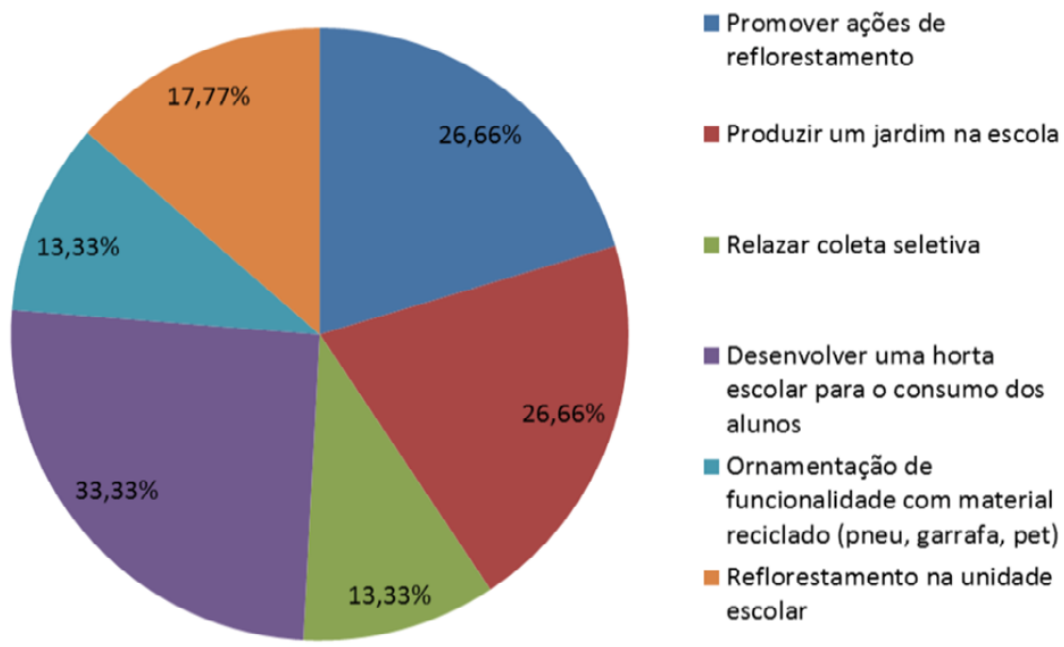

Fonte: Os autores.

Em outra questão se questionou: "Que área do ensino mais aborda a temática da Educação Ambiental em sala de aula? ”

Como podemos observa no Gráfico 4, 53,30\% dos alunos afirmaram que a disciplina de Geografia é a que mais desenvolve o conteúdo sobre Educação Ambiental e 2,20\% afirmaram ser a disciplina de Biologia a que mais aborda o assunto.

Verifica-se que apesar da escola ter livros didáticos que trazem conteúdos sobre Educação Ambiental, pouco se tem de conhecimento sobre o assunto em si. Pode-se afirmar que como conteúdo transversal é um assunto pouco estudado, e com isso um dos objetivos mais importantes da educaçáo, a cidadania, fica prejudicado conforme o Art. 5º, inciso III da Lei 9.795/1999 que trata da Política Nacional de Educação Ambiental que visa a promoçáo da cidadania, autodeterminação e solidariedade como fundamentos para o futuro da humanidade.

Verificou-se que os conteúdos dos livros didáticos analisados sob a perspectiva ambiental, não estão cumprindo com a função da concepção da Educação Ambiental e de uma educação para uma escola crítica, capaz de formar um aluno crítico sujeito de sua aprendizagem, conhecedor de sua realidade sócio- ambiental e capaz de nela intervir. 
Gráfico 4 - Temática mais abordada na sala de aula.

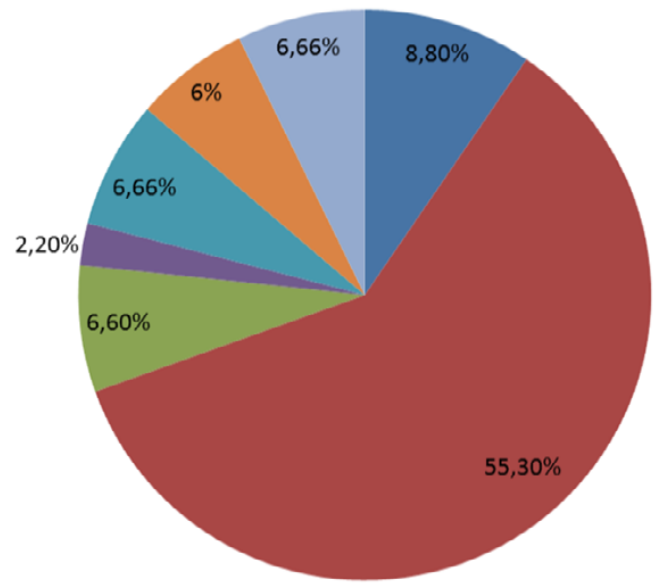

Fonte: Os autores.

\author{
natemática \\ neografica \\ nuímica \\ - Língua Portuguesa \\ - História \\ - Sociologia \\ Filosofia \\ nísica \\ Ensino Religioso \\ Biologia \\ Nenhuma das areas acima
}

Quando se perguntou sobre em qual conteúdo a Educação Ambiental surge, se nas disciplinas estudas ou em projetos, como se observa no Gráfico 5 , a seguir, $57,70 \%$ dos alunos responderam que tem acesso a estes conteúdos por projetos, no caso específico, no "Café filosófico" realizado na UFAM Universidade Federal do Amazonas, campus Humaitá-AM. ${ }^{2}$

\section{Gráfico 5 - Conteúdos sobre a educação ambiental, surgimento de disciplinas ou projetos.}

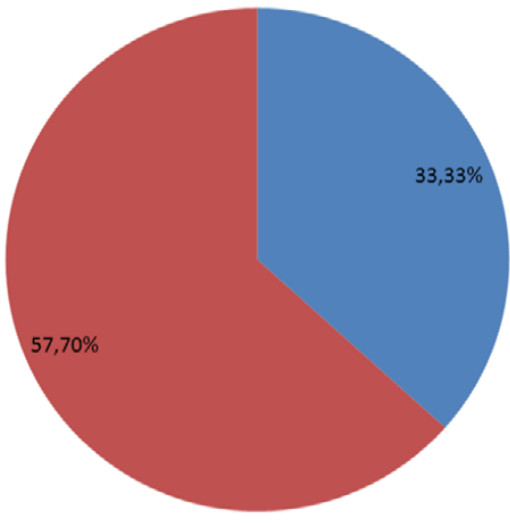

Fonte: Os autores.

2 Projeto de Extensão No. PACE 337/2015/2 - "Café Filosófico na EJA em Humaitá" - A reflexáo acadêmica sobre temas filosóficos atuais e considerados "corriqueiros": felicidade, sofrimento, autoconfiança, raiva, amor e autoestima. Neste sentido foram abordados autores como Sócrates, Sêneca, Epicuro, Montaigne, Schopenhauer e Nietzsche, bem como abordagem histórica e filosófica sobre alguns filósofos ocidentais. O projeto foi coordenado pelos Professores Dr. Valmir Flores Pinto e Dra. Rosimeri da Silva Pereira. 
Quando foi perguntado sobre a potencializaçáo de projetos, que estudos específicos que os alunos gostariam que a sua escola desenvolvesse sobre a questáo ambiental, alguns responderam que:

Entrevistado 1: Ensinar os alunos a reciclar os papéis, pneus, papéis, etc. para que cada um tivesse uma criatividade em reaproveitar os materiais que iria prejudicar o meio ambiente.

Entrevistado 2: Projetos: uma forma de reflorestamento em nossa cidade, e reaproveitamento com o lixo.

Em outra questáo foi perguntado a opiniáo dos alunos sobre como podemos contribuir na formação de jovens mais preocupados e conscientes frente à problemática da questão ambiental. Alguns responderam:

Entrevistado 3: Promover projeto de preservação ambiental com os alunos, ouvindo suas opiniōes e o que eles acham disso.

Entrevistado 4: Podemos contribuir na educação, incentivando a jogar o lixo no local indicado e não jogar lixo nos rios e nas ruas, não desmatar.

Analisando as respostas dos entrevistados é possível estabelecer um canal de diálogo e criar mecanismos de açáo entre comunidade educativa e comunidade externa. Segundo Stapp et al. (1996), o 'empoderamento' se dá quando a educaçáo permite que educador e educando participem de processos que os conscientizem de suas opçóes e os encorajem a agir, exercitando seu papel de cidadáos. "Precisamos desenvolver uma abordagem de aprendizagem que estresse a compreensão de risco e habilidades como pensamento crítico, resolução de problemas e trabalhos grupais" (STAPP et al., 1996, p. 13).

Em outra questão foi perguntado "Durante as aulas, de modo geral, a Educação Ambiental se apresenta como?". O Gráfico 6 demonstra que 35,50\% afirmam que a Educação Ambiental se apresenta como complemento programático das disciplinas ou algum interesse de professor, representando, neste caso, 33,33\%.

A pouca preocupaçáo com a consciência ambiental, constatada no estudo realizado, é uma amostra significativa do que existe no universo escolar que muitos jovens recebem em nossas instituiçóes educativas, ainda mais quando a sociedade reforça um modelo que explora a natureza de uma forma que não dá um retorno sustentável, conforme constatam Hirata e Moura (2013). Os autores reafirmaram a importância da formaçáo de cidadáos participativos na construçáo de sociedade sustentáveis (HIRATA; MOURA, 2013, p. 2). 
Por isto, não basta apenas informar, mas conhecer o que de real existe na formação desse público possibilitará um retorno mais efetivo.

\section{Gráfico 6 - Gráfico referente de um modo geral a Educação Ambiental se apresenta}

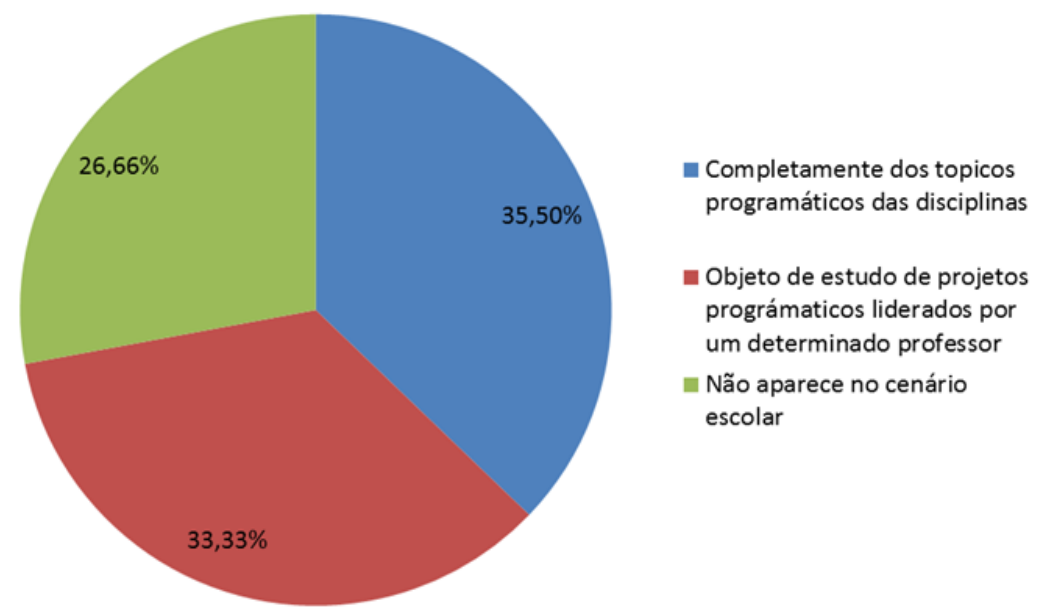

Fonte: Os autores.

\section{Considerações finais}

A partir de o material consultado e das falas se verifica a importância da inclusão da Educação Ambiental não só no currículo, mas na cultura educacional. Entendemos que isto não é uma responsabilidade apenas das autoridades que conduzem a estrutura do ensino que vai desde dos manuais escolares até o Ministério da Educação. A cultura educacional tem um aporte fundamental e político primeiro, sim, na política de Estado, mas a sociedade civil, as organizaçôes não governamentais, os movimentos sociais as Escolas podem e podem contribuir e cobrar para que tenhamos uma Educação Ambiental mais comprometida com a qualidade de vida e o desenvolvimento humano e social.

De acordo com os resultados obtidos foi observado um grande interesse por parte dos educandos da EJA, apesar de seus conhecimentos prévios e inseguros, devido à falta de uma formação mais adequada por parte dos educadores.

No entanto, muitos textos aparecem desvinculados da realidade do aluno. Pode-se afirmar ainda, que há livros didáticos em relação à temática ambiental, que não utilizam os textos como um meio para se atingirem os 
fatos, mas para se saber o conteúdo enquanto um fim em si mesmo, isto é, o estudante passa a decorar o conteúdo. Isso não é aprendizagem, mas transmissão de conteúdos.

Segundo $57,70 \%$ dos alunos afirmam que tem mais contato com conteúdos sobre Educação Ambiental por meio de projetos, logo se pode observar uma necessidade de a escola utilizar este espaço e ferramenta de trabalho para desenvolver atividades que relacionam os alunos com contexto do meio ambiente, com suas problemáticas e relaçáo homem/natureza.

A mudança de postura em relação ao meio ambiente é um desafio para todas as etapas formativas. Se durante a fase infantil e juvenil ela não foi bem trabalhada, com certeza terá mais dificuldade na fase adulta. Dessa forma, é necessário reforçar o ensino e os questionamentos relacionados ao meio ambiente na comunidade escolar, inserindo assim novos conceitos para modificar a percepção errônea de muitos jovens e adultos da EJA e com isso promover uma sociedade mais consciente, a exemplo, com problemas recorrentes como a necessidade de diminuição do lixo a ser dispensados nos aterros sanitários na cidade, a preservação e conservação dos recursos naturais e a formação de uma imagem ecologicamente correta do meio ambiente, a discussão e promoção de políticas públicas relacionadas à temática.

\section{Referências}

ANTUNES, Paulo de Bessa. Direito ambiental. 11. ed. Rio de Janeiro: Lúmen júris, 2008.

BARBOSA, Luciano Chagas. Políticas públicas de educaçáo ambiental numa sociedade de risco. Tendências e desafios no Brasil. IV Encontro Nacional da Anppas. Brasília - DF - Brasil. 2008. p. 2/10.

CAVALCANTE, Clovis. (org.). Meio ambiente, desenvolvimento sustentável e política. 4. ed. São Paulo: Cortez, Recife, Fundação Joaquim Nabuco, 2002.

CUNHA, Sandra Baptista, GUERRA, Antônio José de Teixeira (org.). Impactos ambientais urbanos no Brasil. 3. ed. Rio de Janeiro: Bertrand Brasil, 2005.

DIAS, Genebaldo Freire. Educaçáo ambiental. Princípios e práticas. 6. ed. São Paulo: Editora Gaia, 2000.

FERREIRA, Leila da Costa. A questáo ambiental: sustentabilidade e políticas públicas no Brasil. São Paulo: Boitempo, 1998. 
HIRATA, Carlos Alberto; MOURA, Jeani Delgado Paschoal. A Educação Ambiental em Debate. Pro-Docência. Revista Eletrônica das Licenciaturas/ UEL. Edição No. 5, Vol. 1, jul-dez. 2013. ISSN 2318-0013 - Disponível em: http://www.uel.br/revistas/prodocenciafope. Acesso em: 13 maio 2018.

IBGE. Disponível em: https://cidades.ibge.gov.br/brasil/am/humaita/ panorama. Acesso em 13 de maio 2018.

SAUVÉ, Lucie. Envirnmental Education and Sustainable Development: A Further Appraisal. Canadial Journal of Environmental Education, v. 1, p. 7-54, 1996.

SAUVÉ, Lucie. A formação continuada de professores em Educação Ambiental: a proposta do EDAMAZ. In: Sato, Michele e Santos, José Eduardo dos. (orgs.). A contribuiçáo da Educaçáo Ambiental à esperança de Pandora. São Carlos, RIMA. 2000.

EDAMAZ. In: Sato, Michele e Santos, José Eduardo dos. (orgs.). A contribuiçáo da educaçáo ambiental à esperança de Pandora. São Carlos, RIMA. 2000.

SEGURA, Denise de S. Baena. Educação ambiental na escola pública: da curiosidade ingênua à consciência crítica. São Paulo: Annablume: Fapesp, 2001.

SILVA-SÁNCHEZ, Solange S. Cidadania ambiental: novos direitos no Brasil. São Paulo: Humanistas; FFLCH; USP, 2000.

STAPP, Wals; WALS, Arjen E.J.; STANKORB, S.L. Environmental education for empowerment: action research and community problem solving. Iowa: Kenda/Hunt Publishing Company. 1996. 


\section{MODELAGEM MATEMÁTICA NO ENSINO DE FUNÇÃO AFIM EM UMA TURMA DE EDUCAÇÃO DE JOVENS E ADULTOS NO MUNICÍPIO DE JUÍNA-MT}

Jefferson Bento de Moura

\section{Introdução}

Segundo o dicionário etimológico, a palavra matemática significa arte ou técnica de explicar, de conhecer, de entender os números e as formas geométricas. Alguns profissionais possuem o dom de desenvolver essa arte e conseguem transmiti-la muito bem aos discentes, de forma que conseguem ótima compreensão por parte maioria. Ao mesmo tempo, alguns alunos, por mais eficiente que seja a didática utilizada pelo professor, náo conseguem alcançar completo aproveitamento do conteúdo ministrado, possuindo dificuldades em desenvolver as atividades propostas.

Com base nessas dificuldades apresentadas no processo de ensino-aprendizagem referente ao conteúdo de função afim pelos alunos em geral, que surgiu a ideia de desenvolver o presente trabalho, com um diferencial que é o de analisar se com um novo recurso (a modelagem matemática) como forma de expor o conteúdo, saindo um pouco da aula tradicional, obteve-se melhores resultados na Educação de Jovens e Adultos - EJA.

Segundo Biembengut e Hein (2014, p.12) a modelagem matemática é o processo de se obter um modelo, utilizando situaçôes do dia a dia, ou seja, ela é um meio de fazer com que a matemática se relacione com a realidade, necessitando para isso que o criador desse modelo tenha um conhecimento matemático significativo, tenha senso lúdico para brincar com as variáveis envolvidas no processo, tenha uma dosagem de intuição e criatividade para interpretar o contexto e saber relacionar que conteúdo matemático se adapta melhor.

A educação de jovens e adultos é composta em sua grande maioria por trabalhadores, o que não permite muitas vezes a realização de atividades extraclasses, dificultando assim a fixação do conteúdo, sendo que o único acesso a ele pelo aluno é dentro da sala de aula. Por meio da modelagem matemática busca-se uma interação entre o conteúdo 
ministrado e situaçóes do cotidiano, permitindo aos alunos presenciarem a matemática e relacioná-la em situaçóes do dia-a-dia facilitando o processo de aprendizagem.

A pesquisa foi desenvolvida no Centro de Educaçáo de Jovens e Adultos Alternativo (CEJA Alternativo) do município de Juína/MT, com uma turma de nível médio, para a obtençáo dos dados para a análise dos resultados.

Com os resultados obtidos pela pesquisa será possível verificar se com uma didática diferenciada conseguiu-se atingir de forma mais compreensível os conceitos e definições aos alunos da educação de jovens e adultos, permitindo assim que eles tivessem um conhecimento/ aprendizado duradouro, náo somente temporário. A partir desses resultados poderemos comprovar se houve uma melhoria no nível de aprendizagem dos alunos e proporcionar aos docentes uma alternativa metodológica eficiente através da modelagem matemática.

\section{Educação Matemática e Educação de Jovens e Adultos}

A educação de jovens e adultos é vista como um sinal de desenvolvimento econômico e social do país, portanto ela é proveniente da falta de desenvolvimento, da situação de miséria visto que, a maior parcela de jovens e adultos abandonaram seus estudos na idade certa por causa da inclusão mais cedo no mercado do trabalho, buscando ajudar seus familiares a obter o sustento diário e, falta de condiçôes para chegarem às instituiçóes de ensino.

Muitas vezes remetemos o termo EJA a idade dos alunos que compóe essa modalidade de ensino, portanto o grande traço definidor da EJA é a caracterização sociocultural de seu público, no seio da qual se deve entender esse corte etário que se apresenta na expressão que a nomeia. (FONSECA, 2007, p.15).

Um aluno jovem ou adulto pode ser incluído no sistema regular de ensino voltado para crianças de sete a quatorze anos, desde que se desenvolva um trabalho pedagógico direcionado não só para a faixa etária a qual foi originalmente idealizado, mas sim um ensino que seja inclusivo, permitindo a interação desse aluno com o restante da classe se não, o mesmo pode sentir-se desconfortável diante da metodologia abordada.

Diante dessas diferenças e incompatibilidades, que o sistema de ensino sofreu algumas reformas desde a Constituição de 1988, 
originando assim os centros de ensinos de jovens e adultos garantindo uma educação de qualidade para todos e, permitindo o retorno desses alunos aos bancos escolares.

A Educação Matemática de Jovens e Adultos, não se refere ao ensino da matemática aos estudantes universitários ou da pós-graduação. Segundo Fonseca (2007, p.14), refere-se a uma ação educativa dirigida a um sujeito de escolarizaçáo básica incompleta ou jamais iniciada e que ocorre aos bancos escolares na idade adulta ou na juventude.

Sendo assim, ao elaborar uma aula de matemática para os alunos da educação de jovens e adultos, deve-se levar em consideração que os mesmos já possuem um conhecimento prévio, que muitas vezes podem ser utilizados como modelos de aplicação de um determinado conteúdo, tornando assim a disciplina mais atraente uma vez, que esse aluno percebe que o que está sendo ensinado a ele está diretamente ligado a realidade em que vive.

Aos profissionais envolvidos na Educação de Jovens e Adultos é orientado que levem em consideração os conhecimentos prévios dos alunos, o contexto ao qual está inserido, assim como a instituição a que ele pertence, as necessidades que os fizeram retornarem aos bancos escolares e, principalmente, que tenham uma sensibilidade acentuada para evitar situaçóes que venha a provocar a evasão desse individuo novamente do ambiente escolar. (OLIVEIRA; BITENCOURT, 2015).

A falta de experiência com a docência voltada para essa área remete o professor a obter alguns cuidados, conforme Fonseca salienta:

$\mathrm{Na}$ educaçáo matemática que se realiza no âmbito dos projetos de alfabetização de adultos, o risco de uma inadequação identificada com a infantilização das estratégias de ensino e, entre elas, das atividades propostas aos alunos advém de uma transposição pouco cuidadosa de procedimentos concebidos no trabalho com crianças com idades inferiores há sete anos para o ensino de Matemática no contexto da Educação de Jovens e Adultos. (FONSECA, 2007, p. 35).

As instituiçóes educacionais e os educadores, principalmente os educadores de matemática, devem se comprometer com uma política de inclusão e de garantia de espaço de jovens e adultos na Escola, tomandoos como sujeitos socioculturais, que apresentam perspectivas e expectativas, demandas e contribuições, desafios e desejos próprios em relação à Educação Escolar (FONSECA, 2007, p.32). 


\section{Modelagem matemática como forma de demonstração do conhecimento}

A modelagem ou arte de modelar é uma técnica que surge da própria razão e faz parte da nossa vida como forma de demonstração do conhecimento. Ela é um ambiente de aprendizagem no qual os alunos são convidados a indagar e/ou investigar, por meio da matemática, situaçóes oriundas de outras áreas da realidade (BARBOSA, 2001, p. 6). Para isso, há a necessidade de elaborar um modelo, ou seja, um método para demonstrá-lo. Dentro desta perspectiva, um conjunto de símbolos e relaçóes matemáticas que busca traduzir, de alguma maneira, um fenômeno em questão ou problema de situação real, é denominado de modelo matemático (BIEMBENGUT; HEIN, 2014, p.12).

Ainda sobre a definição de modelo matemático encontramos em Bassanezi (1999, p.12) que, é um conjunto consistente de equaçóes ou estruturas matemáticas, elaborado para corresponder a algum fenômeno e que este pode ser físico, biológico, social, psicológico, conceitual ou até mesmo um outro modelo matemático. As atividades de modelagem são consideradas como oportunidades para explorar os papéis que a matemática desenvolve na sociedade contemporânea (BARBOSA, 2001 p. 4). O modelo é sempre uma aproximaçáo apropriada da realidade que se encontra em análise e está sujeito a mudanças, por isso ele nunca determina uma verdade em definitivo. Para Burak (1992), um modelo deve explicar, de forma satisfatória, um fenômeno estudado.

De acordo com Biembengut e Hein (2014, p.12), modelagem matemática é o método que envolve a obtenção de um modelo. Se o modelador possuir um conhecimento de matemática mais aprofundado ele pode elaborar modelos mais sofisticados se não, seu modelo pode ficar restrito a uma matemática elementar. Mas, o valor do modelo não está limitado à sofisticação matemática.

A interação entre a realidade e a matemática ocorre por meio da modelagem. Essa interação possibilita representar uma situação real com o modelo matemático, envolvendo uma série de procedimentos. Segundo Biembengut e Hein (2014, p.13), esses procedimentos são agrupados em três etapas, cada uma subdividida em duas, são elas: Interação; Matematização e Modelo Matemático.

$\mathrm{Na}$ in teração, o modelador vai realizar um levantamento sobre o assunto utilizando-se de uma maneira indireta ou direta (in loco), permitindo assim que a situação-problema fique cada vez mais clara conforme ele vai interagindo com os dados. A matematização é a etapa na qual ocorre a transformação da situação-problema em uma linguagem matemática, 
necessitando de intuiçáo, criatividade e experiência acumulada por parte do modelador uma vez formulada essa situação-problema entrase no processo de resolução, utilizando o modelo matemático de que se dispóe. Por último, é realizado a interpretação do modelo verificando em que nível ele se aproxima da situação-problema e também o grau de confiabilidade na sua utilização através de uma avaliação, é nessa etapa que caso o modelo não se adeque as necessidades de sua criação, deve-se retornar a matematização e alterar ou ajustar as hipóteses.

Do ponto de vista de Barbosa (2001, p.4), nem a matemática e nem a modelagem são "fins", mas sim "meios" para questionar a realidade vivida, pois elas permitem aos alunos criarem algum nível de crítica, não complexas análises sobre o mundo social. A modelagem permite aos alunos buscarem soluçóes para situaçóes-problemas de outras áreas não matemáticas utilizando a matemática.

Podemos verificar situaçóes no cotidiano que envolvem modelagem matemática e classificá-las, não necessariamente à modalidade de projetos. Barbosa (2001), por meio de análise dos estudos sobre modelagem, nacional e internacional, classificou os casos de modelagem de três formas diferentes:

Caso 1: O professor apresenta a descrição de uma situação-problema, com as informaçóes necessárias à sua resolução e o problema formulado, cabendo aos alunos o processo de resolução. Não é necessário que eles procurem dados fora da sala de aula, todo o trabalho se dá a partir da situaçáo e do problema oferecido pelo professor.

Caso 2: O professor traz para a sala um problema de outra área da realidade, cabendo aos alunos a coleta das informaçóes necessárias à sua resolução. Eles devem buscar dados fora da sala de aula e fazer algumas simplificaçóes que ajudem a resolver o problema.

Caso 3: A partir de temas não-matemáticos, os alunos formulam e resolvem problemas. Eles também são responsáveis pela coleta de informações e simplificação das situaçóes-problema, contando sempre com a colaboração e orientação do professor quando solicitado.

A utilização da modelagem matemática como prática de ensino pelo docente que ainda é inexperiente nessa área deve ser realizada com cautela e abordar conteúdos que o mesmo tenha domínio. Burak (1992, p. 292), aconselha a trabalhar com um tema, decidido em conjunto com a classe, procurando sempre aquele a que seja mais significativo para ela. Aos que já possuem mais experiências, podem permitir maior liberdade de escolha 
dos temas por parte dos alunos, agindo apenas como mediador do processo ensino-aprendizagem durante todo o período de criação do modelo.

Optamos, ao realizar a pesquisa, pelo conceito de modelagem matemática utilizado por Barbosa para descrever o caso 1, no qual apresentamos situaçôes-problemas já formuladas para que os alunos encontrassem apenas os resultados, pois seria necessário uma disponibilidade maior de carga horária para desenvolver um modelo a partir de uma situação-problema apresentada ou desenvolver todo o processo de criaçáo de um modelo matemático, desde a escolha do tema a ser abordado por eles até sua solução. Mesmo os alunos sendo responsáveis apenas pela parte de encontrarem as soluçóes, todos os processos até esta etapa foram expostos a eles.

\section{Metodologias utilizadas na pesquisa: engenharia didática e estudo de caso}

As metodologias de pesquisa que foram utilizadas neste trabalho são a Engenharia Didática e Estudo de Caso, e a instituição escolhida para realizar as atividades de pesquisa e as observaçóes metodológicas, foi o Centro de Educação de Jovens e Adultos Alternativo do município de Juína, através do acompanhamento e observação das aulas da disciplina de Matemática do ensino médio.

Na utilização dos dois tipos de pesquisa, buscamos em Almouloud (2007) a Engenharia Didática e em Gil (2010) O Estudo de Caso como orientação teórica no desenvolvimento desta pesquisa.

Engenharia Didática é caracterizada por um esquema experimental e também como pesquisa experimental na qual o pesquisador tem por base a construção, realização, observação e análise de sessôes de ensino tendo como modo de validação a comparação entre análise a priori e análise a posteriore, ela se encaixa no modelo de pesquisa proposto neste projeto, onde visa verificar se modificando a didática de ensino obtém-se melhores resultados no aprendizado dos alunos, como dito por Almouloud (2007, p.171).

A engenharia didática pode ser utilizada em pesquisas que estudam o processo de ensino e aprendizagem de um dado objeto matemático e, em particular, a elaboração de gêneses artificiais para um dado conceito. Esse tipo de pesquisa difere daqueles que são transversais aos conteúdos, mesmo que o suporte seja o ensino de um certo objeto matemático (um saber ou um saber-fazer). (ALMOULOUD, 2007, p.171). 
A metodologia da engenharia didática possui algumas fases, são elas: as análises prévias, construção das situaçóes e análise a priori e, experimentação, análise a posteriori e validação.

$\mathrm{Na}$ fase das análises prévias, um dos objetivos é identificar os problemas de ensino e aprendizagem do objeto de estudo e delinear de modo fundamentado as questôes, as hipóteses, os fundamentos teóricos e metodológicos da pesquisa. Elas devem permitir ao pesquisador a identificação das variáveis didáticas potenciais que serão especificadas e manipuladas nas fases seguintes.

Durante a construção das situaçóes e análise a priori, o pesquisador deve elaborar e analisar uma sequência de situaçóes-problemas (escolha de questóes abertas e/ou fechadas numa situação mais ou menos matematizadas). Sua principal função é a utilização implícita, e depois explícita, de novos objetos matemáticos, por meio de questôes colocadas pelos alunos no momento da resolução do problema. Já o objetivo de uma análise a priori é determinar como as escolhas efetuadas permitem controlar os comportamentos dos alunos e explicar seu sentido, ela é importantíssima, uma vez que, é de sua qualidade que depende o sucesso da situação-problema.

A fase da experimentação é onde se coloca em funcionamento tudo o que foi construído nas fases anteriores, corrigindo quando as análises locais do desenvolvimento experimental identificam essa necessidade. Ela é seguida da fase de análise a posteriori que se firma no conjunto de dados recolhidos durante a experimentaçáo e podem ser complementados pelos dados obtidos pela utilização de metodologias externas como, questionários, entrevistas individuais ou em pequenos grupos. O objetivo é relacionar as observaçóes com os objetivos definidos a priori e estimar a reprodutibilidade e a regularidade dos fenômenos didáticos identificados.

Assim, a pesquisa baseou-se em um primeiro momento de observação da didática aplicada para exposição do conteúdo de função afim e desenvolvimento de atividades propostas, seguido pela aplicação de um teste para avaliar o aprendizado dos discentes. Num segundo momento será exposto o mesmo conteúdo de função afim através da modelagem matemática, buscando uma melhor interação dos alunos com o tema e, aplicaçáo de um novo teste, que terá como finalidade a comparação com o anterior para o desenvolvimento dos resultados finais.

Já o Estudo de Caso consiste no estudo profundo e exaustivo de um ou poucos objetos, de maneira que permita seu amplo e detalhado conhecimento, tarefa praticamente impossível mediante outras metodologias de pesquisa. Seus propósitos são o de proporcionar uma visão global do problema ou de 
identificar possíveis fatores que o influenciam ou são por ele influenciados. (GIL, 2010, p.38).

Como na engenharia didática, o estudo de caso também possui um conjunto de etapas que são seguidas na maioria das pesquisas desse modelo. Gil (2010, p.117) as classificam como: a) Formulação do problema ou das questôes de pesquisa; b) Definição das unidades-caso; c) Seleção dos casos; d) Elaboração do protocolo; e) Coleta de dados; f) Análise e interpretação dos dados; g) Redação do relatório.

\section{Por entre os resultados da pesquisa}

A pesquisa foi realizada com uma amostra de 10 alunos que cursam o Ensino Médio, turma A do CEJA, durante o período matutino. A turma é composta por alunos que concluíram o ensino fundamental e se inscreveram para o ensino médio, provenientes do ensino regular ou da própria EJA. Não podemos classifica-la como $1^{\circ}, 2^{\circ}$ ou $3^{\circ}$ ano, pois o ensino médio desde 2017, teve uma nova organização pela SEDUC, devido a baixa demanda e passou a ser oferecido através de carga horária por disciplinas. Dois alunos não responderam, um optou por não participar e o outro não conseguiu desenvolver nenhum dos exercícios, nos gráficos eles serão contabilizados como erros.

O pré-teste foi aplicado no dia 23 de novembro de 2017, sendo primeiramente exposto o conteúdo de função afim através de aula tradicional (conceito e exemplos) das 07:00 as 09:00 horas e após o intervalo foi entregue o questionário para resoluçóes de forma individual e sem consultas.

Podemos observar nas questóes de 1 a 4 aplicadas no pré-teste, que são questóes típicas em aulas tradicionais de função afim, onde seu método resolutivo ocorre por meio de substituição dos valores informados e operaçóes inversas para encontramos os valores solicitados para a variável ou (). São questão não fundamentadas em situaçóes-problemas reais ou fictícias, o que não permite uma contextualização com o cotidiano do aluno, dificultando assim a obtenção de uma melhor compreensão por parte dos mesmos. 


\section{Ilustração 1 - Questões}

Considerando a função $f$, dada por $f(x)=-3 x+1$, calcule $f(-2)$.

Dada a função $f(x)=2 x+4$, determine x para $f(x)=-6$.

Calcule o valor de $f(x)$, quando $x=-3$ da função definida por $f(x)=-5 x-2$.

Dada a funçáo $\mathrm{f} \operatorname{com} f(x)=3 \mathrm{x}-1$, determine $f(3)-f(2)+f(0)$.
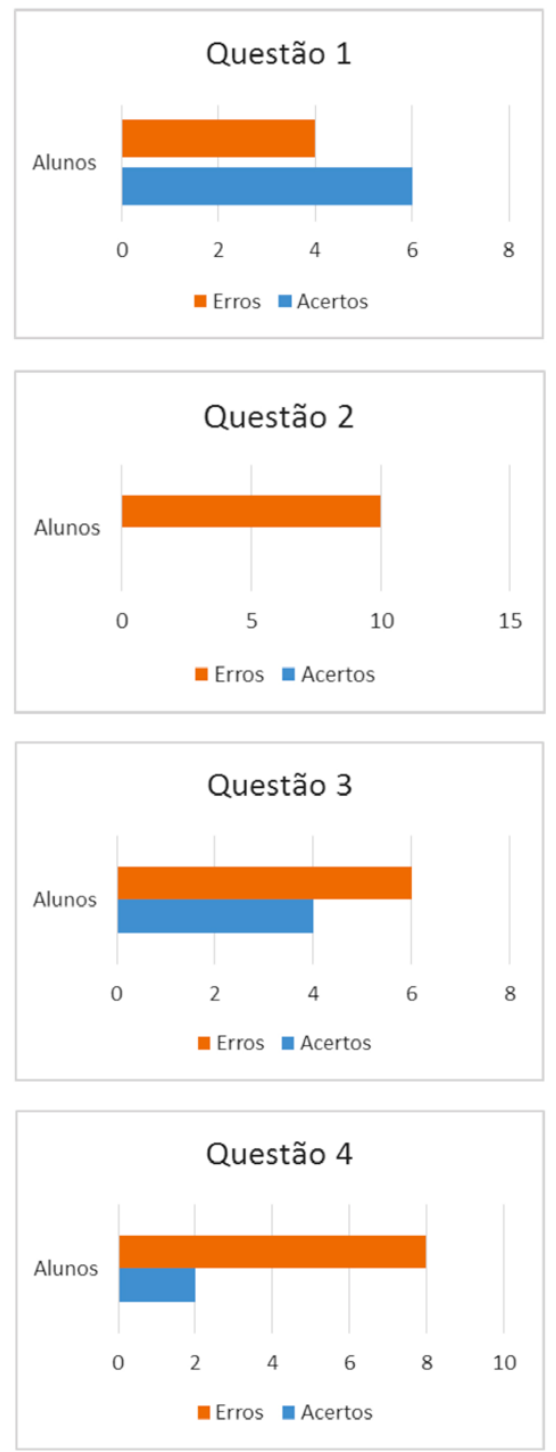

Fonte: 0 autor. 
Na questáo 1, por se tratar da substituição da variável, pelo valor solicitado e desenvolver o cálculo de forma direta houve o maior índice de acerto. Os erros verificados foram ocasionados por problemas com "jogo" de sinais.

$\mathrm{Na}$ questáo 2, houve $100 \%$ de erros. Os motivos foram os mesmos, substituíram o valor da variável $x$ e calcularam de forma direta, sendo a resposta a ser obtida a partir da funçáo dada com a igualdade proposta utilizando-se de operaçóes inversas para obter o valor da variável solicitada.

$\mathrm{Na}$ questáo 3, o índice de erros foi superior ao de acertos, também ocasionados pelo "jogo" de sinais entre a multiplicaçáo e até mesmo na soma de números positivos com números negativos.

Na questão 4, a dificuldade verificada foi na realização do cálculo final, que seria obtido a partir da expressão numérica a ser calculada utilizando os resultados parciais de cada valor informado para a variável $x$ através da função dada. Verificamos também erro na multiplicação de um numero por zero, onde os resultados obtidos foram números diferente do zero e dificuldade nas operaçôes com sinais opostos.

A segunda parte do pré-teste foi composto por questóes que envolvem situaçóes-problemas. Essas questôes geralmente são aplicadas pelos docentes como uma parte introdutória do conteúdo de Funçôes, antes dos conceitos e definiçóes, mas sem um aprofundamento com a realidade dos alunos, sem contextualiza-la com o seu dia-a-dia e sem os induzir a reflexão de como ela está presente no seu cotidiano em diversas situações, como por exemplo, no consumo de energia, de telefone, da água e do gás.

Os resultados obtidos foram negativos, pois para as resoluçóes desses tipos de questôes é necessário primeiramente uma interpretação da situaçãoproblema apresentada, para em seguida buscar formas de resolvê-las.

$\mathrm{Na}$ amostra analisada apenas um aluno conseguiu interpretar o problema apresentado e resolvê-lo. Outros dois tentaram, mas não conseguiram e o restante a partir da questão 5 desistiram de responder, alegando serem perguntas muito difíceis de interpretarem para conseguirem formular uma maneira de atingirem a soluçáo final.

$\mathrm{Na}$ semana seguinte foi aplicado o pós-teste, com a mesma forma de aplicação do pré-teste. O teste foi aplicado após o intervalo para um total de 8 alunos, pois alguns já haviam encerrado sua carga horária na disciplina de matemática.

Primeiramente, foi exposto aos discentes o significado do termo modelagem matemática e como por meio dela poderíamos transformar situaçóes do cotidiano em situaçóes matemáticas. Foi ministrada uma aula de resoluçóes 
de problemas, que envolviam modelos matemáticos já existentes de função afim, ensinando aos alunos interpretarem as situaçóes-problemas e resolvê-las.

Como primeiro exemplo, utilizamos uma situação de consumo de água, onde até um determinado valor de metros cúbicos gastos era cobrado apenas a taxa de consumo e após exceder esse valor tinham-se valores a serem acrescidos ao total a pagar, o que despertou bastante a curiosidade dos alunos, pois a maioria utilizam água do departamento da cidade e possuem faturas mensais a pagar.

No segundo exemplo, a situação-problema era baseada na produção de parafusos de uma fábrica, particularmente sobre o preço de custo de cada um com base no diâmetro da sua base. A partir, daí então desenvolver cálculos sobre o valor pago a uma determinada quantidade de parafusos com determinado diâmetro. Sentiram-se um pouco desconfortável, devido apresentarem muita dificuldade em cálculos com números decimais.

E por último, em um terceiro exemplo, abordamos a problemática de um caminhão de frete, que cobrava uma taxa fixa por viagem além de um custo adicional por quilometro rodado. Desenvolvendo cálculos através de um determinado valor pago por um cliente e também tendo apenas a distância entre dois pontos distintos, uma situaçáo bastante comum em nossa cidade.

O questionário foi composto de questóes resolutivas e dissertativas sobre as aulas ministradas e a educação de jovens e adultos. Observamos que $80 \%$ dos alunos consideram a didática de ensino da matemática por meio da modelagem mais eficiente que a didática tradicional. Apenas dois alunos preferiram o modelo de aula tradicional, pois acharam muito complicado ter que interpretar a situação-problema antes de partir para os cálculos, o restante acha interessante, pois muitas situaçóes que achavam não existir aplicação matemática, ela está sempre presente.

Abaixo um exemplo das questóes problemas que foram apresentadas:

Na produçáo de peças, uma fábrica tem um custo fixo de $\mathrm{R} \$ 200,00$ mais um custo variável de $\mathrm{R} \$ 1,20$ por peça produzida.

Qual o custo de produção de 10.000 peças?

Quantas peças podem ser produzidas com R \$20.000,00?

Percebemos que houve um maior índice de acerto no item a e, que mesmo sem os alunos terem uma lei de formação já pré-apresentada conseguiram obter o resultado correto. Já no item b a proporçáo de acertos e erros foram às mesmas, por ser tratar de uma questáo que envolve um pouco de interpretaçáo e necessita de um processo contrário ao já acostumado calculo direto de uma função. 
Em um dos questionamentos verificamos que os alunos foram unanimes em relação a matemática estar presente em sua profissão, mesmo no caso das donas de casa. Houve muita argumentaçáo de que a matemática está presente em tudo, nas contas simples, desde a dosagem de um determinado produto de limpeza em água até na fabricação de pães caseiros. Uma aluna argumentou sobre utilizar muito a matemática em costuras para calcular a medida do comprimento e da largura das roupas.

\section{Considerações finais}

A análise dos dados obtidos permite visualizar uma melhora entre os resultados alcançados com o pré-teste e o pós-teste, e consequentemente podemos ver que as opinióes dos alunos da EJA são favoráveis a essa abordagem diferenciada, como forma explicativa e expositiva de conteúdo, podendo assim, ela ser utilizada não apenas para o conteúdo pertinente ao tema deste trabalho, mas também a qualquer outro pertencente à disciplina da matemática.

Diante do exposto nos resultados e fundamentação teórica, pode-se observar que com o uso da técnica de complementação didática, no caso, a modelagem matemática, o ensino de função afim aplicado por meio da resolução de problemas que envolvem situaçóes-problemas no ambiente de aprendizagem, tem o propósito de desenvolver no discente pensamento estratégico, senso lógico e instigar sua busca por conhecimento com o objetivo de prepará-lo para situaçóes desconhecidas que estaráo presentes na esfera escolar/acadêmica e no seu dia a dia.

Por fim pode-se perceber com este estudo que os alunos tiveram uma melhora quando aplicado a metodologia da modelagem matemática, o que nos leva a crer que a maioria dos alunos estão preparados para uma nova abordagem em sala de aula, e que com técnicas científicas é possível ensinar de uma forma dinâmica, utilizando situaçóes do dia a dia onde o aluno pode pôr em prática não somente dentro do ambiente escolar, mas também fora dele.

\section{Referências}

ALMOUlOUD, Saddo A. Fundamentos da didática da Matemática. Curitiba. PR: Editora UFPR, 2007.

BARBOSA, Jonei Cerqueira. Modelagem na Educaçáo Matemática: contribuiçóes para o debate teórico. In: REUNIÃO ANUAL DA ANPED, 24., 2001, Caxambu. Anais... Rio de Janeiro: ANPED, 2001. 1 CD-ROM. 
BARBOSA, Jonei Cerqueira. Modelagem matemática: o que é? por que? como? - Veritati, n. 4, p. 73- 80, 2004.2. Disponível em: http://joneicb.sites. uol.com.br/publi.html. Acessado em: 02 de abril 2018.

BASSANEZI, Rodney C. Modelagem matemática uma disciplina emergente nos programas de formação de professores. Biomatemática IX, 1999.

BIEMBENGUT, Maria Salett; HEIN, Nelson. Modelagem matemática no ensino. 5. ed. São Paulo: Contexto, 2014.

BURAK, Dionísio. Modelagem matemática: ações e interaçôes no processo de ensino-aprendizagem. 1992. 130 f. Trabalho de Conclusão de Curso (Tese) - Curso de Psicologia da Educaçáo, Faculdade de Educação da Universidade Estadual de Campinas. Campinas, 1992.

DICIONÁRIO ETIMOLÓGICO. Disponível em: http://www. dicionarioetimologico.com.br/matematica. Acessado em: 08 de abril 2018.

FONSECA, Maria da Conceição Ferreira Reis. Educaçáo Matemática de Jovens e Adultos: especificidades, desafios e contribuiçóes. 2. ed. Belo Horizonte: Autêntica, 2007.

GIL, Antônio Carlos. Como elaborar projetos de pesquisa. 5. ed. São Paulo: Atlas, 2010.

OLIVEIRA. Samara Torres de; BITENCOURT. Loriége Pessoa. O ensino de Matemática na educaçáo de jovens e adultos na perspectiva dos professores. Revista Eventos Pedagógicos, v. 6, n. 2, p. 416-431, jun/jul. 201 


\section{PARTE III \\ ITINERÁRIOS FORMATIVOS E \\ ESPAÇOS ESCOLARES}




\section{HOMOFOBIA NA RELAÇÃO DISCENTE/DOCENTE: UM ESTUDO NA REGIÃO CENTRO-OESTE BRASILEIRA}

Neil Franco

\section{Introdução}

Desde sua criação, ocupando um lugar representativo como instituição social, a escola tem como objetivo o ensino, a aprendizagem e a manutenção dos diversos valores que constituem a sociedade em que ela está inserida. Dentre seus valores, a forma como homens e mulheres devem viver suas sexualidades e construir seu gênero constituem-se de aprendizados naturalizados e muitas vezes imperceptíveis, a partir de formas aceitáveis socialmente, desde que essas vivências e construção não tenham suas fronteiras ultrapassadas ou em trânsito.

Avançando nessa linha de raciocínio, ccompreendo a sexualidade como inserida na condição humana de forma ontológica, ou seja, uma manifestação que é inerente a todos e a cada ser humano em particular, constituindo uma das dimensóes privilegiadas de manifestação subjetiva, histórica e social. (NUNES; SILVA, 2000). A sexualidade também pertence ao campo político, pois ela “[...] é 'aprendida', ou melhor, é construída, ao longo de toda a vida, de muitos modos, por todos os sujeitos." (LOURO, 1999, p. 11).

Ancorado nas contextualizaçóes de Judith Butler (2003), o gênero é entendido como uma construção cultural, isto é, a autora compreende que ele não é aparentemente fixo como o sexo ou um resultado casual definido por sua estrutura biológica, assim como ela se nega a compreender o sexo apenas como um dado da natureza. Para a autora, sexo implica desde sempre, gênero, por que se encontra matizado pelo discurso. Com isso, ela abre espaço para pensar o gênero como a interpretação múltipla do sexo, ou ainda, possibilidades de interpretar significados culturais assumidos pelos corpos sexuados, não decorrendo de um sexo propriamente dito, mas considerando que "[...] a distinção sexo/gênero sugere uma descontinuidade radical entre corpos sexuados e gêneros culturalmente construídos." (BUTLER, 2003, p. 24).

Dentro desta perspectiva, o objetivo deste estudo é refletir sobre como as relaçóes entre alunos/as e professores/as gays, travestis e lésbicas se 
processam no cotidiano escolar. Destaco que essas análises compuseram parte de uma pesquisa de Mestrado em Educação realizada nos anos de 2007 e 2008, cujo objetivo foi de compreender e problematizar aspectos da constituição identitária de professores e professoras que transitam pelas fronteiras das sexualidades e do gênero. Interessou-me particularmente discutir o que esses sujeitos que se auto-identificam como gays, travestis e lésbicas contavam de suas histórias de vida e o lugar ocupado pela profissão docente nesse processo, principalmente quando suas identidades sexuais e de gênero ${ }^{1}$ eram evidenciadas e significadas pelos diversos atores/as que compóem a escola, sobretudo o corpo docente.

Teoricamente, a pesquisa foi embasada nos conceitos de identidade e diferença, nos aspectos históricos com relação à (re)construção das identidades sexuais e de gênero e, principalmente, nas reflexóes elaboradas pela teoria queer. Essa teoria, estruturada sob uma perspectiva pósidentitária, propóe pensar as identidades que se constituem a partir de diferentes manifestaçóes das sexualidades e do gênero por suas ambiguidades, multiplicidade, fluidez, construir novos enfoques com relação à cultura, o conhecimento, o poder e a educação. (LOURO, 2004).

Como apontado por Guacira Louro (2004), questionar o binarismo heterossexualidade/homossexualidade é um dos princípios básicos da teoria queer, mas não significa enfatizar somente as identidades homossexuais. Para esta autora, é essencial visualizar, analisar e contextualizar o campo geral no qual as identidades, sexuais, gêneros, raciais ou classes, são construídas, percebendo-as necessárias e inter-relacionadas, constituindo uma realidade complexa e em constante movimento. Para Tomaz Tadeu da Silva (2007), isso implicaria ultrapassar as hipóteses da construção social da identidade, radicalizando a possibilidade de se transitar por entre as fronteiras identitárias, bem como desencadear um possível cruzamento entre elas.

Como metodologia, a pesquisa utilizou fontes bibliográficas, análise de entrevistas, de questionários e de documentos oficiais que abordam a inserção das discussôes sobre sexualidades e gênero no contexto escolar. As entrevistas foram realizadas com seis professores e professoras: três gays,

1 Ancorado nas reflexões de Guacira Louro (1997), sob a perspectiva dos estudos culturais, defino como identidade sexual a possibilidade de se viver a sexualidade com parceiros do sexo oposto, do mesmo sexo, dos dois sexos ou sem nenhum deles, denominadas, assim, como heterossexualidade, homossexualidade ou bissexualidade. As possibilidades de constituiçáo e identificaçáo como masculino ou feminino definindo os sujeitos social e culturalmente como homem, mulher, travesti e transexual seria, como classifico, identidades de gênero. 
duas travestis e uma lésbica. Sujeitos que desempenhavam a profissão docente nas séries entre a fase introdutória e o pré-vestibular, em escolas das redes municipal, estadual e privada da cidade de Uberlândia-MG, no período no qual se realizou a pesquisa. Nas entrevistas procurei identificar como esses/as docentes construíram suas trajetórias de vida, a partir de a relação com a família, passando pela escola, pela universidade, até a definição e atuação profissional como docente. Nesses contextos, enfatizo, principalmente, como suas identidades sexuais e de gênero se inseriam nessas construçóes.

Os questionários foram aplicados em três escolas da rede municipal de Uberlândia, nas quais três desses sujeitos trabalhavam no segundo semestre de 2007. A utilização desse instrumento permitiu identificar as concepçóes de setenta e três educadores/as sobre sexualidades e (homos) sexualidades e o lugar da escola como um espaço para se inserir e contextualizar essas questóes. Os/as setenta e três docentes envolvidos nesta fase da investigação se encontravam com idade entre 25 e 45 anos (74\%) e eram, em sua maioria, do gênero feminino $(91,8 \%)$, de identidade sexual heterossexual $(94,5 \%)$, casados/as $(52 \%)$ e de cor branca $(63 \%)$.

Em decorrência do objetivo de compreender e problematizar aspectos da constituição identitária de professores e professoras gays, travestis e lésbicas, investi na afirmativa de que sua presença na escola provocava, em algum momento, questionamentos com relação às restriçôes para se discutir a diversidade sexual e de gênero na escola. Com isso, pareceu-me importante analisar os documentos oficias que contemplavam (homo) sexualidades e gênero como conteúdos a serem trabalhados no contexto escolar, para identificar que tipo e o nível de respaldo legal envolvia essa discussão. Cinco documentos foram analisados: Parâmetros Curriculares Nacionais (1997), PCN-10; o Manual do Multiplicador Homossexual (1996); o folder A travesti e o educador: respeito também se aprende na escola (2001); o Programa Brasil Sem Homofobia (2004); e a cartilha Educando para a Diversidade: como discutir homossexualidade na escola (2005).

Retomando o foco deste artigo - refletir sobre como se processa no cotidiano escolar as relaçóes entre alunos/as e professores/as gays, travestis e lésbicas -, tratarei, inicialmente, dos aspectos históricos, sociais e culturais definidores da homofobia e, em seguida, apresentarei as análises realizadas a partir do material empírico construído pelas entrvistas e, em alguns momentos, entrecruzadas pelo conteúdo dos quesionários. 


\section{Uma patologia social: homofobia}

Preconceitos e discriminaçóes têm acompanhado a história da homossexualidade e a aversão social destinada a essa manifestação afetivosexual foi denominada cientificamente como homofobia. O termo foi criado pelo psicólogo George Weinberg em 1971, resultado da uniáo de duas palavras gregas phobos (fobia) e o prefixo homo (remetendo à palavra homossexual) ${ }^{2}$. Para Bruce Hilton (1992), a homofobia é uma doença contagiosa universal que nos acomete desde criança e tem como principal transmissor a pessoa adulta. Culturalmente considerada natural, faz com que sua presença seja quase imperceptível. Seus efeitos vão do desagrado à fúria, do julgamento à obsessão e, em estágios mais virulentos, fez com que nos Estados Unidos, entre as décadas de 1980 e 1990, uma média de cem homossexuais fossem assassinados/as anualmente e, ainda, que outras mil pessoas atacassem gravemente homossexuais, resultando em hospitalizaçóes dessas vítimas. Outro estudo feito pelo governo federal dos Estados Unidos também confirmou que o suicídio entre adolescentes homossexuais era de duas a três vezes mais freqüente comparado a adolescentes não homossexuais - dados que ainda perduram e são bem similiares aos descritos no Brasil nos tempos atuais.

Algumas referências teóricas são unânimes na afirmativa de que a homofobia seja uma doença anti-social comparada ao machismo e o racismo. O Manual do Multiplicador Homossexual (1996) ressalta que a cura da homofobia se dá com a informação e a punição das pessoas que desrespeitam os direitos humanos de homossexuais.

De acordo com o Relatório anual 2005, realizado pelo Grupo Gay da Bahia ${ }^{3}$ sobre os assassinatos de homossexuais no Brasil, entre os anos de 1963 e 2005 foram registrados 2.582 assassinatos de gays, lésbicas e travestis, alcançando valores mais expressivos em 2004, quando o registro atingiu 158 assassinatos. O menor índice ocorreu em 2005, com um total de 81 assasinatos. Dos assassinatos no ano de 2005, 56 eram gays, 24 travestis e uma era lésbica e a maior incidência desses crimes se deu nas duas grandes capitais do país, 12 no Rio de Janeiro e 9 em Sáo Paulo. Em 2017, os registros divulgados pelo GGB informam 445 mortes, sendo em maior número gays e pessoas trans,

2 Disponível em: pt.wilipedia.org/wili/homofobia\#origem_e_significado. Acessado em: 09 de agosto 2014.

3 Disponível em: www.ggb.org.br/assassinatos2005c.html. Acesso em: 01 de junho 2014. 
seguido de lésbicas e um baixo número de bissexuais. A maior incidência desses assassinatos ocorreram no estados de São Paulo, Minas Gerais, Bahia e Ceará .

Não nascemos com aversão à homossexualidade, tal aversão é um aprendizado que varia de acordo com a cultura de cada sociedade. Conta em registros históricos que a primeira lei anti-homossexual foi aprovada na Inglaterra no ano de 1553 e que o bispo John Atherton foi a primeira pessoa naquele país a ser enforcada por ser homossexual. (HILTON, 1992). Segundo Trevisan (2004), a prática homossexual era condenada à morte na Europa até 1810 e no Brasil essa lei persistiu até 1830. A partir desse período, foi-lhe atribuída pena de prisão quando praticada em público, delito que se referia a "ofensa à moral e aos bons costumes", "crime contra a segurança da honra e a honestidade das famílias" ou "ultraje público ao pudor”, permanecendo com mínimas alterações nos Códigos Penais brasileiro dos anos de 1890, 1964 e 1967.

Ao mesmo tempo, encontram-se registros de tribos norte-americanas nas quais homossexuais eram denominados/as berdaches e considerados pessoas extremamente sábias e importantes conselheiras nas tomadas de decisóes. Há referência dos/as berdaches no estudo de Gregersen (1983) e Fry e MacRae (1985). Esses últimos fazem uma descrição detalhada dos/as berdaches inclusive contam como eles/as foram obrigados/as pelos colonizadores europeus a se ajustarem ao gênero correspondente ao sexo biológico.

Diversas razóes constroem-nos culturalmente homofóbicos. Hilton (1992) nos aponta nove aspectos que justificam essa afirmativa. Os discursos que nos rodeiam desde criança é o primeiro deles. O silêncio dos pais e a relutância em falar sobre determinados assuntos é percebida pela criança e os julgamentos, as piadas e palavras ásperas referidas a certos tipos de pessoa ensinam a quem se deve ou náo respeitar. Isso também ocorre "na escola, muito tempo antes de termos qualquer idéia do que seja lésbica, gay ou homossexual, aprendemos que é permitido ridicularizar os homossexuais.” (HILTON, 1992, p. 29).

A resistência humana em aceitar o diferente, principalmente no processo de construção de nossa localização no mundo é o segundo aspecto. O terceiro refere-se à forma como as informaçóes que transitam socialmente a respeito da homossexualidade são seletivas e negativas. Os meios de informação noticiam "assassino gay", "tarado gay", entre outras notícias do mesmo cunho que se refere a heterossexuais. (HILTON, 1992).

O quarto aspecto seria o machismo que, apesar das tentativas de reverter

4 Disponível em: https://oglobo.globo.com/sociedade/assassinatos-de-lgbt-crescem-30-entre2016-2017-segundo-relatorio-22295785. Acessado em: 01 de fevereiro 2019. 
essa situação, a desvalorização feminina persiste como uma das principais tendências do pensamento ocidental. Hilton (1992) enfatizou que o aspecto mais questionável da homossexualidade, sobretudo para os homens, seria a possibilidade de o papel sexual culturalmente destinado à mulher ser assumido por um homem.

Generalizar o pensamento com relação à homossexualidade é o quinto aspecto. $\mathrm{O}$ fato é que se analisa toda a complexidade de uma relação amorosa entre duas pessoas restringindo-a a união de dois órgãos genitais, ou seja, discute-se sobre partes e não sobre pessoas. Esse enfoque distorce e banaliza as relaçóes e ignora realidades como compromisso, lealdade e ternura. Conceituar a homossexualidade como "estilo de vida" ou "preferência sexual" consiste, portanto, uma forma pejorativa de usar palavras para denominar as práticas sexuais de lésbicas e gays, já que, sob um prisma científico, o desejo afetivosexual não pode ser mais definido como escolha. Falo aqui do sexto aspecto apontado por Hilton (1992).

O sétimo aspecto apresentado pelo autor se refere à necessidade que as pessoas têm de respostas simples sobre o que está mudando constantemente no mundo, independente de qual seja ou o que possa desencadear essa resposta. $\mathrm{O}$ oitavo aspecto refere-se à forma como o anonimato faz, em muitos casos, da homossexualidade uma questão abstrata, levando gays e lésbicas a ocultar suas identidades sexuais sendo deslocados da condição de pessoa e alimentando a homofobia social.

A última razão da construção da homofobia representa nossa dificuldade de lidar com a sexualidade no aspecto geral, alimentada principalmente pela religiáo que recusa o sexo como um de seus princípios sociais. De maneira geral, os escritos da Igreja primitiva náo manifestaram interesse com a ética sexual. Esse fato aconteceu entre os três primeiros séculos da era cristã quando a Igreja distendia suas relaçóes com o Império Romano, absorvendo suas normas sexuais rígidas e o ódio ao corpo.

Os romanos haviam se apegado de uma antiga idéia dos gregos e zoroastristas. Corpo e mente são antagônicos. A mente é boa, o corpo é ruim. O pensamento é bom, a paixão é ruim. $\mathrm{O}$ homem (racional) é bom, a mulher (emocional) é ruim. A abstinência é boa, ceder às sensaçōes sexuais é ruim. (HILTON, 1992, p. 40).

Essas razóes justificam essa longa caminhada para poder acreditar no corpo como parte essencial de nosso próprio ser, mas, como adverte Hilton (1992), as ideias antigas ainda permanecem no imaginário social e, diante de dezesseis séculos 
de ambivalências, não se admira que seja tão problemático em nossa sociedade lidar com a mais complexa ambiguidade da sexualidade, a homossexualidade.

Com isso, acredito na relevância de se contextualizar as tensóes produzidas na sociedade pela homossexualidade, afinal, ela desestabiliza os princípios históricos, sociais e culturais pelos quais a condição humana foi rigidamente constituída, evidenciando que homens e mulheres, em meio a suas vivências das sexualidades e a construção de seu gênero, constroem-se socialmente e através de um constante jogo de forças ou, em outras palavras, por contraposiçóes das diversas identidades sociais.

Funcionando como uma das principais instituiçóes sociais, a escola efetivase como um desses espaços nos quais aquelas sexualidades e aqueles gêneros - que não estão em consonância com os princípios da heterossexualidade e do binarismo homem/mulher - podem causar desconfortos e tensóes nas relaçóes cotidianas estabelecidas entre os sujeitos que a integram. As análises realizadas neste estudo confirmam essa afirmativa.

\section{Marcas da homofobia na relação discente/docente}

De acordo com a abordagem de Hilton (1992), a homofobia é construída desde a infância, período no qual a criança aprende inicialmente pela educação dos pais a quem se deve ou não respeitar. Louro (1999, p. 29) confirma essa afirmativa e afirma que "meninos e meninas aprendem, também desde muito cedo, piadas e gozaçóes, apelidos e gestos para dirigirem àqueles e àquelas que não se ajustam aos padróes de gêneros e de sexualidade admitidos na cultura em que vivem". Segundo a autora, a simpatia para com sujeitos homossexuais torna-se resistente, evidenciando a aproximação a esses sujeitos como uma forma de adesão a essa prática ou identidade, efetivando nas diversas instâncias sociais e em que a escola seria uma delas, a concepçáo da homossexualidade como um fator contagioso.

Os relatos dos sujeitos dessa pesquisa confirmaram as consideraçóes de Hilton (1992) e Louro (1999). Elas/eles definiram a homofobia como uma construção que se inicia na família e, dependendo da forma como a escola lida com esse conhecimento cultural, o estigma em relação às pessoas que transitam pelas fronteiras das sexualidades e do gênero torna-se mais consistente. Brenda ${ }^{5}$, travesti, explicita esse fato em seu relato.

5 Todos os nomes utilizados para identificação dos sujeitos da pesquisa são fictícios, respeitando a determinação da Resolução 196/96, de 10 outubro de 1996, do Conselho Nacional de Saúde, que normatiza a pesquisa com seres humanos. 
Muitas vezes o problema não está no aluno, mas na família dele. Muitas vezes o aluno não é homofóbico, ele se torna porque os pais são e embutem essa característica nele. Muita coisa da nossa personalidade nós absorvemos dos pais, eles são os exemplos. Se eles questionam, o filho também vai questionar. Se eles são contra, os filhos também serão. Não estou dizendo que todo mundo deva abrir sua mente, mas a pessoa tem que aprender a respeitar. Você não é obrigado a aceitar, mas é obrigado a respeitar. Está na Constituição. (Brenda, dezembro de 2007).

O machismo foi o principal aspecto que emergiu de maneira direta ou indireta no relato dos sujeitos quando falaram dos obstáculos na relaçáo com os/as alunos/as por consequência das suas identidades sexuais e de gênero. Associada, à construção familiar e cultural, é notável a recusa para com o professor homossexual e principalmente por alunos do gênero masculino. Das oito situaçóes de discriminação manifestadas por alunos/as contra docentes homossexuais relatadas pelos/as docentes que responderam ao questionário da pesquisa, sete referiam-se a professores homossexuais e uma a ambos os gêneros. No entanto, o número de situaçóes de agressóes verbais por parte de alunos vivenciadas por Fernando foi superior às apresentadas nos questionários. Ele comentou sobre essas manifestaçóes agressivas como uma vivência frequente.

Aconteceu até esse ano, no noturno, estava saindo da sala da sexta série. Ao lado dessa sexta série tinha uma quinta série, aí, num intervalo, mudança de uma sala pra outra, esses meninos que nem eram meus alunos estavam dizendo: "Ah, o professor é veado, o professor é gay, professor é boiola. (Fernando, junho de 2007).

A professora Marina foi enfática quando a perguntei quem causava maior estranhamento aos alunos/as: o professor gay ou a professora lésbica?

Sem dúvidas, o professor, isso é nítido. Eu percebo que o adolescente passa por uma auto-afirmação da sexualidade, ele quer se provar homem, se afirmar como homem, [...] eu sinto que a presença do professor homossexual incomoda o aluno adolescente, aquele que está em fase de formação da sua identidade sexual. (Marina, agosto de 2007).

No estudo de Paredes, Oliveira e Coutinho (2006, p. 63), realizada com alunos/as das escolas públicas na cidade de Cuiabá, Mato Grosso, a recusa à homossexualidade masculina manifestada por adolescentes do gênero masculino foi evidenciada quando as autoras analisavam os conteúdos das falas 
de sujeitos referentes às possibilidades de comportamentos sexuais de gênero. essas autoras identificaram que sujeitos "reportavam-se ao modelo ideal de homem, exigido como aquele másculo, forte, provedor, viril, como é visto pelo modelo tradicional; e, ao de mulher como aquela que mantém o ideal de procriação." O estudo realizado por Abramovay; Castro; Silva (2004, p. 303) também evidenciou essa afirmativa. Constataram que a agressão física contra homossexuais foi indicada como um tipo de violência pouco representativa para os adolescentes do gênero masculino que participaram da pesquisa:

Quando solicitados a indicar cinco das formas mais graves de violência, rapazes e moças selecionam os mesmos itens, mas com uma singular exceção: a questáo da agressáo a homossexuais.é bater em homessexuais classificado pelas jovens como a terceira violência mais grave, enquanto que para os rapazes ela ocupa a sexta posição. (grifos no original).

Para maioria dos sujeitos, a presença da professora homossexual na escola não causava estranhamentos aos/às alunos/as. Segundo Fernando, se os/as alunos/os faziam algum tipo de comentário sobre as professoras lésbicas seria indiretamente, diferente do que acontece com ele e outros professores gays que conhecia. Marina esclareceu que no universo feminino não existe a necessidade de uma autoafirmação da feminilidade, consequentemente a relação entre o/a aluno/a com a professora homossexual acontece de maneira tranquila.

[...] porque o adolescente tem muito medo de ser rotulado como gay, fica se auto-afirmando que ele é macho, que ele é macho, falando cinqüenta vezes que ele é macho, agredindo o colega para mostrar sua masculinidade. A mulher não, a mulher é muito tranqüila, é carinhosa com as colegas, carinhosa com a professora, então, ela não fica se autoafirmando que é mulher. (Marina, agosto de 2007).

João comungou a mesma opinião de Marina. Renato confirmou que a convivência é tranquila com a presença de professoras lésbicas no contexto escolar, apontando até um processo de invisibilidade desses sujeitos, fato também evidenciado por Rogéria que afirmou não perceber a presença de professoras lésbicas, mas acreditava que sua relação com alunos/as ocorresse sem conflitos. Essas percepçóes remetem-nos a um dos aspectos da construçáo cultural do lesbianismo que, estando diretamente relacionada à inferioridade historicamente atribuída ao gênero feminino, atribui para as manifestaçóes afetivo-sexuais entre mulheres a condição da invisibilidade social. (SWAIN, 2007). 
Brenda divergiu da opiniáo dos demais sujeitos e afirmou nunca ter atuado profissionalmente com professoras lésbicas. Para ela, esses sujeitos são vítimas de maior discriminação por parte dos/as alunos/as comparado aos professores gays que, de acordo com sua percepçáo, ganham espaço na escola com o passar do tempo. Sua opiniáo parece representar a concepçáo da negaçáo social do lesbianismo como uma prática humana na qual as lésbicas são consideradas como uma caricatura masculina ou a representação da mulher frustrada, desprovida de beleza e feminilidade. (SWAIN, 2007).

Sobre a recusa permanente da homossexualidade masculina, todos os relatos apontam para a predominância do modelo grego de sexualidade apresentado por Weeks (1999) que evidenciam a heteronormatividade como definidora das atribuiçóes históricas, sociais e culturais de gênero representadas na concepção patriarcal de sociedade ocidental na qual estamos inseridos.

Glorianne Lek (2005) definiu o patriarcado como um sistema de poder estruturado pela hiper-valorização do masculino com relação ao feminino, ou seja, a identidade de gênero é o fator definidor da valorização da condição humana, ou seja, em função do sexo biológico, os seres humanos são divididos em dois grupos sociais de gênero, cada qual com papeis a cumprir e poderes pré-determinados. Neste sentido, a autora afirma que quando um homem se feminiza é, em geral, castigado socialmente. Esse processo de repressão da homossexualidade, sobretudo da masculina, representa uma dinâmica de poder culturalmente construída e a manutenção do sistema de valores patriarcais que, para Lek (2005), torna-se ameaçado pela adoção de atitudes ou condutas femininas por homens, porque, de certa forma, exprime a possibilidade de eqüidade entre os gêneros.

Neste contexto, retomo as reflexóes realizadas por Hilton (1992) afirmando que a desvalorização da feminilidade é uma das principais tendências do pensamento ocidental, palavras que são coniventes com a problemática em questáo.

Assim, não deve ser surpresa que, para muitos homens, o aspecto mais questionável do homossexualismo masculino é que um dos homens pode - mas não necessariamente - assumir um papel 'feminino'. Um homem rebaixandose deliberadamente, agindo como uma mulher! Também náo deve constituir surpresa o fato de que pais se sentem muitíssimo mais ameaçados do que as mães pela ideia de ter um filho homossexual. O estereótipo de um homem efeminado - ou, pior ainda, de um homem sendo o parceiro passivo (feminino) num ato sexual - é o suficiente para deixar com pressão alta qualquer homem heterossexual 
norte-americano que adora futebol, musculação e armas de fogo. (HILTON, 1992, p. 34-35, grifos do autor).

A postura enérgica de Renato perante os/as alunos/as evitava que sua identidade sexual fosse questionada por eles/as. A efetiva participaçáo em atividades culturais do movimento negro em Uberlândia que lhe proporcionava popularidade, tornando-o conhecido nas escolas em que trabalhou, foi também uma justificativa apresentada sobre essa questão. No entanto, algumas situaçóes de estranhamento por parte de alunos/as por causa da sua identidade sexual já ocorreram em espaços da escola, mas que, em sua opiniáo, não podem ser classificadas como agressão.

Com alunos, pode ser que um aluno que não seja de minhas turmas, lá na hora da saída, 'olha o professor boiola’. Aquilo também você ignora. Os outros mesmos já chamam a atenção dele, amanhã já não acontece isso mais, que, para mim, eu considero também normal. Até mesmo você olhar a pessoa não como simplesmente um objeto, mas como alguém que pode, amanhã, ser seu professor. (Renato, agosto de 2007).

Brenda não apontou obstáculos na relação com os/as alunos/as de nenhuma escola na qual trabalhou. No primeiro encontro com suas turmas costuma esclarecer os aspectos de sua identidade de gênero e demarcar os limites das relaçóes que serão estabelecidas e mencionou manter laços de respeito e afeto com seus/as alunos/as.

Piadinha em sala de aula, se ocorrer, é no primeiro dia, coisa que não ocorre, porque quando entro pela primeira vez na sala de aula gasto quase quinze minutos explicando quem eu sou, o que faço e o que fiz. 'Estáo aqui as normas, me respeite e eu te respeito.' E tem um respeito muito grande. Eu sempre adoto uns três ou quatro, que grudam no meu pé literalmente. Você puxa, não adianta, e graças a Deus, vamos supor, numa sala de 40 , quando eu não agrado a todos, desagrado um ou outro, no máximo dois. (Brenda, maio de 2007).

Os relatos de Renato e Brenda nos conduzem a outro campo da discussão, que me leva a arguir quais as estratégias que esses sujeitos adotam quando suas identidades sexuais e de gênero são questionadas pelos/as alunos/as dentro da escola. Para Fernando, João, Rogéria e, como explicitou Brenda acima, o fato de assumir-se e questionar seu lugar como pessoa humana e profissional desencadeiam, na maioria dos casos, um processo de acomodação das agressóes e até mesmo o estabelecimento de novos laços na relação entre os sujeitos. 
A intervenção imediata é a estratégia utilizada por João nos momentos em que sua identidade sexual é questionada de maneira pejorativa, desencadeando um processo de reflexáo sobre o papel do professor, do aluno e sobre a agressão ocorrida. A intervenção que realizou com um aluno do primeiro ano colegial recém-chegado à escola que trabalhava foi um exemplo claro.

Esse aluno foi muito bem acolhido, muito bem recebido, a turma também e, após duas ou três aulas, num momento que eu estava dando aula e passei a explicaçáo no quadro, no que eu fiz o movimento de virar para o quadro, eu percebi quando ele chegou próximo ao colega do lado e lhe disse: 'Esse cara é viado.' Eu percebi e é um tipo de oportunidade que eu náo perco, náo perco. Naquele momento, me virei para ele e disse: 'Não era bem esse o termo que eu gostaria que você se referisse a mim, mas já que foi esse o termo que você usou e, é assim que você pensa, sou mesmo e isso não lhe diz respeito. Eu quero saber se eu sou um professor de Química competente ou năo. Isso sim lhe interessa. Daí para frente, nada mais te interessa.' Ele respondeu: 'Náo, por favor, me desculpe, não era isso que eu queria dizer.' Eu falei: 'Depois, se você quiser e achar necessário, podemos conversar.' $E$ foi o que aconteceu. A aula acabou e ele veio conversar e me pediu desculpas. Disse-lhe que isso não interessava mesmo, nós fechamos a discussão e pronto. Hoje, talvez, ele seja um aluno que eu vou chegando na sala e ele está na porta para me receber. $\mathrm{O}$ quadro está sujo, ele é o primeiro a apagar. Entáo, você tem que educar também, você não pode agir de forma passiva: 'Oh, nossa, ele sabe de tudo.' E daí? Em que isso vai afetar o nosso trabalho? (João, agosto de 2007).

As relaçóes de poder e resistência estão expressas neste relato. Um poder legitimado histórico, social e culturalmente à identidade consagrada como a única e possível que lhe permite desprezar e depreciar a identidade concebida como inferior ou anormal. No entanto, a partir da resistência manifestada por João, esse poder se desloca e se desestabiliza impondo a estruturação de novas formas de representaçóes de poder.

Assim como João, Rogéria apontou que os alunos ingressantes na escola, principalmente do primeiro ano do ensino médio, são os que manifestam maior estranhamento com relação a sua identidade de gênero, chegando até mesmo a influenciar outros alunos com os quais mantinha uma convivência tranquila. 
Quando eu pego um aluno que nunca me viu, aí começa aquelas piadinhas: 'Ah, o professor boiola. Ah, o professor viado. Ah, o professor está virando mulher.' E, se for um aluno líder dentro da sala de aula, como eu já tive, ele não me conhecia e me odiava, tinha pavor da minha cara. Então, até aquele aluno que tinha uma admiração por mim se afastou por causa desse aluno que era líder. Aquela faixa de 14 e 15 anos eles têm uma afirmação muito grande da sexualidade deles, querem provar que são homem de qualquer forma. O fato de ter amizade com uma 'bichona', como eles falam, boiola, gay, poderia influenciar na masculinidade deles, mas é só isso, passando essa fase dos 15, 16 anos, eles voltam a conversar normal. (Rogéria, julho de 2007).

Como já foi abordado linhas atrás, a professora homossexual não desencadeia a mesma atenção para os/as alunos/as como ocorre com o professor homossexual. Marina, no entanto, relatou que alunos/as já lhe perguntaram sobre sua identidade sexual, mas em nenhuma situação, de forma agressiva. Segundo ela, a abertura para esse diálogo somente ocorreu e ocorre quando o interlocutor é um/a aluno/o maduro/a e que com o/a qual tenha um bom relacionamento.

Com os adolescentes eu não entro muito em detalhes, mas, é assim: 'Você tem namorado? Você gosta de homem? Não sei o que.' Eu levo na brincadeira. Sou autêntica, assumida, não fico escondendo, mas, não sou de ficar expondo demais para os alunos. Para os colegas sim, mas para os alunos eu não gosto muito de me expor. Reservome o direito de ter minha vida, como muitos professores heteros o fazem. Náo gostam de ficar falando muito de família, filhos, vida particular. Eu não sou muito de falar. Nem profissionalmente eu exponho minha vida particular. (Marina, agosto de 2007).

Semelhante à postura de Marina, Renato nos relatou que nunca se assumiu perante seus alunos e suas alunas mesmo que, por diversas vezes, tentassem de maneira indireta levá-lo a falar. Segundo ele, a identidade sexual do professor não faz parte do conteúdo do currículo escolar a ser transmitido.

Mas eles sabem da sua opção e é sempre aquela coisa assim, talvez por você ser mais velho: 'Você não é casado professor?' 'Não!' 'Por que você não casou ainda?' 'Eu ainda não me casei.' Aí, tem sempre aquela perguntinha: 'E professor, esse negócio de você não casar, hein?' Mas nunca fazem a pergunta diretamente: 'Professor, o senhor é homossexual? O senhor é gay?' Não, isso aí, nunca. [...] Na verdade, eles 
não querem me apontar, eles querem ouvir da minha boca. Apontar-me, seria, de certo modo, agredir aquela figura do professor. Às vezes, eles tentam, numa pergunta, outra, de alguma forma ou de outra, tirar isso da minha boca. (Renato, agosto de 2007).

Marina e Renato comungam a mesma opinião dos/as cinquenta e dois docentes que responderam o questionário de que um/a professor/a homossexual não deveria permitir que os/as alunos/as soubessem como ele/ela vive a sua sexualidade. Trinta docentes justificaram especificamente em suas respostas afirmando que a vida pessoal de professor/a náo deve ser discutida em sala de aula. A opiniáo de uma docente é semelhante à de Renato. Ela afirma que "a vida pessoal não deve ser discutida com alunos, a não ser que a vida íntima do professor faça parte do currículo".

$\mathrm{O}$ estudo evidenciou que o falar da vida pessoal de professores/as homossexuais na escola parece representar para parte dos sujeitos da pesquisa e, principalmente, para os/as docentes (heterossexuais e homossexuais) que responderam o questionário, o detalhamento das preferências e a forma como esses sujeitos atuam nas relaçóes sexuais, descartando a possibilidade de esta discussão representar um novo aprendizado sobre as diversas formas de manifestação da condição humana.

Nesse sentido, ressalto a argumentação de Rofes (2005) de que ao insistirmos que as questóes que se referem à sexualidade permaneçam na esfera privada, apagadas das discussóes da esfera pública, estamos contribuindo para um completo aparato de controle social, afirmando a repugnância da prática afetivo-sexual entre pessoas do mesmo gênero, mantendo em lugares seguros o patriarcado e o heterossexismo. Este fato ficou evidente quando os sujeitos disseram de sua percepção com relação aos/às alunos/as homossexuais na escola.

\section{Compartilhando silêncios: percepções e relações com alunos/as homossexuais na escola}

Sobre a questáo da homossexualidade de alunos/as os sujeitos relataram que nas relaçóes cotidianas da escola os alunos/as homossexuais, predominantemente do gênero masculino, são vítimas de grande número de preconceitos e discriminação por outros/as alunos/as, situação que foge ao controle e do campo de intervenção dos/as docentes. Marina foi enfática a esse respeito. 
Eu acho muito difícil. Os alunos hoje estão muito difíceis, porque os meninos, como se diz, pegam para Cristo, implicam mesmo. Por mais que você tenta colocar um limite, orientar os alunos para terem respeito com os colegas homossexuais, mas você vê, eles na rua, na porta da escola, no corredor. Você pode conseguir controlar dentro da sala de aula, ali, uma crítica, mas fora, você sabe que ela acontece e, às vezes, até dentro da sala com o professor. (Marina, agosto de 2007).

Perguntei aos sujeitos como eles/as percebiam os/as alunos/as homossexuais na escola e que tipo de relação estabeleciam com esses sujeitos. A postura do "ficar dentro armário", a omissão da homossexualidade de alunos/as, principalmente do gênero masculino, foi evidenciada por Fernando, Rogéria, Renato e João, estando essa postura diretamente relacionada ao medo de vivenciar o preconceito.

Os meninos continuam naquela postura do guarda roupa, uma coisa bem velada, mas a gente percebe e os colegas também percebem. Eles são vítimas, talvez, a gente não tem relato disso, mas eu acredito que na intimidade deles, o que não chega até nós, eles possam sofrer algum tipo de discriminação. Eu acredito que sim, pela postura que os meninos adotam com os professores, imagina entre eles, porque, com os meninos, isso é mais grave, eu acredito. (João, agosto de 2007).

Eu tenho alunos que eu noto que são gays, homossexuais, alguns ainda não se descobriram, outros já se descobriram, mas estáo caladinhos por causa do preconceito. (Fernando, junho de 2007).

Com relação à homossexualidade de alunas, Marina afirmou ser mais difícil identificá-las. Para ela, a aluna bissexual é quem mais expóe sua homossexualidade. João e Brenda comentaram que as alunas lésbicas são as que mais se aproximavam para conversarem sobre sua sexualidade, João avaliou a postura dessas alunas como mais madura e tranqüila comparada à postura dos alunos gays.

Para Fernando, Renato e Rogéria, as alunas lésbicas eram vítimas de menor discriminaçáo por parte de outros/as alunos/as e que isso se dá pelo fato de ao assumirem uma postura masculina, uma vez que essas meninas revidavam fisicamente às agressóes verbais realizadas pelos colegas.

Eu tenho uma aluna de $4^{a}$ série que fala abertamente:

'Não professor eu gosto mesmo é de futebol, não gosto 
de boneca, casinha e de carimbada. Eu gosto é de futebol, gosto de brincar com os meninos.' E os meninos falam para ela na sala: 'Você não está percebendo que você gosta só de coisas de homem?' 'Eu gosto! E daí? Eu gosto e pronto!' E é assim: 'Quem achar ruim eu bato!' E a conversa pára. (Renato, agosto de 2007).

Seria, então, o receio por parte de alunos de terem suas masculinidades comprometidas ao "apanharem de uma mulher" que possivelmente reduziria a incidência de agressóes verbais às alunas lésbicas, ou ainda, poderíamos pensar num apoderar-se da masculinidade como uma forma de recompensa por perpetuar a idéia de ser o gênero masculino digno de imitação. (LEK, 2005).

Sobre a forma de laços estabelecidos entre os sujeitos e os/as alunos/ as homossexuais, Fernando mantinha um distanciamento desses sujeitos, principalmente por receio de ser interpretado por colegas de trabalho como se estivesse assediando os alunos ${ }^{6}$.
[...] eu tenho um aluno que inclusive tem o meu nome.
É um aluno do primeiro ano do segundo grau e eu sei que ele é gay e ele também sabe que eu sou gay. Já nos encontramos nos lugares, mas nunca trocamos uma palavra: 'Você vai a tal lugar?' Eu procuro me distanciar dele para privá-lo de gracinhas. Já fazem gracinha comigo e já fazem com ele. Eu tenho medo de até estar conversando e ter certo grau de amizade e os colegas confundirem achando que eu estou me aproveitando da situação. (Fernando, junho de 2007).

Marina relatou-me que sua homossexualidade era percebida por alunos/ as homossexuais e que já vivenciou situaçóes nas quais foi assediada por alunas lésbicas. Sobre como percebia esses sujeitos nas relaçóes cotidianas da escola, Marina partilha da opiniáo de Fernando, identificando os alunos homossexuais com manifestaçóes mais evidentes de feminilidade como sendo aqueles que mais vivenciam o preconceito e a discriminação: "[...] depende muito do aluno, porque tem alunos que são debochados. Estes são alvo de mais críticas porque são muito debochados. Outros são mais discretos, não são muito criticados. Os mais discretos, mais na deles, não têm muitos problemas." (Marina, agosto de 2007).

6 A docente que respondeu o questionário da pesquisa, apontou essa questão ao comentar que: "Independente da vivência sexual, não devemos "escancarar" nossa intimidade, pois a diferença de maturidade pode acabar levando a interpretaçóes maliciosas e a falta de respeito à sexualidade de cada um, inclusive do professor sobre os alunos." 
Renato e João apresentaram percepçôes contrárias sobre essa questão. Para ambos, nem sempre os alunos gays com trejeitos femininos são os que mais sofrem discriminaçáo nas relaçóes escolares. Joáo enfatizou que na escola em que trabalhava os alunos com trejeitos femininos que se assumiram abertamente gays eram menos agredidos e conseguiram impor respeito por essa postura. Renato percebe este fato de maneira semelhante.

Eu tenho um aluno que ele não tem tanto trejeito, mas ele é aquele aluno tímido, sensível, de repente, é o pior dos casos. Eu acredito que o aluno com trejeitos, mas que se solta, discute em sua casa, na rua é aquilo e pronto, sofre menos do que aquele tímido. Este deve passar aperto em casa, com os colegas, na escola e fica retraído. Na quintafeira, por exemplo, eu presenciei um caso assim. $\mathrm{O}$ aluno deve ter $1,70 \mathrm{~m}$, sétima série, isso. Ele estava num canto assim, aí eu lhe disse: 'Olha, não fica triste não meu filho, tudo é fase na vida da gente. Vai chegar um dia em que você vai rir dessa tristeza que você está hoje.' E ele me disse: 'Ah, não sei professor, não sei se eu agüento isso não.' Nessa mesma hora, me deu vontade de abrir um trabalho, de repente, para esse aluno escrever alguma coisa, porque eu senti que ele estava a ponto de fazer uma besteira. Era o terceiro dia que eu o via naquele canto. Um aluno bonito, provavelmente, cantado mesmo, porque já é rapazinho. Eu senti que a dificuldade dele era essa, tanto era que no quinto horário ele abriu um sorriso para mim e falou: 'Obrigado, professor.' Eu não falei sobre o que era e ele também não me disse, mas, eu acredito que acertei o que ele passava naquela hora. (Renato, agosto de 2007).

Em determinadas ocasióes, Brenda e Rogéria tiveram que interceder em defesa de alunos homossexuais quando esses eram vítima de discriminação manifestada por outros alunos. Rogéria comentou que nessas ocasióes, sua identidade de gênero também era evidenciada pelos agressores.

Os colegas massacram, tanto que quando eles começam a massacrar, eles correm para trás de mim. Eu sirvo de escudo. Eu chamo a atenção daquele aluno que está massacrando e ele já vem com gozação: 'É, professor, eu sei por que você está defendendo ele. Nós sabemos muito bem porque que você o defende.' Então, tem isso: 'Ah, você gosta do fulano.' Às vezes, eu falo que eu gosto tanto do fulano, porque o fulano é inteligente, faz tudo, é disciplinado [...] 'Ah, você gosta dele porque ele é igual ao senhor'. (Rogéria, julho de 2007). 
Quando ocupou o cargo de coordenação de uma escola na qual trabalhou, Brenda foi por várias vezes designada para resolver problemas que envolviam alunos/as homossexuais. Dentre os episódios vividos, contou-nos de um aluno homossexual que tentou, na sala de aula, disputar território com ela. Resolveu a situaçáo chamando-o para uma conversa à parte, definindo as posiçóes de professora e de aluno.

\begin{abstract}
Ele tentava chamar a minha atenção na sala o tempo inteiro, mas, de uma forma negativa. Conversando, aprontando, não levando caderno, não fazendo os deveres, não trabalhando dentro de sala de aula em conjunto. E de repente, ele tentou fazer com que [...] Sabe quando você tenta criar no outro indivíduo uma antipatia? Ele tentou fazer isso. Eu o chamei num canto e falei: 'Você está jogando do lado errado, eu náo estou aqui para te julgar, nem para disputar espaço com você, principalmente porque a sua faixa de idade não encaixa com a minha. Eu não vou disputar território com você nunca e para você chegar onde eu estou, você terá que caminhar demais, então, espelhe-se nas minhas qualidades, nos meus defeitos náo'. (Brenda, dezembro de 2007).
\end{abstract}

Brenda, contudo, ressaltou a dificuldade em orientar alunos gays que a procuraram quando se viam em conflito com a descoberta de sua identidade sexual.

Eu já tive outros alunos, por exemplo, que tinham problemas de sexualidade e que me chamavam para conversar. Pedindo socorro. Meninos. Eu não sabia o que fazer, porque eu pensava assim: 'Meu Deus se eu falo vai, ele se estrepa e eu o mandei ir. Se eu falo não vai, ele também vai se estrepar.' Então, o que na maioria das vezes eu falo é: 'Meu filho, consulte um psicólogo, vai conversar com um especialista no assunto, mas, eu acho que você deveria começar a conversar com seus pais.' Porque eu não acho justo você esconder isso de um pai e de uma mãe. (Brenda, dezembro de 2007).

Rofes (2005) descreveu que estaríamos equivocados ao acreditar que a simples presença de professores gays assumidos na escola representaria uma atitude contra-hegemônica. Para o autor, se esses sujeitos assumem, nas suas práticas educacionais, os princípios da masculinidade tradicional, poucas alteraçóes ocorrerão no nocivo sistema sexo/gênero vigente nas sociedades ocidentais. Com isso, uma das preocupaçóes de Rofes (2005) é de que quando professores gays restringem suas atuaçóes pedagógicas a esses limites estreitos, oferecem não somente aos alunos gays, mas a todos/as os/as demais, 
exemplos de uma identidade homossexual pouco relevante para suas vidas e que colaboram restritamente para que estes/as consigam enfrentar as difíceis e necessárias escolhas para a construçáo de suas próprias identidades sexuais e de gênero.

O distanciamento dos alunos gays relatado por Fernando, o desejo não realizado de propor discussóes sobre a homossexualidade por Renato perante o sofrimento de seu aluno e o receio de Brenda ao aconselhar seus alunos gays expressam as reflexóes do autor. Em outros momentos, entretanto, na fala desses sujeitos essa questáo aparece de maneira diferente, uma vez que o ser assumidamente homossexual se mescla com um cuidado tomado por parte dos sujeitos ao tentarem fazer com que os/as alunos/as não identifiquem de maneira clara as marcas dessa identidade.

Às vezes chega até ser meio contraditório. Eu fico na minha. Não vejo muita diferença entre os outros professores e eu. Acho que eu tenho a mesma postura. Tem os trejeitos que não tem como eu mudar e também acho que nem tenho que mudar por causa disso. Mas eu mantenho aquela certa distância, assim, não dou muita bandeira, não sou muito aberto ao assunto. Porém, em algumas turmas eu busco dar um esclarecimento voltado mais para a questão da vivência com as outras pessoas, não comigo. Talvez até comigo mesmo, mas eu tento mostrar que eles devem conviver com as diferenças das pessoas e respeitá-las. De certa forma, até para que me respeitem também, me vendo com outros olhos. Mas eu tento deixar mais escondido, eu tento deixar que eles descubram que eu sou gay e me respeitem pelo que sou. Eu não tenho nenhuma atitude que faria com que me desrespeitassem, tipo, desmunhecando, falando, encarando aluno, porque existem casos de professor que encarara o aluno. (Fernando, junho de 2007).

[...] eu sinto que eles sentem uma diferença, uma coisa assim, inexplicável, mas eu já acredito que é a questão da postura, a questão de eu não ter alguns tiques, algum ataque. A gente percebe que, às vezes, os outros têm uns ataques, o que chama a atenção do aluno. Como você é claro e pronto o aluno fica em dúvida: 'Será que é?' 'Será que não é?' Acham tâo estranho que, na dúvida, o deixam quieto. (Renato, agosto de 2007).

Os relatos deste bloco evidenciam a forma como os espaços escolares são delimitados e envolvidos por dispositivos e práticas sutis que penetram lugares possíveis de serem ocupados por cada pessoa, evidenciando, também, o estabelecimento das relaçóes das poder que constituem as hierarquias 
socioculturais fragilizando, em vários momentos, a possibilidade dos sujeitos de resistir a elas (LOURO, 1997, 2004).

Com isso, a homossexualidade e a travestilidade de docentes parece assumir uma falsa visibilidade ou uma visibilidade comedida e limitada. Portanto, ao contrário de proporcionar a resistência e novos aprendizados com relação às determinações hegemonicamente construídas, alimenta sua manutenção, expressada ou pela tentativa de omissão de suas vivências pessoais ou pelo afastamento de alunos/as que compartilham das mesmas identidades sexuais e de gênero.

Torna-se transparente o temor dos sujeitos de serem responsabilizados ou acusados, principalmente pela família, quando seus/as alunos/as homossexuais assumam suas identidades sexuais, constatação feita também no estudo de Márcio Caetano (2006) quando investigou a resistência de não se assumir uma identidade homossexual na escola, reduzindo as possiblidades de tornar o espaço escolar tmbém um local de verbalizaçáo do desejo e de demarcaçáo política por meio da diferença. Esse mesmo autor também evidenciou o medo como a principal ação motivadora da invisibilidade, sobretudo por parte de docentes, uma vez que "o fato ganha ainda mais força se levarmos em consideração que os/as professores/as acreditam que os pais e/ou responsáveis dos/as alunos/as são homofóbicos e que, portanto, não desejariam um filho/a homossexual." (CAETANO, 2006, p. 102).

\section{Considerações finais}

Dentre os elementos abordados neste texto, correlacionados à pesquisa no geral, um dos principais aspectos evidenciados foi que o/a professor/a gay, travesti e lésbica ao exercer a profissão docente não se desvincula das marcas da sexualidade e do gênero inscritas em seu corpo, mesmo que náo as anuncie, deixando flagrar notadamente a diferença, provocando impactos tanto em alunos/as, docentes e/ou outros sujeitos envolvidos no processo educativo, confirmando a estreita relação da escola com os princípios religiosos e morais que desde sua criação permanecem determinando as diretrizes da profissão docente e atribuindo aos profissionais dessa área (sob a concepção de sujeito estável, fixo e hegemônico) o legado de "modelo a ser seguido" e "exemplo" (LOURO, 1997; NÓVOA, 1991).

As formas não convencionais de vivência das sexualidades e de construção do gênero se chocam com esses princípios, principalmente porque a homossexualidade e a travestilidade são possibilidades de manifestação da 
condição humana que causam estranhamento social, sobretudo, por contestar os princípios definidores e estruturantes das sociedades ocidentais, dentre os princípios mais importantes, a ênfase no masculino e na heterossexualidade. Com isso, a pesquisa evidenciou a homossexualidade masculina como o fator de maior impacto nas relaçóes cotidianas da escola e, por mais que nosso enfoque fosse o docente, alunos homossexuais foram também evidenciados como alvo de discriminação e de preconceito nessas relaçóes.

Apesar dos sujeitos adotarem em suas práticas pedagógicas os princípios necessários à profissão docente, em alguns momentos de suas histórias de vida profissional o fato de serem docentes não amenizou a exposição à agressão, direta ou indireta, verbal ou não-verbal, manifestadas por alunos/as e/ou por outros sujeitos que compóem o cotidiano escolar, dadas suas identidades sexuais e de gênero, evidenciando que a escola é também um dos espaços sociais no qual a homofobia é ensinada e aprendida.

\section{Referências}

ABRAMOVAY, Miriam; CASTRO, Mary Garcia; SILVA, Lorena Bernardes. Juventude e sexualidade. Brasília: UNESCO, 2004. Disponível em: www. unesco.org.br/publicacoes/livros/juvsexualidade/mostra_documento. Acesso em: 02 de novembro 2007.

BRASIL. Ministério da Saúde. Secretaria de Assistência à Saúde. Programa Nacional de Doenças Sexualmente Transmissíveis/AIDS. A travesti e o educador: respeito também se aprende na escola. Brasília, 2001. (folder da campanha Travesti e respeito: já está na hora dos dois serem vistos juntos. Em casa. $\mathrm{Na}$ boate. $\mathrm{Na}$ escola. No trabalho. $\mathrm{Na}$ vida.).

BRASIL. Ministério da Saúde. Secretaria de Assistência à Saúde. Programa Nacional de Doenças Sexualmente Transmissíveis/AIDS. Manual do Multiplicador: homossexual. Brasília: Ministério da Saúde, 1996.

BRASIL. Ministério da Saúde/Conselho Nacional de Combate à Discriminação. Brasil sem homofobia: Programa de Combate à violência e à Discriminação contra GLTB e de Promoção da Cidadania Homossexual. 2. ed. Brasília: Câmara dos Deputados, Coordenação de Publicaçôes, 2004.

BRASIL. Orientação sexual. In: Brasil. Ministério da Educação e do Desporto. Secretaria de Educação Fundamental. Parâmetros Curriculares Nacionais: pluralidade nacional e orientação sexual. Rio de Janeiro: DP\&A, 2000. v. 10. 
BUTLER, Judith P. Problemas de gênero: feminismo e subversão de identidade. Tradução de Renato Aguiar. Rio de Janeiro: Civilização Brasileira, 2003.

CAETANO, Márcio. Os gestos do silêncio para esconder as diferenças. In: SEFFNER, Fernando et al. Corpo, gênero e sexualidade: problematizando práticas educativas e culturais. Rio Grande: FURGS, 2006.

CENTRO PARANAENSE DE CIDADANIA - CEPAC. Ministério da educação. Educando para a diversidade: como discutir homossexualidade na escola? Brasília: Ciranda, 2005. 62 p. (guia para educadores/as).

FRY, Peter; MACRAE, Edward. O que é homossexualidade. São Paulo: Abril Cultural/Brasiliense, 1985.

GREGERSEN, Edgar. Práticas sexuais: a história da sexualidade humana. Tradução de Antônio Alberto de Toledo Serra. São Paulo: Roca, 1983.

HILTON, Bruce. A homofobia tem cura? O papel das igrejas na questáo homoerótica. Tradução de Sieni Maria Campos. São Paulo: Ediouro, 1992.

LEK, Glorianne M. Uniformes escolares, pantalones anchos, muñecas Barbie y trajes de ejecutivo en los consejos escolares. In: TALBURT, Susan.; STEINBERG, Shirley, R. (org.). Pensando queer: sexualidad, cultura y educación. Tradução de Begoña Jiménez Aspizua. Barcelona: Graó, 2005.

LOURO. Guacira Lopes. Gênero, sexualidade e educação: uma perspectiva pós-estruturalista. 5. ed. Petrópolis, RJ: Vozes, 1997.

LOURO. Guacira Lopes. Pedagogias da sexualidade. In: LOURO. Guacira Lopes. (org.). O corpo educado: pedagogias da sexualidade. Belo Horizonte: Autêntica, 1999.

LOURO. Guacira Lopes. Um corpo estranho: ensaios sobre sexualidade e teoria queer. Belo Horizonte: América, 2004.

NÓVOA, Antônio. O passado e o presente dos professores. In: NÓVOA, Antônio. (org.). Profissáo professor. Tradução de Irene Lima Mendes, Regina Correa e Luisa Santos Gil. Porto Codex: Porto, 1991.

NUNES, César; SILVA, Edna. A educação sexual da criança: subsídios teóricos e propostas práticas para uma abordagem da sexualidade para além da transversalidade. Campinas: Autores Associados, 2000. 
PAREDES, Eugênia C.; OLIVERIA, Rita A.; COUTINHO, Marta Maria Telles. Sexualidade: o que têm a dizer alunos e professores da rede pública de ensino cuiabana. Cuiabá: EdUFMT/FAPEMAT, 2006. v. 3.

ROFES, Erick. La transgresión y el cuerpo ubicado: el género, el sexo y los profesores varones gays. In: TALBURT, Suzan.; STEINBERG, Shirley R. (org.). Pensando queer: sexualidad, cultura y educación. Tradução de Begoña Jiménez Aspizua. Barcelona: Graó, 2005.

SILVA, Tomaz Tadeu. Documentos de identidade: uma introduçáo às teorias do currículo. 2. ed. Belo Horizonte: Autêntica, 2007.

SWAIN, Tânia Navarro. Lesbianismo, cartografia de uma interrogação. In: RIBEIRO, Paula Regina et al. (org.). Corpo, gênero e sexualidade: discutindo práticas educativas. Rio Grande: FURG, 2007.

TREVISAN, João Silvério. Devassos no paraíso: a homossexualidade no Brasil da colônia à atualidade. 6. ed. rev. e aum. Rio de Janeiro: Record, 2004.

WEEKS, Jeffrey. O corpo e a sexualidade. In: LOURO, Guacira Lopes. (org.). O corpo educado: pedagogias da sexualidade. Belo Horizonte: Autêntica, 1999. 


\section{MULHERES, LUTAS E REPRESENTAÇÕES: CAOS ${ }^{1}$, CRONOS² E INVENÇÃO DA (DES) IGUALDADE}

Qelli Viviane Dias Rocha

\section{A questão da cidadania}

É.

Agentequerviverplenodireito;Agentequervivertodorespeito A gente quer viver uma nação; A gente quer é ser um cidadão A gente quer viver uma nação; A gente quer é ser um cidadão A gente quer viver uma nação [...]. (Gonzaguinha) ${ }^{3}$

Iniciaremos nossa reflexão, partindo das orientaçóes de Barbalet (1989) e suscitando o debate sobre os limites da cidadania. De acordo com esse autor, a cidadania é em si é um sofisma, se constituindo por uma natureza formal que implica um sistema político igualitário, cuja base formativa e de sustentação é uma "sociedade divida por contradiçóes de desigualdades".

Desigualdades que segundo Marshall (1967) podem ser diminuídas, mas jamais superadas. Para ele, um raio amplo de "desigualdade quantitativa ou econômica constituem partes do processo ćivilizatório’ (grifo nosso)”.

[...] postula que há uma espécie de igualdade humana básica associada com o conceito de participação integral na comunidade - ou, como eu diria, de cidadania - o qual não e inconsistente com as desigualdades que diferenciam os vários níveis econômicos na sociedade. Em outras palavras, a desigualdade do sistema de classes sociais pode ser aceitável desde que a igualdade de cidadania seja reconhecida. (MARSHALL, 1967, p. 62).

1 De acordo com Hesíodo, na Teogonia, Chaos (Caos) é a designação de um o tempo remoto, um espaço vazio entreaberto (com o sentido de 'abismo profundo', não o de 'desordem'). $\mathrm{O}$ feminino que por meio da relação com Eros, estabelece a relaçấo consciente entre a vontade e o desejo.

2 Cronos é a Deudade monolítica que estabelece o domínio e/ ou soberania masculina, afim de "organizar/ disciplinar a Caos. In: file://C:/Users/qelli/Downloads/2392-8729-1-PB.pdf. Brasete. M.F. Acesso em: 10 de março 2018.

3 GONZAGUINHA. É. LP Coraçóes Marginais. Moleque/WEA, 1988. 
Esta compreensão de cidadania, ao náo reconhecer o status/privilegio ${ }^{4}$ como parte intrínseca do acesso à direitos, estabelece diferenciaçôes entre eles. Segundo o autor, a cidadania moderna pode ser apreendida em três dimensóes; civil, político e social; o 'elemento' civil, é composto pelo direito individual; 'elemento' político como o direito de participar do exercício político como membro de um organismo investido de autoridade e o 'elemento' social que determina participação efetiva social e politicamente ampliada de participaçáo nos demais 'elementos' constitutivos da cidadania. Essas diferenciaçôes têm por finalidade a separação entre Sociedade civil e Estado, também, separação da vida pública e privada, objetivando de modo geral, a náo interferência do Estado na vida social. Depreendemos disso que, nesta concepçáo a "cidadania civilizatória" é um "modo de viver que brota de dentro de cada indivíduo e não como algo imposto fora dele." (MARSHALL, 1967, p. 62).

De acordo com Barbalet (1989; p. 56), a cidadania moderna, náo deve e/ ou pode ser confundida com outras formas de cidadania, pois para o autor, o processo de instituiçáo da cidadania moderna inscreve a eliminaçáo da monarquia, do campesinato servil em detrimento da usurpaçáo rural mais elevada, da emergência do processo industrial. De modo geral, institui a competiçáo intraclasses, entre rural e urbano, que acaba por se manifestar no alargamento ao direito ao voto e nas legislaçôes sociais que implementam as leis de proteção operárias e, principalmente, no próprio surgimento do movimento da classe trabalhadora.

Marshall (1967) defende que a cidadania, nas modalidades política e social, constitui bases de participação efetiva que dirimem as desigualdades civis ${ }^{5}$. Todavia, cabem aos sujeitos (trabalhadores) a partir da igualdade básica (acesso à educação formal), direito por ele defendido como incontestável, enriquecer em substância e concretização os direitos formais ${ }^{6}$.

Até mesmo esse direito de "civilidade", entretanto, não era [é] acessível e/ou acessado por todos, dado o processo de desenvolvimento das forças produtivas.

4 Compreendida por Barbalet, bem como, para outros teóricos que analisam a categoria cidadania, esta pode ser apreendida e analisada em suas diferentes formas, entretanto costumase partir da perspectiva clássica (grego-aristotélica), como privilegio - status

5 Cabe salientar que nesta perspectiva, os direitos civis são abstratos, uma vez que abrangem todos os homens e mulheres, embora objetivamente apenas os burgueses detinham condiçóes jurídicas que lhes impulsionava à luta pelos direitos sociais e políticos.

6 Porém cabe nos estranhar, seria possível aumentar o nível de participação política e social sem efetivamente alargarmos e/ou mudar efetivamente as bases de participação civil? Não é por meio da participação civil que se institui e/ou reconhece os direitos de propriedade? Que se institui o próprio Estado e suas formas de organização da vida social? 
Os trabalhadores livres assalariados, destituídos dos meios de produção, não detinham/detêm condiçóes objetivas para se civilizarem.

\begin{abstract}
$\mathrm{Na}$ história da acumulação primitiva, o que faz época são todos os revolucionamentos que servem de alavanca à classe capitalista em formaçáo, mas, acima de tudo, os momentos em que grandes massas humanas são despojadas súbita e violentamente de seus meios de subsistência e lançadas no mercado de trabalho como proletários absolutamente livres. (MARX, 1984, p. 964).
\end{abstract}

As explicações para a não participação na vida social e política advinham, nessa direção, da falta de capacidade pessoal. Deste modo, a transição da cidadania grego-aristotélica, para a cidadania moderna, inscreve o status como um "conjunto de direitos", advindos da "natureza social".

Em termos mais gerais, os direitos são significativos porque atribuem às pessoas capacidades especiais em virtude de um status legal ou convencional. Isto é, as pessoas podem ter certas capacidades ou oportunidades para açóes particulares - certos poderes - em consequência de seu status. (BARBALET, 1989, p. 32).

Dada a complexidade do processo de sociabilidade naquele contexto, o autor vislumbrou a "dialética" no processo constitutivo da cidadania em sua manifestação moderna. Entretanto esta perspectiva, escamoteia todo o conflito e contradição da separação entre direitos civis, políticos e sociais, pois, se o primeiro, inicialmente corrobora para a manutenção da propriedade privada, as contradiçóes existentes entre as classes, que naquele momento histórico, forjam as bases para que os trabalhadores se constituam como categoria social e política, exigindo respostas concretas e materiais para diminuição entre as desigualdades próprias e particulares do modo de produção capitalista, o que fazia surgir demandas por participação política e social.

Queremos com isso apontar que a separação entre os direitos de cidadania apreendida por Marshall como naturais e evolutivos, antes, à nossa perspectiva só são assim determinados porque buscam responder de forma restrita e pontual as demandas por igualdade erigidas pela classe trabalhadora.

Destarte, a defesa marshalliana ao partir da apreensão da cidadania nas suas manifestaçóes particulares, ou seja, cidadania; civil, político e social, pressupunha uma relação de dependência no construir da cidadania para com o Estado. Para Marshall, se a estrutura societária moderna se forja sob a base da desigualdade, cabe o Estado enquanto mediador desse sistema desigual 
estabelecer formas de acesso ao status coma finalidade de diminuir ou de administrar as condiçóes de acesso à oportunidade de igualdade.

[...] os direitos políticos da cidadania, ao contrário dos direitos civis, estavam repletos de ameaça potencial ao sistema capitalista, embora aqueles que estavam estendendo, de modo cauteloso, tais direitos às classes menos favorecidas provavelmente náo tivessem plena consciência da magnitude de tal ameaça. (MARSHALL, 1967, p. 85).

Tomando como referência Therborn (1977, p. 34), Barbalet (1989, p. 58) evidenciou que, o conflito de classe institui e estabelece as contradiçóes e antagonismo para a implementação da cidadania moderna, isto porque, ao mesmo tempo que o movimento da classe trabalhadora surge, três restriçóes à cidadania democrática passam a ser evidenciadas: I) mesmo em fases de apogeu às conquistas da classe trabalhadora trazem em si manifestaçóes de concessão da classe dominante; II) a classe trabalhadora em si não detém meios materiais de forma direta e independente para revolucionar e III) por deter os meios de produção e reproduçáo social a classe dominante acaba por "determinar" as condições objetivas de manutenção e ou retirada de direitos, mesmo em períodos "prolongados de concessão e conciliação de classe". Como podemos observar, o Estado comparece como intermediador das relaçóes de cidadania.

Malgrado, para Barbalet (1989) a cidadania traz em si, questóes estruturais que condiciona, quando não, impóe limites. A questão da cidadania na modernidade seria assim um sofisma, pois as bases que forma o modo de produção capitalista é o que gera a desigualdade, como parte constitutiva e constituinte deste modo de produção, tal desigualdade guarda relação direta com a questão econômica; se a questão da cidadania aparta-se da questão econômica; como pode, então buscar meios ou formas senão, através da questão econômica ( estrutural) para superar as desigualdades gestadas por esta?

Como pensar o Estado como ente superior na regulação da vida social e política se os interesses defendidos guardam relação com os direitos de propriedade?

Considerando que fora o próprio processo de desenvolvimento e complexificação do modo de produçáo capitalista que tratou de separar o Homem dos meios de produção e, uma vez feito isto, o trabalhador despossuído de tudo teve que vender sua força de trabalho e ainda assim ver aumentar sua pobreza, na mesma proporção na qual contribuía para o aumento da riqueza 
daqueles agora possuidores dos meios de produção. Viu-se então, conforme Marx (1984; p. 960) a "origem do pecado original". Pecado este que na realidade concreta se manifestou no surgimento de um modo particular de pauperismo, já que "a relação capitalista pressupóe a separação entre os trabalhadores e a propriedade das condiçóes da realização do trabalho. Tão logo a produçáo capitalista esteja de pé, ela não apenas conserva essa separaçáo, mas a reproduz em escala cada vez maior". (MARX, 1984, p. 962).

Esse processo, não é considerado por Marshall na elaboração sobre a teoria da cidadania, ao separa os direitos sociais em categorias distintas, os torna estruturais, estanques e a nossa compreensáo, são a-históricos, mesmo quando recorre à Pollanyi, Marshall (1969, p. 71) separa a Poor Law em dois momentos não contraditórios, mas conflituosos entre si. Para ele, na primeira fase da poor law vê-se a defesa dos direitos sociais de cidadania, mais agressivo, pois parte da intervenção material (econômica) na vida dos trabalhadores, porém na segunda fase da poor law que corresponde ao período de 1834, o direito civil é escamoteado ao direito social.

A Poor Law tratava as reivindicaçôes dos pobres não como
uma parte integrante-de" seus direitos de cidadão, mas como
uma alternativa deles_como reivindicaçōes -que poderiam
ser_atendidas somente se deixassem inteiramente de ser
cidadãos. Pois, os indigentes — abriam mão, na prática, -, do
direito civil da liberdade pessoal devido ao internamento na
casa e eram obrigados por lei a abrir mão de quaisquer direitos
políticos que possuíssem. Essa incapacidade permaneceu em
existência até 1918. (MARSHALL, 1967, p. 72 ).

A contradição do sistema emergente, fazia nascer ao mesmo tempo uma nova classe social em processo de autorganização (classe trabalhadora) e os direitos sociais, como antítese da cidadania. para Marshall (1967), a cidadania estabelecida a partir da bivalência direito e deve exigia intervenção do Estado como garantidor de mínimos sociais.

Surge a partir desta perspectiva o Estado Social, que segundo Barbalet (1989, p. 104), embora náo desnaturalize a responsabilidade do sujeito por seu provimento pessoal, não compreende um perigo a provisão de cuidados com a saúde e educaçáo por parte do Estado. Boschetti (2015, p. 17), diz fazer uso na atualidade sobre o termo, por sê-lo mais do que uma conceituação, mas um atributo à um tipo de Estado que designa ou caracteriza para uma "feição" social por meio de direitos implementados pelas políticas sociais, entretanto não retira deste sua natureza capitalista e nem faz deste uma instância neutra de produção de bem estar. 
Cabe salientar que no âmbito da discussão do Estado Social é preciso decompor como as categorias cidadania, política social e direito social se manifestam, como dito por Barbalet (1989).

A ideia de que os direitos sociais podem se constituir um elemento de cidadania, não só é fundamental nos estudos de Marshall, mas também se tornou parte das interpretaçóes mais comuns mais correntes no século XX dos direitos e da cidadania. Todavia, a afirmação de que os direitos sociais podem ser direitos da cidadania justifica um exame crítico por ao menos três razóes. Primeiro, os direitos de cidadania são direitos de participaçáo numa comunidade nacional comum. Os direitos sociais podem ser precisos para a prática da cidadania na medida em que tornam possível essa participaçáo. O que é o mesmo que dizer que, como meio de facilitar a cidadania, não se podem dizer que eles a constituem. Segundo os direitos de cidadania são necessariamente universais. Os direitos sociais por outro lado, são significativos apenas quando são substantivos; e os direitos substantivos nunca podem ser universais. Finalmente os direitos sociais são sempre condicionados à uma infraestrutura administrativa e profissional e em última análise à uma base fiscal; assim, ficarão mais bem definidos não como direitos, mas como oportunidades condicionadas. (BARBALET, 1989, p. 107).

Barbalet (1989) evidenciou como nos processos de complexificação do modo de produção a sociabilidade também foi se complexificando. Isto é, se por um lado nem todos podem ser cidadãos, aqueles que são destituídos dessa condição, se organiza e reivindica melhores condiçóes de vida e trabalho, tais reivindicaçóes passam a ser respondidas pelo acesso não à cidadania, mas aos direitos sociais, estes tendem a ser materializados por meio de políticas sociais, as quais nunca tenderão a responder universalmente os direitos sociais reivindicado. Ademais, a implementação destes direitos sociais via política social, tenderá a ter uma base fiscal, originaria "dos fundos" dos próprios trabalhadores.

Ao tomarmos como referência Boschetti (2015, p. 17), essa forma de organizaçáo e intervençáo do Estado é particular e fruto da crise de 1929, donde a intervenção do Estado "passou a ser crucial na definição de normas e regras e na garantia de fundo público necessários ao surgimento e desenvolvimento de amplas políticas sociais".

Para a autora, é um marco civilizatório que não altera o modo de produção capitalista em sua estrutura, mas altera os padróes de desigualdade entre as 
classes sociais. Agem, pois, como mediaçóes nos processos de luta de classe, tanto fortalecendo a classe trabalhadora, quanto restringindo o avanço da classe hegemônica.

Que emancipação das classes trabalhadoras tem que ser conquistadas pelas próprias classes trabalhadoras; Que a luta pela emancipação das classes trabalhadoras significa náo a luta por privilégios e monopólios, mas por iguais direitos e deveres e pela abolição do domínio de classes; Que a sujeição econômica do homem que trabalha para o monopolizador dos meios de trabalho, isto é, das fontes de visa repousa no amago da servidáo em todas as suas forma, de toda miséria social, degradação mental e degradação mental e de dependência política; [...] Que todas emancipação econômica das classes trabalhadoras é, portanto, o grande fim ao qual todo o movimento politico deve estar subordinado como meio. ( MARX, 2012, p.79).

Segundo Barbalet (1989), embora não se possa dizer de direitos sociais substanciais, a classe trabalhadora por meio do acesso ao direito político, fez alargar os direitos de cidadania. Estes só foram acessados por meio das forças de pressóes populares e pelas reformas orientadas para contenção destas forças. Assim, como nos escritos de Marx (2012), e nas afirmaçóes de Bischetti (2015), não compreendemos essa relação como binaria, mas dialética.

\section{Igualdade formal - o engodo!}

Se se acredita que a inserção da mulher no mercado formal de trabalho, o direito ao sufrágio universal e uma série de conquistas materializadas ao longo do século XX e início do século XXI seriam suficientes para que, por meio da igualdade jurídica, as mulheres efetivamente passassem a ser reconhecidas e tivessem acesso ao direito substancial, caiu-se num grande engodo. A implantação do modo de produçáo capitalista exige a igualdade de "status jurídico entre os Homens". (SAFFIOTI 2013, p.107). Entretanto, essa liberdade formal encontra sua contrapartida na divisão da sociedade em classes sociais e, consequentemente, na dominação de uma por outra.

Para Cisne (2014, p. 76), mesmo com a inserção da mulher no mercado formal de trabalho, estas continuam a ser estereotipadas, subordinadas e subjugadas, visto ocuparem postos de trabalho que ratificam a hierarquia e a dominação masculina, uma vez que, nestes postos de atuação, perpetuam características laborativas inatas e/ou "naturais". Ao tomar como referência os estudos de Souza Lobo (1991), presenciamos a "feminizaçáo do trabalho". 
No bojo desta sociedade, as mulheres permaneceram nas mais precárias condiçóes de trabalho, tanto no trabalho doméstico não remunerado, quanto no assalariado. Embora seja fundamental na garantia da produção e reprodução da vida social, o trabalho da mulher não é considerado e valorizado como trabalho que constrói a história. É tido como uma mera vocação vinculada às qualidades ou mesmo obrigaçóes supostamente naturais da mulher. (CISNE, 2014, p. 77).

Este processo de feminização do trabalho guarda relação direta com os processos de desenvolvimento das forças produtivas e, sua complexificação, com a órbita da sociabilidade capitalista. De acordo com Antunes e Alves (2004, p.335), as transformaçóes no modo de produção refletiram em transformaçóes na classe trabalhadora, "[...] esta já não é idêntica àquela existente em meados do século passado, ela também não está em vias de desaparição, nem ontologicamente perdeu seu sentido estruturante” .

Uma multiformidade assegurou o incremento da participação feminina na produção da força de trabalho que, de acordo com Antunes e Alves (2004) vem aumentado em torno de $40 \%$ em todo mundo e se caracteriza pela precarização e desregulamentação. Mas se por um lado podemos verificar a inserção significativa da força de trabalho feminina, por outro, este trabalho não é reconhecido, a remuneração é inferior à do homem e os direitos sociais e trabalhistas são também desiguais. Para esses autores “[...] a classe trabalhadora hoje compreende a totalidade dos assalariados, homens e mulheres que vivem da venda da sua força de trabalho - a classe que-vive-do-trabalho, conforme nossa denominaçáo" (Antunes, 1995 e 1999) - "e que são despossuídos dos meios de produção. Mas ela vem presenciando um processo multiforme [...]."

Nesse sentido, faz-se necessário pontuar que a luta das mulheres por igualdade formal, via manutenção do sistema capitalista, pouco tem avançado.

A 'luta por reconhecimento' está rapidamente se tornando a forma paradigmática de conflito político no final do século XX. Demandas por "reconhecimento da diferença" dão combustível às lutas de grupos mobilizados sob as bandeiras da nacionalidade, etnicidade, 'raça', gênero e sexualidade. (FRASER, 2006, p. 231).

Isto em si não se configura como problema. Contudo, as formas como se objetiva o acesso à direitos e bens e serviços com fins em si mesmos é que se configuram como grandes entraves à unidade no processo das lutas antimachistas- sexistas - racistas e anti-capitalistas. 
Como vimos, é próprio do sistema capitalista a separação e dicotomização público-privado, bem como os processos que constroem, instituem, naturalizam ou desnaturalizam, fortalecem ou enfraquecem a construçáo de identidades, pois o capitalismo não é cego aos sujeitos sociais e políticos constitutivos da classe trabalhadora.

Assim como a construção das relaçóes de gênero que, na maioria das vezes parte da construção cultural binarista que polariza homens e mulheres, donde a cultura suplanta a exploração como fundante da injustiça sociais, a redistribuição tem comparecido como solução política socioeconômica nos processos de reconhecimento cultural. (FRASER, 2006, p. 232).

Cabe salientar que a questão das identidades, na apreensão da teoria crítica, se tornou, por isso, um grande problema. À rigor, um problema insolúvel nestas circunstâncias. Já que aquilo que somos enquanto pessoas, nossas necessidades e possibilidades enquanto seres humanos, não encontram, nas relaçóes que mantemos com o gênero social e humano, um canal adequado para sua manifestação e desenvolvimento. Assim, não podemos, senão, manter uma relação de alienação e distanciamento para com a vida coletiva e social.

Para Silva (2000), inicialmente parece ser fácil definir identidade, uma vez que se torna o que se é: "sou mulher", "sou negra", "sou lésbica”. Para o autor, a identidade assim concebida se caracteriza por uma positividade, uma característica independente, um fato autônomo. Seguindo o mesmo raciocínio, para Silva (2000) a diferença é concebida como entidade independente, passando a ser o que náo sou, ou seja, passa a ser o que o Outro é: "ela é branca", "ela é heterossexual", "ela é mulher". Assim como na identidade, a diferença é concebida como algo que remete a si própria. "A diferença, tal como a identidade, simplesmente existe." Destarte, Tomaz Tadeu Silva (2000) apontou que identidade e diferença estão em uma relação estreita de dependência. A forma como expressa-se a identidade tende a esconder esta relação. (SILVA, 2000, p. 74).

Assim, quando se diz "sou mulher", faz-se referência a uma identidade que se esgota em si mesma. Entretanto, o autor chama atençáo para o fato de que só é necessária esta afirmação porque existem outros seres humanos (homens) que não são mulheres: “[...] em um mundo imaginário totalmente homogênio, no qual todas as pessoas partilhassem a mesma identidade, as afirmaçôes de identidade não fariam sentido.” (SILVA, 2000, p. 74).

Podemos confirmar então que que identidade e diferença partilham uma importante característica, resultado de atos de criação social e que, portanto, não são "elementos" da natureza. Identidade e diferença têm que ser ativamente produzidas. 
Esta produção identitária, conforme D’Atri (2008, p. 134), parte de uma perspectiva liberal que nos conduz ao equívoco de interpretar a sociedade como resultado de um somatório de indivíduos com múltiplas características identitárias que, ao mesmo tempo, nega a influência da totalidade do sistema capitalista. Assim, tomando como referência Terry Eagleton, D’Atri (2008, p. 134) afirma que "ninguém tem uma determinada pigmentação da pele porque outros tenham outra, ninguém tem um sexo porque há outros que possuem um diferente."

As identidades não são, portanto, criaturas do mundo natural ou transcendental, mas do mundo real e concreto e, neste sentido, fabricadas no contexto de relaçôes econômicas e sociais. É esta "fabricação" de identidades não só diferentes, mas dicotomizadas e bipolares, que estabelece as relaçóes entre homens e mulheres.

A delimitação de espaços, formas de ser, agir e estar no mundo de modo bipolar demonstra que a construção da identidade, a partir da diferença, é uma relação social que está sujeita a vetores de força e de poder. As identidades sociais tanto dos homens, quanto das mulheres, não são simplesmente definidas, são construídas por meio de uma imposição hierárquica. Esta imposição não se dá de modo "harmonioso", ao contrário, se dá por meio de disputas conflituosas.

Entretanto, esse polo diferença-identidade, sob a perspectiva que aqui se inscreve, não se constitui enquanto uma formulação excludente-includente, pois como já afirmado, a questão da construção das identidades só é possível de se desenvolver dentro de um "espectro" de unicidade.

Para expor em termos ontológicos, as categorias específicas do Ser Social, o seu desenvolvimento a partir das formas de ser precedentes, sua articulação com estas, sua fundamentação nelas, sua distinção em relação a elas, é preciso começar pela análise do trabalho. É claro que não se deve esquecer que, qualquer grau do ser, no seu conjunto e nos seus detalhes, tem um caráter de complexo, isto é, que as suas categorias, até mesmo as mais centrais e determinantes, só podem ser compreendidas adequadamente no interior e a partir da constituiçáo complexa do nível de ser de que se trata. E é suficiente um olhar muito superficial ao ser social para perceber a inextricável imbricação em que se encontram suas categorias decisivas como o trabalho, a linguagem, a cooperação e a divisáo do trabalho e para perceber que aí surgem novas relaçóes da consciência com a realidade e, em decorrência, consigo mesma, etc. (LUKÁCS, 2010a apud Rocha, 2012, p. 19). 
Como no processo de desenvolvimento da sociedade capitalista, os complexos sociais, como a fala, educação e leis, cumprem papel fundamental. É a partir da dicotomização da vida que estes complexos se constituem como bases que forjam e conformam a afirmação/negação; identidade/ alteridade; naturalização/ banalização; que permeiam a vida, as relaçóes de produçáo e reprodução sociais. É por meio destas estruturas firmadas e forjadas pelo capitalismo que os valores surgem, pois de acordo com Lukács (2110b) "como o conhecimento dos homens, a arte de persuadir, a engenhosidade, a astúcia, etc., alargam por sua vez o círculo de valores e das valoraçóes." Para o autor parece que quanto mais desenvolvida e disciplinada uma sociedade, tanto mais esta adquire um caráter institucional.

Neste cenário, embora reconheçamos os limites das identidades identitárias, compreendemos que estas surgem no "vácuo" deixado pela perspectiva homogeinizante da perspectiva de classe que imperou até o início do século XXI. Não há como não reconhecer que as desigualdades materiais, de renda, propriedade, de acesso ao trabalho remunerado; educação; saúde, previdência e assistência social, tenham sido mediadas pelo processo de reestruturação produtiva. Também a derrocada do processo histórico socialista no leste europeu, implementação do neoliberalismo como mecanismo ideológico, político, econômico e de governo corroboraram para "emergência de um novo imaginário político centrado nas noçôes de "identidade" / "diferença", "dominação cultural" e "reconhecimento." (FRASER, 2006, p. 231-232).

Esta análise não representa uma tentativa de rebaixar ou menosprezar as políticas indentitárias, mas de estabelecer mediaçóes a partir da teoria crítica que possam nos apresentar e/ou fornecer bases para a construçáo de identidades-unitárias. Entretanto, diferente de Fraser, cujo objetivo vislumbra novas reformulaçóes por meio da segurança da redistribuição e o reconhecimento das identidades, a perspectiva aqui é a de que a realidade, sob a qual se manifestam as opressóes sobre as mulheres (que se materializam na exploração - dominação - opressão), só serão superadas se simultaneamente enfrentadas no processo de superação deste modo de produção e reprodução social, material e subjetivo, compreendendo, pois, os limites estruturais deste modo de produção e de sua sociabilidade. Neste sentido, e em conformidade com Mészaros (2002) há um impulso expansionista do sistema.

[...] extralimitação do capital por si mesmo em relação às mulheres traz força de trabalho a um número cada vez maior delas, sob o inexorável impulso expansionista do sistema: 
uma alteração que não pode se completar sem que se levante a questáo da igualdade de mulheres, eliminando no processo alguns tabus e barreiras anteriormente existentes.

Este movimento - que surge do indispensável impulso do capital para a expansáo e náo da mais leve inclinaçáo a uma esclarecida preocupaçáo emancipadora em relaçáo às mulheres - erra o tiro no momento oportuno. Náo apenas porque as mulheres têm de aceitar uma parcela desproporcional das ocupaçóes mais inseguras e mais mal pagas no mercado de trabalho e estejam na péssima situaçáo de representar 70 por cento dos pobres do mundo. $\mathrm{O}$ movimento também erra o tiro porque, em virtude do seu papel decisivo na família nuclear, as exigências que são (e continuarão a ser) jogadas em cima das mulheres são cada vez mais difíceis de satisfazer no cenário mais amplo, contribuindo para que qualquer 'disfunção social' seja associada à crescente instabilidade da família [...] como [...] a taxa de criminalidade juvenil [...]. Quanto maiores as 'disfunçôes sociais', maiores a carga e as exigências impostas às mulheres como eixo da família nuclear; quanto maiores esses pesos, menores as suas condições de lidar com eles, além do seu papel de ganha-pão, do 'segundo turno' depois do trabalho e afins. (MÉSZÁROS, 2002, p. 304-305, grifo do autor).

Malgrado, "o modo antitético de produção capitalista nega, pois, a cada instante, a liberdade jurídica que ele próprio criou em benefício de si mesmo". (SAFFIOTI, 2013, p. 30). Assim, não é à toa que as mulheres ocupem, no mercado de trabalho, as funçóes mais precárias, assim como, também, continuem a ser as maiores responsáveis pelo cuidado com a casa, se sobrecarregando com a "jornada interrupta de trabalho".

Cabe salientar que a inferioridade social da mulher é insuficiente para levála à organizaçáo de um movimento feminista único, pois o que particulariza a luta feminista são os travejamentos dados pelas diferenças sociais, econômicas e culturais que refletem outras demarcaçóes sobre a luta feminista-mulheres.

Quando Elizabete Souza-Lobo (1991) apontou que há no movimento feminista um recorte em relação aos movimentos de mulheres, a autora afirma que o movimento feminista seria inscrito por mulheres das classes médias e burguesas e, o movimento de mulheres, inscrito por mulheres trabalhadoras, cujas reivindicaçóes eram socioeconômicas e, neste sentido, estas remeteriam à situação estrutural das mulheres e aquelas (movimento feministas) à situação conjuntural e/ou superestrutural das mulheres.

Assim, o que se questiona é: qual identidade de gênero da mulher? Ou, quais as identidades de gênero das mulheres? 
Tomarmos os escritos de Fraser (2006) verificaremos que as análises sobre a opressão das mulheres, na maioria das vezes, partiram da perspectiva superestrutural, ou seja, das representaçáo nos padróes sociais de representação, interpretação e comunicação, de modo que refletiram em respostas inscritas e mediadas por políticas de representaçáo, deste modo, objetivando a mudança a partir da interpretação e comunicação, donde a transformação não se processa na estrutura, mas na subjetividade, no sentido do "eu de todas as pessoas".

Assim, Fraser (2006), ao tecer críticas sobre as políticas de representação, nos alerta para a especificidade de algumas categorias e/ou grupos sociais e sua diferenciação em relação aos demais. Desta forma, esta perspectiva presume a diferença como ponto de partida para construçáo de formas de igualdade formais. Por outro lado, também destaca a autora que, a perspectiva redistributiva incorre na homogeneização ou negação das diferenças dos grupos ou categorias sociais. "O resultado é que a política do reconhecimento e a política da redistribuição parecem ter com freqüência objetivos mutuamente contraditórios." (FRASER, 2006, p. 234).

Podemos verificar que ambas interpretaçóes expressam limites estruturantes. Para D'Atri (2008; 123), as respostas inscritas na perspectiva do feminismo da diferença correspondem à um segmento do movimento feminista, que consiste na demarcação das diferenças morfológicas, afim de denunciarem o androcentrismo. Nesse contexto, qualquer política de igualação reproduziria a desvalorização da feminilidade em "sua aspiraçáo por conseguir a equiparaçáo com os direitos que o patriarcado outorga exclusivamente aos homens."

Em contraposição à esta perspectiva, D’Atri (2008, p. 125), ao tomar como referência Célia Amarós, defensora da igualdade, aponto que as feministas da diferença, ao negarem a existência de algo que possa se qualificar como "genericamente humano", incorrem no dualismo ontológico irredutível.

Desse modo, "se náo existe humano sem sexualismo, conclui-se na impossibilidade lógica e ontológica do humano", ou seja, na negação de um universal que possa transcender a diferença dos sexos" (D’ATRI, 2008, p. 126). Essa negação é o retorno ao essencialismo biológico. Parte destas mediaçóes são compreensóes estruturalistas da realidade, donde o movimento feminista é compreendido em ondas e, o movimento da totalidade, fracionado à estruturas generificantes.

Neste sentido, ambas negam a perspectiva das relaçóes de gêneros determinadas pela produção e reprodução da vida subjetiva e material que divide e hierarquiza as relaçóes de gênero. Apreendidas a partir das determinaçóes das 
relaçóes de poder micro sociais, são apartadas de uma relação com a totalidade na qual o sexo se constituiria também como uma relação social de produção.

D’Atri (2008) assinalou que tais equívocos quase irresolvíveis guardam relação estreita com o horizonte histórico, teórico e social em que se insere atualmente a opressão da mulher. Segundo a autora, é preciso superar a ingenuidade do Estado que media essas relaçóes de acesso à justiça, igualdade e equidade.

O Estado moderno capitalista consegue se divorciar 'mais e mais' da sociedade que lhe concebeu, como bem diz Engels, só a custas de eliminar de algum modo as distinçôes de nascimento, de classe, de educação e de profissão. $\mathrm{O}$ Estado burguês consegue esse divórcio separando as esferas da política e da economia de maneira fetichista; separando o ser humano em homem (burguês) por um lado e cidadáo pelo outro. Sua proclamação de que todo cidadão é igual perante a lei é a máxima expressão de liberdade e da igualdade perante a lei e a máxima expressão de liberdade e de igualdade jamais alcançada nos marcos de um sistema baseado na exploração de uma classe por outra. (D'ATRI, 2008, p. 127).

No nó que articula as determinaçóes de opressão, consubstancialmente manifestas pelo sexismo - racismo - e classe social [acrescentamos a sexualidade], ficam evidentes os limites da luta em si pela igualdade formal em detrimento da igualdade substancial. para que na vida concreta, desigual, injusta e baseada na exploração do homem pelo homem, as diferenças ao acesso à propriedade, educação, etc., continuem existindo.

Nessa prerrogativa é preciso corroborar com D’Atri (2008; 128), para quem o direito é concebido como "direito à desigualdade", similar à perspectiva marxiana.

O direito só pode constituir, por natureza, na aplicação de uma medida igual; mas os indivíduos desiguais (e não seriam indivíduos diferentes se năo fossem desiguais) só podem se medir sempre pelo mesmo parâmetro, sempre e quando lhe enfoque desde um ponto de vista de igual, sempre e quando lhe observem somente um aspecto determinado. (MARX, 2012, p.32).

Assim, é preciso entender que a luta pela emancipação das mulheres, unicamente como busca pela igualdade [por meio da inclusão num sistema cujo mote é a exclusão], é tender ao reformismo. A conversão do servo em trabalhador assalariado e presumidamente livre dos laços comunitários o 
estabeleceu como indivíduo capaz de vender a sua força de trabalho. Entretanto, o contrato que a partir daí se estabeleceu impôs a liberdade, cujo exercício oculta a profunda desigualdade entre os donos dos meios de produção e os trabalhadores, como também oculta a desigualdade entre o homem e a mulher.

\section{Algumas considerações}

"O homem rico é simultaneamente o homem carente de uma totalidade de manifestações humana de vida. $\mathrm{O}$ homem na qual sua efetivação própria existe como necessidade, interior, como falta". (MARX, 2010, p. 113). Tomando como ponto de chegada esse trecho de Marx, queremos pontuar que a riqueza potencialmente humana, sua diversidade, sexualidade, relaçóes sociais com a política, estética, filosofia e ética é incompatível como o modo de produção e reprodução vigente.

As formas como este sistema vigente buscar responder as carências humanas também é incompatível como o modo de produção e reprodução que vigora na nossa sociedade.

Embora consideramos que na luta de classe, acesso a direitos sociais, às políticas sociais para o exercício da participação, representação e do reconhecimento, sejam ferramentas táticas, afiançamos que só a unidade da classe trabalhadora, o horizonte estratégico de superação deste modo de produção é que impulsionará atividades humanas vitais e satisfatórias.

O desafio é que os movimentos e as categorias heterogenias constitutivas e constituintes da classe trabalhadora compreendam-se como sujeitos, autores do significado de vontades e atividades vitais.

Somente se nos tornarmos reais sujeitos de nossas vidas enquanto coletivo e não indivíduos particulares é que conseguiremos qualitativamente aproximarnos de uma igualdade e equidade substantivas.

\section{Referências}

ANTUNES, Ricardo; ALVES, Giovanni. As mutaçóes no mundo do trabalho na era da mundializaçáo do capital. Educaçáo \& Sociedade: Revista de Ciência da Educação, Campinas, v. 25, n. 87, p. 335-351, maio/ ago. 2004. Disponível em: http://www.scielo.br/pdf/es/v25n87/21460.pdf. Acesso em: 24 de maio 2012.

ANTUNES, Ricardo. Adeus ao trabalho: ensaio sobre as metamorfoses e a centralidade do mundo do trabalho. 4. ed. São Paulo: Cortez, 1997. 
ANTUNES, Ricardo. Os sentidos do trabalho. São Paulo: Boitempo, 1999.

BARBALET, Jack. A cidadania. Lisboa, Editora Estampa, 1989.

BOSCHETTI, Ivanete. Assistência social e trabalho no capitalismo. São Paulo, Cortez, 2015.

CISNE, Mirla. DANTAS. Maressa. Fauzia Pessoa. "Trabalhadora não é o feminino de trabalhador": superexploração sobre o trabalho das mulheres. Argumentum, 9 (1), p. 75-88. Disponível em: http://www.periodicos.ufes. br/argumentum/article/ view/13722. Acesso em: 02 de abril 2018.

CISNE, Mirla. Feminismo e consciência de classe no Brasil. São Paulo: Cortez, 2014.

D'ATRI. Andrea. Páo e rosas: identidade de gênero e antagonismo de classes no capitalismo. Editora. Iskra. 1. ed. Sáo Paulo, 2008.

FRASER. Nancy. Da redistribuiçáo ao reconhecimento? Dilemas da Justiça numa era pós Socialista. Cadernos de campo, São Paulo, n. 14/15, p. 1-382, 2006. Disponível em https://www.revistas.usp.br/cadernosdecampo/article/ viewFile/50109/54229. Acesso em: 20 de março 2018.

GONZAGUINHA. É. LP Coraçóes marginais. Moleque/WEA, 1988.

LESSA, Sérgio. A emancipação política e a defesa de direitos. In: Serviço Social e Sociedade ${ }^{\circ}$ 90. SP, Cortez, junho de 2007.

LUKÁCS, Georg. Reproduçáo. Disponível em: http://sergiolessa.com/ ontologia_all/Ontologia_all/CapReproducao/NovaTraduc/NovaTradu cReprod.doc. Acesso em: 21 de junho 2010b.

LUKÁCS, Georg. Trabalho. Disponível em: http://sergiolessa.com/ ontologia_all/Ontologia_all/CapTrabalho/Trabalh_ivo.doc. Acesso em: 21 de junho 2010a.

MARSHAL, Theodore H., "Cidadania e classe social". In: Cidadania, classe social e status, Rio de Janeiro: Zahar, 1967.

MARX, Karl. Assim chamada acumulação primitiva: o capital. Volume 1, Livro Primeiro, Tomo 2, Capítulo XXIV. São Paulo. Ed. Victor Civita, 1984.

MARX, Karl. Crítica do Programa de Gotha. São Paulo: Boitempo Editorial, 2012.

MARX, Karl. Manuscritos econômico-filosóficos. Trad. Jesus Ranieri. São Paulo: Boitempo, 2010. 
MÉSZÁROS, István. A montanha que devemos conquistar: reflexôes acerca do Estado. São Paulo, Boitempo, 2002.

SAFFIOTI. Heleieth. A mulher na sociedade de classes: mito e realidade. Expressão Popular. São Paulo, 2013

SILVA, Tomaz Tadeu da. A produçáo social da identidade e da diferença. In: SILVA, Tomaz Tadeu. (org.). Identidade e diferença: a perspectiva dos estudos culturais. Petrópolis: Vozes, 2000.

SOUZA LOBO, Elizabeth. A questáo da mulher na reprodução da força de trabalho. Perspectiva, São Paulo, v. 4, p. 43-47, 1981.

SOUZA LOBO, Elizabeth. A classe operária tem dois sexos. São Paulo: Brasiliense, 1991. 


\section{CAPÍtUlO 13 \\ EM BUSCA DE NOVAS PRÁTICAS DIDÁTICAS NO ENSINO DE HISTÓRIA: O REGIME DE EXCEÇÃO NA DITADURA CIVIL-MILITAR}

André Luís Monteiro Ferreira Lopes Maria do Socorro de Souza Araújo

\section{Introdução}

A ditadura civil-militar foi um período marcado pela implantação de um regime autoritário em que as liberdades individuais e de grupos sociais foram suplantadas por uma grande repressão política e social juntamente com a censura dos meios de comunicação; aliado a essa repressão aconteciam as torturas de presos políticos que enfrentavam esse regime de exceção. Esse regime teve como pano de fundo conter a ameaça comunista que na visáo de muitos traria um regime antidemocrático ao Brasil, sendo essa ameaça uma das justificativas que levaram os operadores do regime militar a utilizar a tortura para encontrar os propensos comunistas ou seus colaboradores no intuito de conter esse avanço comunista.

Esse movimento teve bastante influência dos Estados Unidos da América (EUA) e foi amplamente divulgado por meio de doutrinas de segurança nacional desenvolvidas em escolas superiores de guerra bem como recebeu generosos investimentos financeiros. Desde a década de 1930, o sentimento anticomunista foi se tornando algo presente no seio das Forças Armadas, na Igreja Católica e em grande parte das famílias católicas e nos políticos conservadores. Com o passar do tempo, esse movimento teve seu ápice durante a Segunda Guerra Mundial, na qual "O sentimento anticomunista de nossas Forças Armadas iria ser sedimentado com a participação brasileira na Segunda Guerra Mundial, ao lado dos chamados aliados, mais especificamente, junto ao V Exército dos EUA na Campanha da Itália”. (AQUINO, 2004, p. 58).

A contribuição das forças militares brasileiras na Itália foi importante para a vitória dos aliados e esse elemento foi importante para aproximação dos militares brasileiros do pensamento das Forças Armadas dos EUA frente à disputa entre o comunismo e o capitalismo, influenciando então a cúpula militar brasileira a se alinhar totalmente ao pensamento anticomunista que estava cada vez mais presente na doutrina militar brasileira. 
A década de 1960 foi um período no qual ocorreu o controle em vários setores da sociedade, em que o governo estava nas mãos dos militares, mas com grande influência dos empresários e latifundiários que foram peça importante no desenrolar do golpe de 1964. Após 33 anos do fim dessa ditadura, o tema ainda é bastante discutido no Ensino de História, sendo um dos temas do currículo escolar que traz muitas discussóes e, devido a isso, deve ser trabalhado em sala de aula com maior afinco dando abertura para os alunos participarem ativamente sem deixar de lado os estudos historiográficos sobre o assunto.

Pela importância desse tema tivemos a preocupaçáo de que os alunos realmente compreendessem esse momento fatídico da história brasileira e os desdobramentos tanto para o passado como para os períodos posteriores. Como professores devemos ter a preocupação de conseguir orientar o aluno a compreender as questóes relativas a esse conteúdo e superar o distanciamento que existe do tema evitando cair em situaçóes do senso comum. Neste processo, o professor deve buscar várias maneiras para construir esse conhecimento com o aluno. Compreendemos que apenas uma aula expositiva não seja suficiente para romper os elementos do senso comum e as influências às vezes negativas no sentido argumentativo que os alunos já construíram sobre o assunto.

Nessas inquietaçóes de como trabalhar o assunto fomos atrás de práticas exitosas e nos deparamos com algo bastante interessante que foi a técnica do Debate de Opiniáo, que causa maior interesse nos alunos, “[...], pois este representa uma ferramenta para compreender um tema controverso por diferentes pontos de vista [...].” (NASCIMENTO, 2015, p. 46). Então, o debate se encaixa na compreensão do conteúdo, principalmente pelo fato da Ditadura ser um tema controverso, o que tem por finalidade levar o aluno a buscar argumentos e formar, assim, opinióes diferentes. Fazendo isso, ele tem contato com as características desse momento histórico.

\section{Produção historiográfica: a ditadura civil-militar}

Nos últimos quinze anos tem se intensificado a produção historiográfica sobre a Ditadura civil-militar e podemos considerar este tema como um dos mais debatidos nos meios acadêmicos e com uma vultosa produção de artigos, livros e temas de vários simpósios e congressos pelo Brasil a fora. Autores que tratam do tema regime militar foram importantes para construção da experiência didática e construção desse artigo, dentre os quais podemos evidenciar Selva Guimarães Fonseca que expõem alguns pontos pesquisados como o Ensino de História durante o governo militar e a influencia exercida 
pelo controle do governo nesse período. Desse modo, "os conteúdos a serem ensinados na escola, em todas as áreas do conhecimento, são planejados e sistematizados pelos órgãos governamentais [...].” (FONSECA, 1993, p.55).

Para construçáo deste texto foi feito um recorte do tema regime militar evidenciando o quesito econômico no que tange ao momento que ficou conhecido como Milagre Econômico ${ }^{1}$. Uma produção bibliográfica foi muito importante para entendermos essa abordagem de forma mais densa do que encontramos nos livros didáticos, que foi a obra "1964-2004: 40 anos do golpe", organizada por Fico e Araújo (2004), que contém vários artigos relacionados à Ditadura militar. Voltando ao tema Milagre Econômico, destacam-se os estudos de Francisco Oliveira (2004) e Wilson Cano (2004) que fazem uma argumentação sobre as questóes econômicas que desembocaram na Ditadura desde o processo de industrialização do Brasil na década de 1940. Tais argumentaçóes estão envolvidas em um contexto de investimentos estrangeiros e posteriores movimentos populistas presentes em governos anteriores ao regime militar como o de Juscelino Kubitschek (JK) que contribuiu para uma crise econômica.

É muito importante para nós professores de a Educação Básica estar em contato com essas produçóes acadêmicas para ampliarmos reflexôes inerentes dessas discussóes e não ficarmos tão presos a conteúdos apenas dos livros didáticos. A partir de essas discussôes historiográficas novas discussôes podem ser vivenciadas e trazidas para a sala de aula, uma vez que: "Até alguns anos atrás eram poucos os historiadores que se debruçavam sobre o tema. Hoje, a pesquisa sobre os mais diversos aspectos do período do regime militar está se tornando uma área nobre da nossa historiografia”. (FICO, 2004, p. 12).

Considerando a importância das pesquisas sobre o tema Ditadura militar, podemos fazer um estudo da produção historiográfica do tema escolhido para essa pesquisa que é a Ditadura civil-militar, mais especificamente sobre o elemento Milagre Econômico. Assim, partimos de produçóes que abordam esse crescimento econômico vivido durante parte do regime militar que nos coloca num contexto de aprofundamento das discussóes e novos enfoques.

Analisando algumas produçóes historiográficas como Cano (2004) e Oliveira (2004), percebemos que estas buscam estabelecer uma relação dos regimes ditatoriais com o crescimento econômico brasileiro, principalmente

1 Entre os anos de 1968 e 1973, o Brasil viveu um expressivo crescimento econômico que contribuiu para o fortalecimento do regime militar. Chamado de "Milagre Econômico", esse crescimento esteve relacionado a políticas econômicas do Governo Castelo Branco e suas repercussóes nos anos seguintes. 
relacionando com a questão industrial, evidenciando que houve bastante controle das classes operárias nesses períodos por parte dos governos. Tal controle se justifica devido ao alinhamento do Brasil ao bloco capitalista liderado pelos EUA que temiam uma aproximação das classes trabalhadoras das fábricas dos países sob sua influencia ao socialismo representado pela União Soviética, juntamente com uma organização no processo de acumulação de capital tanto para as empresas nacionais bem como as empresas de capitais estrangeiros.

No contexto autoritário a partir de 1930 percebe-se a presença do populismo $^{2}$ que trouxe uma postura de negociação no intuito de atender alguns elementos reivindicatórios dessa classe trabalhadora urbana mantendo, de certa forma, o controle sobre esta camada, diferentemente do período ditatorial de 1964 que excluiu os trabalhadores do cenário político com forte controle sobre os sindicatos, tal qual como aconteceu durante o getulismo, no qual "o regime político de 1964-1984 caracteriza-se pelo oposto no que respeita às relaçóes com a classe trabalhadora, o movimento sindical e as classes burguesas. Dir-se-ia tratar-se não de regime de inclusão, mesmo tutelada, mas de exclusão da política." (OLIVEIRA, 2004, p. 221).

Nessa produção historiográfica pode-se perceber que o "Milagre Econômico" foi um processo que teve influencias de períodos anteriores à Ditadura militar de 1964, que está ligado ao processo de mudança da economia brasileira a partir de 1930 com os investimentos na indústria deixando aos poucos a economia pautada na exportaçáo primaria onde a indústria passou a ser o principal foco da economia brasileira.

É com a política econômica de recuperação implantada pelo governo Vargas que o mercado nacional se tornaria cativo dessa indústria, deslocando-se o centro dinâmico da economia, via processo de industrialização, que passaria a comandar seu crescimento e sua evoluçâo. (CANO, 2004, p. 226).

A industrialização passou a ter um papel fundamental na economia tornando-se o motor do desenvolvimento econômico e na substituição de importados. Podemos perceber que os governos Vargas, apesar de possuírem cunho nacionalista, trouxeram a fundamentação econômica que viabilizaria

2 Populismo pode ser compreendido como um movimento que atribui importância ao povo, às classes menos favorecidas, cuida-se delas e, assim, conquista-se sua confiança, o que permite que se exerça um autoritarismo consentido, uma dominação que não é percebida por quem é dominado. (OLIVEIRA, 2004). 
mais tarde o crescimento dos índices econômicos em parte dos governos militares em sintonia com a ordem econômica mundial. A criação de estatais colocando o Estado no seu papel de organizador da economia, a substituiçáo de importados e a crescente urbanização, consequentemente foi necessário à utilização de capital estrangeiro para investimento nas infra-estruturas de indústrias pesadas necessárias para o desenvolvimento industrial no país. (OLIVEIRA, 2004)

O governo desenvolvimentista de $\mathrm{JK}$, herdeiro desse processo industrializante, deu continuidade nesse processo de crescimento implementando novos procedimentos como a concessáo de subsídios e controle da entrada de capital de risco e controle tarifário com o objetivo de proteger o crescimento industrial brasileiro. Além disso, destaca-se também o Plano de Metas de JK que prezava pelo investimento em produção de energia elétrica e desenvolvimento dos transportes. "Considerando o período de implantaçáo dessas metas e seu amadurecimento - 1956-1962 -, o PIB ${ }^{3}$ cresceu à taxa média anual de 7,9\% e a indústria de transformação à de 10,0\%, expandindo a urbanização, que passava 45\% da população total." (CANO, 2004, p. 229).

Mesmo com todo esse crescimento, a economia brasileira era frágil, o sistema financeiro começou a entrar em crise, gerando o aumento da inflação, o aumento da dívida pública e a diminuição dos investimentos. Em razão disso, a partir de 1961 ocorreu a diminuição do PIB. Além dos problemas econômicos, as questóes sociais em vários setores estavam em dificuldades causando uma grande crise sócio-econômica. Houve um agravamento desses problemas socioeconômicos durante o governo de João Goulart que trazia para o debate a introdução de reformas de cunhos sociais abrangendo as áreas da reforma agrária, reforma política e fiscal que não agradava vários setores da sociedade com pensamento conservador. "O conjunto desses problemas foi politicamente canalizado pelos setores progressistas da sociedade, no movimento chamado 'Reformas de Base', entre 1959 e 1964, quando entáo a direita reacionária desencadeia o Golpe Militar de abril de 1964.” (CANO, 2004, p. 230).

Diante desses problemas econômicos e sociais, o governo ditatorial procurou enfrentá-lo com uma série de reformas econômicas aplicadas pelo chamado Programa de Ação Integrada do Governo (PAEG). A base desse plano eram as reformas das estruturas, a economia e combate a inflação:

3 Produto Interno Bruto (PIB). 
Criação da correção monetária para títulos públicos e privados; reforma tributária; criação do Banco Nacional de Habitação, para financiar a política habitacional; substituição da estabilidade no emprego pela criação do Fundo de Garantia por tempo de Serviço (FGTS); o Acordo de Garantia de Investimentos, assinado com o governo norte-americano. (CANO, 2004, p. 230).

Apesar de essas medidas terem surtido efeito contribuindo para queda da inflaçáo e também favorecendo o crescimento industrial, esse período do chamado Milagre Econômico foi um momento da grande concentraçáo de renda, ou seja, esse crescimento econômico náo beneficiou toda a sociedade brasileira, essa elevação da renda ficou mais na acumulação de capital dos grandes empresários industriais e latifundiários. O que aconteceu com relação à classe trabalhadora foi o achatamento dos salários que segundo as novas regras salariais não permitia o aumento dos salários em uma velocidade maior que o aumento da inflaçáo. (CANO, 2004).

\section{Livro didático como importante ferramenta para o ensino de história}

O livro didático se mantém ainda hoje como uma importante ferramenta para o ensino de História nas escolas da Educação Básica, mesmo com o advento da internet que disponibiliza uma gama de conteúdos em vários tipos de mídias, como é o caso dos vídeos, etc. Geralmente os professores tendem a utilizar o livro didático como um último recurso, pois acreditam que o livro é a única ferramenta em que ele pode encontrar subsídios para organizar suas aulas, atividades referentes aos conteúdos estudados e avaliaçóes. Já existem outros casos em que o professor uso o livro didático como mais um elemento didático num elenco diversificado de mecanismos pedagógicos.

O livro didático possui sua importância na Educação Básica pelo fato de grande parte dos professores o utilizarem como única ferramenta em sala de aula passou-se a entendê-lo como algo que deveria passar por uma criteriosa análise para compreender qual a sua influencia no ensino e aprendizagem de História além dos aspectos didáticos.

Devido a sua inserção e importância em sala de aula, os livros didáticos passaram a ser considerados objetos de análise para se pensar a aprendizagem histórica. Como material complexo, a análise deste material vai além dos seus aspectos puramente didáticos. (CARVALHO, 2015, p. 291). 
Desde a melhoria do Programa Nacional do Livro Didático em 1995 e criação de Leis de Diretrizes e Bases da Educação Nacional (LDB) em 1996, o livro didático passou a ser distribuído pelo governo federal, a partir daí, tornando-se mais presente e difundido nas escolas públicas no Brasil. De maneira geral os livros didáticos são escolhidos pelos professores das matrizes curriculares por meio de análise de exemplares disponibilizados pelas editoras de três em três anos, em que são escolhidas três opções. $\mathrm{Na}$ maioria das vezes, primeira opção é a que chega às escolas para ser utilizado por professores e alunos.

Como o livro didático é ainda utilizado nas escolas, podemos analisar o conteúdo desse material tendo como referencial outras leituras bibliográficas dos temas que fazem parte do currículo escolar e são discutidos em artigos científicos, livros, entre outros. Sendo assim, o objeto de análise foi o Milagre Econômico, conteúdo disponibilizado no material didático utilizado na escola que atuamos. Neste caso, o livro analisado foi o "História 3 - O mundo por um fio: do século XX ao XXI", de Ronaldo Vainfas, Sheila de Castro Faria, Jorge Ferreira e Georgina dos Santos (VAINFAS et al., 2010).

Nessa análise foi verificado que o livro traz alguns elementos didáticos interessantes, como a utilização de imagens e textos introdutórios, além de outros elementos norteadores que trazem a discussão para outra dimensão, como a cultural. Como exemplo é utilizado no material alguns documentos, relatos relacionados ao assunto discutido no livro, encontra-se no topo das páginas uma linha do tempo cronológica relacionando os principais acontecimentos do período em estudo. Com isso, entendemos que:

Os autores demonstraram preocupação em tornar a história
uma disciplina viva e relacionada com a experiência prática
dos alunos. Como também indicaram a importância de
abordar novas temáticas além daquelas ligadas às esferas
políticas e econômicas. A presença de vários boxes e fontes
se insere nesta perspectiva de novas abordagens de ensino a
partir do questionamento às fontes. (CARVALHO, 2015,
p. 295).

O Milagre Econômico dentro do contexto dos governos militares foi um dos elementos que se tornou uma das justificativas do regime militar. Nessa análise foi possível verificar que o livro didático coloca o assunto de maneira coerente e didática, o que facilita o entendimento dos discentes. Uma característica desse livro em praticamente todos os conteúdos, no caso do Milagre Econômico, os autores colocam os aspectos principais que viabilizaram esse crescimento 
econômico durante os anos de 1968 a 1975, como a conjuntura econômica internacional e os empréstimos estrangeiros que colaboraram na construção da infra-estrutura necessária para o crescimento econômico na concepção dos governos militares.

O mesmo livro evidencia também o investimento desses governos militares na indústria e agricultura mecanizada, mas explicita de maneira superficial os índices desse crescimento econômico como o PIB por exemplo. Possui algumas imagens que ilustram o consumismo característico desse período, e faz também uma ligaçáo com o ufanismo brasileiro incentivado pelo governo ditatorial. De modo geral, o livro consegue deixar claro para os alunos o que foi esse momento do Milagre Econômico, ressaltando suas características peculiares em consonância com a produção historiografia.

\section{Registro da experiência didática de ensino}

Quebrando o desenvolvimento linear do conteúdo do livro didático, fizemos uma antecipação de conteúdo e, no $2^{\circ}$ Bimestre letivo de 2018, iniciamos o estudo do período da Ditadura civil-militar (1964-1985) com as turmas dos terceiros anos do Curso Técnico em Agropecuária integrado ao Ensino Médio do Campus Colorado do Oeste do Instituto Federal de Rondônia - IFRO. Este é um assunto de importância e de controvérsia no contexto social, que traz grandes dúvidas, atitudes e concepçóes falaciosas e desconectadas com a historiografia.

Nas minhas experiências como professor de História, sempre vi a necessidade de trabalhar de forma enfática todas as características e acontecimentos relacionados a esse tema. Sempre acreditei que o professor deveria conhecer o conteúdo de forma aprofundada para poder ensinar aos alunos de forma responsável. Contudo, devido às realidades vividas anteriormente nas escolas estaduais do Estado de Rondônia no município de Vilhena, onde trabalhei por sete anos antes de ingressar nos quadros da Rede Federal de Ensino, em que as questóes de indisciplina e falta de interesse eram muito presentes, essa forma de ensinar não acontecia de maneira tranqüila. $\mathrm{O}$ conhecimento dos temas se tornava uma estratégia que na minha concepção iria prender a atenção dos discentes, mas esse aprofundar dos temas de minha parte, na maioria das vezes, era pautado no estudo do livro didático e na busca de algum site da internet que trouxesse algo diferente para enriquecer as aulas expositivas que usava. $\mathrm{O}$ tempo nas escolas públicas do Estado é algo escasso pela grande quantidade de 
horas que ficamos em sala de aula, isso com certeza influencia de maneira negativa na leitura de textos acadêmicos que trazem um enfoque mais aprofundado dos temas.

Basicamente aulas expositivas dialogadas com esquemas são utilizadas e dispostas na lousa para trazer explicaçóes mais aprofundadas possíveis para chamar a atençáo do aluno, por meio de analogias. Quando possível procurava usar slides para trazer uma ilustração do assunto. Infelizmente, até mesmo como uma forma de resistência por parte dos alunos àquelas aulas muitas vezes maçantes e outros fatores externos como desestrutura familiar e a busca de uma aula diferenciada característico das geraçóes atuais, geravam bastante indisciplina e desinteresse o que dificultava a participaçáo dos alunos na discussão do conteúdo tornando a aula um monólogo, pois não havia grande participação dos discentes, alunos dispersos e desconectados com o assunto, refletindo no baixo rendimento nas avaliaçóes escritas e trabalhos. A reavaliação é um processo constante na vida profissional de um docente, principalmente quando este sai da sua zona de conforto na busca por mudanças e, nesse processo, percebe-se que esse desinteresse pelos conteúdos por parte dos alunos está muito ligado ao método de trabalhar os temas durante as aulas.

Nesse processo de reavaliação profissional comecei a pensar outras maneiras de trabalhar os conteúdos que poderiam contribuir de maneira mais eficaz no aprendizado dos alunos, não poderia e não queria trabalhar mais somente da forma que trabalhei pautado basicamente em aulas expositivas, não que essas não sejam importantes, mas gostaria de ver uma maior participação dos alunos, lendo, discutindo, buscando informaçôes em outras fontes além do livro didático. Essa mudança de postura culminou com a adoção de outras experiências didáticas que foram aplicadas em sala de aula.

O foco desse texto foi o relato de uma experiência didática utilizada e que me levou a ler sobre o tema na historiografia e fazer uma análise do livro didático e a partir de todo esse estudo mencionar a experiência didática que foi a utilização de um debate dirigido para abordar o tema da Ditadura militar. Esse debate foi realizado no contexto educacional citado no início do texto: "Esse tipo de atividade irá expor aos alunos um referido assunto, e instigá-los a emitirem sua opiniāo, dando lugar a discussóes pertinentes." (NASCIMENTO, 2015, p. 44). Acreditei que, como reflete a citação, esse método chamaria atenção dos alunos e traria esse aluno para uma conexáo maior com o tema saindo daquela apatia que me incomodava cada vez mais. Então, comecei a pesquisar em artigos como fazer um debate com qualidade, sempre com a preocupação de fugir daquele modelo de debate aleatório sem nenhum tipo de preparação prévia e organização. 
Foi proposto para os alunos o tema Ditadura civil-militar gerando bastante euforia por parte dos alunos, pois eu estava propondo uma atividade diferenciada que os tirariam daquela aula maçante onde eu falava por vários minutos explanando as principais características dos temas estudados provocando em grande parte desatenção, e não compreensão do conteúdo. Foi informado para os discentes na sala de aula e via e-mail da turma de maneira bem antecipada (duas semanas) todo cronograma dessa atividade constando o dia do debate em cada turma, o dia e horário do meu atendimento ao aluno, orientaçóes acerca de como pesquisar e que as turmas dos quatro terceiros anos que existem na escola iriam se dividir em dois grupos em cada sala, um grupo contra e outro a favor da Ditadura civil-militar.

A partir dessa divisão feita por mim, tomei a decisão de dividir os grupos por uma questão de organização na época da aplicação da atividade, pois temia que os grupos ficassem desiguais ou que gerasse muita desorganização o que causou um pouco de transtorno, pois os alunos foram obrigados a pesquisar argumentos que náo condiziam com sua forma de pensar o regime militar, os alunos teriam que buscar argumentos para serem utilizados no dia do debate em sala de aula com data definida no cronograma. Um fator interessante foi que os dois grupos de cada sala foram divididos de acordo com a chamada, ficando alguns discentes em lados diferentes a sua posição de fato, por exemplo, alunos que eram contra a Ditadura, ficaram no grupo a favor da Ditadura, fazendo com que esse aluno buscasse argumentação favorável ao golpe militar e vice-versa.

Os alunos se dedicaram à atividade. $\mathrm{O}$ fato de o assunto estar em voga atualmente e também a atividade sendo diferenciada fugindo daquele contexto rígido das aulas expositivas contribuiu nessa busca eufórica pela argumentação de cada um dos lados. Os alunos não ficaram sem auxílio nas suas pesquisas e contaram também com atendimentos que os auxiliavam na busca de sites e fontes nas quais poderiam pesquisar argumentos plausíveis, além da biblioteca da escola.

Depois da movimentação na pesquisa, os discentes se organizaram para utilizar seus argumentos no dia do debate. Previamente foram definidos seis alunos de cada lado para fazerem o uso da palavra colocando para a turma os argumentos que justificavam o posicionamento de cada lado. Depois da fala cronometrada desses componentes dos grupos, outros alunos poderiam participar expondo seus argumentos e debatendo, cumprindo as regras que consistia primeiramente no respeito aos colegas, respeitando as falas de cada um, não insultando os colegas e falando de maneira organizada. 
Durante a pesquisa, mediei o debate cronometrando o tempo e contendo os ânimos que às vezes se exaltavam. Outro fator importante foi a definição de um aluno redator que anotaria os argumentos dos dois lados, a favor e contras ao regime militar, para uma discussão e orientação feita por mim. Houve uma grande participação dos discentes na atividade, eles se dedicaram na busca de argumentos interessantes que fomentaram o debate, ao final fiz algumas consideraçóes e esclarecimentos ligados ao conteúdo e os ânimos se acalmaram. O importante, portanto, é mostrar que esse é o caminho: novas experiências, caminhar para além de um planejamento "engessado".

\section{Considerações finais}

O ensino de História, ou de qualquer outra disciplina, não deve ficar pautado apenas em um único elemento, mas deve englobar procedimentos e métodos didáticos diferenciados. $\mathrm{O}$ ensino deve acontecer sempre levando em conta os conhecimentos prévios dos discentes, suas peculiaridades, sua consciência histórica, pois é construído juntamente com o aluno e deve ser levado em conta que estudantes devem ser surpreendidos com experiências didáticas diferentes.

$\mathrm{Na}$ construção deste trabalho, conseguimos verificar alguns elementos importantes, isto é, uma análise criteriosa do livro didático deve ser efetivada como meio de verificar como preencher as lacunas que por ventura esse material possa apresentar ou mesmo para utilizar melhor os pontos fortes desse material, de modo a propiciar o desenvolveimento do senso crítico necessário às leituras e compreensão, o que nos leva a afirmar que somente foi possível analisar esse livro didático de maneira eficiente quando buscamos estudar as produçóes historiográficas relacionadas e esses conteúdos escolares, o que nos leva a construir uma relaçáo de troca entre aluno e professor.

No que tange a atividade desenvolvida nas turmas dos terceiros anos, ficou evidente essa construção de conhecimento entre professor e aluno. $\mathrm{O}$ discente se tornou parte integrante do processo de aprendizagem, por meio das pesquisas e discussôes dentro de cada grupo que foram construindo suas opinióes, alterando ou confirmando as suas maneiras de pensar. $\mathrm{O}$ aluno não foi apenas um receptor de conhecimento que somente o professor possui, eles tiveram interesse em buscar argumentos que pudessem contemplar o debate de seus grupos, mesmo se esses argumentos não coincidissem com sua forma de pensar.

Houve um reflexivo palpável nessa atividade que foi o crescimento quantitativo das notas bimestrais na maioria da turma, inclusive para alunos 
considerados medianos e com notas baixas essa prática trouxe uma compreensão maior do conteúdo que refletiu na melhoria das notas da avaliação escrita que também fazia parte das avaliaçóes daquele bimestre. Essa atividade náo foi compensatória apenas para os discentes, mas para mim que pude rever minhas práticas pedagógicas e perceber que esse rever foi muito gratificante, pois trouxe outros parâmetros de ensino, outras buscas que não faziam parte do seu universo escolar, como valorizar o trabalho escolar do discente, seu esforço e seu aprendizado.

\section{Referências}

AQUINO, Maria Aparecida de. Estado Brasileiro Pós-64: conceituação, abordagem historiográfica, ambiguidades, especificidades. In: FICO, Carlos; ARAÚJO, Maria Paula (org.). 1964-2004: 40 anos do golpe: ditadura militar e resistência no Brasil. Rio de Janeiro: 7 letras, 2004. p. 55-70.

CANO, Wilson. Milagre Brasileiro: Antecedentes e principais consequências econômicas. In: FICO, Carlos; ARAÚJO, Maria Paula. (org.). 1964-2004 40 anos do golpe: ditadura militar e resistência no Brasil. Rio de Janeiro: 7 letras, 2004. p. 226-239.

CARVALHO, Ana Paula Rodrigues. As histórias, os sujeitos, as narrativas: análise do regime fascista nos livros didáticos. História \& Ensino. Londrina, v. 21, n. 1, p. 289-306, jan./jun. 2015.

FICO, Carlos; ARAÚJO, Maria Paula (org.). 1964-2004: 40 anos do golpe: ditadura militar e resistência no Brasil: Rio de Janeiro, 2004.

FONSECA, Selva Guimarães. Caminhos da história ensinada. Campinas: Papirus, 1993.

NASCIMENTO, Carlos Bezerra do. Oralidade e letramento: o debate em sala de aula. 2015.107 f. Dissertação (Mestrado em Letras) - Universidade Federal do Rio Grande do Norte, Natal.

OLIVEIRA, Francisco de. Ditadura Militar e crescimento econômico: A Redundância autoritária. In: FICO, Carlos; ARAÚJO, Maria Paula (org.). 1964-2004: 40 anos do golpe: ditadura militar e resistência no Brasil. Rio de Janeiro: 7 letras, 2004. p. 219-225.

VAINFAS, Ronaldo et al. História: o mundo por um fio: do século XX ao XXI: volume 3. São Paulo: Saraiva, 2010. 


\section{Capítulo 14 \\ FORMAÇÃO LITERÁRIA \\ EM ESPAÇO SOCIOEDUCATIVO: \\ ENTRE LIVROS LITERATURA E HISTÓRIAS}

Rosangela Queiroz Garcia Leite Nogueira
Rosemar Eurico Coenga

\section{Introdução}

O presente estudo foi construído a partir de um trabalho de pesquisa realizado no Centro de Medidas Socioeducativos Feminino de Cuiabá CASE/MT, e faz parte do Programa de Mestrado Acadêmico em Ensino oferecido em conjunto pelas instituiçóes UNIC e IFMT.

$\mathrm{O}$ estudo justifica-se na crença de que as experiências e práticas de leitura/literatura protagonizadas por adolescentes em cumprimento de medidas socioeducativas poderá contribuir para uma alteração de suas subjetividades e, consequentemente, para a re (construção) de si, eis que o exercício da leitura proporciona a construçáo de sentidos.

Por intermédio de relatos de duas servidoras do Centro de Atendimento Socioeducativo de Internação Provisória e Internação Feminino - CASE, Polo Cuiabá/MT, buscamos conhecer as experiências de leituras de adolescentes em cumprimento de medidas socioeducativas. Tais servidoras evidenciaram um verdadeiro comprometimento e amor pela atividade de aproximação das obras literárias para com as adolescentes.

Entre os direitos do indivíduo de participar dos benefícios da vida civilizada, social, cultural e intelectual, está o direito à educação. A Constituição Federal, em seus artigos 205 e 214, assegura e disciplina a distribuição e implementação do direito à educação, extensivo a todos os brasileiros e, em especial, à criança e ao adolescente.

Em atendimento a esse comando constitucional, o Estatuto da Criança e do Adolescente - ECA/Lei 8.609/90 assegurou e ampliou tais normativas, posto que destaca a prioridade da ação educativa na aplicação das medidas socioeducativas, tais como receber escolarizaçáo e profissionalização; obrigatoriedade de atividades pedagógicas; atividades culturais; receber assistência religiosa, entre outros direitos não menos importantes.

Com base nos estudos elaborados pela Secretaria Especial dos Direitos Humanos. Parâmetros para formação do socioeducador (2006), uma proposta 
inicial para reflexão e debate sob coordenação técnica do professor e pedagogo Antônio Carlos Gomes da Costa, coordenador técnico do Socioeducação: Estrutura e Funcionamento da Comunidade Educativa, a socioeducação caracteriza-se como medida de dimensóes pedagógicas educacionais que visam construir junto aos adolescentes o desenvolvimento pessoal, propondo conceitos humanistas, pela reflexão de valores, tendo em vista a (re) socialização, integração com o meio e, principalmente, a interrupção da trajetória infracional do sujeito. Tais medidas amparam adolescentes entre 12 a 18 anos, permitindo, apenas para os casos expressos em lei especial, sua aplicação a pessoas entre 18 a 21 anos de idade.

O Plano Nacional de Atendimento Socioeducativo estabelece ainda: Diretrizes e Eixos Operativos para o SINASE ${ }^{1}$ prevê a formação educacional e profissional do adolescente, devendo, por consequência, a escolarização básica ser oferecida na unidade socioeducativa.

A vista disso, por meio de autorização judicial, adentrei no espaço Socioeducativo Feminino - CASE/MT, com proposito de conhecer as experiências de leitura das alunas adolescentes socioeducandas, oportunidade em que fui apresentada às conselheiras Jo e Máh, servidoras da SEJUDH, ${ }^{2}$ que, além de suas atribuiçóes diárias observadas pela SEJUDH, contribuem para a formação de leitura/literatura das adolescentes socioeducandas de forma voluntária e informal no espaço socioeducativo, independentemente do processo de escolarização ligado à $\mathrm{SEDUC}^{3}$, que também é realizado nas dependências do Centro de Atendimento Socioeducativo Feminino - CASE.

\section{Leitura como interação cultural}

Para Roger Chartier e Pierre Bourdieu (1996), a leitura deve ser entendida como uma prática cultural, portanto, plural, embora nem sempre essa pluralidade da leitura seja considerada pela sociedade. Para Chartier (1992), "ler é uma prática criativa que inventa significados e conteúdos singulares, não redutíveis às intençôes dos autores dos textos ou dos produtores dos livros." (CHARTIER, 1992, p. 214).

Ler é apropriar-se de um produto cultural, bem como entrar em contato com um objeto histórico e social, construído ideologicamente. Consequentemente,

1 Sistema Nacional de Atendimento Socioeducativo.

2 Secretaria de Estado de Justiça de Direitos Humanos - MT

3 Secretaria de Estado de Educação - MT 
a atividade leitora propicia um leque de experiências para os sujeitos, os quais passam a interagir com novas convicçóes e sentimentos, assim como traduzem novas formas de compreender o mundo e as relaçóes humanas (AGUIAR, 2013, p.154).

Tais experiências podem proporcionar ao sujeito leitor diferentes formas de autonomia, liberdade e poder. Dessa forma, Duster (2002, p. 110) define que "o leitor se forma com a liberdade para escolher sem obrigatoriedade, posto que o livro náo é material didático e o professor dever ir no caminho do interesse do sujeito leitor". Segundo a Autora, o leitor se constrói de forma heterogênea, mediante identificaçóes, gestos, práticas escolares e não escolares, bem como por meio de histórias contadas e contato com os livros. E, ainda, mediante as intervençóes de pessoas que apresentam a leitura em horizontes em que a liberdade, escolha e opção iluminam o trajeto do sujeito leitor.

Para Dalvi (2013, p. 75), contudo, os textos literários são apresentados em desarticulação com o mundo da vida, com a história e o contexto social econômico cultural, principalmente, para os alunos cuja situaçáo econômica seja desfavorável.

A autora ainda sugere que os trabalhos com a literatura, dentro ou fora dos espaços e tempos escolares, sejam distintos do ensino planejado e sistemático de literatura. Como já propôs Jorge Larrosa (2004), "literaturizar" a escola e a pedagogia, ao invés de escolarizar ou pedagogizar a literatura.

Nas palavras de Foucambert (1994, p. 135), o leitor "não é quem lê o livro que lhe é proposto, mas aquele que cria seus próprios meios de escolher livros que irá ler, que conhece os meios e os caminhos para encontrar e diversificar os textos ligados aos seus interesses".

$\mathrm{Na}$ visão de Paulo Freire (2000), o ato de ler é uma forma de conhecer o mundo, não se esgotando na decodificaçáo pura da palavra escrita ou da linguagem escrita. A leitura do mundo precede a leitura do texto, daí que a posterior leitura desta não pode prescindir da continuidade da leitura daquele.

Como bem observa Goldin (2012, p. 125), a atividade leitora nem sempre transforma o sujeito que lê. Contudo, a leitura pode ser uma forma de gasto, de gratuita liberaçáo de energia. Entende o autor que a leitura consumo, do ócio ou entretenimento merecia mais atenção das pessoas e instituiçóes encarregadas da formação de leitores.

Os estudos de Michèle Petit $(2009,2010)$ apontam que o papel do mediador de leitura aproxima o leitor dos textos, podendo, ainda, construir pontes entre o leitor e textos, "contaminando-os" pela paixão da leitura, que, possivelmente, intervirá na abertura de espaços e tempos onde o desejo de 
ler possa traçar novos caminhos, o que certamente poderá levar as crianças e os adultos a uma maior familiaridade e maturidade na abordagem dos textos escritos, contribuindo, assim, para o gosto pela leitura. Dessa forma, expóe Petit:

Assim, o iniciador aos livros é aquele ou aquela que pode legitimar um desejo de ler que não está muito seguro de si. Aquele ou aquela que ajuda a ultrapassar os umbrais em diferentes momentos do percurso. Seja profissional ou voluntário, é também aquele ou aquela que acompanha o leitor no momento, por vezes táo difícil, da escolha do livro. Aquele que dá a oportunidade de fazer descobertas, possibilitando-lhe mobilidade nos acervos e oferecendo conselhos eventuais, sem pender para uma mediação de tipo pedagógico. (PETIT, 2009, p.174-175).

O mediador, portanto, é aquele que "constroi pontes para universos culturais mais amplos" aos sujeitos leitores, assim como o que exerce um papel chave para que o leitor não fique sitiado entre alguns textos e, ainda, aqueles que proporcionam aos leitores uma diversificação de leituras.

Ainda na opiniáo da autora, o mediador pode ser um bibliotecário, um livreiro, um professor, um amigo, um assistente social, educadores de um modo geral, ou até mesmo um desconhecido que cruza nosso caminho, os quais muitas vezes desenvolvem um autêntico "trabalho terapêutico" para a vida do leitor.

Como diz a autora, o encontro com o livro coloca o leitor em movimento e lhe permite se conciliar com a sua vida interior, "suspensa, parada, fraturada pelo sofrimento psíquico". Salienta ainda a autora que os livros roubam um tempo do mundo das pessoas, mas eles podem devolver-lhes, transformandolhes, ainda (PETIT, 2010, p. 130).

Frisa a autora que a leitura é uma experiência singular, e toda experiência implica riscos para o leitor e para aqueles que o rodeiam. O leitor vai ao deserto, fica diante de si mesmo, a palavras podem jogá-lo para fora de si mesmo, desalojá-lo de suas certezas, de seus "pertencimentos" (PETIT, 2009, p. 147-148).

Por conseguinte, diz Petit, a função dos mediadores culturais de livros constitui auxilio dos leitores na compreensão da leitura como instrumento de organização e transformação da própria história. São esses mediadores culturais que criam uma "abertura psíquica" (Petit, 2010, p. 50), diante da qual o leitor poderá revisar o seu ser, ampliando seus caminhos para o seu desenvolvimento espiritual. 
Constatou a autora, durante suas pesquisas, que jovens críticos em relação à escola relataram, às vezes, um professor que soube transmitir sua paixão pela leitura, despertando nesses jovens a curiosidade, o desejo de ler e de descobrir, fazendo, inclusive, com que gostassem de ler textos difíceis. Percebeu, diz ainda a autora, que, mesmo com todas as dificuldades e mudanças enfrentadas nos programas educacionais, existe um professor singular capaz de iniciar os alunos em relação aos livros, sem que isso constitua dever cultural, ou seja, da obrigação austera (PETIT, 2009, p. 158).

Ademais, Petit (2010) aborda que não é a escola que desperta o gosto pela leitura, mas, sim, as práticas leitoras de um professor levado por sua paixão leitora, afirmando, ainda, ser a literatura "uma arte que se transmite mais do que se ensina", através de uma relação individual, sobretudo, no caso dos que não se sentem muito seguros a se aventurarem por essa via, tendo em vista sua origem social. É como se, a cada passo, a cada umbral que atravessem, sejalhes preciso receber uma autorização para ir mais longe. E, se não for assim, voltarão para o que já lhes é conhecido (PETIT, 2010, p. 166).

Petit (2009), contudo, adverte que o espaço íntimo que a leitura proporciona náo irá reparar o mundo das desigualdades ou da violência. No entanto, seguramente, favorecerá que crianças, adolescentes e adultos encaminhem-se mais no sentido do pensamento do que da violência, e, ainda, em algumas circunstâncias, permitirá a leitura abrir-se um campo de possibilidades, inclusive, onde parecia náo existir nenhuma margem de manobra (PETIT, 2009, p. 174 -175).

\section{Histórias de leituras no centro socioeducativo}

No Centro de Atendimento Socioeducativo de Internação Provisória e Internação Feminino - CASE/MT há um projeto não formalizado sobre leitura, de um modo geral, para com as adolescentes/socioeducandas submetidas a medida socioeducativa de internação. Esse trabalho é desenvolvido especificamente por duas servidoras, Jo e Máh ${ }^{4}$, que, além do oficio de conselheiras do CASE/MT, vêm contribuindo para a formação de leitura/literatura naquela unidade socioeducativa.

A intervenção literária realizada pelas conselheiras/mediadoras é um trabalho independente do processo de escolarização realizado nas dependências do Centro de Atendimento Socioeducativo Feminino - CASE/MT, razão pela

4 Embora possuíssemos o termo de assentimento firmados pela servidoras utilizaremos cognomes. 
qual dificilmente ocorrem trocas de experiências entre o corpo docente escolar e as conselheiras/mediadoras.

Ambas as servidoras são estáveis, vinculadas à Secretaria de Estado de Justiça e Direitos Humanos - SEJUDH-MT, sendo que, atualmente, exercem a atividade de conselheiras socioeducadoras, fazendo parte de um trabalho disciplinador e conscientizador cujo objetivo é voltado para a escuta das socioeducandas, através da elaboração de relatórios e instauraçóes sobre as atitudes comportamentais das adolescentes no espaço socioeducativo, cujos resultados são, a posteriori, encaminhados para o Juizado da Infância e Juventude.

O nascimento da biblioteca no espaço socioeducativo deu-se por iniciativa das conselheiras, que fazem também o papel de mediadoras de leitura, empenhadas na formação cultural das adolescentes. Nesse desiderato, as conselheiras se articularam para trazer alguns livros já existentes no CASE/ $\mathrm{MT}$, os quais foram reunidos e organizados em uma prateleira de aço na própria sala do conselho.

Com o intuito de diversificar o acervo, foram adquiridas várias obras literárias, por meio de doaçóes particulares e por funcionários do CASE/MT. Busca-se, ainda, adquirir constantemente novas obras, vez que há momentos em que as adolescentes manifestam o desejo de ler determinada obra especifica, a exemplo do que ocorreu com a obra "O Diário de Ane Frank" (2017), de Anne Frank, conhecida pelas adolescentes/socioeducandas através de citaçóes em outras leituras.

A princípio, as conselheiras/mediadoras Jo e Máh idealizaram o trabalho com a leitura/literatura no CASE/MT, para tirar as adolescentes do ócio, bem como para aliviar a agitação, que é constante, buscando-se, dessa forma, evitar a imposição de medidas sociodisciplinares aplicadas em face das internas que eventualmente cometam atos de indisciplinas, como por exemplo a suspensão por 21 dias do pátio livre 5 .

Dessa forma, Jo e Máh buscaram inserir os livros nos alojamentos/quartos e fora dos alojamentos (pátio livre), com o intuito de preencher a ociosidade, além de despertar o prazer e o desejo de ler de forma espontânea e com liberdade de escolha, até porque, conforme afirmam Jo e Máh, "no ambiente socioeducativo, esse é um dos poucos momentos em que as adolescentes/ socioeducandas têm a livre escolha do que desejam fazer".

5 Pátio livre: é um momento estipulado pelo CASE/MT, em que as adolescentes são liberadas de seus alojamentos/quartos para ficarem livremente, mas vigiadas pelos agentes (brincando, jogando, lendo etc.), no pátio do CASE. 
Constatam as conselheiras Jo e Máh que o contato com as obras literárias tem provocado grandes mudanças nas adolescentes, principalmente nos aspectos intelectual, cultural e comportamental, sendo isso perceptível, já que, no início de sua permanência no ambiente socioeducativo, as adolescentes lançam mão de livros com poucas páginas, para, à medida do contato com a leitura, optarem por obras com maior quantidade páginas, ficando, com isso, maravilhadas e agradecidas pela oportunidade de estarem em contato com os livros.

Outra mudança significativa avaliada pelas mediadoras/conselheiras Jo e Máh se refere ao universo linguístico, em relação ao antes e ao depois das práticas de leitura, visto que as adolescentes chegam ao espaço socioeducativo utilizando a linguagem própria de infratores (não culta), carregada de gírias, para, com o passar do tempo, e em razão, principalmente, do prazer da leitura, perceber-se uma completa mudança de suas identidades. E, dessa forma, as próprias jovens/adolescentes percebem que houve melhora em suas linguagens, bem como na ampliação de seu vocabulário, passando a náo mais utilizar com frequência a linguagem da gíria, característica de seus contextos sociais.

Observaram as conselheiras/mediadoras Jo e Máh, ainda, que a prática da leitura no ambiente socioeducativo tem contribuído grandemente com a educaçáo formal das adolescentes, visto que estas passaram a utilizar uma linguagem mais formal, o que favoreceu, inclusive, um melhor diálogo com o juiz.

A propósito, uma das conselheiras/mediadoras nos relatou ser comum uma adolescente dizer uma palavra e, nesse momento, admirada, mencionar que sequer sabia que existia tal termo: "Nossa! Nem sabia que eu conhecia essa palavra! É esse mesmo o significado dela?"

Relatam ainda as conselheiras/mediadores que as adolescentes/ socioeducandas passam a interpretar suas falas durante as oitivas, buscando se expressar com maior clareza e integralidade, visto que que suas falas serão transcritas para o juiz. Assim, floreiam suas linguagens com palavras novas, adquiridas espontaneamente através da formação cultural que a leitura lhes proporciona.

Dessa forma, observam as conselheiras/mediadoras, as adolescentes, por meio de suas experiências leitoras, passam a pensar mais, assim como organizam melhor suas falas e textos. E esse movimento é demonstrado e observado durante as atividades elaboradas pelas conselheiras no ato das oitivas, vez que as jovens/adolescentes relatam para o juiz seus comportamentos e/ou atitudes em desacordo com as normas socioeducativas durante a permanência no socioeducativo. 
Nesse diapasão, Michèle Petit nos diz que "graças a mediações sutis, calorosas e discretas" [...], durante o percurso de internaçáo das adolescentes, "a leitura começa a fazer parte de suas experiências singulares, de modo que os livros já não as desencorajavam nem os assustavam. Ao contrário, ajudavam-nas a encontrar palavras, a serem um pouco mais atores de sua própria história." (PETIT, 2009, p. 11).

É certo que a prática da leitura/literatura mediada pelas conselheiras no espaço socioeducativo tem sido fundamental para a formação cultural das adolescentes. Contudo, acreditam as conselheiras/mediadoras que as experiências de leituras proporcionas a elas váo além do desempenho linguístico, porquanto há fortes evidências de transformação interior das adolescentes.

Nesse sentido, Petit (2009) afirma que "quando a leitura trabalha realmente o leitor, ele pode ser transformado por ela e, nas entrelinhas, encontrar sua fantasia inventiva, se deixar levar pela imaginaçáo, e pensar" (PETIT, 2009, p. 185), evidenciando o caráter formador e transformador da leitura.

As conselheiras/mediadoras nos oportunizaram alguns relatos de experiências de transformação de uma das socioeducandas, que, embora já tenha conquistado sua liberdade, tem entrado em contato com as conselheiras/mediadoras para dizer que pretende realizar a prova da Eja, estando apenas aguardando o resultado da prova do processo seletivo do Instituto Federal de Mato Grosso. Diz, ainda, a conselheira: "essa menina, pra gente, foi bem emblemática, pois ela chegou aqui bem crua, bem acuada. Aí ela foi tomando bastante gosto pela leitura, e sempre vinha aqui e contava emocionada as histórias dos livros lidos por ela".

Segundo os relatos das conselheiras/mediadoras, há, no espaço do CASE/ MT, por volta de 200 obras literárias, e nos revelaram que, como estratégia para despertar o gosto pela leitura/literatura, indicam, de início, principalmente para as socioeducandas que ainda não tiveram nenhum contato com obras literárias, a obra "Tosco", de Gilberto Dari Mattje, publicada em 2009 pela editora Alvorada, pelo fato da obra se identificar com o contexto das adolescentes/ socioeducandas.

De forte caráter educativo, a história de "Tosco", escrita pelo psicólogo e professor Gilberto Dari Mattje, e que foi construída a partir das diversas histórias que a sociedade está acostumada a ouvir e conhecer, desmistifica a origem da violência, bem como proporciona ao leitor uma reflexão sobre as possibilidades de escolha e a importância em assumir as consequências pelas opçôes (EDITORA ALVORADA, 2011, p. 3) ${ }^{6}$.

6 Ver: http://toscoemacao.blogspot.com/2011/08/ 
Evidenciam ainda as conselheiras/mediadoras que as experiências de leitura das adolescentes com a obra Tosco têm proporcionado a elas momentos de "retornos a si", porquanto revelam algumas socioeducandas: "a história do livro Tosco é como se fosse a minha própria história de vida". As conselheiras/mediadoras observaram, ainda, que a leitura da obra leva as socioeducandas a reexaminarem suas próprias atitudes, assim como tem sido o ponto de partida para novas leituras, por se tratar de uma experiência positiva com a prática leitora.

Grande parte das histórias apresentadas na obra em comento advém de situaçôes vivenciadas pelas adolescentes socioeducandas. A história espelha um personagem violento, havendo ainda personagens na história que são internos ou excluídos do convívio social, o que, segundo as conselheiras/ mediadoras, torna-se atrativa a leitura. Dessa forma, ainda segundo as conselheiras/mediadoras, a identificaçáo com o texto provoca o encontro consigo mesmo.

As experiências de leituras das adolescentes com a obra Tosco vêm ao encontro do pensamento do Jouve (2013), o qual nos diz que toda leitura tem uma parte constitutiva de subjetividade, o que evidencia os aspectos da reapropriação parcial do texto pelo leitor. "Com efeito, cada um projeta um pouco de si na sua leitura. Por isso, a relação com a obra não significa sair de si, mas, também, retornar a si”. (JOUVE, 2013, p.53).

Outra obra intermediada com frequência pelas conselheiras/mediadoras e que tem se tornado um dos livros mais lidos no espaço socioeducativo é Um sonho no caroço do abacate (2014), de Moacyr Scliar, bem como as obras do autor Pedro Bandeira, que sempre provocaram uma disputa pra ler, registrando-se que as adolescentes liam a mesma obra por mais de uma vez e ainda nos perguntavam se havia outras obras do autor Pedro Bandeira.

As mediadoras/conselheiras procuram deixar as adolescentes livres para escolher suas leituras, até porque "aqui dentro da unidade esse é um dos poucos momentos que elas podem escolher o que querem”. Contudo, as adolescentes sempre solicitam orientaçóes sobre o que devem ler.

Assim, as mediadoras indicam, apontam e sugerem obras de vários gêneros, a exemplo dos clássicos "Gabriela Cravo e Canela", de Jorge Amado; "As Pupilas do Senhor Reitor", de Júlio Dinis; "O Guarany”, de José de Alencar; "Dom Casmurro", de Machado de Assis; "Dona Casmurra e seu Tigrão", de Jaf Ivan, além de algumas obras de Guimarães Rosa e Érico Veríssimo, não faltando best sellers, como a obra Crepúsculo, escrita pela americana Stephenie Meyer, bem como outras obras pertencentes à biblioteca do CASE/MT. 
No entanto, as experiências de leituras das adolescentes com alguns clássicos não são muito exultantes, vez que o gênero apresenta uma linguagem distante e incompreensível para elas, dado que a grande maioria das adolescentes em medidas socioeducativas, desde sua infância, não teve contato com a cultura letrada.

Entretanto, textos com uma linguagem mais próxima da realidade cognitiva e social das adolescentes, as têm atraído com mais facilidade, porquanto sentem-se capazes de entender sem dificuldades, já que se inserem em um campo conhecido, a exemplo da obra "Dona Casmurra e seu Tigrão" (2008), de Jaf Ivan. A adaptação do cânone é constituída por uma linguagem próxima, portanto, mais acessível às adolescentes. Dessa forma, a obra tem provocado sentidos para algumas adolescentes leitoras.

De acordo com as mediadoras/conselheiras, as adolescentes também tiveram boas experiências de leituras com obras como "A Viagem de Parvana: Mais uma História de Garotas Afegã “ (2012), de Deborah Ellis, e "O Diário de Anne Frank" (2017), de Anne Frank, visto que os enredos das tramas apontam contextos de adolescentes em conflitos diversos, tais como pobreza, guerra, solidão, abandono, confinamento, coragem e persistência, bem como contextos culturais e histórias diferentes do universo vivencial das adolescentes.

Segundo os relatos das conselheiras/mediadoras, na devolução desses livros as adolescentes/socioeducandas, de um modo geral, mostraramse deslumbradas por conhecer universos tão diferentes. Segundo Jo e Máh (conselheiras/mediadoras) as socioeducandas, admiradas com os enredos das tramas, assim se expressaram: "nunca tinha ouvido falar disso, meu Deus!”.

As mediadoras/conselheiras contam ainda que há uma procura espontânea, por parte das adolescentes/socioeducandas, pela leitura da bíblia e textos religiosos, além de livros de autoajuda. No entanto, analisam que algumas adolescentes buscam ter experiências literárias com bíblia e de livros religiosos para demostrar mudanças comportamentais e espirituais.

As adolescentes/socioeducandas, quando chegam ao espaço socioeducativo, apresentam um baixo nível de letramento, não gostam de estudar, sendo que muitas relatam aversão a frequentar os espaços escolares. Relatam Jo e Máh que "a maioria delas chega no CASE/MT sem qualquer experiência com a leitura literária, tampouco com outras leituras, demonstrando um baixo capital cultural e de letramento. Todavia, é realizada uma mediação individual para despertar o prazer de ler, a curiosidade e 
o desejo de ler de forma espontânea, inclusive, de textos difíceis para a realidade das adolescentes.

Daí a estratégia de indicar a obra "Tosco", de Gilberto Dari Mattje, posto que, após essa leitura, as adolescentes sempre solicitam uma próxima. Algumas ainda dizem: "será que o próximo também vai falar de mim?"

Durante uma das entrevistas realizadas no CASE/MT, uma das mediadoras nos relatou sobre as experiências de leitura da socioeducanda "Tai" grande parte dos livros disponibilizados na biblioteca do CASE/MT, entre os quais, praticamente, todas as séries "Crepúsculo", de Stephenie Meyer.

A socioeducanda, ao chegar no CASE/MT para o cumprimento da medida socioeducativa, revelou-se extremamente problemática e agressiva.

Contudo, as intensas leituras realizadas pela socioeducanda "Tai" constituíam um meio para acalmá-la. Segundo uma das conselheiras/ mediadoras, a jovem, no início da rotina de leitura, ao cometer determinado mal feito, dizia: dona Máh: "aprontei, sim! mas, me dá um livro que eu vou para o quarto e fico tranquila". Segundo a conselheira mediadora, foi observado que, realmente, a socioeducanda "Tai" devorava os livros e já evidenciava um bom nível de compreensão leitora.

Todavia, mesmo as adolescentes/socioeducandas que não dominam a compreensão da linguagem escrita não rejeitam a leitura/literatura, aproximando-se, entretanto, de textos mais fáceis e próximos de suas realidades. Para tanto, é necessário atrair as adolescentes/socioeducandas com os livros estimulantes e adequados às suas preferências literárias.

Dessa forma, observa Petit (2009), o ato de ler permite, às vezes, decifrarmos a nossa própria experiência:

Os escritores nos ajudam a nomear os estados pelos quais passamos, a distingui-los, a acalmá-los, a conhecêlos melhor, a compartilhá-los. Graças a suas histórias, escrevemos a nossa, por entre as linhas. E porque tocam o mais profundo da experiência humana - a perda, o amor, o desespero da separação, a busca de sentido - não há razão para que os escritores não toquem cada um de nós. E é exatamente nesse ponto que jovens leitores vindos de meios desfavorecidos podem, muitas vezes, se encontrar com eles. (PETIT, 2009, p.38-39).

7 Embora, possuíssemos os termos de Consentimento Livre e Esclarecido, utilizamos nomes fictícios nas entrevistadas. 


\section{Considerações finais}

Embora as conselheiras/mediadoras não possuam formação e competência profissionais especificas acerca do ensino da literatura, o trabalho realizado por elas abriu espaço de suas possibilidades ao ampliar o universo de linguagem e cultural, bem como tem contribuído para a formação, hábito e gosto pela leitura/literatura das adolescentes engajadas com a atividade leitora no contexto socioeducativo. Assim, as intervençóes realizadas pelas mediadoras têm favorecido a formação literária, no espaço e no tempo socioeducativo, com o intuito provocar a continuidade do letramento literário fora do espaço socioeducativo.

$\mathrm{O}$ projeto de leitura, embora não formalizado e distante das práticas pedagógicas sistematizadas no socioeducativo, ganhou dimensóes inesperadas pelas conselheiras/mediadoras, vez que o trabalho começou a gerar frutos, pois, de forma espontânea, as adolescentes têm "multiplicado" o gosto e o hábito pela leitura, realizando, inclusive, trocas de livros entre si e, ainda, compartilhando suas experiências com histórias lidas por elas. Foi dessa forma, segundo as 'mediadoras', que os livros passaram a circular de foram inesperada na unidade socioeducativo.

Ao ouvir sobre as experiências de leitura das jovens/adolescentes, por meio dos relatos das conselheiras/mediadoras, vimos que a leitura, de um modo geral, tem contribuído para a transformação das jovens/adolescentes. Aliás, segundo Petit (2009, p. 99-100), a leitura pode contribuir para "a reorganização de universos simbólicos linguísticos em diferentes campos”.

Por conseguinte, a leitura contribui para transformaçóes na representação de si mesmo, na maneira de se pensar, se dizer, se situar nas relaçóes familiares, bem como na transformaçáo nas formas de sociabilidade e solidariedade, podendo, ainda, proporcionar caminhos para que os jovens se tornem um pouco mais atores de suas vidas, donos de seus destinos e não somente objetos do discurso dos outros, assim como a se diferenciar dos rótulos estigmatizastes que os excluem, além de transformaçóes na trajetória escolar e profissional.

Evidenciam os estudos que a leitura é "uma arte que se transmite mais do que se ensina”. Contudo, Petit (2009, p.148) destaca que, "embora a leitura fosse em grande parte uma questão de família, também é influenciada por um contexto mais amplo, um ambiente que convida ou desestimula a aproximarse dos livros".

Vimos então, que o trabalho realizado pelas conselheiras/mediadoras, movidas pelo amor à leitura e à literatura e, ainda, por um olhar diferenciado pelas adolescentes em cumprimento de medidas socioeducativas, construiu um 
ambiente de aproximação dos livros, oportunizando a cada jovem/adolescente engajada nas práticas de leitura oportunidades de encontros singulares com os textos que podem lhes oferecer algo em particular.

No entanto, observamos que o trabalho de mediação da leitura realizado pelas conselheiras nas dependências do CASE/MT deveria ser compartilhado com a escola, visto que a leitura é uma atividade dinâmica, e a compreensão de um texto envolve inúmeras habilidades que ultrapassam a capacidade de decodificação da língua escrita, exigindo, por assim dizer, procedimentos sistemáticos adotados pela escola.

\section{Referências}

AGUIAR, Vera Teixeira de. O saldo da leitura. In: DALVI, Maria Amélia et al. (org.). Leitura de literatura na escola: São Paulo: Ed. Parábola, 2013.

BRASIL, Estatuto da Criança e do Adolescente. Disponível em: http://www. planalto.gov.br/ccivil_03/leis/18069.htm. Acesso em: 5 de agosto de 2018.

BRASIL. Constituição da República Federativa do Brasil de 1988: Disponível em: http://www.planalto.gov.br/ccivil_03/constituicao/ constituicao.htm. Acesso em: 5 de agosto 2018.

BRASIL. Presidência da República. Secretaria de Direitos Humanos (SDH). Plano Nacional de Atendimento Socioeducativo: Diretrizes e eixos operativos para o SINASE. Brasília: Secretaria de Direitos Humanos da Presidência da República, 2013.

BRASIL. Secretaria Especial dos Direitos Humanos: parâmetros para formação do socioeducador. uma proposta inicial para reflexão e debate / Coordenação técnica Antônio Carlos Gomes da Costa. Brasília, 2006.

BRASIL. Sistema Nacional de Atendimento Socioeducativo SINASE. Disponível em http://www.conselhodacrianca.al.gov.br/sala-de-imprensa/ publicacoes/sinase.pdf. Acesso em: 5 de agosto 2018.

BRASIL. Socioeducaçáo: Estrutura e Funcionamento da Comunidade Educativa. Coordenação técnica Antônio Carlos Gomes da Costa. - Brasília: Secretaria Especial dos Direitos Humanos, 2006.

CHARTIER, Roger. Práticas da leitura. Tradução: Cristiane Nascimento. São Paulo: Estação Liberdade, 1996, p. 231-253

CHARTIER, Roger. Texto, impressão, leituras. In: HUNT, Lynn. A nova história cultural. Tradução: Jefferson Luiz Camargo. São Paulo: Martins Fontes, 1992. 
DAUSTER.Tânia. Jogos de inclusão e exclusão sociais: sobre leitores e escritores urbanos no final do século XX no Rio de Janeiro. In: YUNES, E. A experiência da leitura. São Paulo: Ed. Loyola, 2003.

DEBORA, Ellis. A Viagem de Parvana: mais histórias de uma garota afegã. 2 ed. São Paulo: Ática. 2012.

EDITORA ALVORADA: Tosco em açáo. Disponível em: http:// toscoemacao.blogspot.com/2011/08/. Acesso em: 5 de agosto 2018.

FOUCAMBERT, Jean. A leitura em questáo. Porto Alegre: Artes Médicas, 1994.

FRANK. Ane. O diário de Ane Frank. Tradução: Elia Ferreira Edel: São Paulo, Ed. Le Books. 2017.

FREIRE, Paulo. A importância do ato de ler em três artigos que se completam. Sáo Paulo, Cortez Ed., 2000.

GOLDIN, Daniel. Os dias e os livros: divagaçóes sobre a hospitalidade da leitura. Tradução: Carmem Cacciacarro. São Paulo: Ed. Pulo do Gato, 2012.

JAF. Ivan. Dona Casmurra e Seu Tigrão. São Paulo, Ed. Ática, 2008

JOUVE, Vicente. A leitura como retorno a si: sobre o interesse pedagógico das leituras subjetivas. In: ROUXEL, Annie; LANGLADE, Gérard; REZENDE, Neide Luzia de (org.). In: Leitura subjetiva e ensino de literatura. São Paulo: Alameda. 2013. p. 53-66.

LARROSA, J. Pedagogia profana: danças, piruetas e mascaradas. 4. ed. Belo Horizonte: Autêntica, 2006.

MATTJE. Gilberto. Tosco. São Paulo, Ed. Alvorada, 2009.

PETIT, Michèle. A arte de ler ou como resistir à diversidade. Tradução: Artur Bueno e Camila Boldrini Nascimento. São Paulo: Ed. 34, 2010.

PETIT, Michèle. Os jovens e a leitura: uma nova perspectiva. Tradução: Celina Olga de Souza. São Paulo: Ed.34, 2009.

REZENDE, Neide Luzia de. O ensino de literatura e a leitura literária. In: Leitura de literatura na escola. Maria Amélia Dalvi, Neide Luzia Rezende, Rita Jover-Faleiros. (orgs.). São Paulo, Ed. Parábola. 2013.

SCLIAR, Moacir. Um sonho no caroço do abacate. São Paulo. Ed. Global, 2014. 


\section{JOGO "HOSPITAL MIRIM": ANALOGIAS ENTRE SAÚDE E EDUCAÇÃO NO ENFRENTAMENTO À PROCEDIMENTO INVASIVO COM CRIANÇA}

Kamilla Furtado Regatieri

Tatiane Lebre Dias

\section{Introdução}

A infância é uma etapa da vida fundamental para o desenvolvimento humano. Fase marcada pelas atividades físicas intensas e descobertas, nas quais os possibilitam explorar e conhecer o ambiente a sua volta. Para aproveitar tal etapa de uma forma mais positiva e sem muitos prejuízos é necessário gozar de boa saúde. Porém, no decorrer do desenvolvimento, grande parte das crianças passam por períodos de doenças, na maioria das vezes acompanhado pela hospitalização para obter diagnóstico, tratamento, cura, intervençôes, entre outros (CASTRO; PICCININI, 2002).

Em decorrência da exposição frequente a procedimentos médicos invasivos e/ou aversivos e a possibilidade de desencadear reaçóes de estresse torna-se evidente a necessidade do desenvolvimento de métodos de avaliação e de estratégias de intervenção que contribuam para a redução do sofrimento da criança, prevenindo o agravamento das reaçóes de dor e ansiedade em procedimentos subsequentes (MANNE et al. 1994).

No uso da maior parte dessas técnicas de intervenção, existe a característica lúdica, em que o brinquedo tem sua função de diversão estendida à possibilidade de elaboração de sentimentos e aprendizagem de novos comportamentos. No caso, o componente lúdico do procedimento teria função educativa e terapêutica (MOTTA; ENUMO, 2010).

Por procedimento invasivo entende-se como técnicas operativas diagnósticas que envolvem uso de instrumentos que penetram os tecidos ou invadem algum orifício do corpo. A intensidade da dor provocada nesses procedimentos invasivos pode variar de moderada a severa, podendo aumentar à medida que elas se repetem no decorrer do tempo (LEMOS, 2010).

A hospitalização de uma criança gera diversas consequências para a família e a própria criança, como presença de estresse materno (CARNIER et al., 2012), 
impacto na rotina familiar (RUMOR; BOEHS, 2013) e os próprios procedimento invasivos presentes na maioria das internaçóes ou procedimentos ambulatoriais. Desse modo, o uso do jogo "Hospital Mirim" que se baseia em etapas do procedimento invasivo de punção venosa, sendo uma ferramenta disponível para acesso gratuito e que ainda não foi testada em nenhum estudo, além de ser de fácil manejo e atual, poderá contribuir futuramente para o enfrentamento de crianças que passam pela coleta de sangue.

$\mathrm{Na}$ maioria das vezes, as crianças hospitalizadas passam por diversos procedimentos dolorosos como citado acima, sem compreender, muitas vezes, como esses serão executados, por qual razão e finalidade precisam vivenciá-los, o que pode desencadear em diversas alteraçóes no comportamento, no humor e, muitas vezes, na auto-imagem da criança (PETTENGILL; CHERON, 2011).

O procedimento invasivo de punção venosa é um dos mais realizados com as crianças hospitalizadas. Este procedimento pode ser ameaçador ao bemestar físico e psicológico em todas as idades, porém, é particularmente mais difícil para crianças e adolescentes, consequência dos limitados mecanismos de estratégias de enfrentamento (coping) eficaz podendo ativar reaçóes de stress e ansiedade (SKINNER et al., 2011).

Também nesta etapa da vida, a estrutura cognitiva e psicoemocional da criança está em desenvolvimento, e os recursos para enfrentar situaçóes dolorosas são mais limitados, além da incapacidade muitas vezes para entender aquela realidade (RIBEIRO et al., 2002).

Entre uma das estratégias não farmacológicas que vem sido utilizadas para diminuição da ansiedade, medo e dor perante o procedimento invasivo estáo o uso do brinquedo terapêutico. $\mathrm{O}$ brinquedo terapêutico, utilizado para explanação a respeito dos procedimentos médicos a serem realizados com a criança possibilita a ela relatar seus medos e ansiedade (GIACOMELLO; MELO, 2011).

O brinquedo torna o processo de hospitalização menos traumático, consequentemente os efeitos negativos são minimizados, contribuindo assim para a humanização da assistência à criança, uma vez que ajuda positivamente na realização dos procedimentos clínicos. $\mathrm{O}$ brinquedo além de permitir a recreação, apresenta outra importante função que é a dramatização, isso possibilita alívio do indivíduo, assumindo função curativa (FERRARI; ALENCAR; VIANA, 2012).

$\mathrm{O}$ brinquedo terapêutico (BT) pode ser definido como uma brincadeira estruturada e tem como objetivo preparar a criança para procedimentos a que ela será submetida, auxiliando, assim, na sua compreensão e cooperação com a equipe de saúde (GIACOMELLO; MELO, 2011). 
Com o grande interesse das crianças por dispositivos eletrônicos, o jogo Hospital Mirim propóe o desenvolvimento de um Brinquedo Terapêutico Digital Interativo (BTDI). A concepção de BTDI está embasada em técnicas e metodologias de Realidade Virtual (RV) e Jogos. Essas áreas têm despertado grande interesse no campo da saúde, pois ampliam as possibilidades de simulaçóes de situaçóes reais e procedimentos médicos, possibilitando manipular e analisar diretamente o objeto de estudo.

Observa-se também na literatura que sistemas de RV têm feito uso de estratégias de interação baseadas em jogos em diferentes contextos, indo além do escopo diversão e entretenimento (serious games) (COSTA et al., 2015). Os serious game têm como propósito combinar aspectos sérios de aprendizado, comunicaçáo ou troca de informaçóes, com a experiência divertida que um jogo digital pode oferecer (ALVAREZ; DJAOUTI; JESSEL, 2011).

Para Parisod et al., (2014) intervençóes da área da saúde através de games traz a vantagem de facilitar a adesão dos pacientes, especialmente as crianças, ao tratamento e de as manter motivadas por mais tempo. A tecnologia traz inúmeros benefícios ao processo educativo. A combinação de estímulos e elementos artísticos variados (animação, música, desenho e histórias) favorecem o processo de aprendizagem, podendo abordar características lúdicas a conteúdos específicos.

O que difere o serious games dos demais tipos de jogos é o foco em resultados específicos de aprendizagem. Possuem um propósito específico e oferecem oportunidades de aprendizagem e mudanças de comportamento (MACHADO et al., 2011). O serious games tem como propósito combinar aspectos sérios de aprendizado, comunicação, ou troca de informaçóes com a experiência divertida que um jogo pode oferecer (ALVAREZ; DJAOUTI, 2011).

Com a experiência cada vez mais precoce no uso da tecnologia, e na era do videogame, abordagens mais lúdicas e eficazes aplicadas à área da saúde são ferramentas que agregam valor de forma impactante na saúde coletiva. No âmbito educacional, jogos digitais têm possibilitado às crianças formas lúdicas de aprendizado de conteúdos (tradicionalmente, pouco atrativos), ao associarem em fantasias, desafios e interaçóes ao processo de geração de conhecimento básico. Estes conteúdos têm sido absorvidos tanto no contexto de uma experiência familiar, social, sendo motivacional para uma geração que cresce interagindo com jogos eletrônicos (ALVES; BATAIOLLA, 2017).

O jogo "Hospital Mirim" se passa em um quarto de hospital, como sugerido em pesquisa no ambiente hospitalar pelos profissionais da saúde, a fim de familiarizar a criança no ambiente em que ela está inserida. $\mathrm{O}$ ambiente 
apresenta elementos que o caracterizam como um quarto infantil de hospital, incluindo leito, acessórios hospitalares, brinquedos e decoração característica.

$\mathrm{O}$ jogador por meio de seu avatar (personagem) pode explorar o mundo virtual com liberdade de movimentação, podendo caminhar pelo quarto e interagir com os bonecos tridimensionais. Procurando estimular a imersão do jogo, o menu principal propóe elementos que caracterizam a tridimensionalidade do ambiente, com textos interativos, câmera dinâmica e os diferentes avatares para escolha do jogador.

A criança escolherá o personagem que será o enfermeiro, tendo diversos bonecos de várias etnias, gênero, cores, devido à diversidade das crianças hospitalizadas. Após a escolha do enfermeiro, ela irá escolher o personagem (urso, boneca, robô) que irá passar pela coleta de sangue.

Figura 1 - Seleção do paciente virtual.

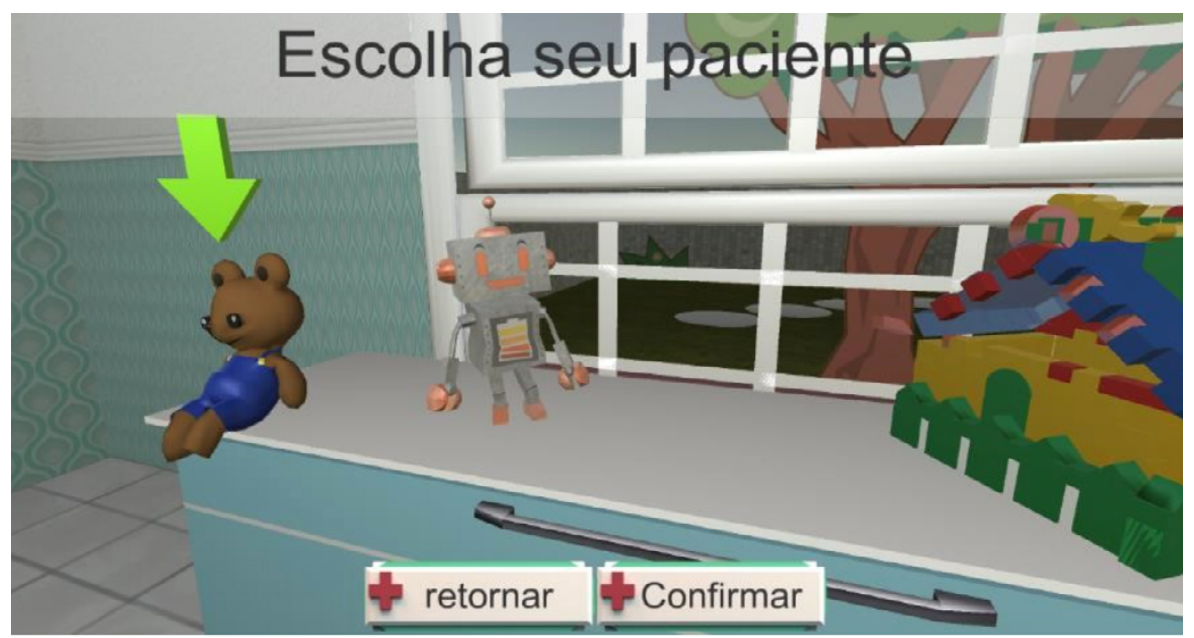

Fonte: Lemos; Nunes, (2016)1.

Após a seleção do paciente, o avatar pode caminhar pelo cenário livremente, até o leito hospitalar. Ao encontrar o leito, o paciente virtual aguardará o profissional de saúde e uma janela será mostrada perguntando ao jogador se deseja "Iniciar procedimento?"

No caso de o jogador selecionar "Sim", uma nova janela será aberta para escolha do tipo de procedimento. Nesta versão do serious games estáo disponíveis os procedimentos de coleta de sangue e aplicação de medicamento.

1 Disponível em: https://play.google.com/store/apps/details?id=com.projeto.HospitalMirimRemastered 
Após a escolha, o jogador será direcionado para a cena seguinte, referente ao procedimento selecionado.

\section{Figura 2 - Interface de início do procedimento.}

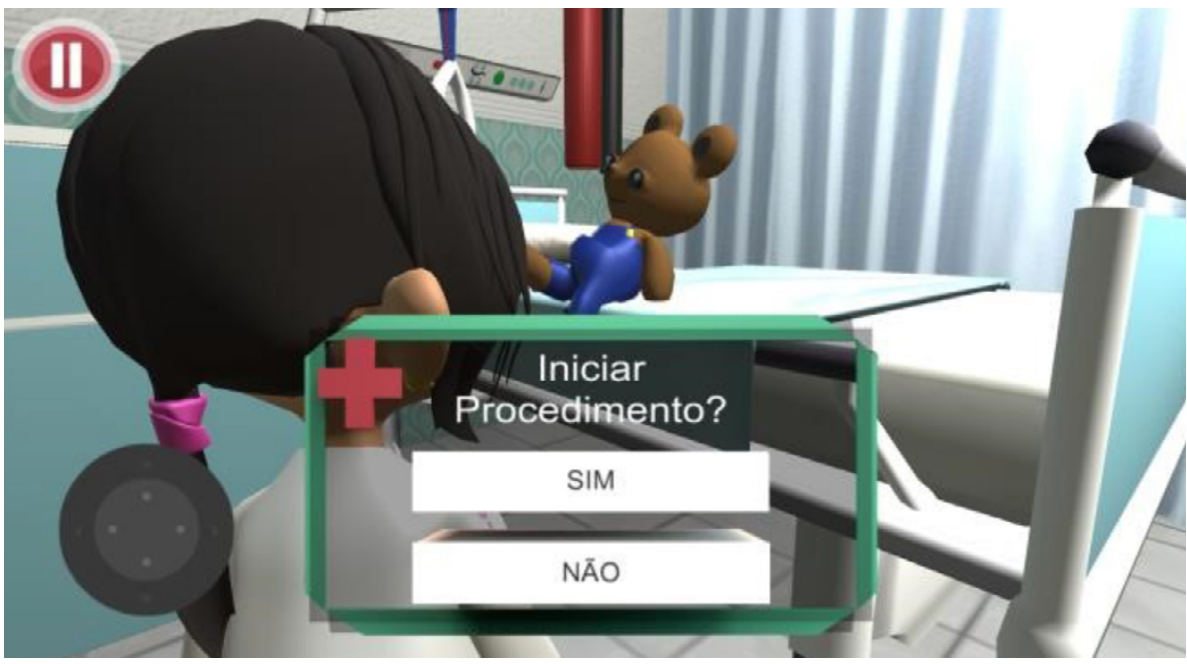

Fonte: Lemos; Nunes, (2016)2.

A cena seguinte se refere ao procedimento de punçáo venosa para coleta de sangue, acompanhada de diálogos de orientação ao jogador, a fim de compreender a necessidade de realização do procedimento. Diálogos adicionais foram inseridos a fim de auxiliar na condução das etapas do procedimento. Tal procedimento pode ser avaliado com uma função educativa, pois ensinará através de diálogos qual material utilizar no procedimento e a função deles. As etapas são descritas na seguinte ordem:

- Aplicação do garrote no paciente

- Aplicação do algodão no álcool para esterilização

- Aplicação do algodão com álcool no paciente

- Seleção da seringa para retirada de sangue

- Remoção do garrote

- Remoção da seringa

- Aplicação de curativo

2 Disponível em: https://play.google.com/store/apps/details?id=com.projeto.HospitalMirimRemastered 


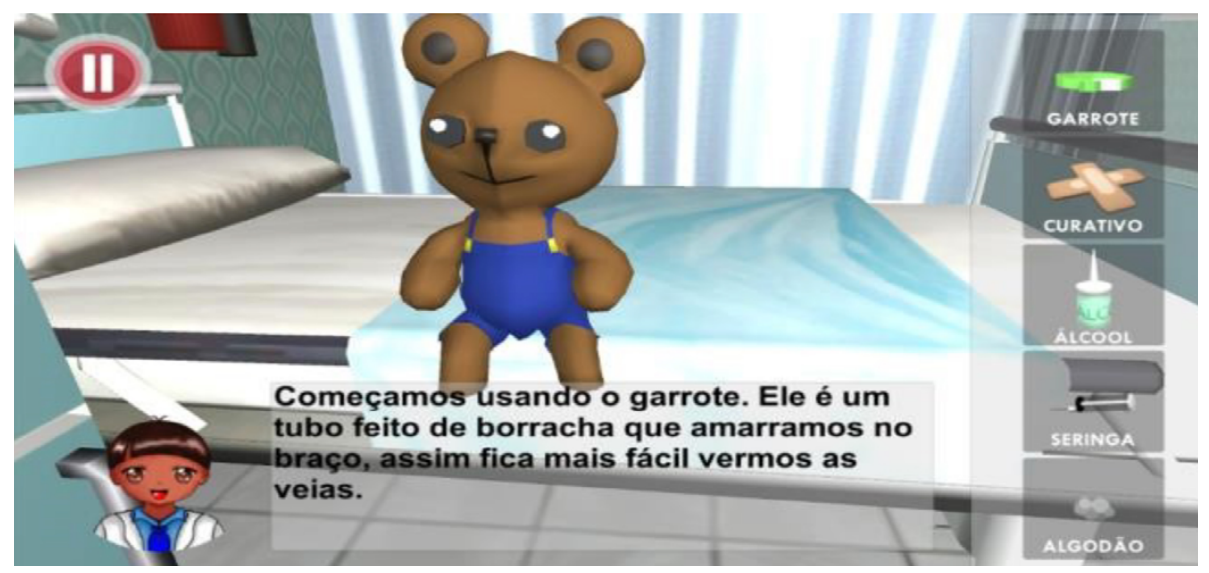

Fonte: Nunes (2016) 3.

Os diálogos do serious game "Hospital Mirim” foram elaborados com base no roteiro do jogo, definidos juntamente com a equipe multidisciplinar do hospital parceiro do projeto, considerando a faixa etária das crianças de 5 a 12 anos. Os diálogos foram elaborados em uma linguagem informal, simples e objetiva, buscando facilitar o entendimento do público alvo. O roteiro do jogo dividiu os diálogos dos personagens em três tipos (LEMOS; NUNES, 2016).

- Diálogos de orientação - são responsáveis por apresentar esclarecimentos sobre o tipo do procedimento e o que poderá ocorrer com o paciente. A jogabilidade não é explorada nessa etapa, apenas apresenta-se de forma lúdica o procedimento a ser executado.

- Diálogos de condução do procedimento - são responsáveis por orientar as etapas a serem seguidas na execução do procedimento. São etapas sequenciais, sem possibilidade de retorno, haja vista que se trata de um jogo no qual é atribuído ao jogador uma pontuaçáo em cada etapa, sendo cada etapa vinculada a um diálogo explicativo.

- Diálogos de erro - apresentam frases de erro, caso a etapa do procedimento tenha sido executada de forma errada. Os diálogos de erros apresentam frases para estimular o jogador a tentar novamente.

3 Disponível em: https://play.google.com/store/apps/details?id=com.projeto.HospitalMirimRemastered 
A partir do exposto o presente estudo teve por objetivo investigar o uso do serious game Hospital Mirim como uma estratégia de enfrentamento lúdica e de aprendizagem para crianças submetidas ao procedimento invasivo de coleta de sangue.

\section{Participantes do estudo}

Trata-se de um estudo experimental, no qual foi realizado intervenção com o jogoserious game Hospital Mirim, em que participaram 20 criançasque passaram pela coleta de sangue no laboratório de análises clínicas do Hospital Universitário, com idades entre seis a dez anos e seus respectivos acompanhantes. O critério de escolha das crianças foi feito de forma aleatória, sendo a primeira do grupo experimental (passaria pelo jogo antes da sua coleta de sangue), a segunda do controle (passaria pelo jogo após sua coleta de sangue).

Utilizaram-se os seguintes critérios de inclusão: criança na faixa etária que iria passar pela coleta de sangue, autorizaçáo do acompanhante da criança, sendo pais ou responsáveis que estavam acompanhando a criança no momento da coleta e da própria criança através do Termo de Assentimento. Para a participação de ambos, foi apresentado o Termo de Consentimento aos responsáveis autorizando a participação da criança. $\mathrm{O}$ projeto foi aprovado pelo Comitê de Ética da Instituiçáo com o parecer número 032018A.

O estudo foi realizado no setor laboratório de coleta de sangue dentro do Hospital Universitário Júlio Muller, localizado na regiáo central de Cuiabá-MT. Nesse setor, o HU dispóe de cadeiras para coletas, não tendo a separação de adultos com o público infantil. Diariamente passam crianças pelo laboratório para a coleta de sangue, após entrarem os profissionais responsáveis pela coleta atendem de acordo com a chegada do paciente ao local. Não há profissional específico para coletar sangue das crianças. Cada um tem um perfil de trabalho, alguns conversam, distraem as crianças, outros já realizam o procedimento de forma mais mecânica.

Como tal procedimento é realizado no mesmo local para todos os tipos de pacientes, em alguns momentos antes da coleta havia choro e resistência de crianças menores, no qual o participante da pesquisa o percebia antes mesmo de entrar para a sala e realizar a sua coleta de sangue. Não há um número exato de crianças que passam pelo laboratório diariamente, sendo muito sazonal, porém há um grande número de atendimentos infantis durante o mês. A presença do acompanhante durante a realização deste procedimento é permitida. 


\section{Percurso da pesquisa: materiais, instrumentos utilizados e a coleta de dados}

Para a realização do estudo foram utilizados os seguintes instrumentos:

- Entrevista semi-estruturada com os pais ou responsáveis, com o objetivo de avaliar a condição sócio-demográfica da criança, verificar se era a primeira vez dela no procedimento invasivo, como o pai ou responsável percebe o comportamento da criança nestes procedimentos;

- Entrevista semi-estruturada com a criança antes e após procedimento de coleta de sangue com o objetivo de avaliar a percepçáo da criança sobre o procedimento invasivo de coleta de sangue, verificar como a criança avaliou o jogo Hospital Mirim;

- Jogo Hospital Mirim;

- Escala de comportamento- Escala de Observação de Procedimento Invasivo (OSDB, do inglês: Observation Scale of Distress Behavior é composta por 11 categorias morfológicas de comportamentos que indicam o sofrimento vivenciado pela criança durante a execuçáo de procedimentos invasivos (CHARRY; SILVA, 2010);

- Escala de dor-Faces PainScale-Revised (FVS-R): a partir de três anos de idade, com tradução e adaptação para o português brasileiro por Morete et al. (2014). Tal escala compóe-se com figuras que apresentam várias intensidades da dor, para verificar como a criança percebe a dor antes e depois do procedimento invasivo. As caras mostram como alguma coisa pode doer. Esta cara [aponte para a face mais à esquerda] não mostra dor. As caras mostram cada vez mais dor [aponte para cada uma das faces da esquerda para a direita] até chegar a esta [aponte para a face mais à direita] que mostra muita dor. Aponte a cara que mostra como está sentindo (CHARRY; SILVA, 2010).

$\mathrm{Na}$ fila para a realização da ficha cadastral, a pesquisadora identificava a criança, apresentava a pesquisa para os responsáveis e para a própria criança e após o consentimento iniciava a coleta de dados na fila de espera. Primeiramente realizava a entrevista com o responsável e ele mesmo respondia a escala de comportamento de acordo com a sua percepçáo sobre a criança. Logo após iniciava-se a entrevista com a criança. 
Depois de preenchida a ficha cadastral, na sala de espera, a pesquisadora aplicava o jogo Hospital Mirim na criança que fazia parte do grupo experimental. No momento da coleta, junto ao responsável da criança, permanecia presente aplicando a escala de observação.

Logo após o procedimento acompanhava a criança novamente a sala de espera, finalizando a coleta de dados com a entrevista semi-estruturada pós-procedimento. Além de entrevistada, à criança que fazia parte do grupo controle era ofertada a possibilidade de jogar oserious game Hospital Mirim.

\section{Análise dos dados}

Os dados coletados neste estudo foram mensurados qualitativamente e quantitativamente. Em relação a entrevista com os responsáveis, obteve-se a informação que no grupo controle as dez crianças estavam acompanhadas das mães, já no grupo experimental, oito estavam acompanhadas das mães e duas acompanhadas por avós.

Na pergunta relacionada à experiência anterior em tirar sangue, obtevese o seguinte resultado: ambos os grupos apresentaram duas crianças que relatou nunca ter tirado sangue antes. No grupo controle cinco crianças têm irmãos, já no grupo experimental sete das crianças têm irmãos. $\mathrm{Na}$ pergunta referente ao que sentiam antes de realizar o procedimento de coleta de sangue em ambos os grupos, o maior número de respostar estava relacionado ao medo da situação.

Em relação aos comportamentos apresentados pelas crianças durante o procedimento de coleta de sangue, observou-se proximidade na frequência dos comportamentos.

\section{Gráfico 1 - Frequência de comportamentos apresentados pelas crianças durante 0 procedimento de coleta de sangue}

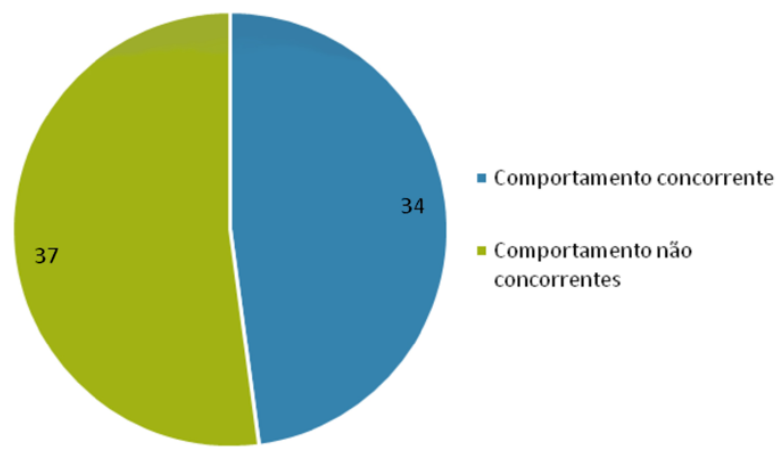

Fonte: As autoras. 
Ao comparar osresultados em relação aos tipos de comportamentos apresentados, sendo eles comportamentos concorrentes (dificultam o procedimento como chorar, bater, gritar) e os comportamentos não concorrentes (facilitam o momento da coleta como dar o braço sem resistir), por grupo observou-se que as crianças apresentaram frequências próximas.

Gráfico 2 - Comportamentos apresentados pelas crianças do grupo experimental e grupo controle $(\mathrm{N}=20)$.

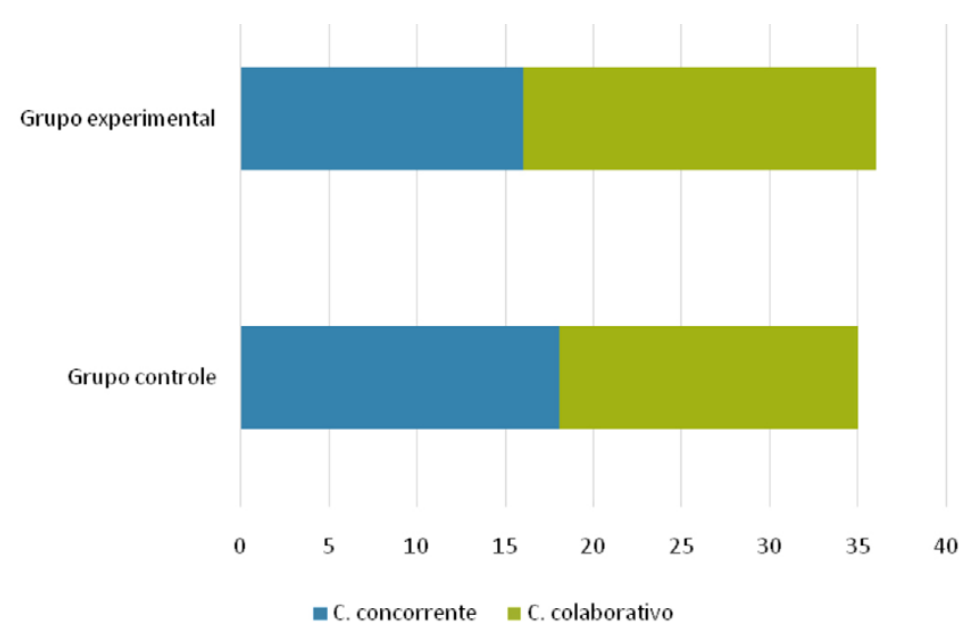

Fonte: As autoras.

O grupo controle apresentou um número um pouco maior de comportamentos concorrentes, ou seja, aqueles que dificultam a ocorrência do procedimento de coleta como, por exemplo: chorar, mexer o braço, gritar. O grupo experimental apresentou um número maior de comportamentos não concorrentes, aqueles que facilitam no procedimento como, por exemplo: dar o braço sem resistência, responder à pergunta do enfermeiro. 


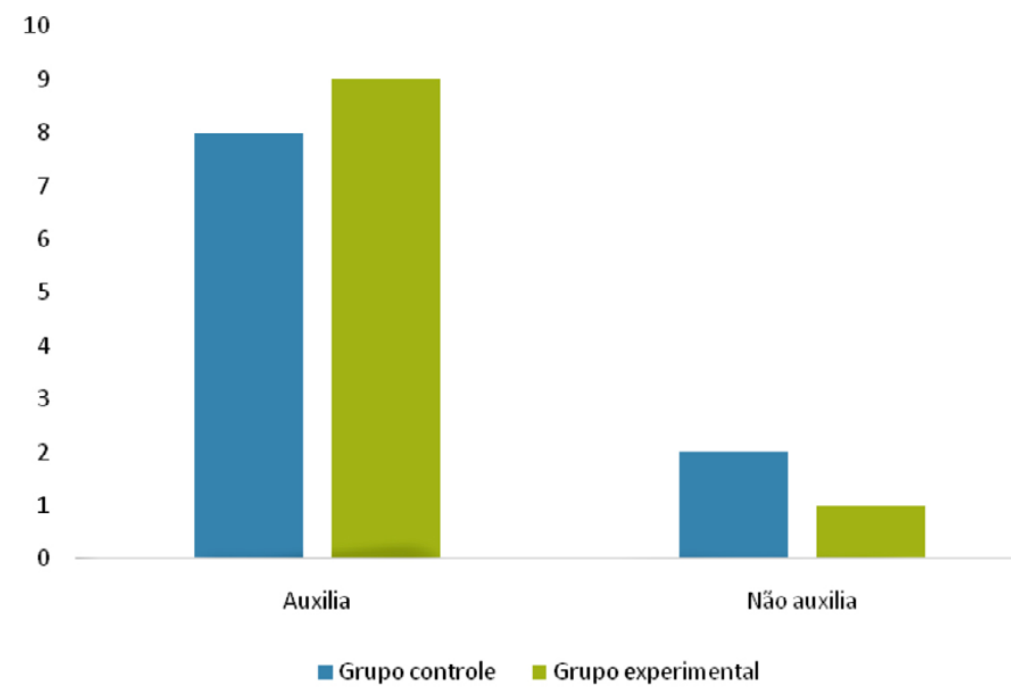

Fonte: As autoras.

Quando questionados sobre a eficácia do jogo se tivessem jogado antes do procedimento $80 \%$ das crianças do grupo controle afirmou que o jogo os auxiliariam. O grupo experimental, quando perguntado se o jogo auxiliou no seu procedimentono procedimento de coleta de sangue, 90\% das crianças responderam que sim, como pode ser observado abaixo.

\section{Considerações finais}

No período atual, o número de utilizadores de jogos digitais corresponde a 179 milhóes de pessoas, o que equivale em torno de $61 \%$ da população mundial, de 110 países ao redor do mundo. Este número cresce a cada ano em toda perspectiva mundial. Os games, ao mesmo tempo em que divertem, podem ser aplicados como instrumentos educativos.

As teorias contemporâneas educacionais eficazes sugerem que a aprendizagem é mais efetiva quando é ativa, experiencial, contextualizada, baseada em problemas e prevê feedback imediato. Neste contexto de aprendizagem, jogos oferecem atividades que têm todas estas características.

Com isso ressalta-se a importância cognitiva destes jogos que desenvolvem habilidades indispensáveis ao processo de aprendizagem como atenção, concentração, criatividade, orientação espacial, trabalho colaborativo, temporalidade. 
O jogo "Hospital Mirim” utilizado nesta pesquisa, pode ser avaliado como um brinquedo terapêutico digital interativo que apresenta função de entretenimento e educativa. Os dados coletados demonstram que a maioria das crianças que participaram da pesquisa avaliaram o jogo como um facilitador para o procedimento invasivo de coleta de sangue.

Considerando o grande número de crianças que adquirem algum tipo de doença durante a infância e a maioria das mesmas passam por uma hospitalização para tratamento, diagnóstico, cura, intervenção entre outros é de extrema importância a utilização de métodos interventivos que facilitem nesse período difícil na vida da criança. Um dos procedimentos invasivos muito recorrentes na hospitalização é a coleta de sangue, tema principal deste trabalho.

Os procedimentos invasivos podem desencadear medo, ansiedade e estresse nos adultos e principalmente nas crianças, pelo fato de náo compreenderem ao certo o que irá acontecer, por não ter desenvolvido mecanismos de enfrentamentos mais adaptativos e por avaliar a situaçáo de tirar sangue como gerador de muita dor.

No desenvolver da pesquisa foi possível perceber que a utilização do jogo Hospital Mirim como estratégia de enfrentamento para procedimento invasivo de coleta de sangue contribuiu para as crianças pesquisadas. A maioria conseguiu avaliar uma função educativa no jogo, dizendo que aprenderam o que aconteceria com eles, a maioria respondeu que o jogo auxiliou a enfrentar o próprio procedimento e no grupo experimental que teve acesso ao jogo antes do procedimento invasivoa percepçáo da dor avaliada no momento do procedimento e no pós-procedimento foi avaliada com uma pontuaçáo menor do que o grupo controle. Assim como mostram algumas pesquisas.

A abordagem educacional baseada em jogos eletrônicos pode ser útil e de boa receptividade, além de integrar características lúdicas a conteúdos específicos, motivando assim o processo de aprendizado das crianças. A ação de estímulos e elementos artísticos variados favorece o processo de aprendizagem e motiva a criança a aderir ao tratamento.

As diferentes formas de aprendizagem que os games promovem e enfatizam a similaridade entre estratégias que as crianças utilizam nos games e os princípios de métodos científicos (sondagem, hipótese, nova sondagem, novo pensamento).

Tais princípios e estratégias também se relacionam as aprendizagens com games e o desenvolvimento de habilidades hipotético-dedutivas, que 
implicam a construção e verificação de hipóteses e deduções durante o jogo segundo o autor, são essenciais para a formação do pensamento científico.

Um dos aprendizados principais nos jogos é atomada de decisóes, e isso implica escolha e prioridades, os "benefícios intelectuais do jogo resultam dessa virtude fundamental, porque aprender como pensar, em última análise, tem a ver com aprender a tomar a decisão certa: pesar a evidência, analisar situaçóes, consultar suas metas a longo prazo e, então, decidir".

O estudo apresenta algumas limitaçóes entre elas o número de participantes, entretanto, nas observaçóes foi possível identificar que fatores como postura do profissional, postura do acompanhante da criança, pega a veia somente uma vez, também influenciam e contribuem no procedimento invasivo das crianças.

Ressalta-se a importância do desenvolvimento de outras pesquisas relacionadas à temática, com o público alvo infantil pode ser extremamente relevante para auxiliar no enfrentamento à procedimentos invasivos, que muitas vezes são causadores de medo, ansiedade e estresse.

\section{Referências}

ALVAREZ, Julian; DJAOUTI, Damien; JESSEL, Jean-Pierre. Origins of Serious Games. Origins of Serious Games. Disponível em: http://www. ludoscience.com/files/ressources/origins_of_serious_games.pdf. Acesso em: 10 de abril 2019.

ALVES, Márcia Maria; BATTAIOLA, André, Luis. Gamificação como estratégia de design para a animação interativa educacional. XVI SBGames - Curitiba - PR - Brazil, novembro, 2017.

CARNIER, Luciana Esgalha; RODRIGUES, Olga Maria Piazentin Rolim; PADOVANI, Flávia Helena Pereira. Stress materno e hospitalização infantil pré-cirúrgica. Estud. psicol. Campinas, v. 29, n. 3, p. 315-325, Sept. 2012. Disponível em: http://www.scielo.br/scielo.php?script=sci_ arttext\&pid=S0103166X2012000300002\&lng=en\&nrm=iso. Acesso em: 03 de abril 2019.

CASTRO, Elisa Kern; PICCININI, Cesar Augusto. Implicaçóes da doença orgânica crônica na infância para as relaçóes familiares: algumas questôes teóricas. Porto Alegre: Universidade do Rio Grande do Sul, 2002. 
CHARRY, Claudia L. E; SILVA, José Aparecido Da. Mensuração da dor rememorada em crianças de escola: diferenças segundo a idade e o gênero. Temas psicol, Ribeirão Preto, v. 18, n. 2, p. 377-384, 2010. Disponível em: http://pepsic.bvsalud.org/scielo.php?script=sci_ arttext\&pid=S1413389X2010000200012\&lng=pt\&nrm=iso. Acesso em: 06 de abril 2019.

CONNOLLY, T. M.; BOYLE, E.; MACARTHUR, E.; HAINEY, T.; BOYLE, J. M. A systematic literature review of empirical evidence on computer games and serious games. Computers \& Education, 59(2):661686, 2012.

COSTA, Tulio, H; PAIVA, Breno, MENEZES, Rinaldo, RAMOS, Lucas; BUBLITZ, Frederico. NuSense: A SensorBased Framework for Ambient Awareness applied in Game Therapy Monitoring. Disponível em: https://pdfs.semanticscholar. org/ 4 e 1 c/f23389896b4e7d 8 b 03 ab 726 a 0 d 0 db 2907 b 23 . $\mathrm{pdf}$ ? _ga=2.199485742.1603074459.15574982331748330387.1557498233. Acesso em: 06 de abril 2019.

FERRARI, Rogério; ALENCAR, Gilmar; BARBOSA, Viero. Análise das produçóes literárias sobre o uso do brinquedo terapêutico nos procedimentos clínicos infantis. Revista Eletrônica Gestão \& Saúde, Vol.03, No. 02, Brasília, 2012.

GIACOMELLO, Karina Jorgino; MELO, Luciana de Lione. Do faz de conta à realidade: compreendendo o brincar de crianças institucionalizadas vítimas de violência por meio do brinquedo terapêutico. Ciência Saúde Coletiva, Rio de Janeiro, v. 16, supl. 1, p. 1571-1580, Abril, 2011.

LEMOS, Eduardo Martins; NUNES, Eunice P. dos Santos. Hospital Mirim: um serious game como Brinquedo Terapêutico Digital Interativo no apoio a procedimentos médicos. XV SBGames - São Paulo - SP Brazil, September 8th - 10th, 2016.

LEMOS, Isabela Porpino. Análise do comportamento de crianças e seus acompanhantes e auxiliares de enfermagem durante a punção venosa em sessáo de quimioterapia ambulatorial. Disponível em: http://ppgtpc. propesp. ufpa.br/ARQUIVOS/dissertacoes/ISABELA\%20LEMOS\%20 2007.pdf. Acesso em: 10 de abril 2019. 
MACHADO, Liliane dos Santos et al. Serious games baseados em realidade virtual para educação médica. Rev. bras. educ. med., Rio de Janeiro, v. 35, n. 2, p. 254-262, Junho, 2011. Disponível em: http://www.scielo. br/scielo.php?script=sci_arttext\&pid=S0100-55022011000200015\&lng =en \&nrm=iso. Acesso em: 03 de abril 2019.

MANNE, S.L Couples coping with câncer: Research issues and recente findings. Journal os Clinical Psychology in Medical Setting. Disponível em: https://www.ncbi.nlm.nih.gov/pmc/articles/PMC4461872/. Acesso em: 04 de abril 2019.

MORETE, Márcia Carla et al. Tradução e adaptação cultural da versão portuguesa (Brasil) da escala de dor Behavioural Pain Scale. Rev. bras. ter. intensiva, São Paulo, v. 26, n. 4, p. 373-378, dez. 2014. Disponível em: http://www.scielo.br/scielo.php?script=sci_ arttext\&pid=S0103507X2014000400373\&lng=pt\&nrm=iso. Acesso em: 10 de abril 2019.

MOTTA, Alessandra Brunoro; ENUMO, Sônia Regina Fiorim. Intervenção psicológica lúdica para o enfrentamento da hospitalização em crianças com câncer. Psic.: Teor. e Pesq., Brasília, v. 26, n. 3, p. 445-454, Sept. 2010. Disponível em: http://www.scielo.br/scielo.php?script=sci_ arttext $\&$ pid $=S 010237722010000300007 \& \operatorname{lng}=$ en $\& n r m=$ iso. Acesso em: 16 de abril 2019

PARISOD, Heidi; PAARINEN, Anni; KAUHANEN, Lotta; AROMAA, Minna; LEPANNEN, Ville; LIUONNEN, Tapani SMED, Jouni; SALANTERA, Sanna. A health game as an intervention to support tobacco-related health literacy among early adolescents. Disponível em: https:/pdfs.semanticscholar.org/1696/ e356e6362084e4cf3c817491688e95096506.pdf. Acesso em: 13 de abril 2019.

PETTENGIL, Myriam Aparecida Mandetta; CHERON, Maria de Fatima Lima. Experiência do irmáo saio em relação à doença e hospitalização do irmão com câncer. Acta Paul Enferm 2011; São Paulo.

RIBEIRO, Circéa Amália et al. Mesa redonda: O brinquedo e a assistência de enfermagem à criança. Enferm Atual, nov/dez, p. 6-17, 2002. 
RUMOR, Pamela, Camila, Fernandes; BOEHS, Astrid, Eggest. O impacto da hospitalização infantil nas rotinas das famílias monoparentais. Revista Eletrônica de Enfermagem, 15(4), p. 1007-1015, 2013.

SKINNER, Ellen, A, CHI, U. Intrinsic Motivation and Engagement as "Active Ingredients" in Garden-Based Education: Examining Models and Measures Derived From Self-Determination Theory. Disponível em: https:// pdfs.semanticscholar.org/bcb3/8f6e851649697037f121fe04d5c66a20fe34. pdf. Acesso em: 05 de abril 2019. 


\section{EDUCAÇÃO E TRABALHO: \\ MULHERES NO INSTITUTO FEDERAL DE MATO \\ GROSSO (2008 a 2018)}

Silvia Maria dos Santos Stering

Nilce Vieira Campos Ferreira

\section{Introdução}

O Instituto Federal de Educação, Ciência e Tecnologia de Mato Grosso- IFMT, teve origem no ano de 2008, coma Lei no 11.892 , de 29 de dezembro de 2008. Embora seja uma instituição recente, tem suas origens no ano de 1909, mediante Decreto no 7.566, de 23 de setembro, expedido pelo Presidente Nilo Peçanha, quando criou as Escolas de Aprendizes e Artífices- EAAMT, destinadas aos "desvalidos da sorte". A transformação da Escola de Artífices em Liceu Industrial ocorreu por meio da Lei $\mathrm{n}^{\circ} 378$ de 13 de janeiro de 1937, contudo, continuou com a mesma denominação até 1941 quando foi transformada em Liceu Industrial de Cuiabá, via Circular no 1.971 , de 05 de setembro, expedida pelo Ministro Gustavo Capanema.

Ainda na década de 1940, o ensino nacional passou por uma reforma, denominada "Reforma Capanema", em cujo bojo o Liceu Industrial de Mato Grosso foi transformado em Escola Industrial de Cuiabá -EIC, pelo Decreto-Lei no 4.127, de 25 de fevereiro de 1942. Em 1965, recebeu a denominação de Escola Industrial Federal de Mato Grosso, em virtude da Lei $\mathrm{n}^{\circ}$ 4.759, de 20 de agosto, que qualificava as Universidades e Escolas Técnicas da União, sediadas nas capitais dos estados, como instituiçóes federais incorporando a denominação do respectivo estado. Em adequação à lei anterior, o Ministro da Educação e Cultura, Tarso Dutra, expediu a Portaria no 331, de 17 de junho de 1968, alterando novamente a denominação para Escola Técnica Federal de Mato Grosso (ETFMT), nomenclatura instaurada na memória coletiva do povo cuiabano.

No ano de 1994, o Presidente da República, Itamar Franco instituiu o Sistema Nacional de Educação Tecnológica, por força da Lei no 8.948, de 8 de dezembro, que, entre outras medidas, transformou as Escolas Técnicas Federais em Centros Federais de Educação Tecnológica. Porém, sua implantação ficou 
submetida à expedição de um decreto específico emitido pelo Ministro da Educação, após aprovação do projeto institucional de cefetização, apresentado pela interessada e, na atualidade, Institutos Federal de Educação, Ciência e Tecnologia de Mato Grosso- IFMT.

Pautamos, portanto, nosso texto na História das Instituiçóes Escolares, uma vez que ocupar-se da memória institucional consiste em analisar e abordar relatos históricos para chegar à compreensão quanto à sua organização e práticas, afinal nas instituiçóes educativas "se entrelaçam acontecimentos de trabalho, questóes de poder, vínculos libidinais individuais e grupais, inseridos na cultura recortada de cada organização em particular”. (MEZANO, 1998, p.37).

Ao estudar a instituição, procuramos investigar a participação das mulheres no IFMT entre os anos de 2008 a 2018, partimos da concepção de que a instituição, ao longo dos anos marcou-se por uma estrutura patriarcal, na qual os homens se sobrepunham numericamente às mulheres.

Nosso recorte temporal deriva do fato de que, no ano de 2008, o entáo em Centro Federal de Educação Tecnológica de Mato Grosso foi transformado em Instituto Federal de Educação, Ciência e Tecnologia de Mato Grosso, tendo em vista as medidas utilizadas pelo governo federal no período de 2003 a 2006, fase inicial do primeiro mandato do presidente Luiz Inácio lula da Silva, denominada fase de expansão I, para ampliar a política nacional de educação. As decisôes para colocar em prática tal ideário foram desencadeadas em diferentes instâncias administrativas: no Ministério da Educação; nas instituiçóes preexistentes que ofertavam a educação profissional; nas instituiçóes recém criadas e em órgáos locais como prefeituras, em municípios nos quais foram implantados uma unidade de um instituto federal.

A escolha das cidades nas quais foram implantadas novas unidades de Institutos Federais levou em conta três dimensôes estabelecidas pelo governo federal para a expansão da rede, a saber: a dimensão social, geográfica e do desenvolvimento, sendo que, a dimensão social visava à universalização de atendimento aos territórios; a dimensão geográfica objetivava a interiorização da oferta pública de educação profissional e o atendimento aos municípios não atendidos por escolas federais; e a dimensão de desenvolvimento visava atender municípios que possuíam arranjos produtivos já identificados.

O Decreto 6.095 de 24 de abril de 2007 estabeleceu diretrizes para o processo de integração de instituições federais de educação tecnológica, para fins de constituição dos Institutos Federais de Educação, Ciência e Tecnologia - IFET, no âmbito da Rede Federal de Educação Tecnológica e foi 
o primeiro dispositivo legal a tratar do tema da criação dos Institutos Federais de Educação Ciência e Tecnologia, o qual deliberava que "O Ministério da Educação estimulará o processo de reorganização das instituiçôes federais de educação profissional e tecnológica, a fim de que atuem de forma integrada regionalmente" e que esta reorganização se daria pelo modelo de Instituto Federal de Educação, Ciência e Tecnologia. (BRASIL, 2007).

A partir de esse Decreto, o Instituto Federal de Educação, Ciência e Tecnologia de Mato Grosso - IFMT foi criado mediante a integração do Centro Federal de Educação Tecnológica de Cuiabá, do Centro Federal de Educaçáo Tecnológica de Mato Grosso, e da Escola Agrotécnica Federal de Cáceres e de suas respectivas unidades de ensino descentralizadas, a saber: Campo Novo do Parecis, Bela Vista e Pontes e Lacerda, transformados em campi do Instituto.

Encerramos nossa análise em 2018, quando IFMT completou dez anos, pois compreendemos que ao longo desses dez anos a instituição passou por significativas mudanças, principalmente ao considerarmos os espaços ocupados pelas mulheres nessa nova configuraçáo dessa instituiçáo educativa. Podemos dizer que nesses 10 anos houve ganhos substanciais tanto se considerarmos a evolução institucional em relação ao ingresso de mulheres na instituição quanto aos níveis e espaços hierárquicos de atuação que conquistaram.

Consideramos que, no que diz respeito à questão de gênero no IFMT, existe um conflito latente entre homens e mulheres, com certo grau de coerçáo exercido sobre o segmento feminino. Ressalvamos que o IFMT, como toda instituição pública não é isento de um conjunto de interesses. Com isso a abertura para a participação das mulheres na instituição também é parte de um longo processo de busca por garantia de direitos junto a uma instituiçáo, cujo processo de organização, tanto nos aspectos sociais, culturais, educativos e econômicos, têm como pressuposto a invisibilidade feminina.

Lembramos Michelle Perrot (1998) que nos alertou a mulher foi excluída da história. Dessa forma, nesse estudo, evidenciamos a presença das mulheres no IFMT, uma vez que elas também assumiram e assumem papel relevante no processo constitutivo dessa instituição federal pública de ensino.

Diante do exposto, questionamos: quais espaços de trabalho no IFMT e como eles têm sido ocupados pelas mulheres?

$\mathrm{O}$ artigo encontra-se organizado em três partes. A primeira apresenta um histórico da instituição ao longo do tempo. Na segunda parte abordamos a participação feminina na EPT e na nova institucionalização do IFMT. Por último, evidenciamos as estratégias utilizadas pelas mulheres para ocupar 
espaços de trabalho na instituição, reivindicando o direito de ter vez e voz na gestão da instituição, de forma participativa e no interior do contexto de equidade e paridade entre os gêneros.

\section{Origens da instituição: instituição de educação superior, básica e profissional, pluricurricular e multicampi}

Embora a instituição em estudo tenha suas origens em 1909, com a Escola de Aprendizes e Artífices, deteremos nossa análise a partir da Lei no 11.892 , de 29 de dezembro de 2008, publicada no Diário Oficial em 30 de dezembro de 2008, por meio da qual o presidente Luiz Inácio Lula da Silva criou a Rede Federal de Educação Profissional, Científica e Tecnológica para a oferta de educação profissional e tecnológica nas diferentes modalidades de ensino, Educação Superior, Básica e Profissional, articulando e conhecimentos técnicos e tecnológicos às suas práticas pedagógicas. (BRASIL, 2008).

O que aparentemente se apresentou-se como uma novidade, no entanto, encontra-se fundamentado na ideia desenvolvida pelo deputado mineiro Fidelis Reis, no ano de 1922, na qual já pretendia instalar Institutos Politécnicos no Brasil. O projeto apresentado por Fidélis Reis, contudo, foi considerado "o mais radical de quantos projetos já haviam surgido no Brasil a respeito do ensino profissional, pois propunha que o ensino profissionalizante fosse obrigatório no País. Reis lutou pela implantação de mais escolas profissionalizantes, julgando a necessidade da formaçáo de um operariado consciente de sua profissão. (FONSECA, 1961). Afinal, para Reis (1962), a remodelação dos processos de ensino brasileiros criaria " na juventude a vontade realizadora, o espírito construtivo e industrialista, propulsor por excelência do progresso e da riqueza". Com essa concepção propôs as universidades técnicas ou universidades do trabalho.

A universidades técnica ou universidade do trabalho, por cuja fundação tanto nos temos batido, seria a cúpula da organizaçâa magnífica do novo sistema a inaugurar-se. Dentro dele, nos âmbitos d sua vasta estruturação, toda uma seriação de cursos se estabeleceria, vindo das profissóes mais elementares, das escolas do trabalho, em todos os municípios, até a cultura técnica superior, nunca se restringindo o homem o horizonte da cultura, o limite do saber. (REIS, 1962, p. 135). 
Como podemos comprovar no excerto acima, a proposta de Reis já previa um verdadeiro sistema universitário técnico de formação profissional como seria implantado em 2008. Reis destacaria ainda que o ensino profissional como vinha sendo ministrado na República não era mais aceitável, pois dele afastava as elites do país. Para ele a instruçáo ministrada ao estudante deveria "visar principalmente, a aparelhá-lo para a grande luta do trabalho, fecundo e produtivo". (REIS, 1962, p. 144).

O projeto proposto por Fidelis Reis, contudo, foi considerado "verdadeiramente revolucionário", sofrendo forte oposição não foi implantado naqueles anos. (SOARES, 1995, p. 98).

O fato de a educação do trabalhador nascer sob a égide do governo federal em 1909, é no mínimo curioso. O que leva a considerar às intençóes dessa decisão, fazendo-nos acreditar que, desde o princípio da criação da Rede Federal de Ensino, no ano de 1909, suas finalidades tiveram como fundamento o controle por parte do Estado, de maneira clara e objetiva da educaçáo do trabalhador, conforme suas necessidades.

Podemos comprovar essa assertiva analisando a normativa que instituiu a Rede de Ensino Profissional no Brasil. Nela é possível ver que o sistema federal de Educação Profissional deveria ofertar o ensino de ofícios, de forma a atender às especificidades da indústria e dos serviços em cada estado, sob a luz das justificativas oficiais, conforme pode-se observar:

Art. 2० Nas Escolas de aprendizes Artifices, custeadas pela Uniāo, se procurará formar operarios e contramestres, ministrando-se o ensino pratico e os conhecimentos technicos necessarios aos menores que pretenderem aprender um officio, havendo para isso, até o numero de cinco, as officinas de trabalho manual ou mecanica que forem mais convenientes e necessarias no Estado em que funccionar a escola, consultadas, quanto possivel, as especialidades das industrias locaes. (BRASIL, 1909).

Nessa mesma linha de raciocínio, Luiz Antônio Cunha(2000, p. 65-66) descreveu que seria necessário promover "às classes proletárias os meios de vencer as dificuldades sempre crescentes da luta pela existência”, de forma a "habilitar os filhos dos desfavorecidos da fortuna com o indispensável preparo técnico e intelectual, como fazê-los adquirir hábitos de trabalho profícuo".

consideraçóes apresentadas na introdução do Decreto no 7.566, de 1909, demonstravam as motivaçóes vinculadas à criação da Escola de Aprendizes Artífices. Nelas ficam evidentes que o governo brasileiro buscava não só 
resolver os problemas de ordem econômica e política vigentes naquele tempo histórico, como objetivava a formação da força de trabalho industrial de forma imediatista para atender ao capitalismo que avançava pelo Brasil.

Conseiderando que o augmento constante da população das cidades exige que se facilite às classes proletárias os meios de vencer as dificuldades sempre crescentes da lueta pela existencia: que para isso se torna necessario, náo só habilitar os filhos dos desfavorecidos da fortuna com o indispensavel preparo technico e intelectual, como fazelos adquirir habitos de trabalho proficuo, que os afastará da ociosidade ignorante, escola do vício e do crime; que é um dos primeiros deveres do Governo da Republica formar cidadóes uteis à Nação. (BRASIL, 1909, p. 01)

Para Nilce Vieira Campos Ferreira (2014, p. 56), a Educação Profissional firmar-se-ia como "um segmento na relação escola-trabalho. Essa discriminação não foi fruto de ideários trabalho e educação, mas de relaçóes sociais concretas, nascidas no campo da produção". Essa foi uma relação que perdurou nos primeiros anos de existência das escolas técnico-profissionalizantes, fica-nos claro que somente após os anos de 1994, por força da Lei no 8.948, de 8 de dezembro é que este cenário é modificado e motiva o processo de expansão e ressignificação da Rede Federal, a partir da organização dos Institutos Federais, por meio do Decreto no 6.095, de 24 de abril de 2007 e a posterior Lei de criação, Lei no 11.892 de 29 de dezembro de 2008.

Dando continuidade à expansáo da Rede Federal, o governo Lula lançou o Plano de Expansão da RFEPCT, cuja operacionalizaçáo foi dividida em Fase I e Fase II, em que foi lançada a primeira fase do Plano de Expansão da Rede Federal no ano de 2005 com a construçáo de 60 novas unidades de ensino pelo Governo Federal. Neste mesmo ano, o CEFET do Paraná passou a ser Universidade Tecnológica Federal do Paraná através da lei no 11.184, de 7 de outubro de 2005. Fazem parte da I fase da expansão, o Campus Cuiabá - Octayde Jorge da Silva, São Vicente, Cáceres, Bela Vista, Pontes e Lacerda e Campo Novo do Parecis.

Em 2007, aconteceu o lançamento da segunda fase do Plano de Expansão da RFEPCT, tendo como meta entregar à população mais 154 novas unidades, perfazendo um total de 356 unidades em 321 municípios atendidos até o final de 2010, cobrindo todas as regióes do país, oferecendo cursos de qualificação, de ensino técnico, superior e de pós-graduação, sintonizados com as necessidades de desenvolvimento local e regional. Como parte da II fase da expansão do IFMT foram criados os Campus Sorriso, Barra do Garças, Confresa, Juína e Rondonópolis 
No primeiro mandato da Presidente Dilma Rousseff, a partir de 2010, foi garantida não só a conclusão das metas previstas para o período entre 2003 e 2010, como também a continuidade da expansão da Rede Federal. É neste contexto que na III fase da expansão foram criados o Campus Várzea Grande, Alta Floresta, Primavera do Leste, e os Campi avançados de Diamantino, Guarantã do Norte, Lucas do Rio Verde, Sinop e Tangará da Serra.

$\mathrm{Na}$ atualidade, o IFMT, como parte da Rede Federal de Educação Profissional e Tecnológica conta com 14 (quatorze) campi em funcionamento, sendo composto por: Alta Floresta, Barra do Garças, Cáceres, Campo Novo do Parecis, Confresa, Cuiabá - Octayde Jorge da Silva, Cuiabá - Bela Vista, Juína, Pontes e Lacerda, Primavera do Leste, Rondonópolis, São Vicente, Sorriso e Várzea Grande. Possui ainda cinco campi avançados instalados nos municípios de Diamantino, Guarantã do Norte, Lucas do Rio Verde, Sinop e Tangará da Serra.

Como resultado visível das intençôes com a criação dos Institutos Federais, no ano de 2010, o campus Confresa-MT foi fundado como um marco significativo para a Microrregiáo do Norte-Araguaia, pois Confresa é um município que tem $83 \%$ do território ocupado por assentamentos oriundos da reforma agrária. Ali residem cerca de cinco mil famílias assentadas, totalizando 60 assentamentos registrados pela Superintendência Regional do Incra e pela Prefeitura Municipal.

Um ano após a criação do IFMT, o jornal Olhar Direto descreveu os cursos que o IFMT ofertava no estado mato-grossense.

Em seu primeiro ano de vida o IFMT foi o responsável por levar desenvolvimento às regióes onde atua no Mato Grosso. Com oito campi e três núcleos avançados o IFMT oferece 38 cursos nas áreas de bacharelado, licenciatura, tecnologia, cursos técnicos de nível médio (integrados e subsequentes) e cursos de pós-graduação (lato sensu). Para 2010 o IFMT espera mais de 13 mil novos alunos espalhados nas cidades de Mato Grosso onde faz presença através de seus campi, núcleos avançados e através da Universidade Aberta do Brasil (UAB). E para atender a essa demanda nomeou na última quarta-feira (23) mais 97 professores, o que totaliza um quadro de 513 docentes. Mas o IFMT ainda está crescendo. Com a parceria da Prefeitura de Poconé, o IFMT está em processo de criação de mais um núcleo avançado na região pantaneira e está terminando a construçáo de mais dois campi: em Barra do Garças e Rondonópolis. Dessa forma o IFMT 
pretende alcançar todas as regiōes do Estado de Mato Grosso. (OLHAR DIRETO, 2009).

Com status de universidade, os Institutos Federais tornaram-se instituiçóes de educação superior, básica e profissional, pluricurriculares e multicampi, especializados na oferta de educação profissional e tecnológica nas diferentes modalidades de ensino, com base na conjugaçáo de conhecimentos técnicos e tecnológicos e práticas pedagógicas específicas. (BRASIL, 2008).

Os Institutos Federais assumiram a responsabilidade de ofertar educação básica e tecnológica, além da formação em nível superior, pós-graduação latu e stricto sensu, a ainda a Formação Inicial e Continuada -FIC. Consoante o artigo $6^{\circ}$ da lei $n^{\circ} 11.892$, de 29 de dezembro de 2008 que instituiu a Rede Federal de Educação Profissional, Científica e Tecnológica, Seção II, Das Finalidades e Características dos Institutos Federais ,no artigo $6^{\circ}$ determinou a finalidade dessas instituiçóes educativas.

Art. 6o Os Institutos Federais têm por finalidades e características: I - ofertar educação profissional e tecnológica, em todos os seus níveis e modalidades, formando e qualificando cidadãos com vistas na atuação profissional nos diversos setores da economia, com ênfase no desenvolvimento socioeconômico local, regional e nacional;II - desenvolver a educaçáo profissional e tecnológica como processo educativo e investigativo de geração e adaptação de soluções técnicas e tecnológicas às demandas sociais e peculiaridades regionais; III promover a integração e a verticalizaçáo da educaçáo básica à educação profissional e educação superior, otimizando a infraestrutura física, os quadros de pessoal e os recursos de gestão; IV - orientar sua oferta formativa em benefício da consolidação e fortalecimento dos arranjos produtivos, sociais e culturais locais, identificados com base no mapeamento das potencialidades de desenvolvimento socioeconômico e cultural no âmbito de atuação do Instituto Federal;V - constituir-se em centro de excelência na oferta do ensino de ciências, em geral, e de ciências aplicadas, em particular, estimulando o desenvolvimento de espírito crítico, voltado à investigação empírica; VI - qualificar-se como centro de referência no apoio à oferta do ensino de ciências nas instituiçôes públicas de ensino, oferecendo capacitação técnica e atualização pedagógica aos docentes das redes públicas de ensino;VII - desenvolver programas de extensão e de divulgação científica e tecnológica;VIII 
- realizar e estimular a pesquisa aplicada, a produçáo cultural, o empreendedorismo, o cooperativismo e o desenvolvimento científico e tecnológico;IX - promover a produção, o desenvolvimento $\mathrm{e}$ a transferência de tecnologias sociais, notadamente as voltadas à preservação do meio ambiente. (BRASIL, 2008).

Nesta direção, o IFMT a partir de 2008 se configurou como multicampi. A reitoria foi instalada em Cuiabá, composta com o seguinte organograma.

Figura 1 - Organograma básico de um Instituto Federal (Lei № 11.892/ 2008).

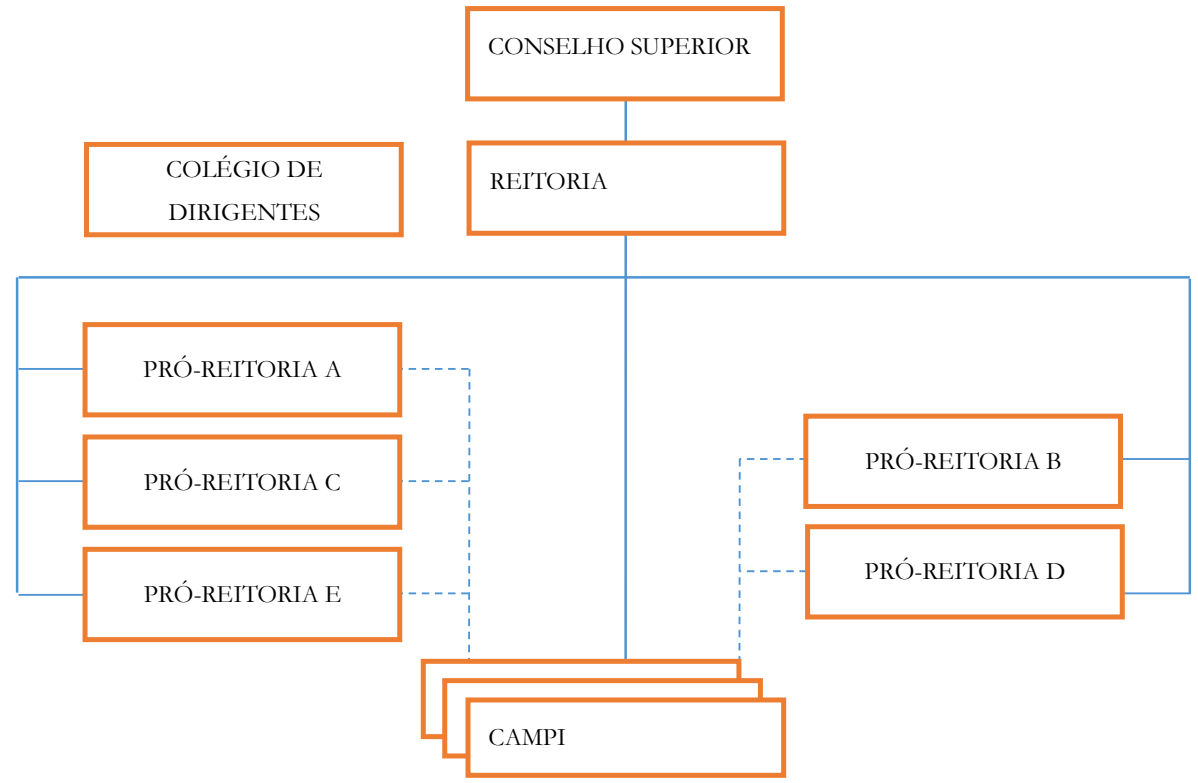

Fonte: Elaborado pela autora (2018).

Como podemos apontar, o IFMT se constituiu como uma instituição de ensino que oferta cursos em várias localidades do estado de Mato Grosso, sendo no total 119 cursos como podemos visualizar no quadro 1. 


\begin{tabular}{|c|c|}
\hline $\begin{array}{l}\text { Concomitante ao } \\
\text { Ensino Médio }\end{array}$ & $\begin{array}{l}\text { Técnico em Administração, Técnico em Secretaria e Técnico em } \\
\text { Informática. }\end{array}$ \\
\hline $\begin{array}{l}\text { Integrados ao Ensino } \\
\text { Médio }\end{array}$ & $\begin{array}{l}\text { Técnico em Administração,Técnico em Agrimensura,Técnico em } \\
\text { Agropecuária,Técnico em Alimentos, Técnico em Biotecnologia,Técnico } \\
\text { em Comércio, Técnico em Controle Ambiental, Técnico em Desenho da } \\
\text { Construção Civil,Técnico em Desenvolvimento de Sistemas, Técnico em } \\
\text { Edificações, Técnico em Eletromecânica, Técnico em Eletrônica, Técnico } \\
\text { em Eletrotécnica,Técnico em Eventos, Técnico em Informática, Técnico } \\
\text { em Logística, Técnico em Manutenção e Suporte em Informática, Técnico } \\
\text { em Meio Ambiente, Técnico em Química, Técnico em Recursos Humanos, } \\
\text { Técnico em Secretariado, Técnico em Telecomunicações. }\end{array}$ \\
\hline $\begin{array}{l}\text { Integrado ao Ensino } \\
\text { Médio - Proeja }\end{array}$ & $\begin{array}{l}\text { Técnico em Administração, Técnico em Alimentos, Técnico em Comércio, } \\
\text { Técnico em Edificações, Técnico em Eletrotécnica, Técnico em Logística, } \\
\text { Técnico em Serviços de Condomínio. }\end{array}$ \\
\hline $\begin{array}{l}\text { Subsequentes ou Pós } \\
\text { Médio. }\end{array}$ & $\begin{array}{l}\text { Técnico em Administração, Técnico em Agrimensura, Técnico em } \\
\text { Agroindústria, Técnico em Agropecuária, Técnico em Alimentos, Técnico } \\
\text { em Biotecnologia, Técnico em Comércio, Técnico em Desenho da } \\
\text { Construção Civil, Técnico em Edificações, Técnico em Eletromecânica, } \\
\text { Técnico em Eletrônica, Técnico em Eletrotécnica, Técnico em Eventos, } \\
\text { Técnico em Florestas, Técnico em Guia de Turismo, Técnico em Logística, } \\
\text { Técnico em Manutenção e Suporte em Informática, Técnico em Química, } \\
\text { Técnico em Recursos Humanos, Técnico em Redes de Computadores, } \\
\text { Técnico em Secretariado, Técnico em Telecomunicações. }\end{array}$ \\
\hline Superiores & $\begin{array}{l}\text { Bacharelado em Administração, Bacharelado em Agronomia, } \\
\text { Bacharelado em Engenharia da Computação, Bacharelado em } \\
\text { Engenharia de Alimentos, Bacharelado em Engenharia de Controle e } \\
\text { Automação, Bacharelado em Engenharia Florestal, Bacharelado em } \\
\text { Secretariado Executivo, Bacharelado em Zootecnia, Licenciatura em } \\
\text { Ciências - habilitação em Biologia, Licenciatura em Ciências Agrícolas, } \\
\text { Licenciatura em Ciências Biológicas, Licenciatura em Ciências da } \\
\text { Natureza, Licenciatura em Ciências da Natureza - habilitação em Química, } \\
\text { Licenciatura em Física, Licenciatura em Matemática, Licenciatura em } \\
\text { Química, Técnico em Análise e Desenvolvimento de Sistemas, Tecnologia } \\
\text { em Agroindústria, Tecnologia em Agronegócio, Tecnologia em Alimentos, } \\
\text { Tecnologia em Análise e Desenvolvimento de Sistemas, Tecnologia em } \\
\text { Automação Industrial, Tecnologia em Biocombustíveis, Tecnologia em } \\
\text { Comércio Exterior, Tecnologia em Construção de Edifícios, Tecnologia } \\
\text { em Controle de Obras, Tecnologia em Geoprocessamento, Tecnologia } \\
\text { em Gestão Ambiental, Tecnologia em Gestão Pública, Tecnologia em } \\
\text { Processos Gerenciais, Tecnologia em Produção de Grãos, Tecnologia em } \\
\text { Redes de Computadores, Tecnologia em Sistemas para Internet. }\end{array}$ \\
\hline
\end{tabular}




\begin{tabular}{|l|l|}
\hline $\begin{array}{l}\text { Concomitante ao } \\
\text { Ensino Médio }\end{array}$ & $\begin{array}{l}\text { Técnico em Administração, Técnico em Secretaria e Técnico em } \\
\text { Informática. }\end{array}$ \\
\hline Pós-Graduação. & $\begin{array}{l}\text { Pós-graduação em História de Mato Grosso, Mestrado em Ciência e } \\
\text { Tecnologia de Alimentos e Pós-graduação em Redes e Computação } \\
\text { Distribuída. }\end{array}$ \\
\hline
\end{tabular}

Fonte: Relatório de Gestão do IFMT- 2017.

Diante do contexto apresentado, cabe questionar: Como as mulheres se colocam no âmbito da instituição? Como participaram e se movimentaram no âmbito dessas mudanças sofridas pelo IFMT ao longo dos anos?

Nossa percepçáo é a de que esse registro também é uma forma de memória do IFMT, pois conforme Justino Magalhães, a história das instituições escolares pode traduzir determinado realidade em evolução.

A história das instituiçóes educativas constituiu um domínio do conhecimento em que se tem operado uma profunda alteraçáo metodológica, uma vez que há uma narrativa de natureza cronística e memorialista, que informa as representaçóes e os relatos orais dos atores se procura contrapor uma base de informação arquivística, sob uma heurística e uma hermenêutica complexa, problematizantes e centradas na instituição educativa como totalidade em organização e desenvolvimento. Uma história construída(s) da(s) memórias(s) para o arquivo e do arquivo para a memória, intentando uma síntese multidimensional que traduza um itinerário pedagógico, uma identidade histórica, uma realidade em evolução, um projeto pedagógico. (MAGALHÂES, 1999, p.61).

Partindo da ideia de Justino Magalhães (1999), buscamos explicar as relaçóes de hierarquia e valores tanto entre as coisas como entre as pessoas, pois tudo o que nela acontece não é em vão nem tão pouco se perde, às vezes permanece ou se transforma.

\section{Mulheres no IFMT}

Ao considerarmos a sociedade brasileira como de base patriarcal, podemos observar que a educação destinada às mulheres sempre esteve vinculada aos papéis sociais imputados a elas, muito embora quase sempre essa história tenha sido desconsiderada ou pouco estudada. Essa realidade foi descrita por Michele Perrot, considerando que "existe um discurso dos 
ofícios que faz a linguagem do trabalho uma das mais sexuadas possíveis. (PERROT 2007, p.178).

Para Perrot (1998), durante o século XIX e início do XX existia uma "harmoniosa" divisão sexual, na qual homens e mulheres tinham bem definidos sua função, papel, tarefa e espaços pré-determinados, o que determinava os ofícios aceitáveis a cada gênero. Para os homens eram destinados os trabalhos com a madeira e os metais, e à mulher, os afazeres ligados ao cuidado com a família e o trabalho com os tecidos.

Com isso os fazeres femininos circunscreviam-se ao cumprimento das atividades "naturais" de sua condição feminina: aprovisionar um espaço doméstico organizado e adequado no que se refere à manutenção da estrutura física, a fim de melhor cuidar dos filhos e familiares. Enfim, as notabilidade femininas, como descrito, por Guacira Lopes Louro e Dagmar Meyer no artigo intitulado "A escolarização do doméstico. A construção de uma escola técnica feminina(1946-1970)", cujo objetivo era a formação da mulher como "profissional hábil, competente e excelente dona de casa". (LOURO e MEYER 1993, p.46).

À formação das mulheres cabia assim propiciar o acesso à atividades relativas à prática da costura, limpeza, às lides culinárias, à alimentação das crianças, enfim, formar uma mulher que deveria ser boa mãe e esposa, portadora de moral sólida e princípios cristãos, condiçôes imprescindíveis para se encontrar um bom partido e se casar, ou como também ressaltado por Ferreira (2014, p. 185) «o destino que o conservadorismo apontava era o das notabilidades femininas tradicionais: a cama e o fogáo, as prendas do lar».

Portanto, de certo modo, a educação profissional durante muitos anos para as mulheres destinou-se a formar as mulheres para a nobre missão fundamental da mulher, que é de esposa e mãe. (LOURO e MEYER, 1993 p.56).

Nessa direção, no início do século $\mathrm{XX}$, as mulheres trabalhadoras praticamente não conseguiam acesso à educação profissional em Mato Grosso. A Escola de Aprendizes Artífices de Mato Grosso - EAAMT, origem do IFMT, desde sua criação, no ano de 1909até 1971 realizava a oferta de cursos exclusivamente para alunos do sexo masculino, o que parece evidenciar o caráter excludente da instituição.

Mesmo com o advento do ensino industrial em substituição ao ensino de artífices, a Escola Industrial de Cuiabá, depois nominada Escola Técnica Federal de Mato Grosso, continuou na fixidez de ofertar vagas apenas a alunos do sexo masculino. A cultura local, cuiabana, tinha o sexo feminino como dependente do masculino, em subordinação explícita. Parte dessa letargia no 
processo de admissão de mulheres naquele estabelecimento de ensino pode ser explicada pelos cursos técnicos promoverem a habilitação para atividades ligadas ao trabalho, até então consideradas exclusivas do sexo masculino e, em parte, porque o parque industrial mato-grossense não existia como expressão econômica antes da abertura das novas fronteiras agrícolas, do chamado “milagre econômico" do final da década de 1960, e até a crise do petróleo em 1973, que ligou Mato Grosso à estrutura produtiva nacional. (KUNZE, 2006).

Um olhar focado na gestáo da instituição pode esclarecer o atraso na oferta de vagas às mulheres. Orlando Nigro dirigiu a instituição ao longo de quase25 anos, de 1941 a 1966, período no qual ocorreu a Reforma Capanema, decisiva para que as escolas da rede federal assumissem o ensino técnico e propusessem vagas às mulheres. A permanência de dirigentes por muito tempo na direção da instituição pode ter colaborado para que nenhuma "ousadia" tenha sido tentada. Outro fato significativo foi a rede de parentela que se formou no corpo administrativo e docente da EAAMT. (KUNZE, 2006).

Somente a partir de 1972 a instituição passou a aceitar a matrícula de mulheres em seus cursos, tendo em vista que, no ano de 1971 com a promulgação da Lei 5.692/71 a oferta da ETFMT passou por uma distinção de nível em razão da oferta exclusiva do ensino técnico de nível médio, no ano de 1972, ano em que é possibilitada a matrícula para mulheres em quatro cursos técnicos: Estradas, Edificaçóes, Eletrotécnica e Secretariado. Inexiste razão explícita para que a oferta de vagas às mulheres só viesse a acontecer a partir de 1972. Contudo, um olhar para a cultura local e nacional, não deixa dúvida quanto à esfera de participaçáo da mulher brasileira na primeira metade do século XX, quase que restrita ao âmbito doméstico nas classes menos favorecidas e mera coadjuvante nas classes dominantes.

Em relação às profissionais que atuaram no IFMT, Kunze (2009) relatou que a primeira professora a lecionar na EAAMT foi Ana Izabel de Campos Barros que assumiu o cargo de professora do curso noturno primário, que funcionava das $17 \mathrm{~h}$ às $20 \mathrm{~h}$, até o ano de 1911, e que depois passou a denominar-se curso primário, funcionando das 7 h30 às $11 \mathrm{~h} 30$. Barros foi nomeada no dia 18 de dezembro de 1909, pelo Ministério da Agricultura, Indústria e Comércio, órgáo ao qual a escola estava vinculada, tendo sido empossada no dia 24 de janeiro de 1910. Ao longo dos seus trinta anos de trabalho na EAAMT, a professora Ana Izabel, além de lecionar, por diversas vezes desempenhou a atividade de escriturária substituta.

Ainda Kunze (2009) descreveu que ela, mesmo sendo indicada pelo diretor, Pedro Gardés, no momento de sua posse precisou da apresentaçáo 
de autorização do pai e atestado de boa conduta emitido por uma autoridade policial. Ela tinha apenas o curso primário e não era normalista, conforme exigia o regulamento escolar para essa função profissional.

Para Elisabeth MadureiraSiqueira (2000) esse era um dos maiores problemas com o qual Mato Grosso se deparava: a falta de professores formados para o magistério. A administração pública argumentava que semelhante realidade era consequência da falta de investimento e efetivação de uma Escola Normal, várias vezes aberta e encerrada.

Kunze (2009), esclarece que, além de Ana Izabel de Campos Barros, professora primária pertencente ao quadro efetivo da escola, a EAAMT contou com a colaboração profissional de outras docentes, como Elvira Barros Moreira que assumiu a cadeira de adjunta de professora primária no quadro temporário, nos anos de 1912 a 1915. Semelhante cargo foi exercido, no ano de 1933 também por Elza Pires de Arruda.

Foi somente no ano de 1938 que a primeira normalista adentrou EAAMT. Olga Corrêa de Almeida atuou como coadjuvante do ensino de $3^{a}$ classe, nomenclatura dada à adjunta de professora primária até 1940, quando se mudou para o Rio de Janeiro. Em sua substituiçáo assumiu a profa. Maria de Lara Pinto, diplomada no curso secundário e que, em 1941, assumiu as aulas dos cursos noturnos. (KUNZE, 2009).

A partir de 1938, mais mulheres adentraram o quadro do IFMT e construíram história. Segundo dados do GDRH CEFET (2007), levantados por Figueiredo (2008), no ano de 1970 eram professoras da ETFMT Edna Albuquerque Affi e Judith Guimarães Cardoso, ambas se tornariam anos depois, diretoras da escola. As professoras eram parte da equipe pedagógica que deliberava sobre a política da educação na esfera da ETFMT. Elas foram personagens decisivas na emergência feminina que se deu a partir de 1972 no cenário da instituição.

A participação das mulheres no corpo docente, ainda que tímida, sempre existiu no CEFETMT desde a sua fundação. Na Escola de Aprendizes e Artífices, posteriormente ginásios industriais e técnicos de nível médio apresentavam como partes dos seus currículos formativos o que se denomina de formação geral e profissional nos cursos técnicos, até a reforma da educação profissional em 1997 . Em geral, as mulheres atuavam nas disciplinas voltadas para a formação geral.

Em janeiro do ano de 2007, o CEFETMT contava no seu quadro docente com 16 doutores, 70 mestres, 135 especialistas e 36 graduados, sendo que as mulheres com mestrado eram em maior número $38,54,28 \%$, e minoria entre 
os doutores e especialistas. A explicação para o fato da maioria das mulheres serem mestras, está ligada às áreas educacionais. As professoras com mestrado atuavam na área Propedêutica, eminentemente feminina, e Química, em função de sua gênese a partir da reuniáo dos professores com licenciatura em química, a maioria feminina, e os bacharéis em química e engenharia. Parte significativa dos mestrados nessas áreas são em educação, realizados na Universidade Federal de Mato Grosso -UFMT. (FIGUEIREDO, 2008).

Tabela 1 - Docentes distribuídos por área e sexo conforme titulação.

\begin{tabular}{|c|c|c|c|c|c|c|c|c|c|c|c|c|c|c|c|c|}
\hline \multirow{3}{*}{ Área } & \multicolumn{16}{|c|}{ Titulação } \\
\hline & \multicolumn{4}{|c|}{ Doutores } & \multicolumn{4}{|c|}{ Mestres } & \multicolumn{4}{|c|}{ Especialistas } & \multicolumn{4}{|c|}{ Graduados } \\
\hline & $\mathrm{F}$ & M & $\begin{array}{c}\mathrm{F}+ \\
\mathrm{M}\end{array}$ & $\begin{array}{c}\mathrm{F} / \mathrm{F}+ \\
\mathrm{M}(\%)\end{array}$ & $\mathrm{F} \mid \mathrm{M}$ & $\mathrm{M} F$ & $\begin{array}{l}=+ \\
M\end{array}$ & $\begin{array}{c}\mathrm{F} / \mathrm{F}+ \\
\mathrm{M} \\
(\%)\end{array}$ & $\mathrm{F}$ & $\mathrm{M}$ & $\begin{array}{l}\mathrm{F}+ \\
M\end{array}$ & $\begin{array}{c}\mathrm{F} / \mathrm{F}+ \\
\mathrm{M} \\
(\%)\end{array}$ & $\mathrm{F}$ & $M$ & $\begin{array}{l}\mathrm{F}+ \\
\mathrm{M}\end{array}$ & $\begin{array}{c}\mathrm{F} / \mathrm{F}+ \\
\mathrm{M} \\
(\%)\end{array}$ \\
\hline Construção Civil & 1 & 1 & 2 & 50,00 & 3 & 7 & 10 & 30,00 & 4 & 18 & 22 & 18,18 & 0 & 6 & 6 & 0,00 \\
\hline Eletro- eletrônica & 2 & 3 & 5 & 40,00 & 01 & 11 & 11 & 0,00 & 3 & 25 & 28 & 10,71 & 0 & 7 & 7 & 0,00 \\
\hline Informática & 0 & 4 & 4 & 0,00 & 4 & 5 & 9 & 44,44 & 4 & 1 & 5 & 80,00 & 0 & 2 & 2 & 0,00 \\
\hline Propedêutica & 1 & 3 & 4 & 25,00 & 21 & 62 & 27 & 77,77 & 30 & 29 & 59 & 50,84 & 8 & 9 & 17 & 47,05 \\
\hline Química & 1 & 0 & 1 & 100,00 & 6 & 3 & 9 & 66,66 & 1 & 8 & 9 & 11,11 & 1 & 2 & 3 & 33,33 \\
\hline Serviços & & & & & 4 & 0 & 4 & 100,00 & 9 & 3 & 12 & 75,00 & 1 & 0 & 1 & 100,00 \\
\hline CEFETMT & 5 & 11 & 16 & 31,25 & 383 & 327 & 70 & 54,28 & 51 & 84 & 135 & 37,77 & 10 & 26 & 36 & 27,77 \\
\hline
\end{tabular}

Fonte: Ordem Administrativa 01/GD/CEFETMT - 30 janeiro de 2007. Elaborada por Figueiredo (2008).

A Tabela 2expõe a evolução do número de docentes entre 1984 e 2007 em relação ao currículo ministrado - formação geral e profissional. Em todo o CEFETMT o aumento foi de $1,36 \%$ de mulheres e no caso do currículo da formaçáo geral diminuiu a proporção de mulheres em 1,07\%. $\mathrm{O}$ acréscimo de mulheres no CEFETMT é explicado pelo aumento de professoras no currículo profissional, docentes que ministram aulas de matérias ou disciplinas exclusivamente técnicas, e uma queda sutil na 
formação geral. O currículo profissional teve aumento significativo, se comparado com o CEFETMT, de 4,73\%. Essa ampliaçáo condiz com a evolução da oferta de cursos nas áreas educacionais diversas da Construçáo Civil e Eletroeletrônica e Serviços como Informática e Química que não existiam no ano de 1984. (FIGUEIREDO, 2008).

Tabela 2 - Evolução do corpo docente por Parte do Currículo segundo o sexo - 1984/2007.

\begin{tabular}{l|c|c|c|c|c|c}
\hline \multirow{2}{*}{ Parte do Currículo } & \multicolumn{5}{|c}{ Período } \\
\cline { 2 - 7 } & \multicolumn{3}{|c}{1984} & \multicolumn{2}{c}{2007} \\
\cline { 2 - 7 } & F & M & $\begin{array}{c}\text { F/(F+M) } \\
\%\end{array}$ & F & M & F/(F+M) \\
\hline Formação Geral & 28 & 21 & 57 & 60 & 47 & 56 \\
\hline Profissional & 15 & 46 & 24,5 & 44 & 106 & 29,3 \\
\hline Currículo Integral & 43 & 67 & 39 & 104 & 153 & 40 \\
\hline Total de docentes & & 110 & & & 257 & \\
\hline
\end{tabular}

Fonte: GDRH -CEFETMT (2007) e Albuquerque (1984, p. 104-109). Elaborada por Figueiredo (2008).

A Tabela 3 evidencia a evolução do corpo docente por área e sexo, o que nos auxiliou desvelar da visibilidade feminina no quadro docente do CEFETMT. Houve aumento tanto nas áreas educacionais da Construçáo Civil quanto da Eletro- eletrônica e um declínio quase insignificante da área de Serviços. Ainda que o quadro nas áreas mais masculinas do CEFETMT tenha melhorado, continua pequena a participação de mulheres nas áreas de Eletro-eletrônica, 9,80\%, e Construção Civil, 20\%. A visibilidade feminina aumentou com o advento das novas áreas educacionais: Informática com 40\% de mulheres e Química com 45\%. 
Tabela 3 - Evolução do corpo docente por área educacional e sexo - 1984/2007.

\begin{tabular}{l|c|c|c|c|c|c}
\hline \multirow{2}{*}{$\begin{array}{c}\text { Área de } \\
\text { conhecimento }\end{array}$} & \multicolumn{5}{|c}{1984} & \multicolumn{3}{c}{2007} \\
\cline { 2 - 7 } & M & H & $\begin{array}{c}\text { F/(F+M) } \\
(\%)\end{array}$ & $M$ & $H$ & $\begin{array}{c}\text { F/(F+M) } \\
(\%)\end{array}$ \\
\cline { 2 - 7 } Construção Civil & 4 & 28 & 12,50 & 8 & 32 & 20 \\
\hline Eletro-eletrônica & 1 & 16 & 5,88 & 5 & 46 & 9,80 \\
\hline Serviços & 10 & 2 & 83,33 & 14 & 3 & 82,35 \\
\hline Informática & 0 & 0 & - & 8 & 12 & 40,00 \\
\hline Química & 0 & 0 & - & 9 & 13 & 45,00 \\
\hline Total & 15 & 46 & 24,60 & 44 & 106 & 28,94 \\
\hline
\end{tabular}

Fonte: GDRH -CEFETMT (2007) e Albuquerque (1984, p. 104-109). Elaborada por Figueiredo (2008).

Até o ano de 1971, inexistia professoras para as disciplinas técnicas ou profissionalizantes. Mesmo depois da existência de professoras para essa especificidade, o a participação feminina era pequena. Conforme os dados do GDRH - CEFETMT (2007), levando em conta as áreas de educacionais a proporção de mulheres em relaçáo aos homens era pouco significativa, somente cinco eram engenheiras entre as 14 professoras, as demais compunham o quadro do curso de Secretariado. As engenheiras professoras lecionavam as disciplinas introdutórias como Desenho Básico; as disciplinas consideradas mais tecnológicas como as de cálculo estrutural e de projetos eram destinadas aos engenheiros professores.

O emprego público, na primeira metade do século XX, era preferencialmente masculino, fato que certamente conduziu a instituição a não ofertar vaga às mulheres, situação que levaria à contratação de mulheres como docentes, visto que ser professora correspondia à reprodução das atividades domésticas no tratamento maternal das crianças. Além disso, o imperativo dos mestres e contramestres do antigo ensino de artífices foi decisivo para que, somente 25 anos depois do início dos cursos técnicos na rede federal, fossem ofertadas vagas às mulheres na então ETFMT. 


\section{Mulheres e o trabalho no IFMT: conquistas recentes.}

$\mathrm{Na}$ busca por evidenciar o percurso percorrido pelas mulheres para conquistar espaço de participaçáo no IFMT, frente ao lento processo de transformação da identidade da instituição, destacamos o aumento significativo do número de mulheres e sua participação na gestão da instituição. Segundo números extraídos da base de dados do governo federal, no Sistema Unificado de Administração Pública -SUAP, atualmente o IFMT possui 1.818 servidores em todo o estado.

Quadro 2 - Mulheres no IFMT.

\begin{tabular}{|c|c|c|c|}
\hline Total & Mulheres & $\begin{array}{c}\text { Docentes } \\
\text { Mulheres }\end{array}$ & $\begin{array}{c}\text { Técnicas } \\
\text { Administrativas }\end{array}$ \\
\hline 1818 & 761 & 358 & 403 \\
\hline
\end{tabular}

Fonte: o Sistema Unificado de Administração Pública - SUAP.

Temos como exemplo de atuação feminina a profa. Tereza Irene Ribeiro de Carvalho Malheiros, docente titular do Curso de Eletrotécnica, tendo sido aluna da primeira turma do curso, no ano de 1971. Concluiu estes estudos no ano de 1975 e desde entáo permaneceu na instituição como docente, atendendo ao convite do Coronel Octayde Jorge da Silva, então Diretor da instituição. Professora Doutora em Filosofia no IFMT - Campus Cuiabá, com 30 anos de atuaçáo docente, foi a primeira professora a ascender à classe de titular no IFMT. (RH do IFMT, 2018).

No Brasil, embora o magistério, especialmente o de ensino fundamental,tenha sido por muito tempo um espaço feminino, no tocante à docência em educação profissional a presença das mulheres foi perpassada por grande resistência. Considerando a sociedade brasileira como machista, a realidade não poderia ser diferente, já que as mulheres não poderiam ensinar aquilo que não sabiam fazer, justificando a base biológica de exclusão do sexo feminino, conforme afirma Michelle Perrot.

O velho discurso retoma no século XIX um novo vigor, apoiando-se nas descobertas da medicina e da biologia. É um discurso naturalista, que insiste na existência de duas 'espécies' com qualidades e aptidōes particulares. Aos homens, o cérebro (muito mais importante do que o falo), a inteligência, a razão lúcida, a capacidade de decisão. Às mulheres, o coração, a sensibilidade, os sentimentos. (PERROT, 1998, 177). 
Primeira doutora da instituição, Tereza Irene Ribeiro de Carvalho Malheiros concluiu o doutoramento no ano de 1994, pela Universidade de New Castle, na Inglaterra.

Nádia Cuiabano Kunze, Técnica em Assuntos Educacionais, datando de dezembro de 1984 seu vínculo inicial com a Escola Técnica Federal de Mato Grosso, quando prestou o exame de seleção para ingresso no Curso Técnico de Secretariado. Aprovada, efetuou a matrícula e iniciou os estudos em 1985, finalizando-os em 1987. Mesmo tendo concluído todas as disciplinas do curso de $2^{\text {a }}$ grau técnico, Nádia optou por não fazer o estágio supervisionado, recebendo o título de Auxiliar Técnico em Secretariado, conforme Lei n. 7.044, de 18.10.1982, e pôde prosseguir nos estudos de nível superior, concluindo, assim, o Curso de Pedagogia na Universidade Federal de Mato Grosso em 1991.

Foi aprovada em concurso público no Ministério da Educação e do Desporto para o cargo de Técnica em Assuntos Educacionais de Nível Superior, em 1984, exercendo as atividades de analista de financiamento de projetos educacionais municipais e estaduais e de planejamento de políticas nacionais da educação, com lotação na Delegacia do MEC em Mato Grosso.

Com a reforma administrativa implementada pelo governo de FHC, a DEMEC-MT foi extinta em 1998, e os servidores que não optaram pelo Plano de Demissão Voluntária (PDV) tiveram que solicitar vinculação funcional a outro órgão do poder executivo federal.

Nádia Cuiabano Kunze solicitou enquadramento na ETFMT e, desde então, desenvolve, dentre outras, as seguintes atividades: Gestão escolar Coordenação de pesquisa, coordenação de produção e desenvolvimento, coordenaçáo de Minter, coordenação de pós-graduaçáo; Assessoramento nas atividades de ensino, pesquisa e extensão; Planejamento, análise, supervisão, orientação e avaliação do processo educativo; Elaboração de normativas e regulamentos em comissóes institucionais; Organização, elaboração e execução de periódico e eventos científicos institucionais; Pesquisas e estudos científicos sobre EPT, história da instituição escolar e da educação profissional, arquivos escolares, memória e identidade institucional; Publicação de resultados de pesquisas científicas; Capacitação continuada -cursos de aperfeiçoamento, atualização, pós-graduação: mestrado e doutorado; Membro de bancas avaliadoras de concursos e de trabalhos de conclusão de cursos -TCC, Monografias, Dissertaçóes, teses; Parecerista ad hoc de periódicos e eventos científicos e de agências de fomento à projetos científicos, entre outras. 
A trajetória de Kunze vem ao encontro do que Carla Cabral e Walter Bazzo (2005) destacam quanto ao acesso à leitura e à escrita, que, em contexto histórico, de meados do século XVII, foi alterando o lugar da mulher nas sociedades e, consequentemente, sua participação em carreiras científicas e tecnológicas. Fica evidente que, na atualidade, o acesso das mulheres a todas as carreiras é livre, contudo, ainda existem inúmeras barreiras que restringem sua participação na produção do conhecimento científico e tecnológico, restrição tanto hierárquica quanto territorial, num universo majoritariamente masculino, não só no que se refere à pesquisa, mas também ao trabalho.

Nadja Gomes Machado, servidora integrante do quadro de professores do Instituto Federal de Mato Grosso (IFMT), Campus Cuiabá - Bela Vista, faz parte do programa de Bolsa Produtividade em Pesquisa (Bolsa PQ), oferecido pelo Conselho Nacional de Desenvolvimento Científico e Tecnológico (CNPq), vinculado ao Ministério da Ciência e Tecnologia. Semelhante bolsa é destinada aos pesquisadores que se destacam,dentre os profissionais de uma mesma área, na produção científica.

A proposta do programa é conceder esse apoio aos pesquisadores de todas as áreas do conhecimento, enquanto valorização e incentivo à produção científica. $\mathrm{O}$ título concedido à professora reflete também nas produçôes científicas executadas no âmbito do IFMT - Bela Vista, colocando esse bairro de Cuiabá como referência no quadro de docentes, entre os Campi de Mato Grosso: "As bolsas de produtividade oferecidas pelo CNPq configuram como um termômetro para a qualidade do profissional, programas de pósgraduação e também para a Instituição de Ensino" (ASCOM,16/01/2018).

Professora do Campus do IFMT - Bela Vista há 10 anos, coordena o laboratório de Biologia da Conservação (Labic), que tem foco nos estudos relacionados à compreensão do funcionamento, estrutura e dinâmica de ecossistemas naturais e modificados pelo homem. Elaé Graduada em Ciências Biológicas (2004), Mestre em Ecologia e Conservação da Biodiversidade (2007) e Doutora em Física Ambiental (2013) pela Universidade Federal de Mato Grosso (UFMT), fez Estágio Pós-Doutoral em Ciências Ambientais na Utah State University (2014-2015). A carreira da docente em questão foge a lógica defendida por Cabral e Bazzo (2005, p. 3), que afirmam que as mulheres, historicamente, foram afastadas do círculo criativo e da liderança da produção científica e tecnológica.

$\mathrm{Na}$ atual gestão, dentre os 19 campi, o IFMT conta com 3 gestoras . O campus Várzea Grande, com a Professora Sandra Maria de Lima, mediante 
Portaria no 871 D.OU, de 20/04/17, que é graduada em Engenharia Civil pela Escola de Engenharia de Lins,no ano de 1991. Especialista em Engenharia Ambiental pela Faculdade de Saúde Pública da USP,no ano de 1997, mestra em 2006 e doutora em 2008 em Engenharia Civil, pela Escola de Engenharia de São Carlos - USP, área de concentraçáo Engenharia de Estruturas.

De acordo com Schiebinger (2001, p. 61), as mulheres "[...] com frequência prosperavam em campos, como a física e a matemática, considerados, hoje, especialmente resistentes às incursóes femininas". A trajetória de Sandra evidencia tal perspectiva.

Diretora do Campus Rondonópolis, por Portaria no 862, de 19 de abril de 2017, o qual oferta quatro cursos de Ensino Médio Integrado e três de Ensino Superior, além de cursos de extensão, tendo, assim, em torno de 700 alunos e 130 servidores, a saber: Laura Caroline Ayoama Barbosa, bacharel em Biblioteconomia e Documentação pela UFMT, com especialização em Gestão da Educação Profissional e Tecnológica, também pela UFMT, e o título de Mestre em Ciência Política,pela UFPE.

É crescente o aumento do número de mulheres e seu protagonismo no IFMT, assim como no mercado de trabalho. Contudo, há que se considerar a existência de uma dupla dimensáo, pois "[...] de um lado a conquista de bons empregos, o acesso a carreiras e profissóes de prestígio e a cargos de gerência, e mesmo de diretoria, por parte de mulheres escolarizadas, e de outro o predomínio do trabalho feminino em atividades precárias e informais". (BRUSCHINI; LOMBARDI, 2006, p. 63).

Gilma Silva Chitarra, Portaria no 870, de 19.04.2017, é diretora do campus do IFMT Sinop. A professora é graduada em Agronomia pela Faculdade de Agronomia e Zootecnia Manoel Carlos Gonçalves, no ano de 1984, mestra em Agronomia em Fitopatologia, pela Universidade Federal de Lavras, no ano de 1996, e doutora em Nutrição,Tecnologia e Biotecnologia de Alimentos - Wageningen University And Research Centre, no ano de 2003, revalidado pela Universidade de Lavras - MG, Doutorado em Agronomia/Fitopatologia. É professora de Mestrado em Ciência e Tecnologia de Alimentos do IFMT - Campus Bela Vista.

É perceptível a conquista do espaço pelas mulheres no IFMT, assim como são evidentes as transformaçóes que envolvem sua participaçáo na sociedade brasileira, transformaçôes que as mulheres no IFMT não estão imunes, o que nos leva a concordar com Perrot (2007, p. 15), ao afirmar que "a história das mulheres mudou". 
Em seus objetos, em seus pontos de vista. Partiu de uma história do corpo e dos papéis desempenhados na vida, privada para chegar a uma história das mulheres no espaço público da cidade, do trabalho, da política, da guerra, da criaçáo. Partiu de uma história das mulheres vítimas para chegar a uma história das mulheres ativas, nas múltiplas interaçóes que provocam a mudança. (PERROT, 2007, p. 15).

A chegada das mulheres ao espaço público se deu por meio de sua entrada na educação básica, sendo que o ensino era considerado enquanto forma de fortalecer os aprendizados inerentes às suas atribuiçóes na esfera domésticas, limitando o seu conhecimento em outras áreas. Posteriormente, sua inserçáo no ensino superior e a entrada no mercado de trabalho foram influenciadas por suas obrigaçóes domésticas. Tal situação levou as mulheres a se concentrar em áreas voltadas especificamente para o cuidar e o educar, ficando a área tecnológica fora desta intenção.

Contemporaneamente, assistimos as mulheres atuar nas mais diversas áreas, incluindo as de ciência e tecnologia, o que as coloca, mesmo que minoritariamente, num campo de trabalho que, até poucos anos atrás, estava restrito aos homens.

\section{Algumas considerações}

Se por um lado admite-se que uma educação a serviço do mundo do capital possui sua função desvirtuada, cumprindo, portanto, uma disfunção, contudo, sem que seja possível prescindir de sua importância, talvez a finalidade dos Institutos Federais esteja a serviço da ideologia da divisão de forças, e não ao contrário, razão pela qual eles possuem uma reitoria localizada distante dos campi pulverizados em todo o estado, como é o caso de Mato Grosso.

O objetivo desta investigação foi o de dar a conhecer a participação da mulher no Instituto Federal de Educação, Ciência e Tecnologia de Mato GrossoIFMT, tendo por foco os dez anos de existência da nova institucionalização, sob esta nomenclatura, tendo sido as hipóteses, levantadas inicialmente, confirmadas plenamente.

A educação profissional Brasil nasceu perpassada pela dualidade, cuja marca é adistribuição de renda desigual que se fortalece na desigual distribuição do conhecimento o que também afeta diretamente as mulheres.

Ao percorrermos a trajetória feminina na busca por espaço de participação na EPT, nos últimos dez anos no IFMT, é possível visualizar que o início 
das atividades intelectuais da mulher na instituição, aconteceram com o nascimento da modernidade, e sua inclusáo social se deu sob o signo da instrumentalização do sexo.

O século XIX foi determinante para a manutenção da cultura patriarcalista no Brasil, na qual a mulher tinha que prestar contas ao pai, ao marido, enfim, a toda a sociedade e, mas também ao Estado. $\mathrm{O}$ movimento para sua inicial emancipaçáo ocorreu no campo educacional, considerado como segundo lar, e a professora qualificada pelo "instinto" maternal, táo suave e severa quanto na educação de seus próprios filhos.

Uma vez que a participação da mulher no plano social exigiu treinamento e exercício constante, ainda que necessitasse de apoio e vigilância ao longo de décadas, a entrada da mulher na EPT se deu na perspectiva de sua contribuição no processo de modernização do país, em que a educação de base era promovida pelo Estado, e de forma agradável e facilitada, visto que desenvolvida por mulheres.

Conforme evidenciado neste artigo, a conquista do espaço para a participação da mulher na instituição se deu pela via do conhecimento científico, cada vez mais presente na no cotidiano das docentes e técnicas que fizeram parte do quadro de servidores da instituição. $\mathrm{Na}$ atualidade, muitas pesquisadoras do IFMT são destaque em produtividade e inovação, em suas áreas de pesquisa. Elas trazem olhares diferenciados para o fazer científico e isso beneficia a produção de conhecimento. Nessa medida, a ciência pode ser um caminho para o empoderamento feminino.

A instituição tem exemplo de mulheres que, além de buscar soluçóes tecnológicas para os setores produtivos, estáo ajudando a aumentar o poder desse segmento e a construção da igualdade de gênero em outros espaços sociais, tendo em vista que é importante trazer visibilidade para o trabalho e para os saberes produzidos por mulheres, numa perspectiva que vá além dos espaços acadêmicos.

No entanto, importante se faz lembrar que não basta somente fazer ciência, atuar na academia, mas contribuir de forma incisiva com o debate sobre sua condição, para que haja reconhecimento do trabalho das mulheres. A nosso ver, o primeiro passo para que os trabalhos de mulheres sejam mais valorizados na instituição e fora dela é garantir que elas tenham oportunidade para realizá-los. Para isso, é preciso, desde cedo, incentivar meninas a se interessar pelos mais diversos assuntos, para que suas escolhas de carreira não sejam limitadas às opçóes tradicionais, oferecendo para além disso, outras e inúmeras oportunidades. 


\section{Referências}

BRUSCHINI, Cristina; LOMBARDI, Maria Rosa; UNBEHAUM, Sandra. Trabalho, renda e políticas sociais: avanços e desafios. In: O Progresso das mulheres no Brasil. Brasília: Fundação Ford; Cepia, 2006. p. 60- 93. Disponível em http:/www.mpsp.mp.br/portal/page/portal/Cartilhas/Progresso\%20das\%20 Mulheres\%20no\%20Brasil.pdf. Acesso em 15 abr. 2019.

A MULHER. O Progresso das mulheres no Brasil. Brasília: Fundação Ford; Cepia, 2006. p.60- 93.

CABRAL, Carla Giovana; BAZZO, Walter Antônio. As mulheres nas escolas de engenharia brasileiras: história, educação e futuro. Revista de Ensino de Engenharia, v. 24, n. 1, p. 3-9, 2005.

CUNHA, L. A. O ensino de ofícios nos primórdios da industrializaçáo. São Paulo: Editora UNESP, Brasília, DF: Flocos, 2000.

FERREIRA, Nilce Vieira Campos. Economia Doméstica: ensino profissionalizante feminino no triângulo mineiro (Uberaba/MG - 19531997). Jundiaí: Pacto Editorial, 2014.

FIGUEIREDO. Luiz Carlos. O gênero na educaçáo tecnológica: uma análise de relaçóes de gênero na construçáo de habilidades e competências da Área de Construção Civil do Centro Federal de Educação Tecnológica de Mato Grosso. Dissertação de Mestrado. Campinas, SP 2008.

FONSECA, Celso Suckow da. História do ensino industrial no Brasil. Rio de Janeiro: Escola Técnica Nacional do Rio de Janeiro, 1961. v.1.

KUNZE. Nádia Cuiabano. A Escola de Aprendizes Artífices de Mato Grosso 1909/1941. Cuiabá: EdUFMT; CEFETMT, 2006.

KUNZE. Nádia Cuiabano. A inserção da mulher na história do IFMT. In: Seminário sobre Gênero na História do Magistério do Estado de Mato Grosso; Encontro Nacional de Estudos Dirigidos para Mulheres ENEDIM, 3., 2009, Cuiabá. Cuiabá: IFMT; UNEMAT, nov. 2009. p. 1-5. (Palestra apresentada).

LOURO, Guacira Lopes e MEYER, Dagmar. A Escolarização do Doméstico: a contrucão de uma escola técnica feminina (1946-1970). Cadernos de Pesquisa. São Paulo, No 87. p.45-57. nov. 1993.

MAGALHĀES, Justino Pereira de. Tecendo nexos: história das instituições educativas. Bragança Paulista/SP: Editora Universitária São Francisco, 1999. 
MEZZANO, Alicia Corvalénde. Lembranças pessoais, memórias institucionais: para uma metodologia de questionamento históricoinstitucional. In: BUTELMAN, Ida (org.). Pensando as instituiçóes: teorias e práticas em educação. Porto Alegre: Artmed. 1998.

PERROT, Michelle. Minha história das mulheres. Tradução: Angela Maria da Silva Corrêa. São Paulo: Contexto, 2007.

PERROT, Michelle. Os excluídos da História: operários, mulheres e prisioneiros. Tradução: Denise Bottmann. 2. ed. Rio de Janeiro: Paz e Terra, 1998.

REIS, Fidélis. Homens e problemas do Brasil. Rio de Janeiro, Editora José Olympio, 1962.

SCHIEBINGER, Londa. Mais mulheres na ciência: questôes de conhecimento. Apresentação de Maria Margaret Lopes. História, Ciências, Saúde - Manguinhos, Rio de Janeiro, v.15, supl., p.269-281, jun. 2001.

SIQUEIRA, Elizabeth Madureira. Luzes e sombras: modernidade e educação pública em Mato Grosso (1870-1889). Cuiabá: EdUFMT, 2000.

SOARES, Manoel Jesus.Uma nova ética do trabalho nos Anos 20: Projeto Fidelis Reis. Série Documental/Relatos de Pesquisa n. 33. Universidade Santa Úrsula, 1995.

\section{Leis, despachos, decretos e portarias}

BRASIL. Decreto Lei no 4.127 de 25 de fevereiro de 1942. Estabelece as bases de organização da rede federal de estabelecimentos de ensino industrial. Brasília, 1942.

BRASIL. Decreto $\mathbf{n}^{\circ} \mathbf{6 . 0 9 5}$ de 24 de abril de 2007. Estabelece diretrizes para o processo de integraçáo de instituiçóes federais de educação tecnológica, para fins de constituição dos Institutos Federais de Educação, Ciência e Tecnologia - IFET, no âmbito da Rede Federal de Educação Tecnológica. Brasília, 2007.

BRASIL. Decreto no 7.566, de 23 de setembro de 1909. Cria nas capitais dos Estados as Escolas de Aprendizes Artífices, para o ensino profissional primário e gratuito. De 23 de Setembro de 1909.

BRASIL. Lei no 11.892, de 2008. Institui a Rede Federal de Educaçáo Profissional, Científica e Tecnológica, cria os Institutos Federais de Educação, Ciência e Tecnologia, e dá outras providências. Brasília, 2008. 
BRASIL. Lei no 378 de 13 de janeiro de 1937. Dá nova organização ao Ministério da educação e Saúde Pública. Brasília, 1937.

BRASIL. Lei no 4.759 de 20 de agosto de 1965. Dispóe sobre a denominação e qualificação das Universidades e Escolas Técnicas Federais. Brasília, 1965.

BRASIL. Lei no 5.692 de 11 de agosto de 1971. Fixa Diretrizes e Bases para o ensino de $1^{\circ}$ e $2^{\circ}$ graus, e dá outras providências. Brasília, 1971.

BRASIL. Lei no 7.044de 18 de outubro de 1982. Altera dispositivos da Lei $\mathrm{n}^{\mathrm{o}}$ 5.692, de 11 de agosto de 1971, referentes a profissionalizaçáo do ensino de $2^{\circ}$ grau. Brasília, 1982.

BRASIL. Lei no 8.948 de 08 de dezembro de 1994. Dispóe sobre a instituição do Sistema Nacional de Educação Tecnológica e dá outras providências. Brasília, 1994.

BRASIL. PORTARIA MINISTERIAL no 331 de 17 de junho de 1968. Altera a Lei n. ${ }^{\circ} 4.759$ e a escola industrial passou a denominar-se Escola Técnica Federal de Mato Grosso (ETFMT). Brasília, 1968.

BRASIL. Portaria No 862. Brasília, DOU, 19 de abril de 2017.

BRASIL. Portaria No 870. Brasília, DOU, 19 de abril de 2017.

BRASIL. Portaria No 871. Brasília, DOU, 20 de abril de 2017.

BRASIL. Relatório de Gestão do IFMT. Cuiabá, IFMT, 2017.

MATO GROSSO. Relatório da Gestão de Recursos Humanos. Cuiabá: GDRH CEFETMT, 2007

MATO GROSSO. Relatório da Gestáo de Recursos Humanos. Cuiabá: GDRH IFMT, 2008 a 2018.

\section{Jornais}

JORNAL ON LINE “OLHAR DIRETO”. Um ano de vida: o IFMT escreve sua história”. Edição do dia 29 de dezembro de 2009. Disponível em: http:// www.olhardireto.com.br/noticias/exibir.asp?id=72847\&noticia=um-ano-devida-o-ifmt-escreve-sua-historia. Acesso em: 13 de junho 2018. 


\section{Sistemas}

Assessoria de Comunicação do IFMT. 10/09/2014. Disponível em: http://bag. antigoportal.ifmt.edu.br/noticias/1009687/. Acesso em: 15 de junho 2018.

Assessoria de Comunicação do IFMT. 16/01/2018. Disponível em: http:// ifmt.edu.br/conteudo/noticia/professora-do-ifmt-campus-bela-vista-eselecionada-pelo-programa-de-bolsa-produtividade-em-pesquisa-do-cnpq/. Acesso em: 05 de junho 2018.

Sistema Unificado de Administraçáo Pública- SUAP,Junho de 2018. Disponível em: https://suap.ifmt.edu.br/accounts/login/?next=/. Acesso em: 08 de junho 2018. 


\section{SOBRE AUTORAS E AUTOR (ORGANIZADORAS E ORGANIZADOR)}

\section{Nilce Vieira Campos Ferreira}

Pós-Doutora e Doutora em Educação pela Universidade de Uberlândia (UFU). Professora Adjunta da Universidade Federal de Mato Grosso (UFMT)/ Instituto de Educação (IE)/DTFE/Cuiabá/MT e do Programa de Pós-graduação em Educação (PPGE)/Cuiabá/MT. Coordenadora da Rede de Pesquisa, Ensino e Extensão em Educação das Regióes Centro-Oeste e Norte do Brasil e América Latina - RECONAL-Edu; do Centro Memória Viva do Instituto de Educação da UFMT/Cuiabá (CMVIE); do Grupo de Pesquisa e Estudos em História da Educação, Instituições e Gênero (GPHEG). Conselheira da Sección de Educação da Latin American Studies Association - LASA: Educación y Políticas Educativas en América Latina. Desenvolve pesquisas com o apoio do Conselho Nacional de Desenvolvimento Científico e Tecnológico - CNPq. ORCID: https://orcid. org/0000-0002-9165-0011. E-mail: nilcevieiraufmt@gmail.com

\section{Neil Franco}

Doutor em Educação. Professor Adjunto de Departamento de Ginástica e Arte Corporal da Faculdade de Educação Física e Desportos, Universidade Federal de Juiz de Fora (UFJF). Professor do Programa de Pós-Graduação em Educação da UFJF. Coordenador do Grupo de Estudos e Pesquisa Corporeidades, Culturas e Diferença (GPCD). Coordenador dos projetos de Extensão: Pés de Valsa - danças de saláo UFJF, De Pernas Pro Ar - o universo gímnico em pauta e Ginástica Para Tod@s na Obra Social Santa Catarina. ORCID: https://orcid. org/0000-0002-1276-8901. E-mail: neilfranco010@hotmail.com

\section{Oresta López Pérez}

Professora-pesquisadora titular do El Colegio de San Luis - COLSAN, em San Luis Potosi, México. Membro do Sistema Nacional de Pesquisadores do México, nível II. Doutora em Ciências Sociais com especialização em História pelo CIESAS Occidente. Mestra em Antropologia Social pela Escola Nacional de Antropologia em História. Licenciada em História. Tem realizado atividades de pesquisa da educação e história da educação, para a Universidad Autónoma Chapingo; El Centro de Investigaciones y Estudios Avanzados del IPN (DIE-CINVESTAV; Subsecretaría 
de Educación Básica de la SEP; el Centro de Investigaciones Interdisciplinarias de Estudios de Género de la Universidad de Chile; assim como para Facultad de formación de Profesorado de la Universidad Autónoma de Madrid; fazendo parte do Centro de Investigaciones Multidisciplinarias de la Universidad Michoacana de San Nicolás de Hidalgo. Tem participado como conferencista convidada da Universidad Internacional Menéndez Pelayo en Tenerife España. Docente da Escuela Nacional de Antropología e na Universidad Michoacana. Docente em nível de Pós-Graduação da Universidad de Morelos; e no Instituto Superior de Ciencias de la Educación del Estado de México, e em nível de Doutorado na Universidad Pedagógica Unidad Ajusco e na docência de História do Colégio de San Luis, México, instituição onde também coordena o Programa de Pesquisa em História e o Seminário de História e Etnografia da Educação. Desde 2005 dirige o Seminário Permanente de Pesquisa: Educação, História e diversidade cultural no noroeste do México. Membro do Colegio de Etnólogos y Antropólogos e membro do Consejo Mexicano de Investigación Educativa e de vários comités científicos e editoriais vinculados a história da educação na América Latina. ORCID: https://orcid.org/0000-0003-0994-4545. E-mail: lopez.oresta@gmail.com

\section{SOBRE AUTORAS E AUTORES}

\section{Alceu Zoia}

Possui graduação em Filosofia pela Universidade Regional do Noroeste do Estado do Rio Grande do Sul (1990) e mestrado em Educação pela Universidade Federal de Mato Grosso (2000)e Doutorado em Educação pela Universidade Federal de Goiás(2009). Atualmente é professor adjunto da Universidade do Estado de Mato Grosso, atuando em diversos cursos e é professor e Vice Coordenador do Programa de Pós-Graduação - PPGEDU/ UNEMAT orientando na Linha de Pesquisa Educação e Diversidade. Membro do Corpo Editorial da Revista Educação, Cultura e Sociedade e dos Cadernos do CEACD. Tem experiência na área de Filosofia, com ênfase no Ensino de Filosofia, atuando principalmente nos seguintes temas: educação, filosofia, educação indígena e ensino. Participa do Grupo de Pesquisa Educação e Diversidade no contexto da Amazônia Legal Matogrossense e do MOPEC - Multiplos Olhares Sobre a Educação do Campo. Faço parte da Rede de Pesquisa ação Saberes Indígenas na Escola e da Rede Internacional de Pesquisadores sobre Povos Originários e Comunidades Tradicionais. ORCID: https://orcid.org/0000-0002-0512-9511. E-mail: alceuzoia@gmail.com 


\section{André Luís Monteiro Ferreira Lopes}

Possui graduação em História - Licenciatura e Bacharelado pela Universidade Federal de Uberlândia (2006). Especializaçáo em Gestão e funcionamento da escola (2014). Mestrado profissional em andamento em Ensino de História pela Universidade do Estado do Mato Grosso. Participa do Grupo de Pesquisa Linguagem, Artes, Cultura e Humanidades em Educação na Contemporaneidade - LINAHC, desde 2017. Atualmente é professor do Instituto Federal de Rondônia - IFRO em Colorado do Oeste/RO.Tem experiência na área de História, com ênfase em História do Brasil. Atuando no ensino de história do ensino fundamental, do ensino médio, na Educação para Jovens e Adultos (EJA) no ensino preparatório (concursos e pré vestibular). E-mail: andre.monteiro@ifro.edu.br

\section{Antônia Lúcia de Queiroz Tenório}

Mestrado em Ensino pelo Programa de Pós-Graduação Stricto Sensu em associação ampla entre a Universidade de Cuiabá-UNIC e o Instituto Federal de Educação, Ciência e Tecnologia do Estado de Mato Grosso- IFMT, linha de pesquisa - Ensino de Linguagens e seus códigos (2018). Especializaçáo em Ensino e Aprendizagem da Língua Francesa pela Universidade Federal de Mato Grosso (2001). Possui graduação em Letras Português/Francês pela Universidade Federal de Mato Grosso (1999). Tem experiência na área de Letras, com ênfase em Língua Portuguesa. E-mail: luciatenn@hotmail.com

\section{Carminha Aparecida Visquetti}

Doutoranda em Educação, no Programa de Pós-Graduação em Educação da Universidade Federal de Mato Grosso, na linha de pesquisa Cultura, Memória e Teorias em Educação. A pesquisadora tem graduação em Serviço Social pela Universidade Federal de Mato Grosso - UFMT (2007) com CRESS/MT n. ${ }^{\circ} 2222$, e graduação em Direito pela Universidade de Cuiabá (2010), com OAB/MT n. ${ }^{\circ}$ 14.978. Advogada com especialidade em Direito Constitucional (2013). Mestra em Educação pela Universidade Federal de Goiás - UFG, na linha de pesquisa Educação, Trabalho e Movimentos Sociais. Está como Assistente Social do Instituto Federal de Mato Grosso (IFMT) - Campus Várzea Grande e integrante do Grupo de Pesquisa em História da Educação, Instituiçôes e Gênero - GPHEG, da UFMT. ORCID ID: https://orcid. org/0000-0001-7395-7004. E-mail: carminhavisquetti@gmail.com 


\section{Cleicinéia Oliveira de Souza}

Doutoranda no Programa de Pós-Graduação em Educação da Universidade Federal de Mato Grosso, UFMT/IE, Campus Cuiabá. Bolsista da Coordenação de Aperfeiçoamento de Pessoal de Nível Superior - CAPES. Participa de pesquisas e estudos com financiamento do CNPq sobre História e Historiografia da Educação e das Instituiçóes Escolares na América Latina. Pesquisadora do Grupo de Pesquisa e Estudos em História da Educaçáo, Instituiçôes e Gênero - GPHEG. ORCID: https://orcid.org/0000-00033052-7754. E-mail: cleicineiao.souza@gmail.com

\section{Helen Arantes Martins}

Mestrado em Educação pela Universidade Estadual do Mato Grosso (UNEMAT)/ Bolsista CAPES. Possui Magistério (curso normal, título de profissional conferido:Professora de Educação Infantil e $1^{\mathrm{a}}$ a $4^{\mathrm{a}}$ séries do Ensino Fundamental), graduação em Ciências Contabéis pela Associação Vilhenense de Educação e Cultura de Rondônia (AVEC). Licenciatura em PEDAGOGIA pela Universidade Federal de Rondônia (UNIR)/Bolsista PiBiC. Licenciatura Plena em História (Fasa). Especialista em Supervisão, Orientação e Gestão Escolar com Ênfase em Psicologia Educaciona (FASA). Pesquisadora do Grupo de Pesquisa Estudos Pedagógicos (GEP) e Pesquisadora do Grupo de Pesquisa Educação e diversidade no contexto da Amazônia Legal Matogrossense. Participou no Programa de Bolsista do CNPq, por meio do (Programa Institucional de Bolsas de Iniciação Científica PIBIC/UNIR/ CNPq). Integrante do Grupo de Estudos sobre Crianças e Adolescentes em Situação de Risco. Membra do Grupo de Estudos Infâncias e Culturas Infantis. Ambos estão ligados ao Grupo de Pesquisa GEP/ UNIR-RO. E-mail: aranteshelen@hotmail.com

\section{Jefferson Bento de Moura}

Doutorando em Educação: Linha de Pesquisa de Educação em Ciências e Matemática da Universidade Federal de São Carlos - UFSCar. Professor do Instituto Federal de Educação, Ciências e Tecnologia do Mato Grosso Campus Juína. Coordenador do curso de Pós-Graduação Lato Sensu em Nível de Especialização em Ensino de Ciências da Natureza e Matemática do IFMT Campus Juína. E-mail: professor.je@gmail.com 


\section{Josemir Almeida Barros}

Pós-Doutor, Doutor e Mestre em Educação. Professor, Pesquisador e Extensionista do Departamento de Ciências da Educaçáo (DECED). Integrante do Programa de Pós-Graduação em Educação Escolar, Mestrado e Doutorado Profissional (PPGEE/Prof.) e do Programa de Pós-Graduação Stricto Sensu em Educação (PPGE/MEDUC), ambos da Universidade Federal de Rondônia (UNIR), Campus Porto Velho (PVH). Historiador e Pedagogo. Integrante do Grupo de Pesquisa Multidisciplinar em Educação e Infância (EDUCA) da UNIR, do Grupo de Pesquisa em História do Ensino Rural (GPHER) da UFU e do Grupo de Pesquisa e Estudos em História da Educação, Instituiçóes e Gênero (GPHEG) da UFMT. Vice Coordenador da Rede de Pesquisa, Ensino e Extensão em Educação das Regióes Centro-Oeste e Norte do Brasil e América Latina - RECONALEdu. Desenvolve pesquisas e estudos com financiamento do CNPq, CAPES e FAPERO sobre História e Historiografia da Educação com ênfase na escola rural, instituições escolares, políticas públicas, infâncias, entre outros. ORCID: https:// orcid.org/0000-0002-2687-6575. E-mail: josemirbh@gmail.com

\section{Kamilla Furtado Regatieri}

Formada em Psicologia pela Universidade Federal de Mato Grosso. Atua na área clínica desde a sua formação. Especialista em Terapia Cognitiva e com curso Profissionalizante de Transtornos do Impulso pela Universidade de São Paulo ( USP). E-mail: kahmilinha_@hotmail.com

\section{Márcia Jovani de Oliveira}

Supervisora Pedagógica do Instituto Federal de Educação, Ciência e Tecnologia - IFRO Campus Colorado do Oeste - RO. Doutoranda e Mestra em Educação Escolar pelo Programa de Pós-Graduação em Educação Escolar, Mestrado e Doutorado Profissional da Universidade Federal de Rondônia (PPGEE/ Prof./UNIR). Possui Especialização em Gestão, Orientação e Supervisão com Ênfase em Psicologia Educacional pela Faculdade de Rolim de Moura (2012); Graduação em Pedagogia pela Faculdade de Educação de Colorado do Oeste (2004), Graduação em Ciências Contábeis pela Universidade do Tocantins (2012); Técnica em agropecuária formada pela Escola Agrotécnica Federal de Colorado do Oeste (1997). É pesquisadora na área da Educação, no campo da História e Historiografia da Educação, com ênfase na formação de professores, 
práticas pedagógicas, Educação Rural, professores leigos, migração e colonização de Rondônia. Integra o Grupo de Pesquisa Ciência de Alimentos na área de projetos integradores no ensino técnico e tecnológico no IFRO Campus Colorado do Oeste e o Grupo de Pesquisa Multidisciplinar em Educação e Infância (EDUCA) da Universidade Federal de Rondônia (UNIR). ORCID: https://orcid.org/0000-0002-1568-0462. E-mail: marcia.nunes@ifro.edu.br

\section{Maria do Socorro de Souza Araújo}

Possui graduação em Medicina Veterinária pela Fundação Francisco Mascarenhas, Patos/PB (1979), graduação em Licenciatura e Bacharelado em História pela Universidade Federal de Mato Grosso (1993), Mestrado em História pela Universidade Federal de Mato Grosso (2002) e Doutorado em História Cultural, na UNICAMP (2013). Atualmente é professora titular da Universidade do Estado de Mato Grosso, com lotação no Departamento de História, do Campus Universitário "Jane Vanini” - UNEMAT/Cáceres. Tem experiência na área de História, com ênfase em História do Brasil, atuando principalmente nas seguintes áreas: História Cultural e História Política. Tem experiência com pesquisa com fontes orais e integra o Núcleo de Estudos Literários/NEL do Departamento de Letras, UNEMAT/Cáceres/MT. Faz parte do Grupo de Pesquisa Fronteira Oeste: Poder, Economia e Sociedade, vinculado ao Departamento de História do Campus de Cáceres/MT. E-mail: socorroaraujo@unemat.br

\section{Maria Emília de Castro Rodrigues}

Doutora em Educação pela Universidade Federal de Goiás, graduada em pedagogia pela mesma universidade. Atualmente é professora adjunta da Universidade Federal de Goiás e tem experiência na área da Educação, com ênfase em Prática Docente e Educação de Jovens e Adultos, atuando principalmente em temas como: didática, estágio, educação de Jovens, educação popular e formação inicial e continuada de professores. E-mail: me.castrorodrigues@gmail.com

\section{Nathalia Martins Luna}

Graduação em História na Universidade Federal de Mato Grosso - UFMT (em andamento). Bolsista de Iniciação Científica (CNPq/UFMT). Atuou como Extensionista PBEXT AÇÓEES 2018 no Centro Memória Viva do Instituto de Educação da UFMT. E-mail: nnluna234@outlook.com 


\section{Qelli Viviane Dias Rocha}

Doutoranda em Serviço Social pelo Programa Interinstitucional UNB/UFMT. Pesquisa relaçóes de gênero, Identidade e Sexualidades. Possui Graduação em Serviço Social pela Universidade Estadual Paulista Júlio de Mesquita Filho (2006). Atualmente é professora Assistente do Departamento de Serviço Social da Universidade Federal de Mato Grosso, participa como pesquisadora do Núcleo de estudos e pesquisa sobre a organizaçáo da mulher e relaçóes de Gênero (NUEPOM- UFMT), coordena o grupo de Estudos sobre sexualidade e identidade de gênero do NUEPOM. E-mail: qelliviviane@yahoo.com.br

\section{Roger dos Santos Lima}

Mestre em Educação pelo Programa de Pós-Graduação em Educação da Fundação Universidade Federal de Rondônia - PPGE/UNIR (2019). Possui graduação em Pedagogia pela UNIR (2017). Integra o Grupo de Pesquisa Multidisciplinar em Educação e Infância - EDUCA/UNIR. Atua e desenvolve pesquisas nos seguintes campos: Escola Rural, História da Educação, Educação Infantil, Políticas Públicas e Processos Formativos de Professoras e Professores Leigos. Em suas atividades profissionais interagiu com vários colaboradores em co-autorias de produtos científicos. Desenvolve pesquisas com financiamento do CNPq e FAPERO. ORCID: https://orcid.org/0000-0002-8607-104X. E-mail: roger.sntm@gmail.com

\section{Romilson Brito de Azevedo}

Mestrando do Programa de Pós-Graduação em Ensino de Ciências e Humanidades pelo Instituto de Educação, Agricultura e Ambiente - IEAA/ UFAM (2018). Graduado em Pedagogia pela Universidade Federal do Amazonas-UFAM (2010). Pedagogo da Educação Básica-SEMED/HumaitáAM (2012). Colaborador no Grupo de Investigação Sobre Relação Educativa e Aprendizagem-LAPESAM-Laboratório de Avaliação Psicopedagógica, Educacional, Histórico, Cultural e Social da Amazônia no IEAA/UFAM. E-mail: romilson.azvdo16@gmail.com

\section{Rosangela Queiroz Garcia Leite Nogueira}

Possui Mestrado Acadêmico em Ensino - UNIC/IFMT (2019). Graduação em Pedagogia - UNIVAG (2004), Graduada em Direito (2008), Pós Graduação lato 
sensu em Função Social e Prática do Direto (2008), Pós Graduação lato sensu em Psicopedagogia (2013), Pós Graduação lato sensu em Gestão Pública (2014), Professora - Educação Básica/SEDUC/MT. E-mail: socorroaraujo@unemat.br

\section{Rosemar Eurico Coenga}

Possui graduação em Letras Habilitação Português Francês pela Universidade Federal de Mato Grosso (1999), Mestrado em Educação pela Universidade Federal de Mato Grosso (2003) e Doutorado em Programa de Pós-Graduação em Literatura pela Universidade de Brasília (2011). Pós-Doutorando pela Universidade de São Paulo. Tem experiência na área de Letras - Língua Portuguesa e Literatura Brasileira. E-mail: rcoenga@gmail.com

\section{Sandra Jung de Mattos}

Mestra em Educação pelo Programa de Pós-graduação em Educação da Universidade Federal de Mato Grosso. Especialização em Educação do Campo pela Universidade Federal do Paraná. Graduação em Pedagogia, Habilitação em Administraçáo Escolar e Séries Iniciais pela Universidade Estadual do Centro-Oeste. Atuou como professora na Faculdade de Ciências Contábeis e Administraçáo do Vale do Juruena - AJES no curso de Pedagogia, professora e coordenadora da Área de Ciências Humanas do Centro de Educação de Jovens e Adultos Alternativo - CEJA e assessora pedagógica da Unidade do Senai Juína. Foi Supervisora de Extensão e atualmente Coordenadora de Extensão da Universidade Federal do Mato Grosso. Participa no Grupo de Pesquisa de Estudos em História da Educação, Instituiçôes e Relações de Gênero - GPHEG, e pesquisa as temáticas de Educação Feminina, História das Mulheres e Extensão Universitária. E-mail: sandrajmattos@gmail.com

\section{Silvia Maria dos Santos Stering}

Doutora e pós-doutora em Educação. Possui graduação em Pedagogia pela Universidade Federal de Mato Grosso (1996). Mestrado em Movimentos Sociais e Educação Popular também pela UFMT (2008). Tem experiência na área de Educação, atuando principalmente nos seguintes temas: Educação Popular, Movimentos Sociais em Educaçáo, Processos Instituintes, Institucionalização dos Movimentos Sociais, PROEJA, Educação Profissional e Tecnológica, Educação ao Longo da Vida e Políticas Públicas em Educação. 
Faz parte do Grupo de Investigação “ Políticas, Governação e Administração da Educação”, RG-NORTE-1661-109 da UMinho Campus Gualtar, da Rede de Pesquisa, Ensino e Extensão em Educação nas regiôes Centro-Oeste e Norte do Brasil e na América Latina - RECONAL-Edu, e do Grupo de Pesquisa e Estudos em História da Educação, Instituiçôes e Gênero - GPHEG. Pedagoga no Instituto Federal de Educação, Ciência e Tecnologia de Mato GrossoIFMT, Pró Reitoria de Ensino. E-mail: silvia.stering@ifmt.edu.br

\section{Tatiane Lebre Dias}

Psicóloga (Universidade Católica Dom Bosco), Mestre em Educação pela Universidade Federal de Mato Grosso (UFMT), Doutora em Psicologia (Universidade Federal do Espírito Santo). Docente do Departamento de Psicologia e dos Programas de Pós-Graduação em Psicologia (UFMT) e Educação (UFMT). Pesquisadora da Linha de Pesquisa Culturas Escolas e Linguagens e do Laboratório de Estudos e Pesquisas em Avaliaçáo Psicológica. E-mail: tatianelebre@gmail.com

\section{Valmir Flores Pinto}

Doutorado em Educação. Professor na Universidade Federal do Amazonas - UFAM. Coordenador do Programa de Pós-Graduação em Ensino de Ciências e Humanidade - Mestrado Acadêmico; Vice-Coordenador da Revista de Ensino de Ciências e Humanidades (RECH - http:// www.periodicos.ufam.edu.br/rech/issue/current. Membro do Núcleo de Estudos e Pesquisas em Direitos e Humanos e Educação (UFAM Humaitá); Membro do Grupo Multidisciplinar de Pesquisa em Educação, Psicopedagogia e Psicologia Escolar - UFAM/CNPq; Membro da Comissão de Avaliação e Progressão do IEAA/UFAM; Professor e Orientador no PPGECH/IEAA/UFAM; Professor de Filosofia na Graduação do IEAA/ UFAM. E-mail: valmirfloresp@gmail.com 
O objetivo deste livro é reunir trabalhos de pesquisadoras e pesquisadores das regiöes Centro-Oeste e Norte brasileiras, com o intuito de explorar pesquisas no domínio da Rede de Pesquisá, Ensino e Extensão nas Regiões Centro-Oeste e Norte do Brasil e América Latina - RECONAL-Edu, uma rede de pesquisa que congrega pesquisadoras, pesquisadores e extensionistas com objetivo de ampliar o campo de estudos entre essas regiões articuladas às pesquisas realizádas na América Latina. Nos textos são apresentadas investigaçóes que nos permitem conhecer, de forma densa, os estudos que são desenvolvidos nessas regiões. Autoras e autores cuidadosamente nos afastam do esquecimento tâo comuns nos dias de hoje, aproximando-nos de memórias, histórias, práticas e saberes, lançando para além de si, de suas redes e grupos, vínculos que se articulam rumo uma educação coletiva que reeläbora e rememora a educação que se faz nas regiões Centro-Oeste e Norte brasileiras.

Nilce Vieira Campos Ferreira

Neil Franco

Oresta López Pérez

(Organizadores)
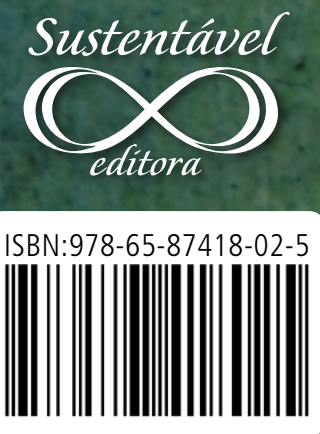
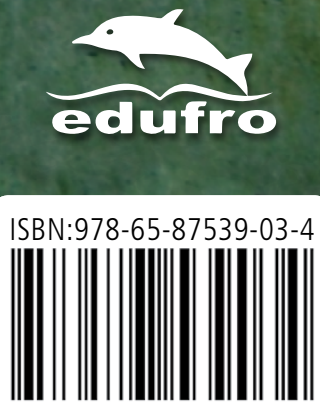

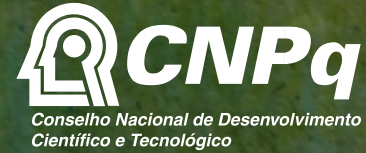

Cientifico e Tecnológico
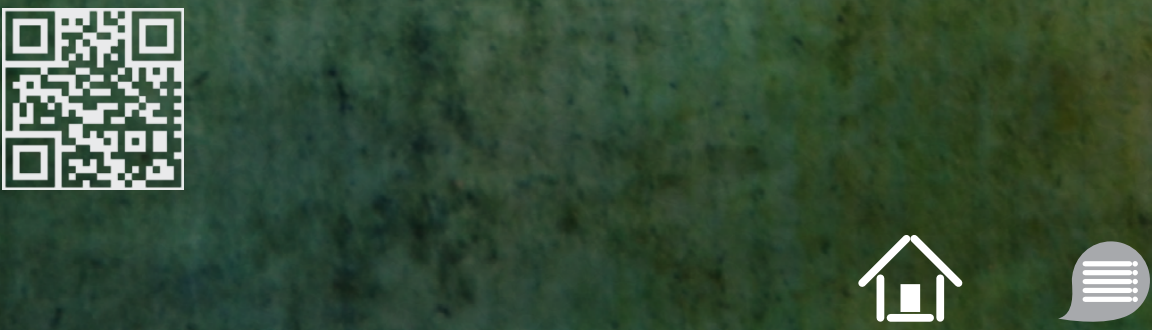